Historic, Archive Document

Do not assume content reflects current scientific knowledge, policies, or practices. 



\section{SuperiorSeeds Grown at Elm ValleySeed Gardens ZACK DAVIS CO., DELAWARE, OHIO, U. S. A.}

\section{HOW TO ORDER.}

Always use the Order Blank and Envelope sent with the catalogue when it is possible. Write plainly, keep a copy of your order, and be sure to sign your Name, Post Ofice, County and State every time you write to us. Extra envelopes and order blanks are sent on application, also additional catalogues if desired.

BE FREE TO WRITE TO US for any information pertaining to our business and not found in this catalogue. Write on a separate sheet of paper from your order.

\section{HOW TO SEND MONEY.}

Cash should always accompany the order. Remittances may be made at our risk by any of the following methods: (First and best) Post Office Order. (2d) Draft on New York. (3d) Express Co.'s Money Order. (4th) Cash by Express in amounts not less than $\$ 5.00$. (5th) Registered Letter. When money cannot be sent by either of the first four methods, it may be enclosed in a Registered Letter. The rates for post office orders and express money orders are now so low that this is the best way to remit where they can be obtained. We will bear the expenses of sending money in either of above ways when order amounts to $\$ 1$ or over.

In ordering sweet corn, peas and beans in pound lots or over please remember that the prices we quote do not include the parcel post from Delaware to you. You can figure that from the parcel post information on the order blank, or your rural free delivery carrier or postmaster will tell you. This postage must in all cases be included with the orders on s weet corn, peas and beans in pound lots or over.

\section{SFND ORDERS FARIY.}

It is our aim to fill all orders, when possible, the day they are received; but it sometimes happens during the rush season that this is impossible to do, and for that reason all orders arc entered as soon as received and filled in rotation, the small orders receiving the same careful attention as the larger ones. Therefore we would advise our friends to send in their orders as soon as they receive this catalogue and thus avoid any possibility of delay when ready to plant. $\Lambda$ great many orders for seeds also include tender bulbs, plants and potatoes, and when the weather permits we try to send all these at one time, but often it is dangerous to do so, in which case we will forward the seeds and hold the balance of the order until danger of freezing is past.

TERISS CASE.

No goods sent C. O. D. unless cash to the amount of one-fourth the order accompanies the same.

\section{SHIPPING DIRECTIONS.}

When goods are to be shipped by Freight or Express give plain shipping directions, otherwise we use our best judgment.

\section{SHIPPING FACIIITIFS.}

Delaware has the Big Four, Penn., and $H$. $V$. railroads, and the American, Adams and Wells Fargo \& Co. Express Companies. Thus we are able to procure the lowest rates to all parts of the country by freight or express.

\section{IARGE ORDERS.}

Any dealer, market gardener, institution, or individual wishing seeds in large quantities are requested to mail us a list of what they want, and we will promptly return it to them with the very lowest prices marked. A letter of inquiry may save you dollars if you want to buy in quantity.

\section{SMAII ORDERS.}

If you only want a single packet, do not hesitate to order it. We take as much pains with small orders as large ones.

\section{WE URGE}

Customers to inform us promptly on the arrival of orders, if not in good condition, well packed and filled exactly as ordered; also to report (after growth) the result, more especially if anything proves otherwise than expected. We aim to make friends of our customers, and mail orders receive the same careful attention that customers do over our counters.

\section{HOW WF WARRANT.}

We thoroughly test all our seeds before sending them out, and do not send out any that do not prove good in every respect. We believe our seed excels all others. When it is considered how many disadvantages some seeds have in making a perfect crop-such as sowing too deep or too shallow, too wet or too dry, insects, etc.,-our customers will see at once that it is unreasonable to expect any one to guarantee a kerfect crop. Therefore, while we exercise the greatest care to have all seeds pure, reliable and true to name, we give no warrant expressed or implied, and will not be in any way responsible for the crop. If the purchaser does not accept the seed on these terms, they are at once to be returned. Furthermore, we are so confident that our seeds are pure, reliable and true to name that should any not prove thus we will refill all orders for vegetable or flower seeds free of charge.

\section{EXTRA SEED FREF.}

On all orders for Flower or Vegetable Seeds in Packets or Ounces the purchasers may select seeds to the value of $\$ 1.25$ for each $\$ 1.00$ sent us. Thus, any one sending us $\$ 1.00$ can select seeds in packets or ounce amounting to $\$ 1.25$; or for $\$ 2.00$ seeds in packets or ounces to the value of $\$ 2.50$, and so on. This discount applies only on seeds in packets and ounces, and does not refer to seeds offered by weight (quarter-pounds, etc.) or measure (pint, quart, etc.), nor to potatoes, onion sets, bulbs or plants.

Please do not include any of these wher taking advantage of our Packet Discount.

Make all Money Orders payable to 
Please use this Order Sheet for your order.

\section{ELM VALLEY SEED GARDENS ZACK DAVIS COMPANY, Proprietors \\ DELAWARE, OHIO}

\section{WRITE YOUR NAME AND ADDRESS PLAINLY}

Name

Post Office

County

State

R. R. Station or Express Office (If different from Post Office)

Shall we for- $\}$ Mail, Freight $\}$ ward by $\}$ or Express $\}$

When sent by FREIGHT, EXPRESS or PARCEL POST the transportation charges are always to be paid by the purchaser.

Do you grow vegetables for market? Ans. Yes or No
Date

Amount Enclosed \$

Do NOT write in this space

Rec'd

M. O. Dft. Cash. Stps. Chk.

Filled by

Shipped by

O. K. $d$ When ordering aend us the addresses of a few of your friends who make darden (nome other)
and wo will sead you froe some cholce trial seeds for your trouble.

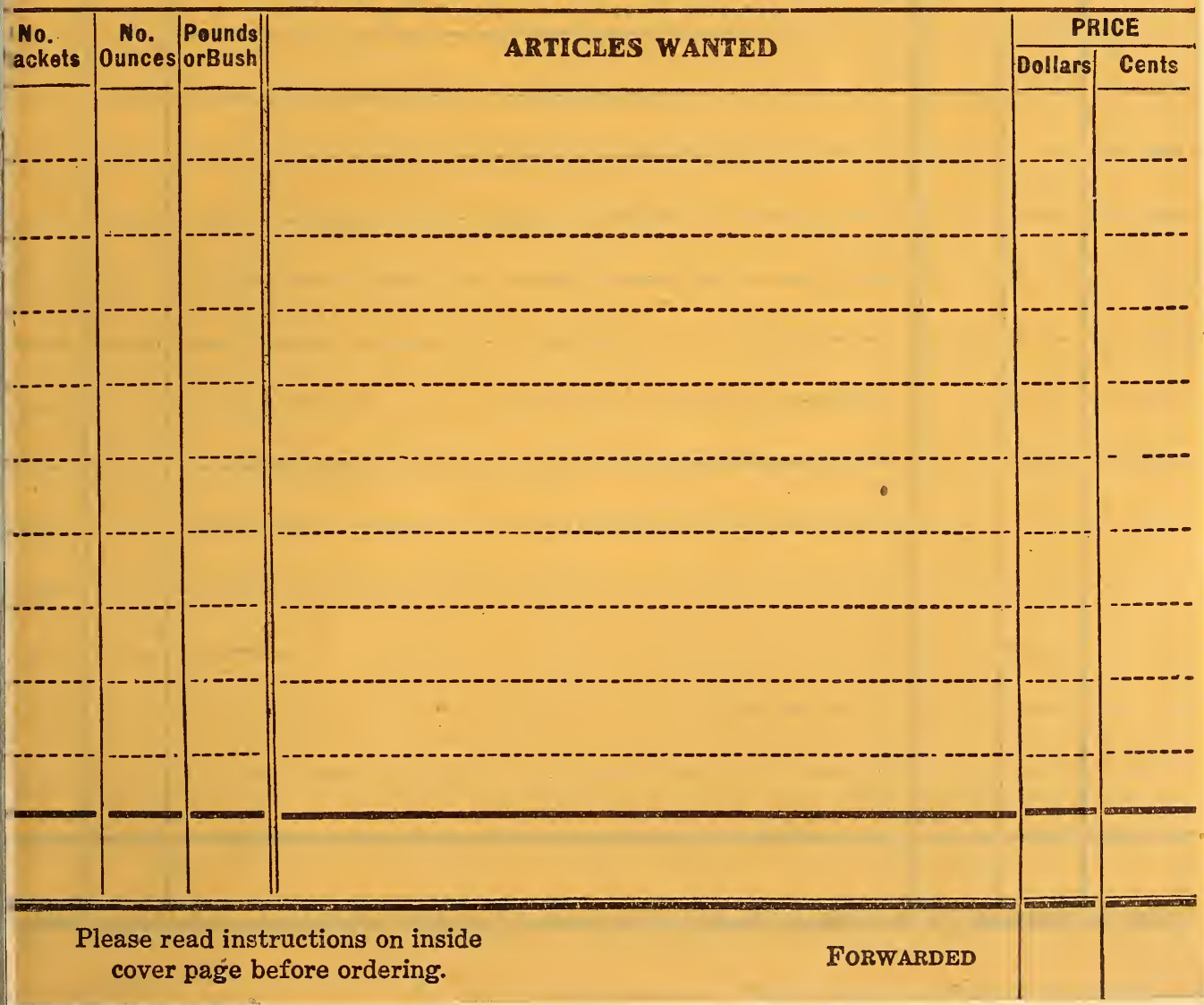




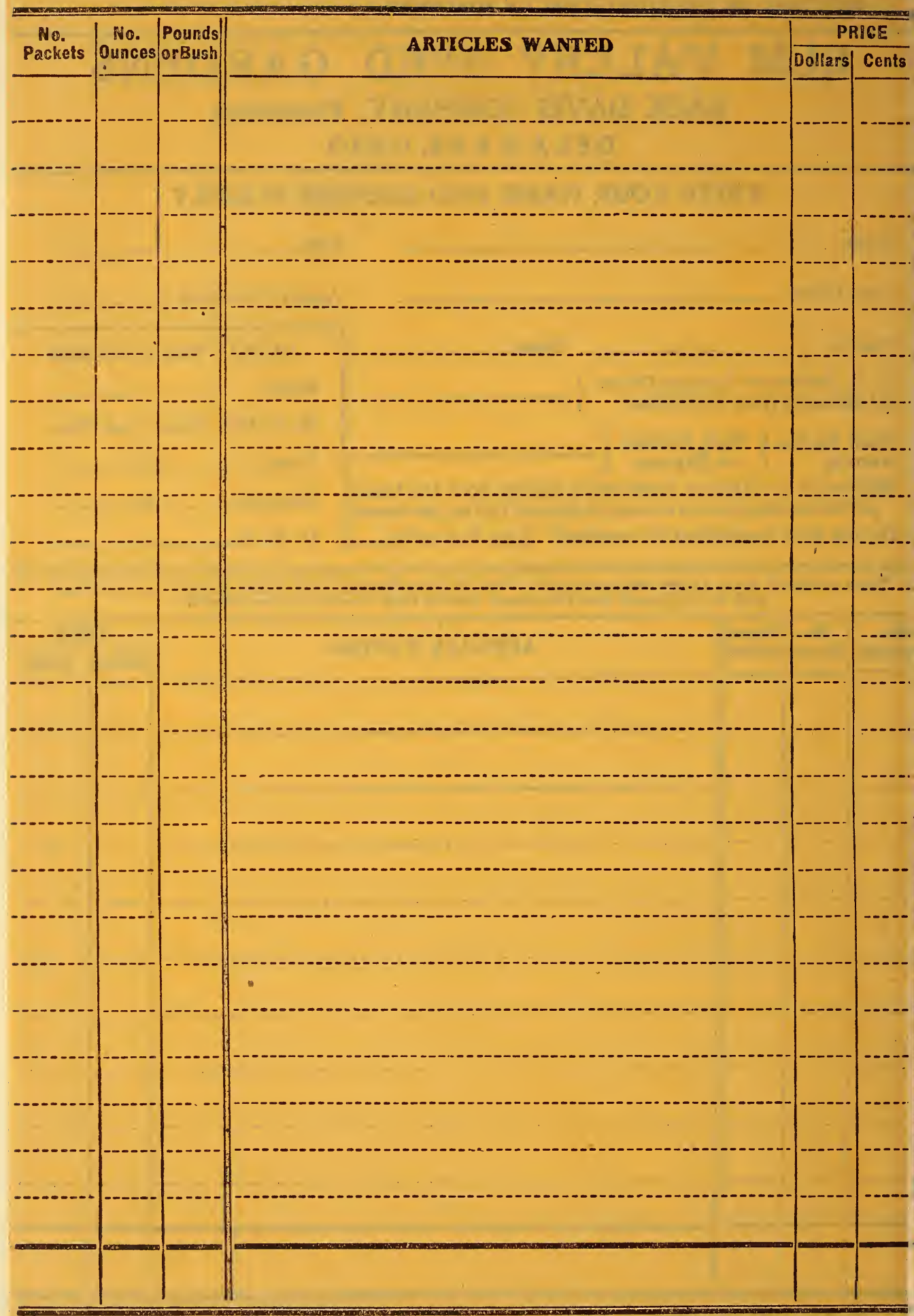




\section{TO OUR FRIENDS}

To the old friends who have for years bought their seeds of us perhaps we can give 1 no new message this year, except that we have added a number of improvements in

the way of handling our goods, so that they will arrive better than ever. We take this page to thank them for the patronage that in more than twenty years has enabled us to build up a good sized business, founded, we are glad to think, upon the confidence of ou: neighbors and friends, including those known to us only by the letters that have passed between us. We are grateful for the patronage of the past years, and we are honestly and tirelessly striving to deserve more.

That we are succeeding is proved by the large number of new friends every year adds. Perhaps we need not tell our old customers that Davis' seed are really superior seeds of quality. Because they are so these old customers have remained with us for twenty years. But to the new friends we would say that back of our steady increase in business lies the determination to always give the best. What we offer is tested as to purity and vitality, and we are constantly extending our lines to take in the proven best, remarkable for highest yields and marketing qualities.

Our Garden and Flower seeds are grown on contract especially for us by competent and reliable growers in various sections best suited for their production. We believe, from a practical experience in the seed business in all its branches for twenty-five years, we are as thoroughly posted and competent to handle the business as any one in the trade.

We want every customer to be a friend. Our interest does not cease when you receive the seed sent you. If we, from our long experience, can help you in any way, remember we want to serve you and write us freely.

May we urge upon you that you send in your orders early? Perhaps we will have enough of everything to last the whole season out, but it may be we will be short before all orders reach us. As we fill all orders the day they reach us, usually, the late comers may be disappointed. So we urge you to send in your orders as early as possible.

Thanking all our old friends and assuring them and the new ones that we will try under all circumstances to please you, we remain as ever,

Very cordially yours,

ZACK DAVIS CO.

\section{Using Parcel Post}

The parcel post in many cases affords a more convenient way of getting seeds to our customers than express. We will be pleased to ship by parcel post whenever instructed, but on some of the more bulky articles you must send us the postage necessary with your order. This applies especially to sweet corn, peas and beans in pound lots or over.

Your postmaster or your rural free delivery carrier can tell you what the amount will be. For your convenience we append a table showing the rates in the various zones. The limit of weight for the first and second zones is fifty pounds, and for all other zones twenty pounds. If weight exceeds this we can pack in two or three parcels.

If you want to be absolutely sure of the arrival of your order you may have it insured via parcel post. The rates are five cents for each package up to $\$ 25$ in value, and 10 cents for each package between $\$ 25$ and $\$ 50$ in value. If you desire the packages insured add the insurance fee to the order, and be sure to tell us it is for that purpose.

\section{DOMESTIC PARCEL POST RATES}

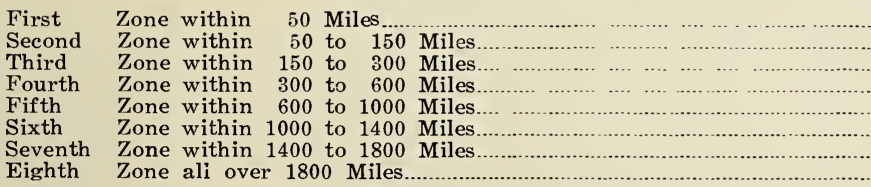

First
Pound
(over 8 oz.
rates $1 \mathrm{lb}$ )
$5 \mathrm{c}$
$5 \mathrm{c}$
$6 \mathrm{c}$
$7 \mathrm{c}$
$8 \mathrm{c}$
$9 \mathrm{c}$
$11 \mathrm{c}$
$12 \mathrm{c}$

Each Additional Pound or fraction.

$1 \mathrm{c}$
$1 \mathrm{c}$
$2 \mathrm{c}$
$4 \mathrm{c}$
$6 \mathrm{c}$
$8 \mathrm{c}$
$10 \mathrm{c}$
$12 \mathrm{c}$

THIS CATALOGUE will be mailed free to anyone who is directly interested in gardening and farming. Our customers will confer a favor on us by sending a list of names of their friends and neighbors who would be interested in receiving a catalogue. 


\section{ASPARAGUS}

\section{COLUMBIAN MAMMOTH WHITE}

A fine new variety, wonderfully productive and hardy. The shoots remain white as long as fit for use. This sort has been thoroughly tested, and is considered the best by all growers. Pkt. 5c; oz., 10c; $1 / 41$ lb., 20c; lb., 50c. PALMETTO

This is the finest variaty grown. Wonderfully productive, tender and rich. When cooked is free from woody fibre. Pkt., 5c; oz., 10c; 1/4 lb., 20c; lb., 50 c.

\section{ASPARAGUS ROOTS}

Strong, two-year-old plants of either above varieties by mail, postpaid, $\$ 1.00$ per $100 ;$ by express, 75 c per $100 ; \$ 5.00$ per 1,000 . 500 roots furnished at 1,000 rate.

\section{BEANS}

We do not pay the parcel post on pound lots or over of beans.

One quart to 100 feet of drill. One bushel per acre.

\section{WAX PODDED VARIETIES}

\section{NEW DAVIS WAX}

The best Flat Podded Wax Bean for Market. Extensive trials have proven this bean the largest cropper, the handsomest pod, the best shipping and market bean in cultivation.

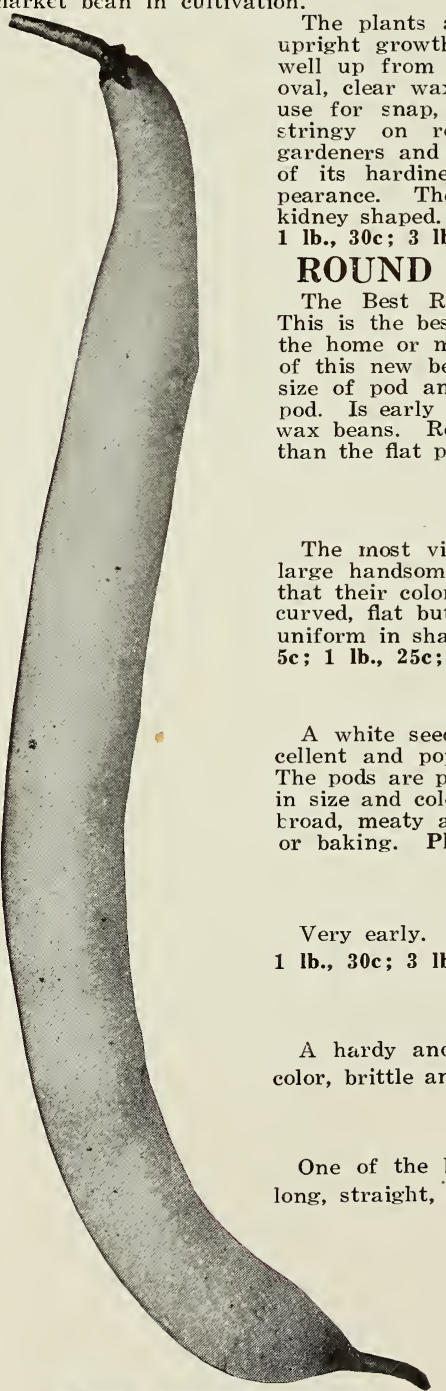

Round Podded Kidney Wax

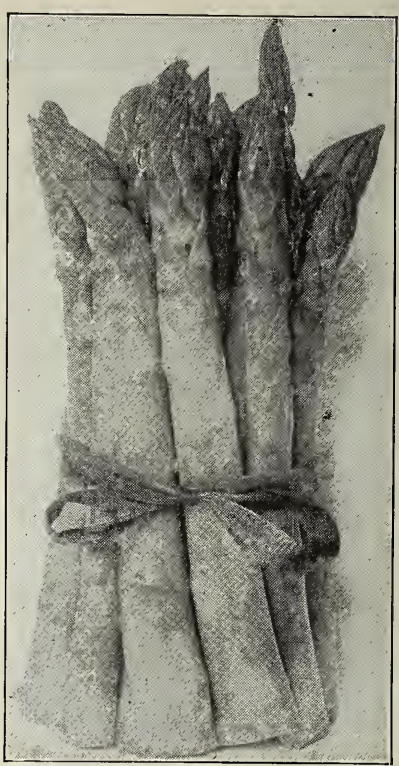

Columbia Mammoch This is the best Wax Bean yet introduced for either the home or market garden. Market gardeners will appreciate the importance to them 列 size of pod and productiveness; has a beautiful waxy golden yellow color, round, neat pod. Is early and the pod is straight, not curved like so many of the other round-podded their freshness longer

\section{HODSON WAX}

most vigorous of any dwarf wax podded bean yet introduced and the yield of The handsome pods is enormous. Its dense foliage so completely protects the pods that their color is an unusually clear creamy white. Pods very long, straight or slightly , flat but fleshy, quite stringless and of very good quality. Seed long, cylindrical, in shape; color light yellowish-brown, heavily splashed with dull crimson. Pkt.,

\section{MICHIGAN WHITE WAX}

the seeded Golden Wax Bean kut in several features it is superior to this exA popclar varicty. The plant is more vigorous and foliage a little heavier. he pods are produced in greater abundance than the Golden Wax and are very uniform color, which is a very attractive light golden yellow; pods are comparatively meaty and of fine quality. It is also a fine bean when dried and used for soup kt., 5c; 1 lb., 30c; 3 lb., 75c; 15 lb., \$3.00.

\section{PROLIFIC GERMAN BLACK WAX}

Very early. Pods are large, of a golden wax color and of the best quality. Pkt., 5c; 1 lb., 30c; 3 lb., 75c; 15 lb., \$3.00.

\section{WARDWELL'S DWARF KIDNEY WAX}

A hardy and productive variety. Pods long, broad. flat and delicate, waxy yellow color, brittle and entirely stringless. Pkt., 5c; 1 lb., 30c; 3 lb., 75c; 15 lb., \$3.00.

\section{IMPROVED GOLDEN WAX}

One of the best strains of Golden Wax. Hardy, prolific, of the best quality; pods long, straight, thick, and vines very erect. Pkt., 5c; 1 lb., 30c; 3 lb., 75c; 15 lb., \$3.00.

\section{Testimonials}

V. O. Bowman, Oakland, Md., writes: I received the seeds which I ordered from you. They arrived in good condition and $I$ am very well pleased with them. I hope they are free from foul seeds as I have always found the seeds I have purchased from you in my previous orders. I thank you for prompt attention. 


\section{GREEN PODDED BUSH BEANS}

\section{NEW BOUNTIFUL}

This is the best flat podded green bush bean on the market. Coming into usable size extra early, it keeps on bearing until frost. It is a vigorous grower, having dark green foliage. The pods are large, flat and extra long, very uniform in size and shape, solid, meaty, stringless and of delicate flavor. It is fairly springing into popular use simply meaty, stringless anirable for both home and market. Pkt., 5c; 1 lb., 25c; 3 lb., 60c; 15 on its m., \$2.00.

\section{BURPEE'S STRINGLESS GREEN POD}

A new green-podded variety that is becoming very popular. The finely shaped long green pods are absolutely stringless, and when we add that the pods are ready for market green pods are absoluter the Early Red Valentine, we are sure that it will supply a long felt want. Pkt., 5c; 1 lb., 30c; 3 lb., 75c; 15 lb., $\$ 2.50 ; 60$ lb., $\$ 9.75$.

\section{IMPROVED RED VALENTINE}

A well known very early sort which has been extensively planted for years and there is hardly any variety superior to this, nor one that is more popular for general market or family use. Our strain is very select stock. Pods of medium length about 41/2 inches long family use. Our strain is ver, cylindrical, with crease in the back, very fleshy, crisp and tender. Vines medium to large, erect, with dark green leaves. Seed long, purplish pink, splashed with light buff. Pkt., 5c; 1 lb., 35c; 3 lb., 75c; 15 lb., \$2.50.

\section{NEW GIANT STRINGLESS VALENTINE}

The gardener's money maker. The old fashioned early Red Valentine has long been considered the best of its class, but in this new variety we have something superior in considered the best of its class, it ready for market with a more prolific crop a full week earlier; the pods are a third larger, averaging five to six inches in length. They are very meaty, being are a third larger, averaging five to six inches in length. They are very meaty, being we have sent this bean we have heard nothing but recommendations, and we predict that it will shortly supersede all others of its color. Do not fail to include this bean in your order. Pkt., 5c; 1 lb., 30c; 3 lb., 75c; 15 lb., \$2.50.

\section{EARLY ROUND YELLOW SIX WEEKS}

A very early and popular market variety. Pkt., 5c; 1 lb., 25c; 3 lb., 60c; 15 lb., \$2.00. REFUGEE OR 1000 TO 1

A standard green podded variety. Pkt., 5c; 1 lb., 25c; 3 lb., 60; 15 lb., \$2.00.

\section{DWARF HORTICULTURAL}

Known also as Cranberry, Quail's Head, etc. A very fine variety both as a snap or a shell bean. Pods are large and showy, green, spotted and blotched reddish brown. Pkt., 5c; 1 lb., 30c; 3 lb., 75c; 15 lb., $\$ 2.25$.

\section{DWARF RED KIDNEY}

Similar to White Kidney but dark pink color. Very salable. Pkt., 5c; 1 lb., 20c; 3 lb., $50 \mathrm{c} ; 15$ lb., $\$ 1.75 ; 60$ lb., $\$ 6.75$.

\section{WHITE KIDNEY}

Unexcelled, either for shelling when green or for baking when dry. Very productive. Pkt., 5c; 1 lb., 20c; 3 lb., 50c; 15 lb., $\$ 1.75 ; 60$ lb., $\$ 6.75$.

\section{WHITE MARROWFAT}

A standard and productive field variety. Pkt., 5c; 1 lb., 20c; 3 lb., 50c; 15 lb., \$1.50; $60 \mathrm{lb}$., $\$ 5.75$.

\section{NAVY OR BOSTON PEA} .

The best known field variety. Pkt., 5c; 1 lb., 20c; 3 lb., 50c; $15 \mathrm{lb.,} \$ 1.50 ; 60 \mathrm{lb}$., $\$ 5.50$.

\section{BROAD WINDSOR}

An English variety. Large and best of its class. Pkt., 5c; 1 lb., 25c; 3 lb., 60c.

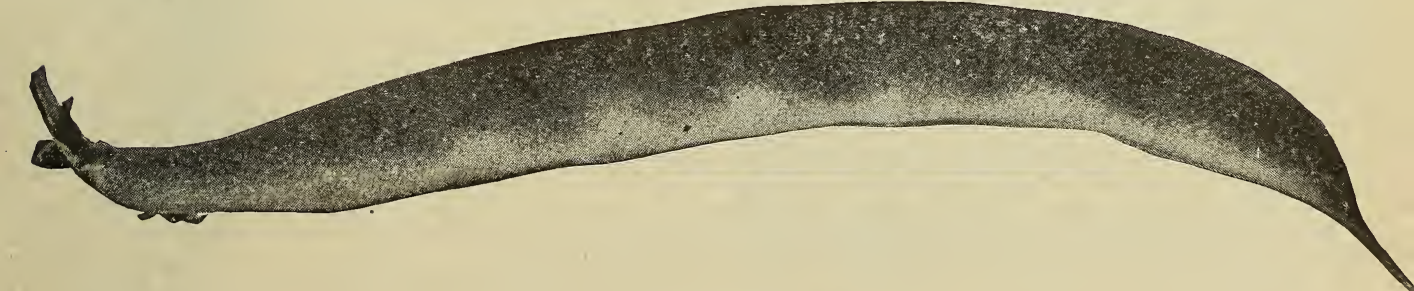




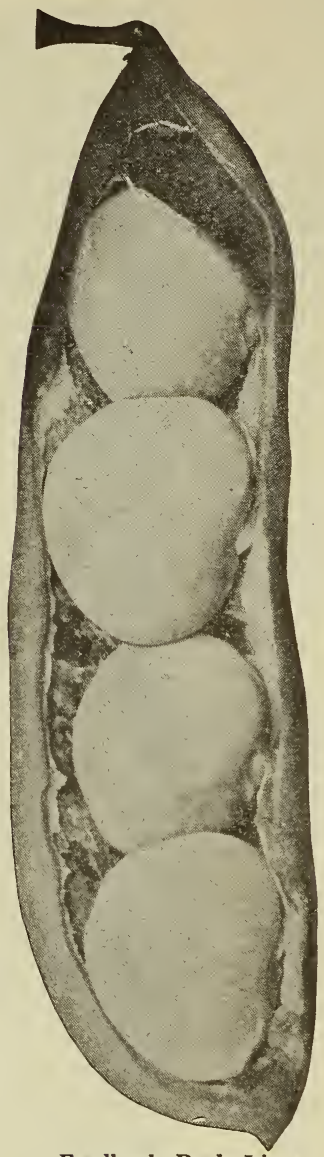

Fordhook Bush Lima

\section{DWARF OF BUSH LIIIA}

\section{FORDHOOK BUSH LIMA}

(See Illustration)

This variety is entirely distinct in habit of growth. The stiffly erect bushes branch freely and bear tremendous crops. It is ready for use as early as the popular Burpee's Bush Lima, but the beans are much plumper and remain green much longer. It is an exceedingly handsome bean and therefore a ready seller. The shelled beans are very fat, are closely packed in the pods, which shell very easily. Pods are borne in clusters from four to six, average 4 to 5 inches long and contain usually 4 tender and juicy beans, which are of a delicious flavor. 1 lb., 30c; 3 lb., 75c; 15 lb., $\$ 3.00$.

\section{BURPEE'S IMPROVED BUSH LIMA}

This new variety may be regarded as the largest and the best of the large seeded Bush Lima Beans. The vines of these beans average larger in size than the New Wonder,. and produce a considerably larger crop. The pods are larger than the older varieties and contain beans which are proportionately thicker and larger than the older varieties. The quality is excellent. In season a week earlier than the New Wonder or Burpee's Bush. Lima. 1 lb., 30c; 3 lb., 75c; 15 lb., $\$ 3.00$.

\section{NEW WONDER BUSH LIMA}

The highest expert authorities on Garden Beans have decided this to be the best of all the large seeded Bush Limas for general purpose. The plants are large, compact, medium season, long bearing and very prolific. The shell pods are green, of smooth surface, slightly curved, uniform and large, usually containing three seeds. This originated from one of the first types of Bush Limas, but is earlier and more compact in habit, and with less tendency to make runners. 1 lb., 30c; 3 lb., 75c; 15 lb., $\$ 2.50$.

\section{BURPEE'S BUSH LIMA}

The bush character is thoroughly established. Not one plant in a hundred shows any disposition to run. It is an immense yielder of large, handsome pods that are well filled with large beans. Pkt., 5c; 1 lb., 25c; 3 lb., $60 \mathrm{c} ; 15 \mathrm{lb}$., $\$ 2.25 ; 60 \mathrm{lb} ., \$ 8.75$.

\section{DREERS' BUSH LIMA}

Beans thicker and sweeter than large White Lima and ten days earlier; a true bush variety. Pkt., 5c; 1 lb., $30 \mathrm{c} ; 3 \mathrm{lb} ., 75 \mathrm{c} ; 15 \mathrm{lb} ., \$ 2.50$.

\section{HENDERSON'S BUSH LIMA}

The Henderson. New Bush Lima grows in a compact bush form 15 to 18 inches high and pro duces enormots crops of delicious I.ima Beans. Pkt. 5c.; 1 1b. 25c.; 3 lbs. 60c.; 15 1bs. $\$ 2.00 ; 60$ lbs. $\$ 7.75$.

\section{POLE OR CLIIMBING BEANS}

\section{OLD HOMESTEAD OR KENTUCKY WONDER}

Vines vigorous, climbing well and very productive, bearing its pods in large clusters. Blossoms white. Pods green; very long, often reaching nine or ten inches, nearly round when young and very crisp, becoming very irregular and spongy as the beans ripen. Dry beans long, oval, dun colored. Pkt., 5c; 1 lb., 25c; 3 lb., 60c; 15 lb., $\$ 2.00$; 60 lb., $\$ 7.50$.

\section{BURGER'S GREEN POD (White Kentucky Wonder)}

It is early and covers a long season of productiveness. The pods borne in clusters, average six to eight inches in length; are uniformly straight; of a rich dark green; and so meaty as to be really saddle-backed. The pods are entirely stringless, are very tender and of a sweet mild flavor. The dry beans are of a pearly whiteness. Pkt., 5c; $1 \mathrm{lb} ., 30 \mathrm{c} ; 3 \mathrm{lb} ., 75 \mathrm{c}$.

-

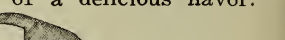




\section{POLE BEANS-Continued}

\section{EARLY GOLDEN CLUSTER WAX}

The finest of all the wax podded pole beans. It begins to bear early and continues until frost. The pods are of a beautiful golden yellow color, from 6 to 8 inches in length, stringless, and are produced in large clusters. The pods retain their tenderness long after the beans have attained a large size. Pkt., 5c; 1 lb., 30c; 3 lb., 75c; 15 lb., \$2.75.

\section{DUTCH CASE KNIFE}

The vines of this well known green podded kidney bean for green shell use are of good climbing habit, but twining rather loosely and may be used for a corn hill sort of medium season. It is used for snaps when quite young. The leaves are large and crumpled. The pods are very long, seven to eight inches, flat, irregular, medium green, becoming lighter as they mature. Seed broad, kidney shaped, flat, clear white and of excellent quality whether used green or dry.

\section{POLE LIIIA BEANS}

\section{KING OF THE GARDEN LIMA}

A strong, vigorous grower and uniformly large podded. In good soil pods will run from five to seven inches in length, frequently contain five or six very large beans. These beans are of excellent quality, easily shelled, of large size and handsome appearance. Pkt., 5c; 1 lb., 25c; 3 lb., 60c; 15 lb., $\$ 2.00 ; 60$ lb.. $\$ 7.75$.

\section{SIEBERT'S EARLY LIMA}

The earliest of all the large true Limas and when in condition to use green are larger than any other. The very best of market gardener's use. The vine is exceptionally hardy and vigorous and not only produces pods earlier, but continues in bearing longer than other sorts. The pods and green beans are as large as the largest and in quality they are excellent. A decided improvement in large Limas and cannot fail to become a favorite. Pkt., 5c; 1 lb., 25c; 3 lb., $60 \mathrm{c} ; 15 \mathrm{lb}$., $\$ 2.00 ; 60 \mathrm{lb}$., $\$ 7.75$.

\section{EXTRA EARLY JERSEY LIMA}

Of a strong growth, maturing a good crop quite early. Pods usually contain three beans each. Pkt., 5c; 1 lb., 25c; 3 lb., 60c; 15 lb., $\$ 2.00 ; 60$ lb., $\$ 7.75$.

\section{EARLY LEVIATHAN LIMA}

The earliest variety of Pole Lima; produces pods in clusters. A good variety where the season is short. Pkt., 5c; 1 lb., 25c; 3 lb., 60c; 15 lb., \$2.00; 60 lb., $\$ 7.75$.

\section{FORD'S MAMMOTH POD}

(New) The largest podded, finest flavored and most productive of all Limas. Pkt., 5c; 1 lb., 25c; 3 lb., $60 \mathrm{c} ; 15 \mathrm{lb} ., \$ 2.00 ; 60 \mathrm{lb}$., $\$ 7.75$.

\section{LAZY WIFE}

This famous variety derived its name from its immense yield, making it easy to get a supply. It cooks quickly, and is perfectly stringless if young. Nice snaps, good dry. Pkt., 5c; 1 lb., 30c; 3 lb., 75c; $15 \mathrm{lb} ., \$ 2.50$.

\section{HORTICULTURAL OR SPECKLED CRANBERRY}

One of the best varieties as a great general purpose late green shell bean for the home or market. The vines are moderately vigorous with large, light colored leaves. The pods are $4 \frac{1}{2}$ to $5 \frac{1}{2}$ inches, pale green when young, becoming as they mature yellowish green, striped or splashed with red. The beans are large, ovate, flesh colored, splashed and spotted with wine-red, and of the highest quality, either green or dry. Many like this sort better than Limas. Is also sold as Wrens Egg. Pkt., 5c; 1 lb., 25c; 3 lb., $60 \mathrm{c} ; 15 \mathrm{lb}$., $\$ 2.00$.

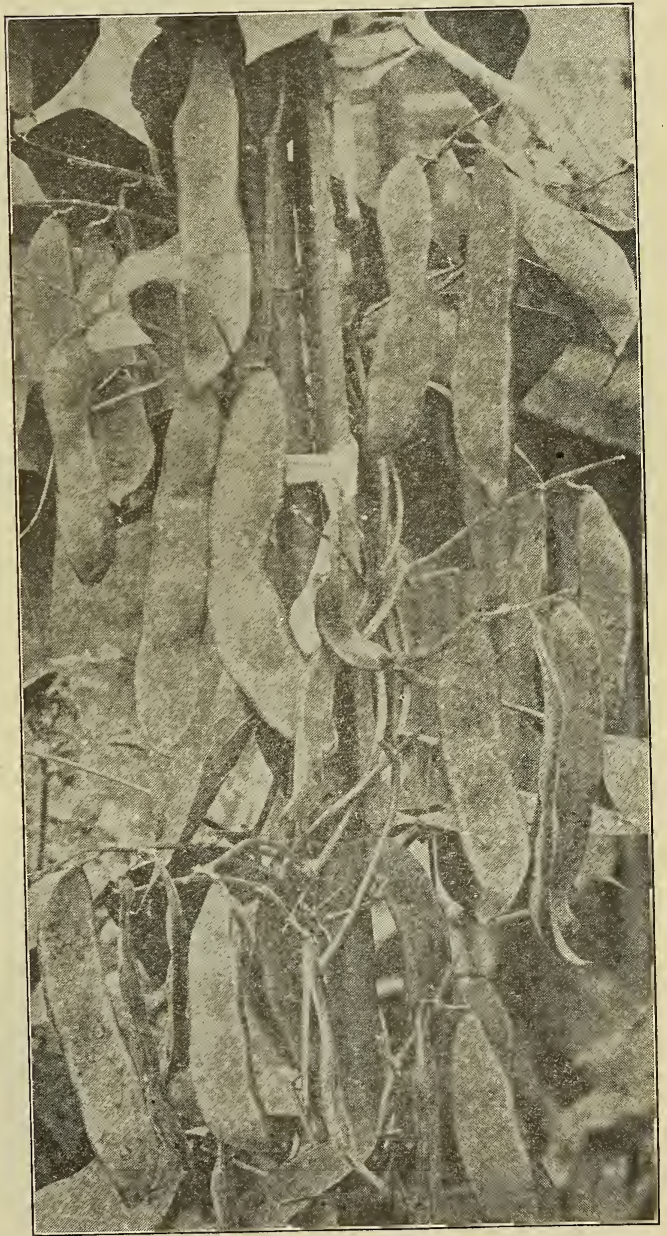

King of the Garden Pole Lima 


\section{BEETS}

One Ounce to 50 Feet of Drill. 5 or 6 Pounds to Acre

\section{CULTURE}

The soil best adapted for the beet is a rich deep loam. Sow in drills 15 inches apart, one inch reep, and thin to 6 inches. For early, sow as soon as the ground can be worked in the spring; for main and autumn, use about the 5 th of May. Sow the Mangles in drills 2 feet apart and thin to 15 inches in the row.

Our Beet Seed is all grown from carefully selected, hand-sorted roots, and none better can be obtained at any price.

\section{CROSBY'S EGYPTIAN}

This very desirable table beet does not closely resemble the original Egyptian except in its extreme earliness. The tops are small. The roots are flattened globe shaped and very smooth. The exterior color of root is bright red. The flesh is bright vermillion-red, zoned with a lighter shade, very sweet, tender and of excellent quality. This is one of the best for early planting outdoors and is much used for bunching. It is fit for use earlier than any other variety, but it is not so well suited as Extra Egyptian Blood Turnip for forcing in hotbeds or for transplanting. Pkt., 5c; oz., 10c; 1/4 lb., 30c; 1 lb., $\$ 1.00$.

\section{EDMOND'S EARLY TURNIP}

\section{(See Ilustration)}

The very flattering reports we received the past season from some of the largest gardeners who have been growing this splendid beet, and the heavy demand we have for the same, leads us to believe that the gardening public apreciates our efforts to produce a perfect beet. The Edmond is unquestionably the most perfect turnip-shaped beet on the market today. combining as it does the good qualities of the best with none of their defects. It is a very early, rapid growing sort of a very rich dark red color, with a small top, very smooth, and with no side roots, and surpassing all in flavor and tenderness. If you want the very best, as we believe you do, you will make no mistake in selecting the Edmond. Pkt., 5c; oz., 10c; $1 / 4$ lb., 30c; lb., $\$ 1.00$.

\section{ECLIPSE}

Is one of the best known of the table beets, and I have a strain of extra purity and merit, particularly noted for earliness. It is indeed high praise to say that my Eclipse beet is almost or quite as early as Egyptian, for the latter has been long accepted as the earliest of all; and Eclipse has ever been recognized as superior to Egyptian in table value. My strain has small top and is smooth, fine grained and tender, with bright red color. Many market gardeners have discarded Egyptian entirely in favor of this strain of Eclipse, and for a home garden sort it is one of the best. Pkt., 5c; oz., 10c; $1 / 4$ lb., 30c; lb., $\$ 1.00$.

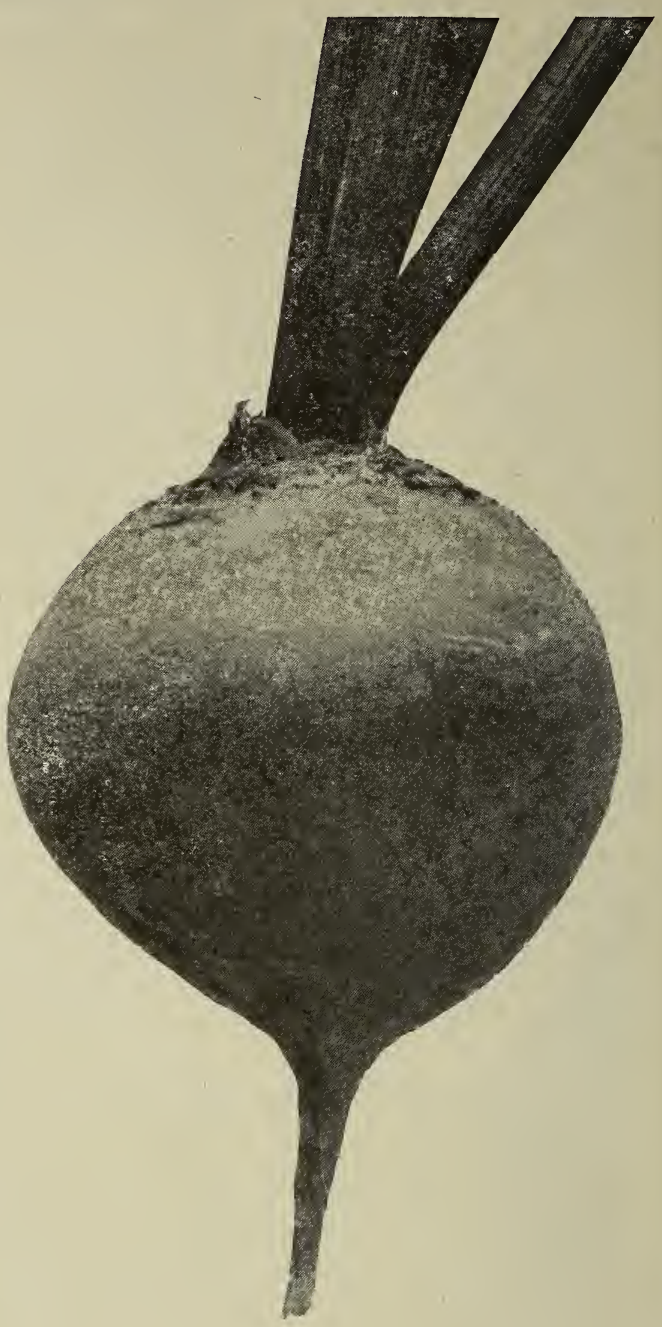

Fdmond's Early Beets

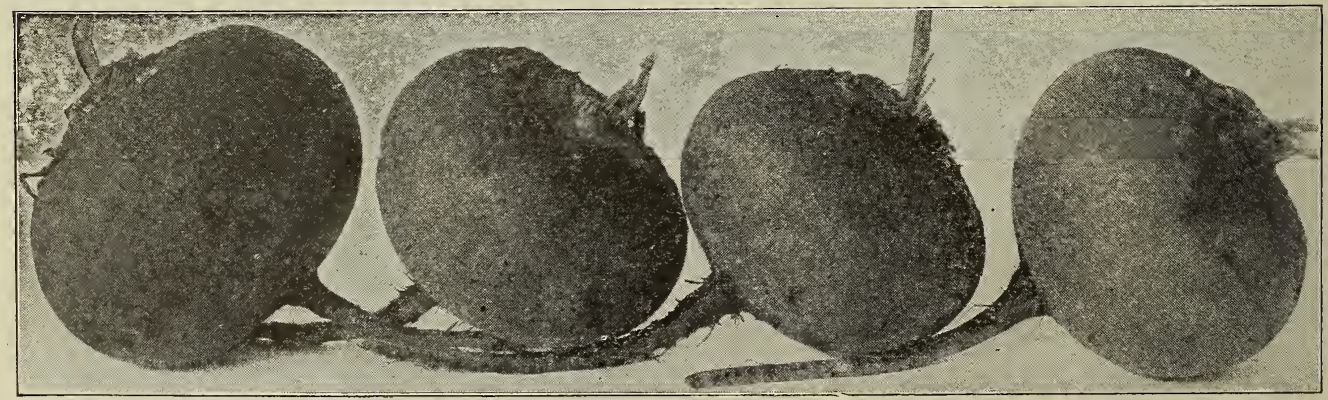




\section{DETROIT DARK RED}

\section{(See Illustration)}

A favorite among market gardeners. One of the very best red turnip-shaped varieties. Has small, upright growing tops, splendid shape. Color of skin a dark blood red, and flesh deep, bright red. Very crisp, sweet and tender. Matures early, keeps in condition for use a long time and produces a crop very uniform in shape. Pkt., 5c; oz., 10c; $1 / 4$ lb., 30c; 1 lb., \$1.00.

\section{EXTRA EARLY EGYPTIAN}

One of the earliest, of good quality and medium size; a fine forcer, small top. Pkt., 5c; oz., 10c; $1 / 4$ lb., 30c; 1 lb., $\$ 1.00$.

\section{LONG DARK BLOOD}

Excellent for winter use. Smooth skinned; flesh dark red. Pkt., 5c; oz., 10c; 1/4 lb., 25c; lb., 80c.

\section{BASTIAN'S EARLY BLOOD TURNIP}

Extra early, of quick, large growth. Flesh tender and retains its fine blood red color when cooked. Pkt., 5c; oz., 10c; 1/4 lb., 25c; lb., 80c.

\section{IMPROVED EARLY BLOOD TURNIP}

Dark red, fine flavor. Good for winter. Pkt., 5c; oz., 10c; $1 / 4$ lb., 25c; lb., 80c.

\section{SWISS CHARD OR SILVER BEET}

Grown expressly for its leaves, which make the finest greens. The middle of the leaf can be used like asparagus and the rest like spinach. If you are fond of spring greens, you should try it. Pkt., 5c; oz., 10c; $1 / 4$ lb., 30c; lb., $\$ 1.00$.

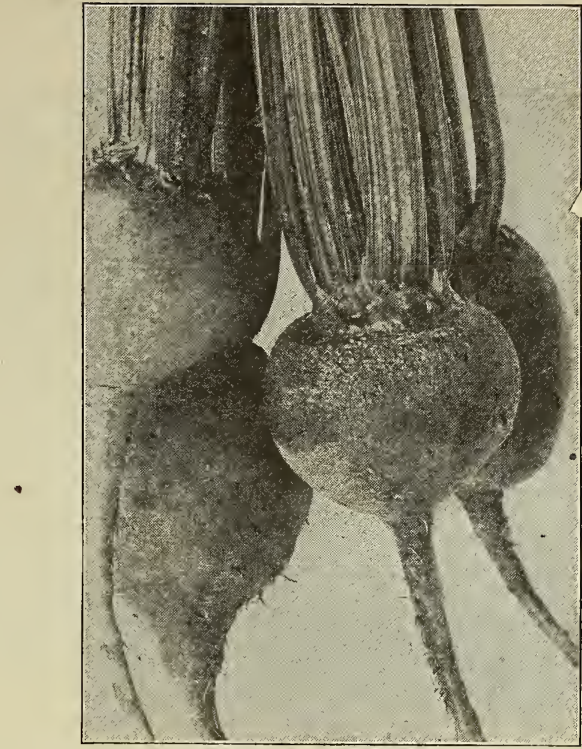

Detroit Dark Red

\section{Sugar Beets for Stock Feeding}

\section{IMPORTED YELLOW SUGAR}

Grows to a large size. Roots half long, yellow and sweet. Excellent for stock feeding. Oz., 5c; $1 / 4$ lb., 20c; lb., 50c; by express, 5 lb., or over, 35c lb.

FRENCH WHITE SUGAR RED TOP

A most desirable sort for stock feeding. $\mathrm{Oz} ., 5 \mathrm{c}$; $1 / 4$ lb., 20c; lb., 50c; by express, 5 lb., or over, 40c per $\mathbf{l b}$.

\section{KLEIN WANZLEBEN}

This is the very best variety for sugar making. It grows below the surface, and the green leaves are rather large and spreading, with waxy edges. Productive and easily grown. Probably the best sort for experiments. Oz., 5c; 1/4 lb., 20c; lb., 50c; $5 \mathrm{lb}$, or over, by express, 35c per $\mathrm{lb}$

\section{MANGEL WURZELS}

\section{GOLDEN OR YELLOW TANKARD}

In our estimation the most valuable of our Mangel beets. It contains a greater per cent of sugar than any other, and therefore more nutritious. Flesh rich, golden yellow. Roots grow well out of the ground, making it easy to harvest. Exceedingly hardy and maturing earlier than other late sorts. Oz., 5c; $1 / 4$ lb., 20c; lb., 50c; by express, 5 lb. or over, 30c per lb.

\section{GIANT FEEDING SUGAR}

A beet of highest nutritive value for feeding. The roots are of a light bronze green, somewhat egg shaped, grows partly out of the ground and because of this and their shape the crop can be harvested and stored easily and at less expense than any other root crop. Oz., 5c; $1 / 4$ lb., 20c; lb., 50c; by express, 5 lb., or over, $30 c$ per lb.

\section{MAMMOTH PRIZE LONG RED}

\section{(See Illustration)}

The roots are very large, uniformly straight and well formed; proportionately thicker, and are deeper colored than the common sort, and with small tops. We know our stock of this variety will produce the largest and finest roots which can be grown, and that it is vastly superior to many strains of the same sort offered under other names. Oz., 5c; 1/4 lb., 20c; 1 lb., 50c; by express 5 lb. or over $30 \mathrm{c}$ per $1 \mathrm{~b}$.

\section{CHAMPION YELLOW GLOBE}

A large, round, orange-colored variety of excellent quality, producing a better crop on shallow soil than the Long Red. The roots often keep better than those of the long varieties, as they can be more easily handled without injury. Oz., 5c; $1 / 4$ lb., 20c ; lb., 50c; by express, 5 lb., or over, 30c per lb.

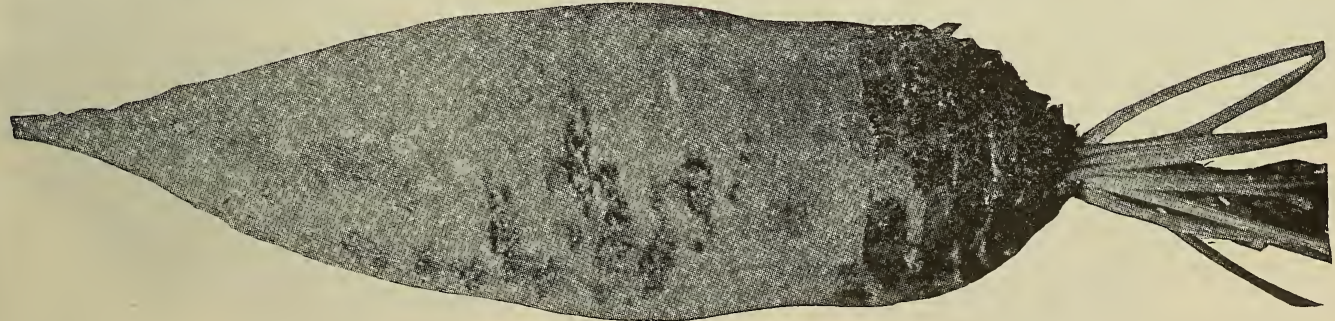




\section{BRUSSELS SPROUTS}

A plant that grows two to three feet high, and produces from the side of the stalk numerous little sprouts resembling cabbage heads, one to two inches in diameter. Pkt., 5c; oz., 15c; 2 oz., 25c.

\section{CABBAGE}

Cabbage will thrive on any good corn land, though the stronger the soil the better they will develop. New land is preferable. Plough deep and manure very liberally. The early sorts bear planting from eighteen inchs to two feet apart in the rows, with the rows from two to two and a half feet apart; the large varieties to be from two to four feet apart in the rows, with the rows from two and a half to four feet apart, but the largest varieties can be planted at the least distance wanted and do well. The crops should receive as many as three hoeings and three cultivations. Cabbage will not usually follow cabbage or turnips successfully in field culture unless three or four years have intervened between the crops. For late fall marketing plant Drumhead sorts from June 10 to 28 . One ounce to about two thousand plants.

\section{EARLY JERSEY WAKEFIELD}

\section{(See Illustration)}

We feel perfectly safe in saying that we consider we have the finest and truest stock of Jersey Wakefield in America. There is no question but that Jersey Wakefield is one of the best early cabbages in cultivation today, and it is not to be wondered at that we should take particular pains in furnishing our customers with such an extra choice strain of seed. It forms an unusually large head, almost as early as any of our other early sorts. It is always sure to mature fine, marketable heads in 100 days or less from planting. Never buy cheap seed of this variety. Pkt., 5c; oz., 20c; 1/4 lb., 75c.

\section{COPENHAGEN MARKET}

(See Illustration)

A new variety popular among market gardeners and also highly recommended for the home garden. It is very early and one of the finest, round-headed cabbages in cultivation. Each plant forms splendid heads, with tightly folded leaves. Average in weight from five to eight pounds and are about eight inches in diameter each way. The heads are very solid, have a small core and are excellent in quality. It is a short stemmed variety, making it possible to set the plants very close in the row. Pkt., 10c; oz., • $30 \mathrm{c} ; 1 / 4 \mathrm{lb}$., $\$ 1.00$.

\section{GLORY OF ENKHOUSEN}

A comparatively new Cabbage from Holland; it has met with exceptional popularity on account of its earliness, sure headiness and fine keeping quality. The heads are medium size, just right for market, globe shaped and of handsome green color. The quality is excellent, the leaves being fine ribbed and the outer leaves set close permitting close planting. Where this variety has been tried in the market growing centers, the growers have been very enthusiastic. Along with all other Holland and Danish Cabbage the seed is very scarce this year. Pkt., 5c; oz., 30c; $1 / 4 \mathrm{lb} ., 75 \mathrm{c} ; 1 \mathrm{~b} ., \$ 2.50$.

Fred W. Hobart, Granville, Ohio, writes: In regard to the corn that I bought of you, will say, it is the best corn that I ever raised. On nine acres I filled my silo which is $311 / 2 \mathrm{ft}$. high by 14 ft. in diameter, and have 5 acres to husk yet which I think will make better than 3 bu. per shock. Lots of people like it and will buy seed of me. Next year I shall plant all of this same kind.

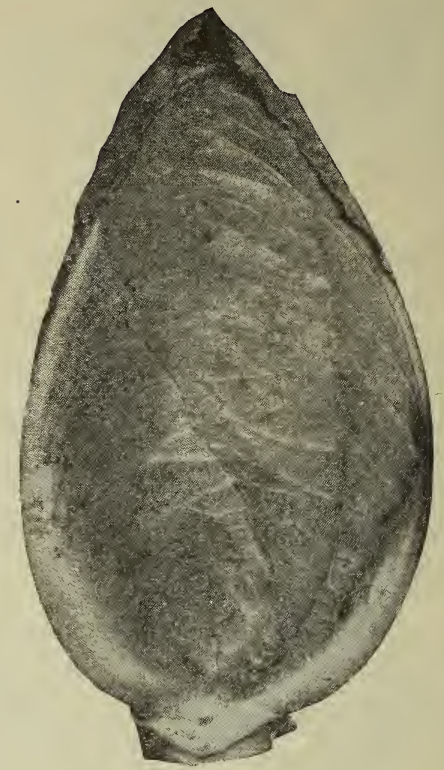

Jersey Wakefield Cabbage

\section{ALL HEAD EARLY}

Best Second Early Flat Heading. A variety that is at least a week earlier than any of the various strains of early Summer Cabbage. It is about onefourth larger than the Early Summer, and therefore much more profitable to the market gardener. The heads are remarkably solid and uniform in color, as well as in size and shape. Pkt., 5c; oz., 20c; $1 / 4$ lb., 60c; 1 lb., $\$ 2.00$.

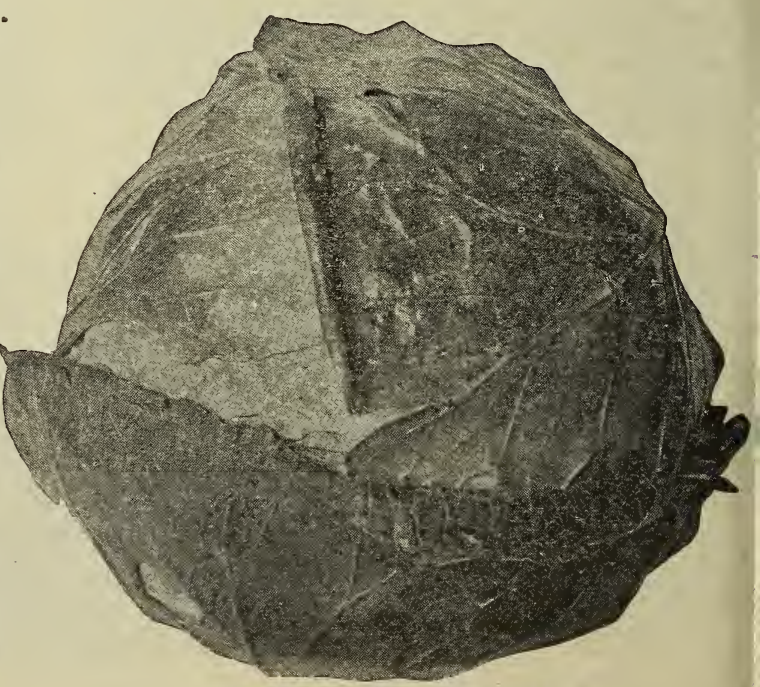

Copenhagen Market Cabbage 


\section{CABBAGE--Continued}

\section{EUREKA OR FIRST EARLY CABBAGE}

A flat headed cabbage, fully as early in maturing as the well known Early Jersey Wakefield. It is a cross of the fine strain of Early Jersey Wakefield on the well known Succession Cabbage, and is now thoroughly fixed as to type. The heads are large and very solid and the leaves tender, being entirely free from coarseness. The plants may be set in the fields as the Wakefield, and can be depended upon to head up well. Pkt., 5c; oz., 25c; $1 / 4$ lb., 75 c.

\section{DANISH BALL HEAD OR HOLLANDER}

(See Illustration)

Quite a distinct sort. Plants very hardy, rather long-stemmed, but compact; the leaves are very smooth but thick, the head is of medium size, round and very solid, being the hardest heading cabbage we know of, and of the very best quality. Matures quite late and keeps well and is considered by many the best cabbage to hold over for spring markets. Pkt., 5c; oz., 20c; 1/4 lb., 75c; lb., $\$ 2.75$.

\section{PREMIUM LATE FLAT DUTCH}

This strain is the result of much care on our part to develop and maintain the good qualities which have made this sort so popular. The plants are very hardy, comparatively slow growing but very sure heading; stems rather short. The plants are exceptionally vigorous, with very large, broad, spreading outer leaves which are moderately smooth or very slightly waved and slightly blistered. The heads are uniformly large, flat but deep, distinctly flattened on the top, solid, and of excellent quality. This is considered by many as the standard, very large late cabbage for home garden and market. Pkt., 5c; oz., 15c; 1/4 lb., 40c; 1 lb., \$1.50.

\section{EARLY WINNINGSTADT}

This well known old standard variety is always popular. In season very. close to Early Jersey Wakefield. Heads large, decidedly conical. Solid, even in summer; almost worm-proof, because so hard. A very sure header. Pkt., 5c; oz., 15c; 1/4 lb., 50c; 1 lb., $\$ 1.75$.

\section{HENDERSON'S EARLY SUMMER}

A fine, early variety. It has large flat heads that keep longer without bursting than most early sorts. Pkt., 5c; oz., 20c; $1 / 4$ lb., 60c; lb., \$2.00.

\section{SUREHEAD}

A fine winter variety. Has large, fine solid heads with many outer leaves, and is a sure header. Pkt., 5c; oz., 15c; 1/4 lb., 50c; lb., \$1.75.

\section{ALL-SEASON}

This is an early, large Drumhead variety that has become very popular. It is called "All-Season" because it is just as good to keep for winter use as it is for early market. Pkt., 5c; oz., 20c; $1 / 4 \mathrm{lb}$. 60 c; 1 lb., $\$ 2.00$.

\section{IMPROVED AMERICAN SAVOY}

The largest of the Savoys. A sure header. Very sweet and tender. Pkt., 5c; oz., 20c; $1 / 4$ lb., 60c; 1 lb., \$1.75.

\section{LOUISVILLE DRUMHEAD}

Dark Bluish-green color. Popular in the Southwest and sweet and tender. Pkt., 5c; oz., 20c; 1/4 lb., 60c; 1 lb., Southern States... Oz., 15c; 1/4 lb., 60c; 1 lb., \$2.00.

\section{PREMIUM LATE DRUMHEAD}

This is a standard late sort. Large and solid. Always a sure header and noted for its excellent quality. Pkt., 5c; oz., 10c; 1/4 lb., 50c; 1 lb., \$.1.75.

\section{LUPTON}

One of the best late Drumhead sorts. Pkt., 5c; oz., 20c; $1 / 4$ lb., 75 c.

\section{CHARLESTON OR LARGE WAKEFIELD}

An excellent second early variety with large pointed heads. Pkt., 5c; oz., 20c; $1 / 4$ lb., 75 c.

\section{MAMMOTH ROCK BED}

Used for pickling. Pkt., 5c; oz., 20c; 1/4 lb., 50c; 1 lb., $\$ 1.75$.

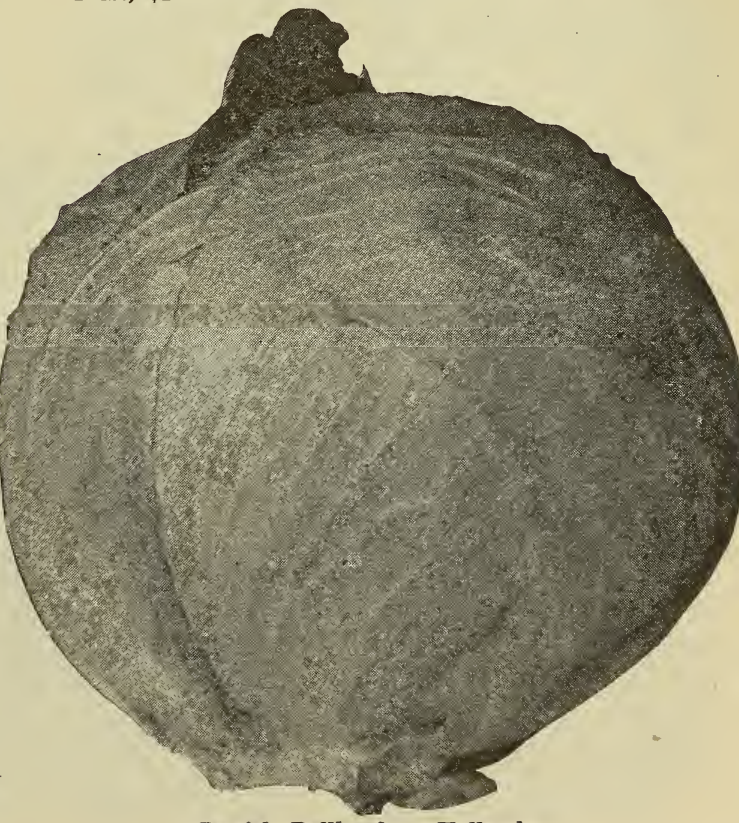




\section{CARROTS}

\section{Culture}

Carrots thrive best in a sandy loam free from stones. The ground should be well manured with fine well-rotted composted manure, eight cords to the acre, and be thoroughly worked quite deep, by two plowings made at the right angles with each other. Also cultivate and drag, if there are any lumps, and then rake level, burying all remaining lumps and stones. Plant in rows fourteen inches apart, and thin plants three to four inches in the rows. Plant from the middle of April to the middle of May to insure crop. As the dry spells which sometimes prevail in June are apt either to prevent the germination of the seed or to burn the plants as soon as they appear above ground, it is therefore advisable to increase the quantity of seed which, under the circumstances, will give the crop a better chance. Keep very clean of weeds. One ounce will sow 100 feet of drill. Three pounds will sow an acre.

\section{EARLY SCARLET HORN}

May be planted very early in spring. and is an excellent summer variety. Tops small and roots grow about 3 inches long; reddishorange and good flavor. May be grown either in frames or in the open ground. Pkt. 5c; oz., 20c; $1 / 4$ lb., 50c; 1 lb., $\$ 1.50$.

\section{DANVERS' HALF-LONG ORANGE}

Is in form about midway between the Long Orange and Ox-Heart, growing generally with a stump root. It is of a rich, dark orange color, grows to a large size, is smooth and the flesh very close texture, with little core. It is a first class carrot for all soils, and it is claimed that under good cultivation it will yield the greatest weight per acre with smallest length of root of any grown. Pkt., 5c; oz., $10 \mathrm{c} ; 1 / 4$ lb., 30c; 1 lb., $\$ 1.00$.

\section{GUERANDE OR OX-HEART}

This carrot is a splendid sort. In length it comes between Early Scarlet Horn and Danvers' Half Long. It runs fully three to four inches in diameter, and specimens have been raised measuring over seven inches in diameter. In quality it is extra good, and will prove satisfactory for home use and profitable for market. Ox-Heart can easily be pulled, which makes the harvesting of the variety quite inexpensive. If you want an early, handsome, ready selling carrot, this sort will suit you. It will yield as heavy a crop as the Danvers, with this advantage, that it can be grown thicker and can be raised on stonier land. Pkt., 5c; oz., 10c; 1/4 lb., 30c; 1 lb., $\$ 1.00$.

\section{IMPORTED LONG ORANGE}

One of the most desirable for either garden or field culture. It grows to a large size, fair specimens averaging twelve inches in length, and three inches in diameter, at the top. All who have cattle should raise a surplus of this carrot for feeding milk cows during winter. It increases the flow of milk and imparts to the butter a delicious flavor and a rich golden color. Pkt., 5c; oz., 10c; 1/4 lb., 30c; lb., $\$ 1.00$.

\section{WHITE BELGIAN}

Large, good for stock feeding. Pkt., 5c; oz., 10c; $1 / 4$ lb., 25c; lb., 85c.

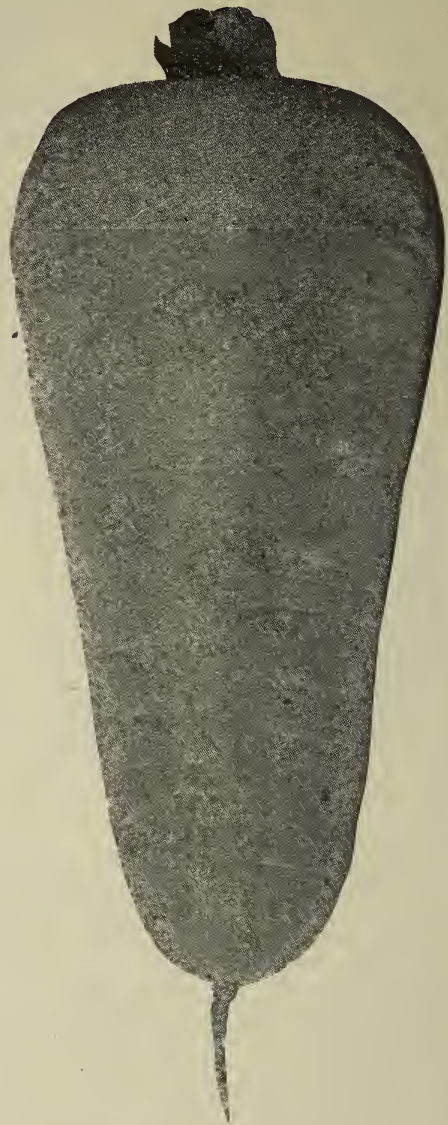

\section{CHANTENAY}

(See Illustration)

A handsome cylindrical carrot of good size and stump rooted. It is a rich dark orange color, grows to a large size, is smooth and the flesh very close in texture, with little core. It is a first class carrot for all soils, and it is claimed that under good cultivation it will yield the greatest weight per acre with the smallest length of root of any now grown. Pkt., 5c; oz., 10c; 1/4 lb., 30c; lb., \$1.00.

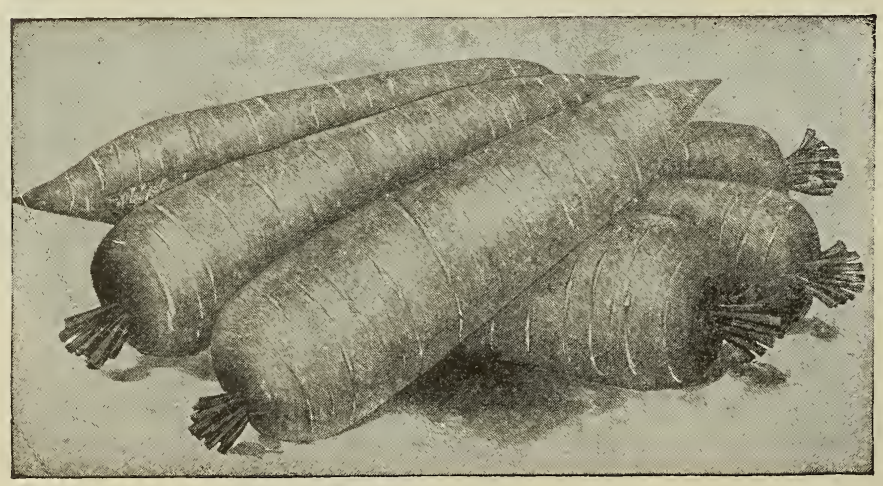

Danvers' Half Long

\section{- Testimonials}

Frank W. Atwood, Conneautville, Pa., writes: The seed corn was fine. My neighbors said I had the best corn in the vicinity. We were very much pleased.

Bertic Blancit, Charleston, W. Va., writes: I thought I would write and thank you for the seeds I got of you last spring. They were true to name and just what you said they were. If I am living I will get all my seeds from you next year.

W. S. Fleming. Morgantown, W. Va., writes: Through sickness I did not get to work my corn the way I wanted to but I have some fine corn. It can't be beat in this community. Many of the ears weigh over $1 \mathrm{lb}$. apiece. 


\section{CAULIFLOWER}

\section{CULTURE}

For earliest Cauliflower, raise plants by sowing in hotbed or greenhouse during January or February, and transplant to flats or cold frames, 2 or 3 inches apart each way. Set in open ground as soon in spring as the land can be put in good order. Soil to be a warm, very rich, fibrous loam, well supplied with humus and moisture. Copious water applications during dry weather, especially when the plants are heading, and light dressings of nitrate of soda and potash are of much help. Set plants 2 to $21 / 2$ feet apart each way. When heads have formed and are hard, they should be blanched by drawing the leaves together and tying with raffia, or strips of soft cloth. For late Cauliflower, to mature during the pickling season (August 15th to October 10th), start plants in the open ground like late cabbages, and handle them like that crop.

\section{EARLY SNOWBALL}

\section{(See Illustration}

Whether introduced for private use or grown for market, Early Snowball is superior to all others. First, because it is the earliest of all Cauliflowers, as has been conclusively shown season after season since we first made its merits known. Second, because under the condition of an ordinary favorable season, nearly every plant will form a perfect snowball head, averaging nine inches in diameter. Third, for the reason that its close growing, compact habit enables one-third more to be planted on the same space of ground than can be done with any other variety. For forcing under glass during winter and spring the Early Snowball variety is perculiarly well adapted from its dwarf growth and short outer leaves, and for this purpose no other Cauliflower is now so largely grown. Pkt., 15c.; 1/4 oz., 50c.; oz., \$1.75; 1/4 lb., \$6.50; lb., \$22.00.

\section{DRY-WEATHER CAULIFLOWER}

This superior strain of Cauliflower was originated in Copenhagen, Denmark, and is especially adapted for sections subject to long, dry seasons, as it will grow well and produce the finest heads in spite of the lack of moisture which is required by other sorts. The heads grow to a large size, are very solid, pure white and of delicious flavor. It will prove valuable for growing in the Southern States, where the climate is hot and long seasons of dry weather are experienced. Pkt., 15c.; 1/4 oz., 80c.

\section{VEITCH'S AUTUMN GIANT}

One of the finest late varieties, of robust habit heads large, compact and thoroughly protected by the leaves. Pkt., 10c.; oz., 50c.; 1/4 lb., \$1.75.

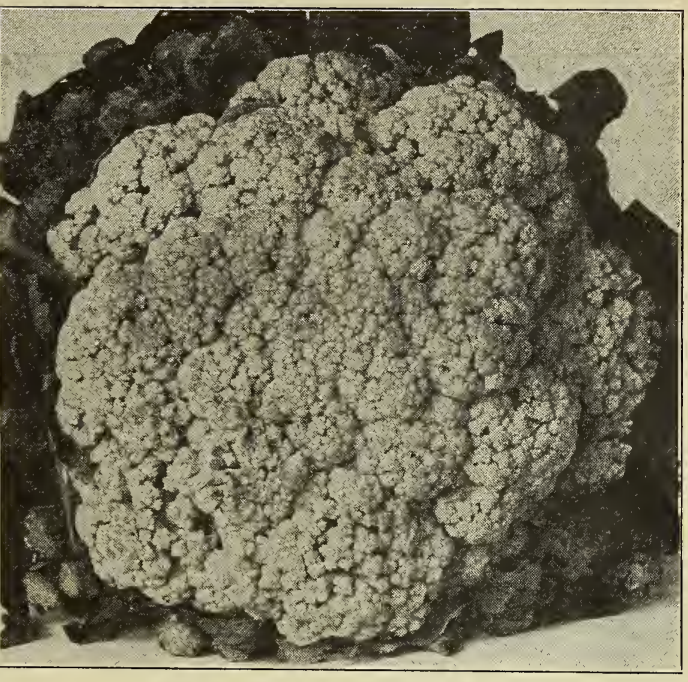

Early Snowball Cauliflower

\section{DAVIS’ EARLIEST DWARF ERFURT}

Most desirable for forcing or for planting in the open ground. This is a thoroughbred strain of this popular variety. It is a trifle earlier than the Snowball and Dwarfer, otherwise quite smaller. This seed will produce Cauliflower the equal of anything on the market. Good strains of this seed have a fifty to sixty year pedigree. They are so highly bred that it is very seldom the plants average a good seed crop, hence the best seed is always scarce and dear. Our seed is from a famous grower whose strain is unexcelled. Pkt., 10c.; 1/4 oz., 60c.; oz. $\$ 2.00$.

\section{Testimonials}

C. J. Spangler, Weedville, Pa., writes : The White Cap Yellow Dent Corn I bought of you was fine and I had good luck. As for the growing of it, every hill came up.

John A. Irion, Gallipolis, Ohio, writes : The seeds sent us gave entire satisfaction and made good crops. You will receive orders from us again next spring.

Cora Hall, New Berlin, N. Y., writes : I like your seeds very much. Please send me a catalog every year.

Gregor Betz, Wilkinsburg, Pa., writes : Wish to say that the seeds I purchased from you this year have all done well, especially the Davis' Golden Mammoth Corn. I planted about two acres and expect to take off over 100 bushels of corn, all big ears and all well filled out. I planted all by hand, and can truthfully say that I do not know of one grain that did not come up. I have looked over the whole country hereabouts and can find no corn the equal of mine.

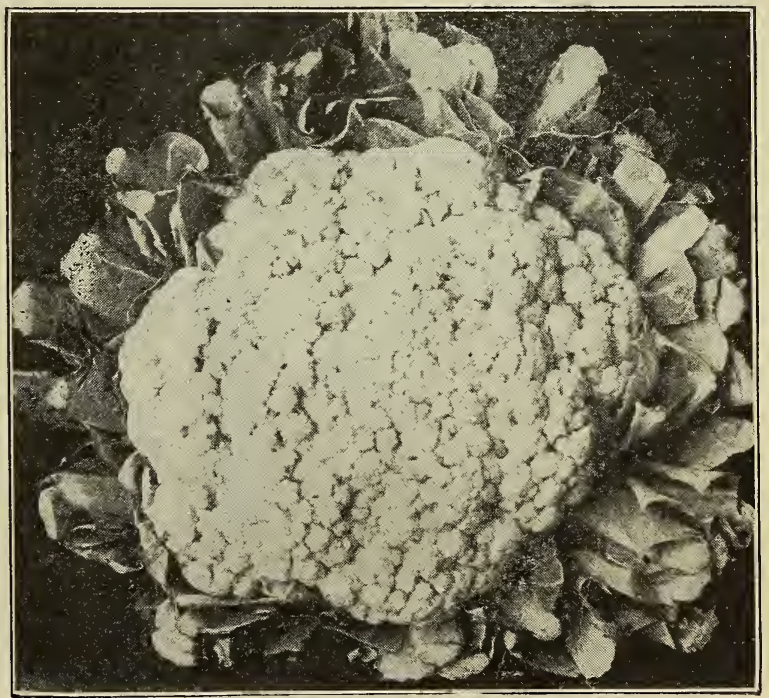

Dry Weather Cauliflower. 


\section{CELERY}

\section{CULTURE}

Celery Seed is slow to germinate, and ample time must be given. Sow thinly, cover lightly. Keep constantly moist. Count on about 7,500 plants per ounce of seed, or $1 / 4 \mathrm{lb}$. per acre. When seedling plants are 3 inches high they should be clipped at the top, to favor stocky growth, or else transplanted. Celery is moștly grown under flat culture, without trenches, in rows 3 to 5 feet apart. For home use Celery is often grown in double rows, to inches apart, without trenching, and banked for winter storage just where it is grown, without lifting.

\section{CHICAGO GIANT SELF-BLANCHFNG}

A fine new white celery, introduced four years ago by a Chicago Seed House. The points in its favor over older varieties are earliness, size and solidity; eariier and larger than White Plüme, as large as Golden Self-Blanching and of a much better quality than any other white. For early use, this celery may be sown as early as February without causing it to run to seed, and with such sowing it can be marketed as early as July 1.

In side by side tests with White Plume, Chicago Giant has outclassed it in earliness, flavor, size and solidity of heart; in height it stands equally six inches above White Plume. Its foliage is green and white and the stalks are tender, brittle, very sweet, and of a nutty flavor. Pkt., 10c.; oz., 40c.; $1 / 4$ lb., $\$ 1.00$.

\section{WINTER QUEEN}

A fine winter variety; rich golden-yellow heart. Pkt., 5c.; oz., 20c; $1 / 4$ lb., 50 c.

\section{COLUMBIA}

An early variety of good size and shape. Stalks are thick, almost round, and have a rich yellow color. Matures early, is very crisp, and has an excellent flavor. Looks like the popular Golden SelfBlanching after being stalked. Pkt., 10c.; oz., 60c.; 1/4 lb., \$1.50.

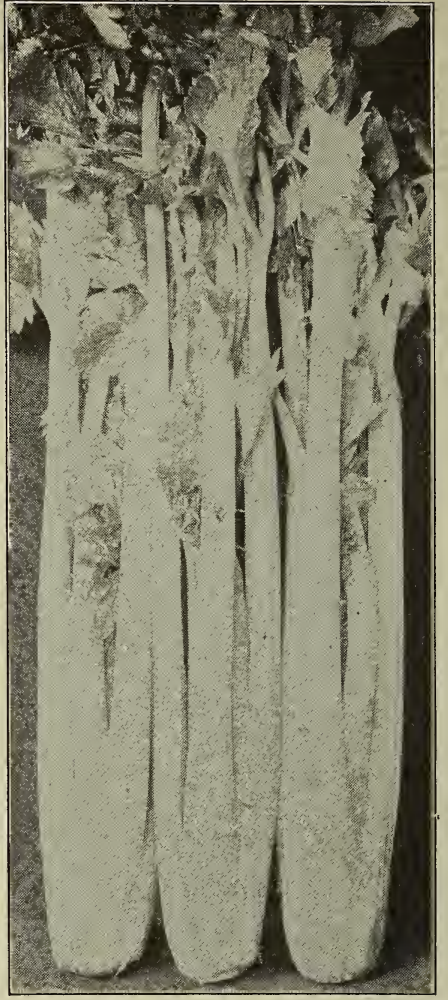

Golden Self-Blanching

\section{GOLDEN SELF-BLANCHING}

(See Illustration)

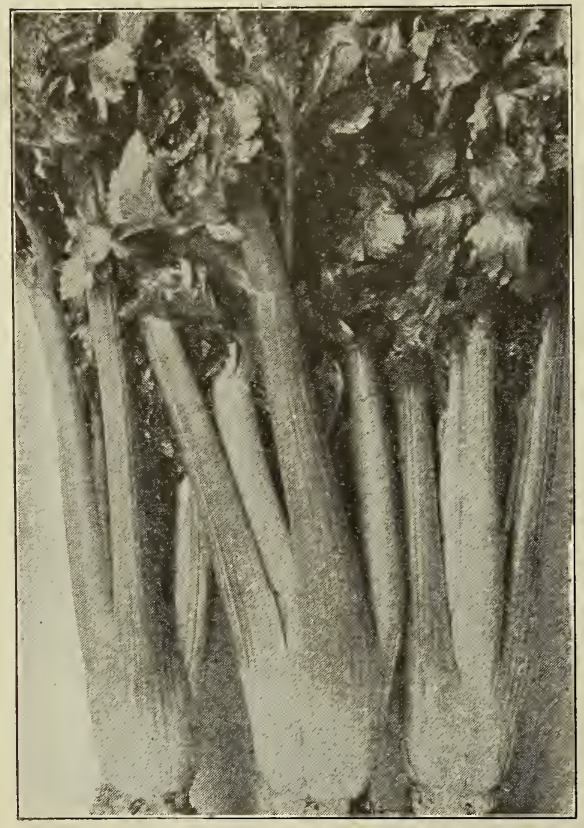

Giant Pascal Celery

This variety, first introduced in America in 1884, is decidedly better in quality than the White Plume. It is ready for use nearly as early, blanching as easily, and is larger in size, as well as finer in quality. It is of dwarf, compact habit, with thick, solid, heavily ribbed stalks, which blanch easily to a clear, waxy yellow. When grown in rich, moist soil, the stalks are numerous, each plant being fully as thick through as the largest/ of the tall, late sorts, and with a very large, solid heart of beautiful golden yellow stalks and leaves. Pkt., '10c.; oz., $\$ 1.25$; $1 / 4$ lb., $\$ 4.50$; lb., $\$ 17.50$.

\section{WHITE PLUME}

No other variety could have gained so much favor more rapidly than this. Planters claim it will branch more rapidly than others. Its eating qualities are of the best, being crisp, solid and of a pleasing nutty flavor, while its white, featherlike foliage places it ahead of all others as a table ornainent. Pkt., 5c.; oz., 20c.; 1/4 lb., 75c.; lb., \$2.50.

\section{GOLDEN HEART}

A standard sort with gardeners. Solid and an excellent keeper, of fine nutty flavor. Pkt., 5c.; oz., 20c.; 1/4 lb., 50c.; lb., $\$ 1.50$.

\section{GIANT PASCAL}

\section{(See Illustration)}

A wonderfully fine variety, with extremely large, thick stalks, and entirely stringless. Brittle and snap like glass. Is almosi self-blanching. Pkt., 5c.; oz., 20c.; 1/4 lb., 60c.; lb., $\$ 2.00$. 


\section{SWEET CORN}

We do not pay the parcel post on pound lots or over of corn

CULTURE

Thrives best on a rich, warm soil, sod land, or where clover has been turned under. Plant after danger from frost is passed, in hills $3 \times 3$ feet apart, or for larger varieties $3 \times 4$ feet apart; drop 6 to 8 grains per hill and thin out to not over 3 stalks to the hill. Keep ground well cultivated. Plant at the rate of one quart for 200 hills, 6 to 8 quarts per acre.

\section{GOLDEN BANTAM SWEET CORN}

\section{(See Illustration)}

The fact that the grains of this variety are yellow is an indication of hardness and its value for early planting and early maturing. It is a rapid grower, and produces ears measuring about five inches, but the smallness of the ears is fully made up in the delicious sweet flavor and tender quality of the corn when cooked. It is a fine variety for the home garden. Pkt., 5c.; 1 lb., 20c.; 3 lb., 50c.; 10 lb., $\$ 1.25 ; 50$ lb., $\$ 5.00$.

\section{BANTAM EVERGREEN}

This new Corn is a most desirable second-early or mid-season variety, growing vigorously from six to seven feet in height, and producing an average of two good ears to a stalk. The ears are ready for use five to seven days later than those of the Golden Bantam, and are from seven to nine inches in length, with from twelve to sixteen rows of deep, rather slender grains of rich yellow color. It has a delicious flavor, surpassing most other mid-season varieties in quality, and does not have that mealy taste so characteristic of the yellow varieties. The grains are exceptionally large and full of milk, and remain soft and tender longer than any other second-early variety. We have found it very sweet after we had thought it past the eating stage. Pkt., 5c.; 1 lb., 20c.; 3 lb., 50c.; 10 lb., \$1.75.

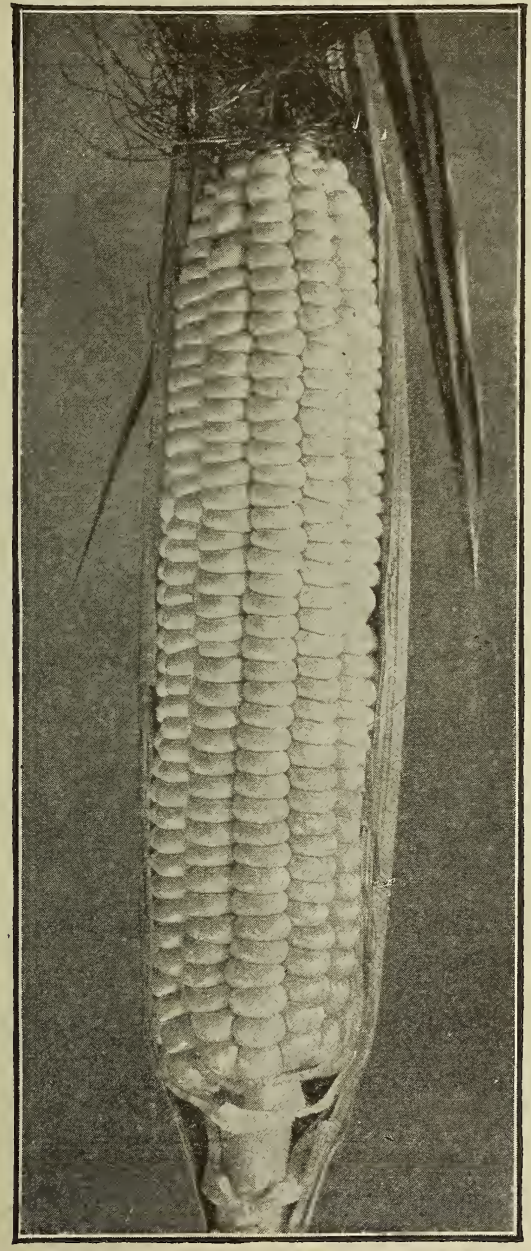

\section{TESTIMONIAL}

E. H. Decker, Delaware, Ohio, writes: The Golden Mammoth procured of you last spring was of strong germination, although dry weather caused a great deal of missing stalks, yet the acre yielded $1181 / 2$ bushels of shelled corn, and shelled $80 \mathrm{lbs}$. to 100 lbs. of ears. Think if season would have been favorable, would have raised at least 15 or 20 bushels more. Golden Mammoth is surely a great yielder on black ground. Our boy won the trip to Washington on it, and would have won the County prize had there been one offered.

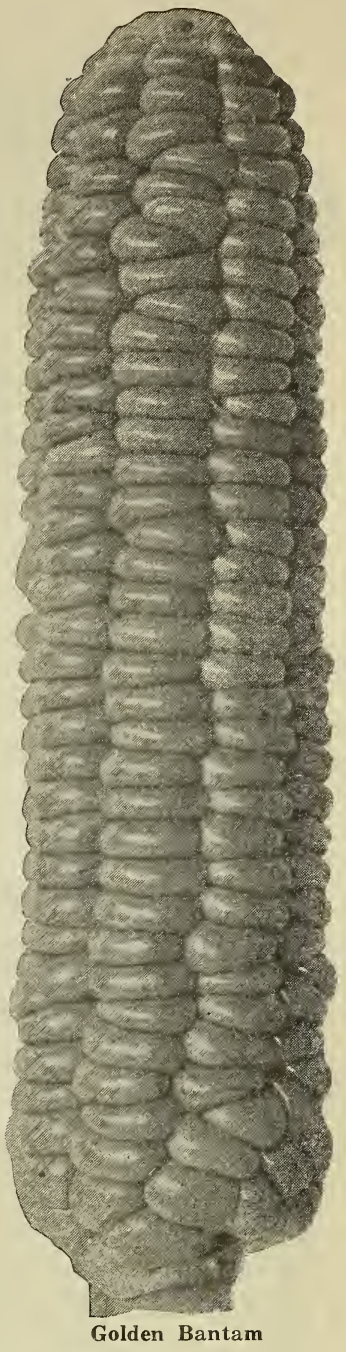

Golden Bantam

\section{HOWLING MOB}

This new sweet corn was originated by C. D. Keller, of Toledo, who gave it the peculiar name because of the demand he had for this corn when he brought it to market. Mr. Keller's aim was to have a very early corn with a large ear and the sweet flavor that is found in the later varieties which is usually lacking in an early variety. It grows from four to five feet high and usually has two good ears to the stock. The ears grow from eight to ten inches long and covered with a very tough husk which extends well over the end of the ear and protects the grain from the ravage of worms. In season of maturing it is about a week later than the Cory. The ears have twelve or fourteen rows of pearly white grains of good depth, which are very sweet and tender. We consider it one of the very best second-early corns for either home use or market. Pkt., 5c.; 1 lb., 15c.; 3 lb., 40c.; 10 lb., $\$ 1.00 ; 50$ lb., $\$ 4.50$.

\section{GOLDEN CREAM}

This new sweet corn is of California origin and the result of crossing the Golden Bantam and the Country Gentlemen. It is entirely distinct, being of dwarf habit in growth, having a ear about the length of the Golden Bantam, and differs from the Country Gentlemen in time of maturity, being very early.

The combination of good qualities of the varieties which produced the Golden Cream insuring to a reasonable degree of certainty that the product would be of more than ordinary quality, its earliness and productiveness, should induce a trial of it by all who cultivate sweet corn. Pkt., 5c.; 1 lb., 20c.; 


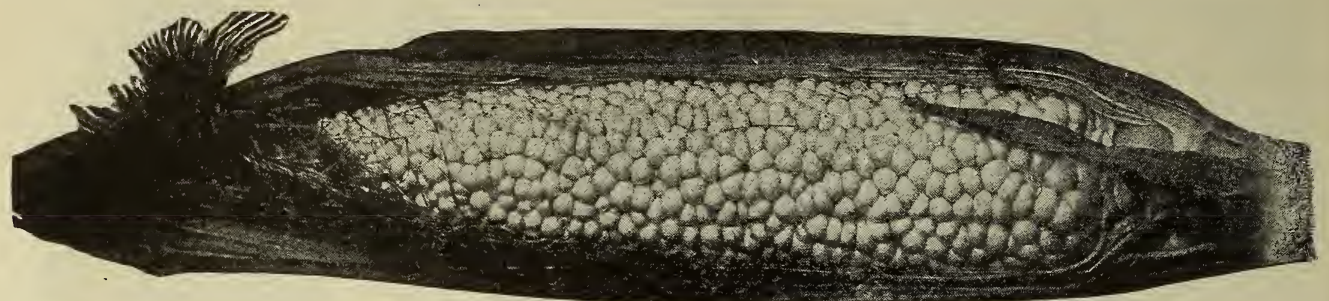

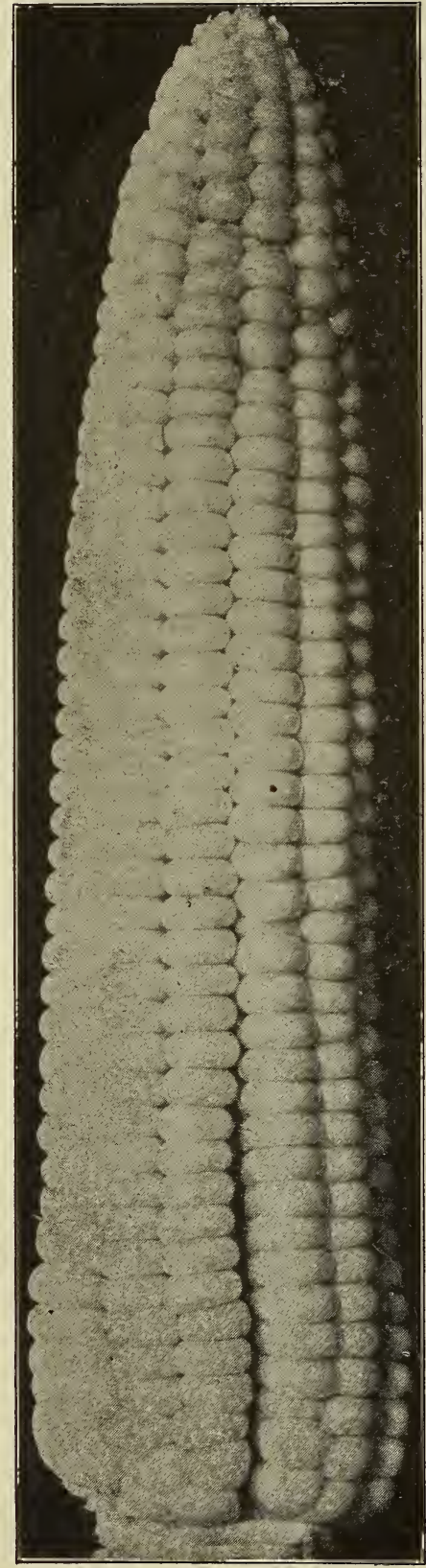

Kendel's Early Giant

Country Gentleman

\section{SWEET CORN-Continued}

\section{KENDEL'S EARLY GIANT}

(See Illustration)

The largest of all sweet corn, as early as Cory, but not as early as Premo. Where size of ear is of more importance than extreme earliness, this splendid corn still maintains its lead, as it is beyond dispute the earliest large-eared corn ever introduced. It matures with us in from sixty to sixty-five days, producing large, well-filled ears 10 to 12 inches in length. The kernels are pure white, very sweet and deep, and are very productive. Pkt., 5c.; 1 lb., 15c.; 3 lb., 40c.; 10 lb., \$1.00; 50 lb., \$3.75.

\section{COLUMBUS MARKET}

A splendid market sort, ready to use very soon after Early Minnesota, but the ears are much larger, being fully as large as Stowell's Evergreen. The tips of the ears are often covered entirely over with kernels. The ears carry an average of 16 rows of fine, large, deep, white, sweet grains, which are second to none in tenderness and flavor. It is a very prolific variety, and so persistently evergreen as to render very difficult to cure for seed. Stalks strong and of medium height. Pkt., 5c.; 1 lb., 15c.; 3 lb., 40c.; 10 lb., $\$ 1.00 ; 50$ lb., $\$ 4.00$.

\section{PREMO}

The Earliest Sugar Corn, being fully a week earlier than the Extra Early Adams. Testimonials from growers in all parts of America convince us that we now have the earliest, finest flavored and most productive sweet corn that has ever been produced. It is remarkable for its fine appearance so early in the season, and while the ears are not quite so large as the late sorts, they are always well-filled and the kernel is of the best quality. From actual tests in a fair season, good ears for boiling can be grown in fifty days from planting of good seed. This is a record which is unequaled by any other corn. We have never seen anything that can equal Premo, either for private gardens or for the largest gardeners who make a specialty of supplying the early markets. The seed of this corn will stand earlier planting than most any other, which is a point of great importance to market gardeners. The way to find this out is to try it. We certainly recommend it very highly, for we feel it will please everyone of our customers who try it. Pkt., 5c.; 1 lb., 15c.; 3 lb., 40c.; 10 lb., $\$ 1.00$.

\section{EXTRA EARLY CORY}

One of the earliest varieties. Large ears, considering size of stalks. Small red cob, well filled up with handsome and very sweet kernels. Pkt., 5c.; 1 lb,, 15c.; 3 lb., 40c.; 10 lb., $\$ 1.00$.

\section{MAMMOTH WHITE CORY}

This new strain is as early as the ordinary Extra Early Cory, with ears of larger size and kernels more compact. Cob and kernels are pure white. Pkt., 5c.; 1 lb., 15c.; 3 lb., 40c.; 10 lb., $\$ 1.00$. CROSBY'S EARLY

A most excellent early variety of fine quality. Ears $51 / 2$ to $61 / 2$ inches long, fourteen rowed or more with short, nearly square grains, which are very white, sweet and tender. This is the sort so largely grown in Maine for canning, and it is the use of this variety rather than any peculiarity of the soil that has given Maine sweet corn its reputation for quality. Pkt., 5c; 1 lb., 15c; 3 lb., 40c; 10 lb., $\$ 1.00$.

\section{COUNTRY GENTLEMAN}

A sort that produces ears of full size, retaining all the delicious sweetness and high quality of the Ne Plus Ultra. The cob is very small, densely covered with irregular rows of very long, slender white grains. The crop can be depended on to give 3 to 5 ears to the stalk. Pkt., 5c.; 1 lb., 20c.; 3 lb., 50c.; 10 lb., \$1.25. 


\section{SWEET CORN-Continued}

\section{EXTRA EARLY ADAMS}

While not a sweet corn, this is a tender white corn for table use. Ears about eight inches long, twelve or fourteen rowed, kernels white, rounded, somewhat deeper than broad. Pkt., 5c.; 1 lb., 15c.; 3 lb., 40c.; 10 lb., 80c.

\section{BLACK MEXICAN}

Black grains, very sweet and rich in flavor. Pkt., 5c.; 1 lb., 15c.; 3 lb., 40c.; 10 lb., $\$ 1.00$.

\section{EARLY MINNESOTA}

A standard early sort for family or market gardeners' use. Pkt., 5c.; 1 lb., 15c.; 3 lb., 40c.; 10 lb., \$1.00.

\section{EARLY EVERGREEN}

An excellent kind. Ten days earlier than Stowell's Evergreen and its equal in quality. Pkt., 5c.; 1 lb., 15c.; 3 lb., 40c.; 10 lb., \$1.00.

\section{STOWELL'S EVERGREEN}

A favorite with canners and market gardeners for late use, and especially for the kitchen garden. Ears large, kernels very deep, tender and of most delicious flavor. Very productive. Pkt., 5c.; 1 lb., 15c.; 3 lb., 40c.; 10 lb., \$1.00; 50 lb., $\$ 3.25$.

\section{NEW WHITE EVERGREEN}

This is a high-bred, pure white type of the ever-popular Stowell's Evergreen. From one pure white-grained ear, accidentally discovered some years ago, it has been developed by careful selection. Stalks very vigorous, 6 to 7 feet high. The ears are very uniform in size, being large and well filled to the tip with long, slender kernels. Market gardeners and all lovers of Sugar Corn have been wishing for a white sweet corn as good as Stowell's Evergreen. They can now have it-sweet and tender. When in the green state, both kernels and cobs are white as snow. Pkt., 5c.; 1 lb., 15c.; 3 lb., 40c.; 10 lb., $\$ 1.00$.

\section{MAMMOTH SUGAR}

Although this is one of the largest sweet corns grown, it is of excellent quality, yielding a big supply of fodder. Pkt., 5c.; 1 lb., 15c.; 3 lb., 40c.; 10 lb., \$1.00; 50 lb., \$3.50.

\section{POP CORN}

\section{GOLDEN QUEEN}

Ears of a large size and a beautiful golden color. It pops perfectly white. A single kernel will expand to the diameter of one inch.

\section{MAPLEDALE PROLIFIC}

The most productive popcorn, averaging 6 to 8 ears to the stalk.

\section{WHITE RICE}

A splendid variety for popping purposes. Grain shapely, pointed. Price of above: Large packet, 5c.; lb., 20c.; postpaid; by express or freight, 10c. lb.; 3 lb., $25 \mathrm{c}$.; $25 \mathrm{lb}$. and over, $6 \mathrm{c}$ per $\mathrm{lb}$.

\section{Testimonials}

Ernest Motter, Waynesburg, Ohio, writes: I am well pleased with the seeds that I received from you; they proved better than any seed that $I$ ever received from any other firm. I expect to buy my seed from you next year.

Mrs. O. Emptage, Upper Sandusky, Ohio, writes: The Pride of the North seed corn I purchased of you is coming up so satisfactory I would like prices on Millet and Hungarian Seed.

\section{EARLY ADAMS OR BURLINGTON}

Similar to Extra Early Adams, only a week later. Pkt., 5c.; 1 lb., 15c.; 3 lb., 40c.; 10 lb., 80c.

\section{ZIG ZAG EVERGREEN}

About ten days earlier than Stowell's. Pkt., 5c.; 1 lb., 15c.; 3 lb., 40c.; 10 lb., $\$ 1.00$.

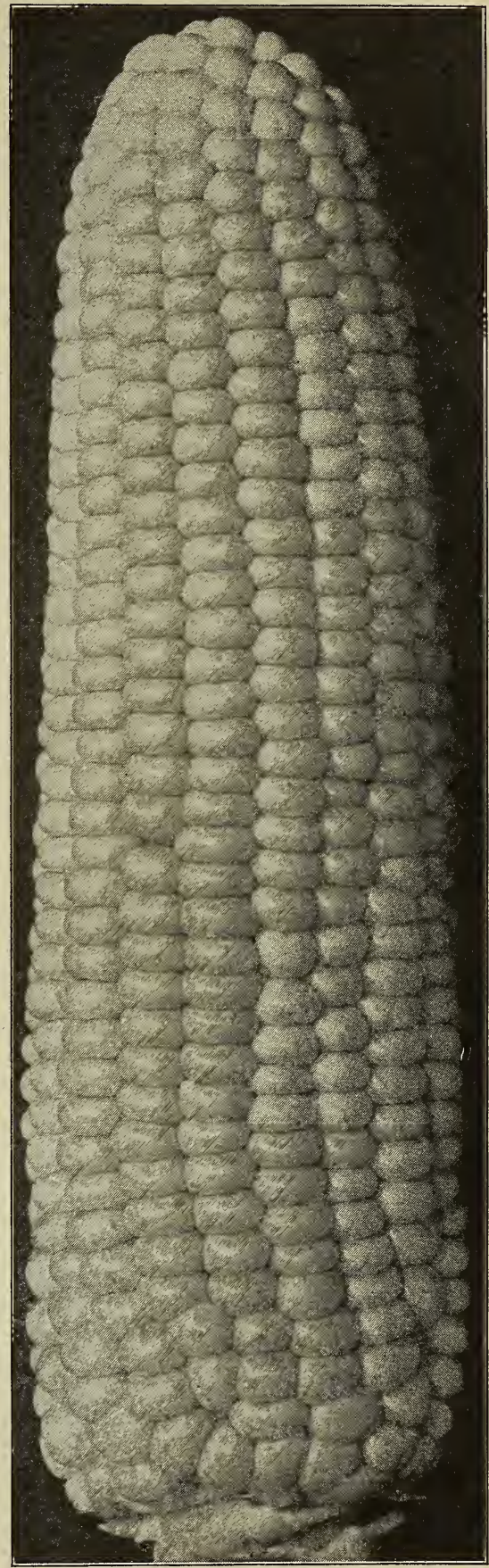

New White Evergreen. 


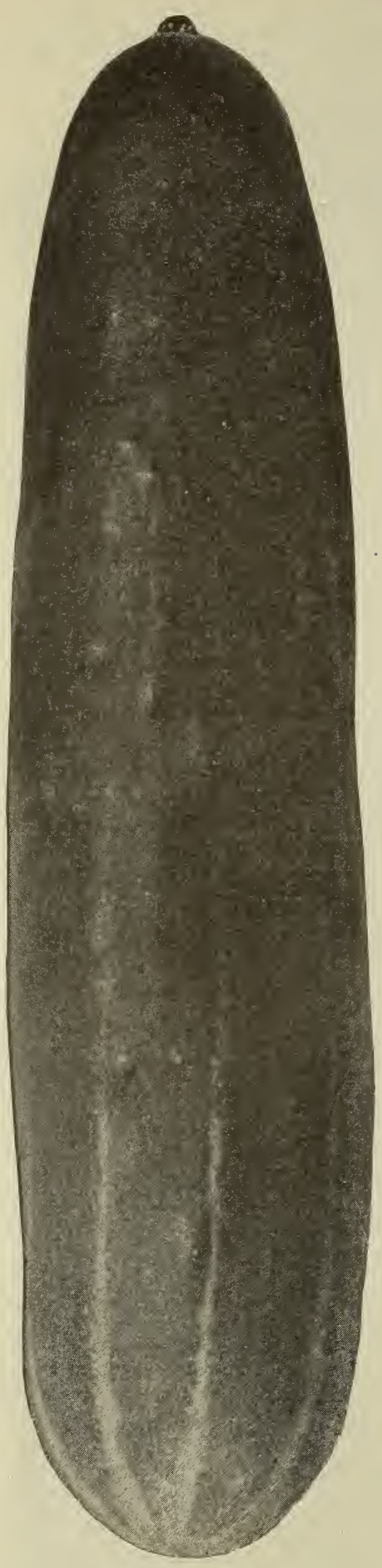

Davis Perfect Cucumber

\section{CUCUMBERS}

\section{One ounce will plant 50 hills.}

\section{Two ounces will plant one acre.}

Cucumbers succeed best in a loamy soil. For first early sow in hotbed in berry boxes or in small flower pots, six weeks before they can be set out in open ground. When danger of frost is over, transplant in hill four feet apart each way. For general crop, plant in open ground in May, about twelve seeds in a hill. When danger of bugs is past, thin to four strong plants in a hill. For pickling, plant in June. Sprinkle the vines with plaster or air-slack lime to protect them from bugs, or use slug shot to kill the bugs.

\section{DAVIS PERFECT}

\section{(See Illustration}

A new variety originated by Mr. Eugene Davis, of Michigan, which will soon take the place of the best strains of the White Spine Cucumbers. Mr. Davis stated that he experimented several years in trying to get an improved strain of cucumber for forcing under glass and outside culture, and has finally fixed a "Perfect" type, combining quality, shape, color and productiveness. The cucumbers grow long and slim, sometimes measure 12 inches in length; the color is a rich, dark, glossy green, which they hold until nearly ripe, when they turn white without a sign of a yellow streak. It is very tender, brittle and of exceptional fine flavor. The seeds are very soft when ready for table use. This is an important feature. It will hold its color and brittleness long after cutting, and being a strong grower, is able to resist the cucumber disease. It is as early as the earliest strain of the White Spine Cucumber, and will outyield any other variety yet introduced. The seed which we furnish is grown especially for us by the introducer, and can be relied upon as being true. Pkt., 5c.; oz., 10c.; $1 / 4$ lb., 30c.; lb., $\$ 1.00$.

\section{NEW CUMBERLAND}

Is of the hardy, white spine type, a rapid and vigorous grower, and very prolific in fruit. The pickles differ from all other hardy sorts in being thickly set with fine spines over almost the entire surface. During the whole period of growth, from the time they first set until fully grown, the form is exceptionally straight and symmetrical, thus being as choice for slicing as for pickles. The flesh is firm, very crisp and tender at all stages. We offer it in full confidence that it will prove a valuable new pickling sort. Pkt., 5c.; oz., 10c.; 1/4 lb., 25c.; 1 lb., 80c.

\section{EARLY RUSSIAN}

This is the earliest. Fruits are small, being about three inches in length and one and a half inches in diameter. Plants productive and fruit of excellent quality. Pkt., 5c.; oz., 10c.; 1/4 lb., 25c.; lb., 90c.

\section{EVERBEARING}

This is a very early variety and extremely prolific. If the fruits are kept gathered, vines will continue on bearing throughout the season. The fruits, of a rich dark green color, average from four to five inches in length by an inch and a half in diameter. Owing to its great productiveness it is an excellent variety to plant for small pickles. Pkt., 5c.; oz., 10c.; 1/4 lb., 25c.; lb., 90c.

\section{IMPROVED WHITE SPINE}

An excellent variety, which produces an early crop of cucumbers. The fruits are straight, light green with white spines, and are crisp, tender and of good flavor. Pkt., 5c.; oz., 10c.; 1/4 lb., 25c.; lb., 90c. 


\section{CUCUMBERS-Continued}

\section{EARLY FORTUNE CUCUMBER}

Cucumbers of the "White Spine" type are most desirable on account of their attractive appearance and good quality. This new variety was originally discovered in a field of "Davis Perfect," and is now so thoroughly established that large fields do not show any variation either in plant or fruit. The cucumbers are slightly. longer than "Arlington White Spine," more cylindrical in shape, with very dark green skin and thick flesh, which is tender and crisp. A remarkable feature of this variety is the strong growth on the vines, which enables it to successfully withstand blight and bring the fruits to their full size and perfection. "Early Fortune" Cucumber is one of the best that has been introduced in years, and will soon take the place of many old-time strains of White Spine Cucumber. EARLY CLUSTER

Slim form. Extra prolific, frequently setting in clusters of two and three. Fine for small pickles. If fruit is kept gathered, the vines will continue in bearing. Pkt., 5c.; oz., 10c.; 1/4 lb., 25c.; 1 lb., 80c. EARLY FRAME OR SHORT GREEN

A popular variety of medium size. Pkt., 5c.; oz., 10c.; 1/4 lb., 25c.; 1 lb., 80c.

WESTFIELD'S CHICAGO PICKLE

Very productive and of fine quality. Largely used by Chicago pickling houses. Pkt., 5c.; oz., 10c.; 1/4 lb., 25c.; 1 lb., 90c.

\section{IMPROVED LONG GREEN}

One of the most popular sorts for home gardens and in country districts for :home markets. Fruits are very long, often 12 inches, slender and uniformly dark green color. It is rather late maturing. The vines are very vigorous and fairly productive. The matured fruits are excellent and tender for table use, and both large and small can be used for pickling. Pkt., 5c.; oz., 10c.; 1/4 lb., 25c.; 1 lb., 90c.

COOL AND CRISP

This new cucumber is said to be the earliest of all pickling varieties and is one of the finest for slicing. Pkt., 5c.; oz., 10c.; 1/4 lb., 25c.; 1 lb., 90c.

\section{JAPANESE CLIMBING}

Fruit about ten inches long, thick and of fine flavor. "Skin dark green; flesh pure white. Can be grown on trellis or fences. Pkt., 5c.; oz., 10c.; $1 / 4$ lb., 40c.; 1 lb., \$1.25.

WEST INDIA GHERKINS

Used only for pickling. Pkt., 5c.; oz., 15c.; 1/4 lb., 40c.

NEW EMERALD

A new variety that retains all the good points of the White Spine. The flesh being peculiarly crisp and tender and of delicate flavor, makes it the best for slicing. Fruits set early and its vigorous vines abound in long, straight cucumbers of handosme appearance. Pkt., 5c.; oz., 10c.; $1 / 4$ lb., 30c.; 1 lb., $\$ 1.00$.

\section{NICHOLS' MEDIUM GREEN}

An excellent all-around cucumber. Unequaled as a pickling sort, the young fruit being very even in shape, deep in color and very crisp. For forcing and for slicing there is none better. Pkt., 5c.; oz., 10c.; $1 / 4$ lb., 25c.; 1 lb., 90c.

\section{BOSTON PICKLING}

This is a very productive variety that is extensively grown for pickling. The vines are vigorous. The fruits are bright green, of medium size, very smooth and symmetrical. The flesh is crisp and tender. Our seed is decidedly superior to much that is offered. Pkt., 5c.; oz., 10c.; 1/4 lb., 25c.; 1 lb., $80 \mathrm{c}$.

\section{KLONDIKE}

A medium early, white spined cucumber of handsome, very dark green color and of excellent quality for slicing. The vines are very hardy and productive. The fruits, when mature, are often about eight inches in length, sometimes longer, and are uniform in shape and size. The color is dark green, slightly striped at the ends. The dark green color is retained much longer and is affected less by the hot sun than any other sort with which we are familiar. Its uniform shape and size and splendid color are making this variety very popular as a shipping sort. Pkt., 5c; oz., 10c.; 1/4 lb., 30c.; 1 lb., $\$ 1.00$.

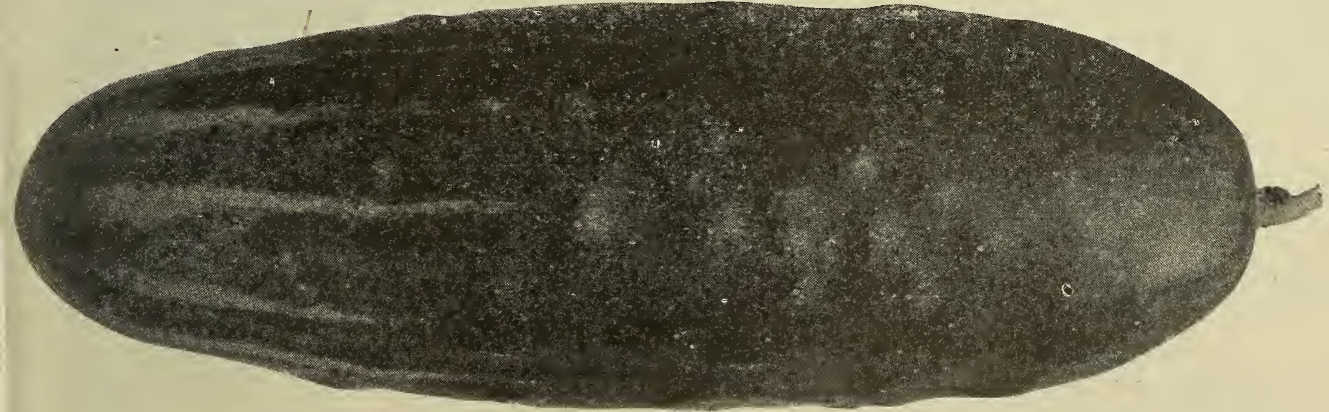




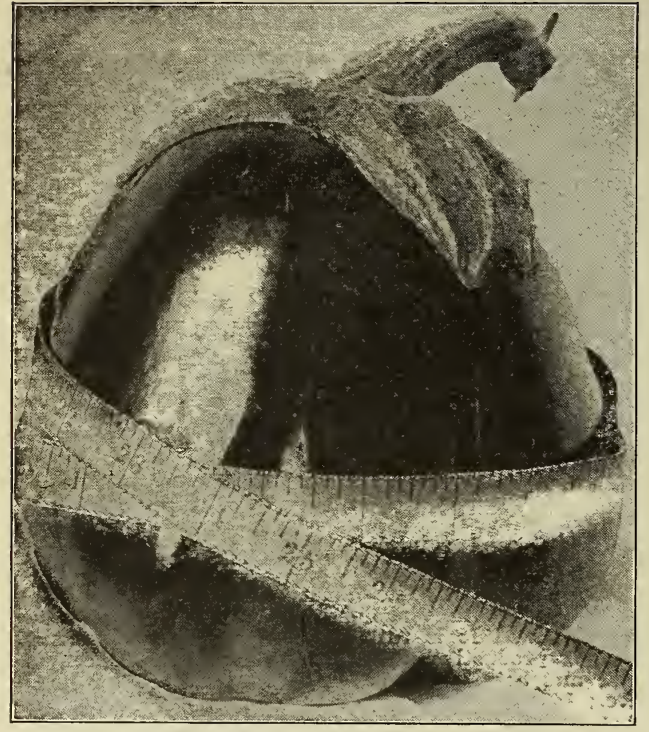

Improved New York Spineless Egg Plant

\section{EGG PLANT}

Egg plant seed germinates slowly and should be started in hotbed; for in this, as in all subtropical plants, it is of importance to secure a rapid growth from the first, the plants never recovering from a check received when young. When the plants have formed two rough leaves, transplant to three or four inches apart. When the ground is warm and all danger, not only from frost, but from cold nights is past, harden off the plants by gradual exposure to the sun and air and decreasing the supply of water, then carefully transplant to the open ground, setting the plants two and one-half feet apart. If needed, shade the young plants and protect them from the potato bug, which otherwise of ten destroys them. Some seasons Egg Plant will fail to set fruit, no matter how carefully they have been tended to. This is especially likely to happen if the summer is cool and rather moist. We know of no remedy for it, although it is a good practice to pinch off the ends of the branches after the plants begin to bloom, so that not more than two or three fruits will set. It is best to shade the plants when young from the hot sun.

\section{WHITE PEARL}

Fruit large and pure white; a decided acquisition. Pkt., 5c.; oz., 25c.

\section{IMPROVED NEW YORK SPINELESS} (See Illustration

This is an entirely spineless strain of the large purple-fruited, which is the well known standard. The plants are equally as productive, fruits as large and well colored, but stems and calyx are entirely free from spines. Pkt., 5c.; oz., 25c.; 1/4 lb., 90c.

\section{EARLY LONG PURPLE}

This is one of the earliest varieties and most productive. Pkt., 5c.; oz., 25c.

\section{BLACK PEKIN}

Very early; nearly round; jet black, and nearly smooth. The flesh is white and of fine quality. Pkt., 5c.; oz., 25c.

\section{CRESS}

\section{CURLED OR PEPPERGRASS}

Used for salad. Of pungent taste. Pkt., 5c.; oz., 10c.; 1/4 lb., 20c.

\section{WATERGRESS}

Sow seed along margin of running streams or ponds, cover lightly. Pkt., 10c.; oz., 36c.

\section{COLLARDS}

\section{GEORGIA OR CREOLE}

This is the one that is used so extensively in the south for greens. Forms a large open head. Pkt., 5c.; 0z., 10c.; $1 / 4$ lb., 30c.; 1 lb., \$1.00.

\section{CHICORY}

The roots, dug in the fall, dried, cut in thin slices, roasted and ground, are used largely as a substitute for coffee. Pkt., 5c.; oz., 10c.; 1/4 lb., 25c.

\section{ENDIVE \\ MOSS CURLED \\ (See Illustration}

A beautiful curled variety, somewhat resembling moss. Dark green in color. Quality fine. Pkt., 5c.; oz., 15c.; $1 / 4$ lb., 35c.

\section{BROAD-LEAVED BATAVIAN}

Heads large, leaves broad and thick; used for flavoring soups; inner leaves make a fine salad. Pkt., 5c.; oz., 15c.; 1/4 lb., 35c.

\section{WHITE CURLED}

For early use; to be used when young. Leaves pale green. Pkt., 5c.; oz., 15c.; $1 / 4$ lb., 35c.

$$
\text { GARLIC }
$$

A bulbous rooted plant for flavoring soups, stews, etc. Sets, lb., $40 c$.

\section{GOURDS \\ ORNAMENTAL}

Fine and curious. Very valuable for covering old trees, fences, etc. Fancy Mixed, pkt., 5c.; Dipper, pkt.. 5c.; Japanese Nest Egg, pkt., 5c.

\section{KALE, or DORECOLE \\ DWARF CURLED SCOTCH}

Is very : dwarf and spreading. The leaves are beautifully curled and of a bright green color. Hardy. Will remain out over winter in any place where the temperature does not fall below zero. A decided improvement upon the old Scotch. Pkt., 5c.; oz., 10c.; $1 / 4$ lb., 35c.

\section{KOHL RABI}

\section{EARLY WHITE VIENNA}

Smooth, excellent for forcing, and of fine quality. Pkt., 5c.; oz., 15c.; 1/4 lb., 45c.

\section{LEEK \\ LARGE AMERICAN FLAG}

This is a strong growing variety, producing large, thick stems of sweet flavor, when properly balanced. Pkt., 5c.; oz., 10c.; 1/4 lb., 30c.

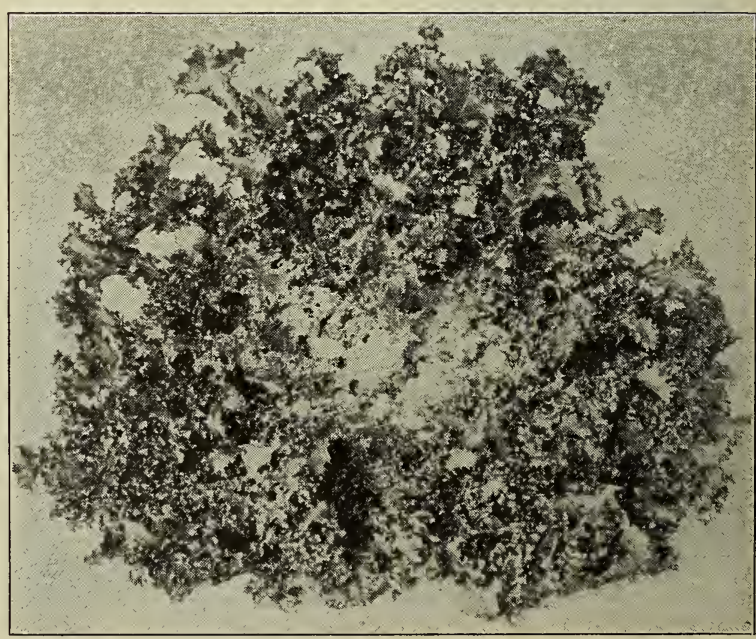

Moss Curled Endive 


\section{LETTUCE}

Probably no vegetable is more universally used than Lettuce, and to be thopoughly appreciated it must be brought to the table fresh and unwilted. The quality of Lettuce depends largely upon a rapid and vigorous growth. Sow in hotbed in March and in open ground as early as it can be worked, thinly in drills one foot apart. For a succession sow every three weeks during the season. The soil should be rich and mellow. Thin out plants as they grow.

\section{Loose Leaf Sorts \\ EARLY CURED SIMPSON}

An early variety of the best quality. Leaves beautifully crimpled, very tender and crisp, of a dark green color. Pkt., 5c.; oz., 10c.; $1 / 4$ lb., 20c.; lb., 75c.

\section{BLACK SEEDED SIMPSON}

An early variety of very best quality. Very popular among market gardeners. The leaves are more of a compact mass than a head. Very tender and of fine quality. Pkt., 5c.; oz., 10c.; 1/4 lb.. 30c.; lb., \$1.00.

\section{GRAND RAPIDS}

This variety undoubtedly stands at the head of the list for forcing, being a quick grower and not liable to rot. The plant is upright and forms loose heads of light green color. Pkt., 5c.; oz., 10c.; 1/4 lb., 30c.; lb., $\$ 1.00$.

\section{EARLY CURLED SILESIA}

A leading early curled sort. Very crisp and tender. Pkt., 5c.; oz., 10c.; $1 / 4$ lb., 25c.; 1 lb., $\$ 1.00$.

\section{EARLY PRIZE HEAD}

Leaves green and red. Very thin, crisp and tender. One of the best for private use. Pkt., 5c.; oz., 10c.; $1 / 4$ lb., 25c.; 1 lb., $\$ 1.00$.

\section{Splendid Butter-head Lettuce MAY KING}

A new variety from Germany, where it is a great favorite. It is very early and, being hardy, will stand considerable cold, damp weather, It can be planted out of doors or under glass, and in either case will produce fine, solid heads much sooner than any other variety. The outer leaves are yellowishgreen tinged with brown, while inside it is rich golden yellow. Pkt., 5c.; oz., 15c.; 1/4 lb., 50c.

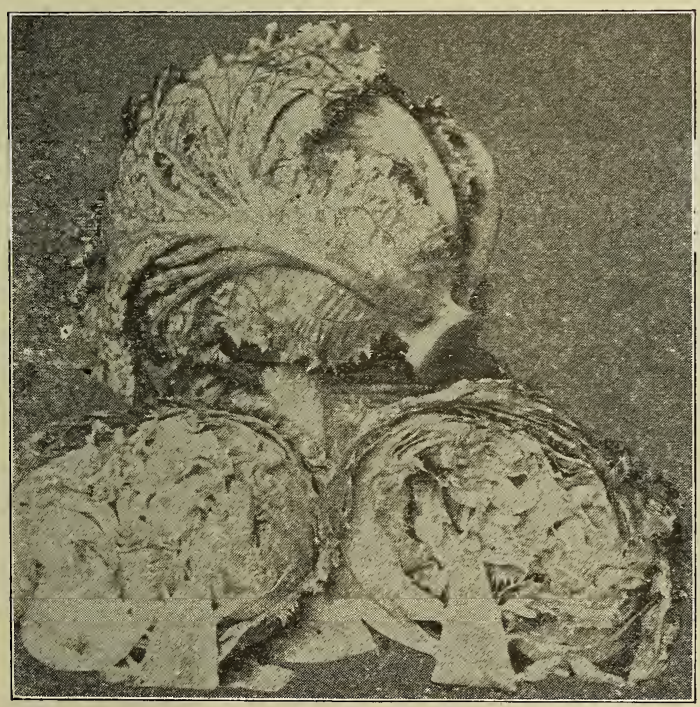

Denver Market Lettuce

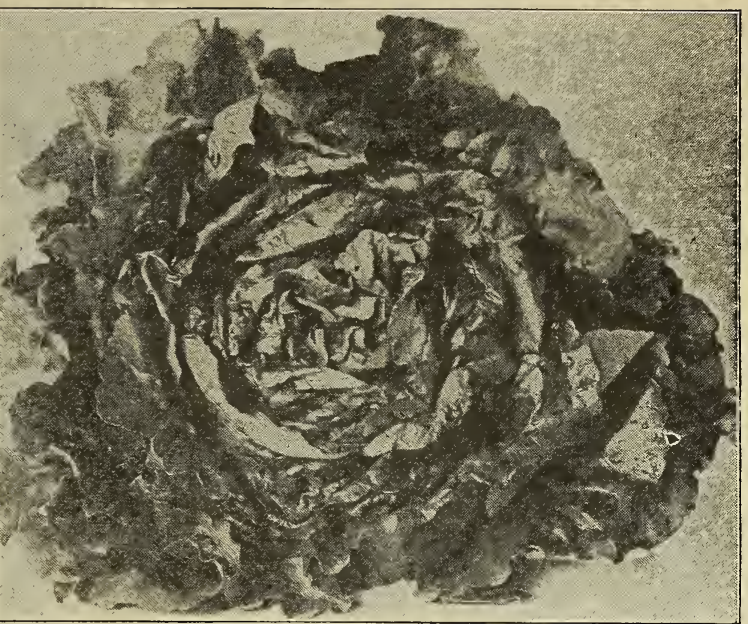

Big Boston Lettuce

\section{MAMMOTH BLACK SEEDED BUTTER}

An outdoor variety. Excellent in flavor. Pkt., 5c.; oz., 10c.; $1 / 4$ lb., 30c.; lb., $\$ 1.00$.

\section{YELLOW SEEDED BUTTER}

Dense yellow heads. Crisp and tender. Pkt., 5c.; oz., 10c.; 1/4 lb., 30c.; 1 lb., \$1.00.

\section{TENNIS BALL}

Close, hard, well-formed heads. Leaves green, thick, crisp and tender. One of the earliest. Extremely hardy and well adapted both for forcing and outdoor culture. Pkt., 5c.; Oz., 10c.; 1/4 lb., 30c.; $1 \mathrm{lb} ., \$ 1.00$.

\section{BIG BOSTON}

This variety is identical in color, shape and general appearance with the famous Boston Market Lettuce, but is double the size. It is about one week later in maturing, but its solidity and greater size of head will make it a most valuable sort. A desirable variety for forcing in cold frames, or open ground

planting. The "Big Boston" is sure to be wanted by the market gardeners and truckers, because it always produces large, solid, salable heads, and will commend itself to amateurs because it heads up well in all seasons of the year, and is of crisp, tender quality. Price: Pkt., 5c.; oz., 10c.; $1 / 4$ lb., 30c.; lb., $\$ 1.00$.

\section{Fine Crisp-Head Lettuces}

\section{DENVER MARKET}

Best Early Lettuce for Outdoor Cultivation. This is an early variety of head lettuce for either forcing or open ground culture. It forms large, solid heads of good, light green color, and is very slow to go to seed. The leaves are beautifully crimpled like Savoy Cabbage, and very crisp and tender. Excellent flavor. The heads resemble the Hanson, but are more oblong. Pkt., 5c.; oz., 10c.; $1 / 4$ lb., 30c.; 1 lb., \$1.00.

\section{IMPROVED HANSON}

A popular lettuce that produces very hard heads. The heads are green outside and white within. It is tender, crisp and of fine flavor. One of the best for garden culture. Pkt., 5c.; oz., 10c.; 1/4 lb., 30c.; 1 lb., $\$ 1.00$. 


\section{MUSK IIELONS OR CANTALOUPES}

The variety of Melons covers such a large field that it is difficult to point out any particular sort and say it is the best, as some of us prefer a small melon or a yellow-fleshed sort, while others fancy a large or a green-fleshed variety. We have done the best possible, and have carefully selected the finest variety of each type, and leave it to your taste to choose the one nearest your ideal, and we are quite sure you will make no mistake no matter which sort you select. Large packets, 5 cents each.

\section{TIP TOP}

\section{(See Illustration)}

Tip Top in Quality-Tip Top in Appearance-Tip Top in Productiveness. - Its appearance on the market is very attractive and sells on sight. Gardeners tell us that their customers soon learn to pick them out, and will have no other kind. Flesh yellow, firm, but not hard, sweet and juicy. Eatable to the very outside coat. It is unexcelled for productiveness. Oz., 15c.; 1/4 lb., 40c.; lb., \$1.50.

\section{DAVIS' GRAND}

\section{(See Illustration)}

The fruit is about six inches in diameter, slightly elongated, and slightly ribbed. Color a peculiar peagreen with netting a lighter shade. The flesh is thick, having a small seed cavity, and is firm, fine grained, of a rich salmon or red color. 'In flavor it even surpasses the best grown Emerald Gem. The flesh extends to the rind and retains its color and quality to the outer shell, and the shell, which, though thin, is very hard and firm, and because of this keeps and bears shipment remarkably well. We know of no other salmon-fleshed variety so desirable for the shipper, home or market gardener. Oz., 15c.; 1/4 lb., 50c.

\section{BURRELL'S GEM}

A splendid salmon-fleshed melon for shipping. Of delicious, sweet flavor. Has dark green skin, slightly ribbed and closely netted. Oblong in shape with rounded ends. Average fruit six inches long by about four inches deep. Thin, tough rind. Oz., 10c.; 1/4 lb., 25c.; lb., 80 c.

\section{HOODOO}

Has an exceptionally dense and fine netting, which practically extends over the entire surface. The flesh is very thick, highly colored, and of finest texture and flavor. The rind is thin, but firm, so that the melons may be shipped long distances and still maintain a perfect condition. Oz., 10c.; 1/4 lb., 30c.; $1 \mathrm{lb}$., $\$ 1.00$.

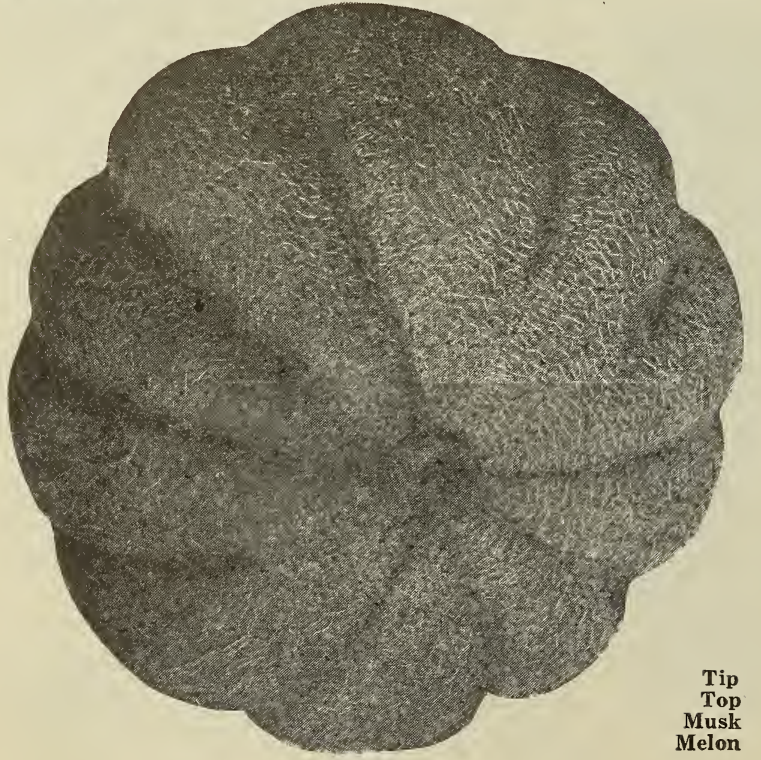

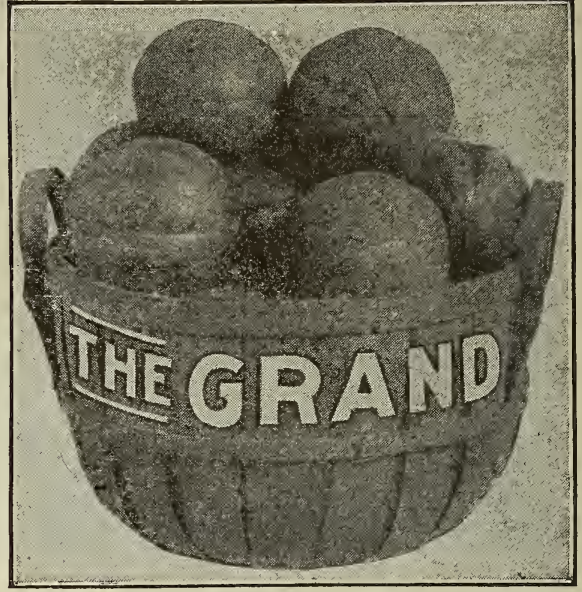

Musk Melon

\section{EARLY HACKENSACK}

Ripens usually in about 70 days. The melons are of good size, almost of the same weight as the late Hackensack, heavily ribbed and netted, and their. flesh is thick and of fine flavor. A splendid melon for the market and for shipping. Early and a wonderful yielder. Ptk., 5c.; oz., 10c.; 1/4 lb., 25c.; 1 lb., 75c.

\section{OSAGE}

This melon in many sections is the favorite salmonfleshed variety. It grows large, oval, slightly ribbed and netted; skin is very dark green. Flesh is very thick and sweet flavored, most delicious to the rind. The whole erop is very even and fruit extra heavy, owing to this thickness of the flesh. A great favorite for both market purposes and the home garden especially. Pkt., 5c.; oz.. 10c.; 1/4 lb., 30c.; 1 lb., $\$ 1.00$.

\section{ROCKYFORD}

This variety is of the Netted Gem type and has been improved at Rockyford, Colorado, a section noted for fine musk melons. The melons average about five inches in length, and are of most delicious flavor; flesh is smooth-grained and light green colored. It is a very popular variety, and the melons are found on the tables of all the leading hotels and restaurants during their season. Pkt., 5c.; oz., 10c.; $1 / 4$ lb., 30c.; 1 lb., $\$ 1.00$.

\section{EMERALD GEM}

One of the sweetest melons in cultivation; smooth skin, deep salmon-colored flesh; early and plofiific. On account of its fine quality this is one of the finest melons for the home garden. Pkt., 5c.; oz., 10c.; 1/4 lb., 30c.; 1 lb., $\$ 1.00$.

\section{PAUL ROSE}

A cross between Netted Gem and Osage. Flesh salmon color. Pkt., 5c.; oz., 10c.; 1/4 lb., 30c.; 1 lb., \$1.00.

\section{JENNY LIND}

An extra early green flesh variety. Fine quality. Pkt., 5c.; oz., 10c.; 1/4 lb., 25c.; 1 lb., 90c.

\section{PRINCESS OR IDEAL}

An early large-sized, salmon-colored flesh of fine quality. Pkt., 5c.; oz., 10c.; $1 / 4$ lb., 25c.; $1 \mathrm{lb}$, , 80c. 


\section{WATERIMELONS}

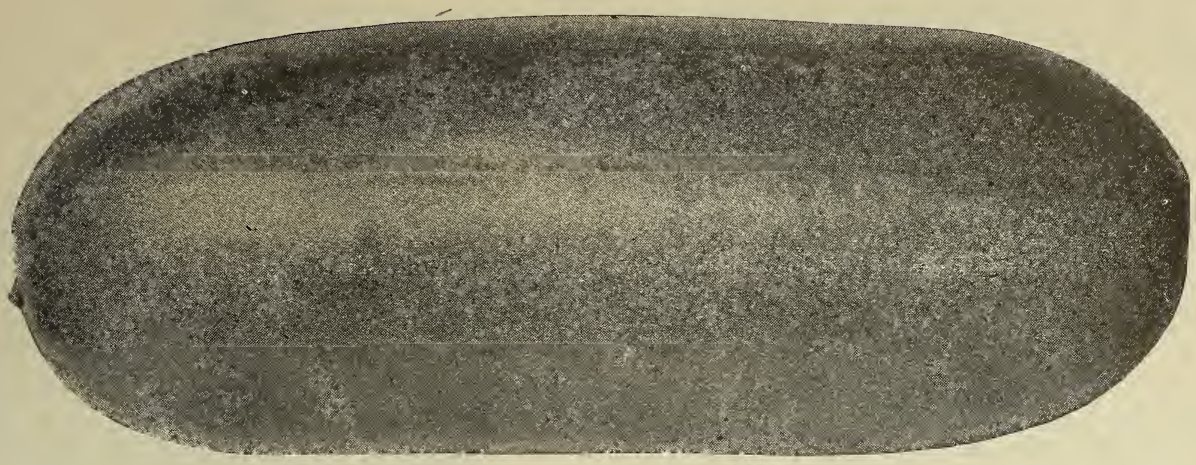

Tom Watson Watermelon-Finest for Home Garden and Shipping

One ounce of seed for 30 hills, 1 to 2 pounds to the acre.

A light, sandy soil with good exposure to the sun is best for watermelons. It should be prepared deep, but receive shallow cultivation. Hoe often and thoroughly. If extra large melons are desired for exhibition purposes, leave but one or two melons on a vine. Plant in hill 8 to 10 feet apart each way, with a shovel of well rotted manure mixed with the soil in each hill. If commercial fertilizer is used it should contain a large percentage of ammonia and potash. Plant 8 to 10 seeds in each hill, and finally, when danger from insects is past, leave but three strong plants.

\section{TOM WATSON}

\section{(See Illustration)}

A large oblong melon, the skin of which is dark green, with thick netting all over; quite distinct from other varieties. It originated in Georgia, a state noted for producing fine Watermelons; and this new variety is a good example of what a good, first-class Watermelon should be. The rind is thin, but tough; and the flesh a bright, attractive red color, of a delicious sweet and satisfying flavor. Its appearance and quality strongly recommend it both for home use and for market. Pkt., 5c.; oz., 10c.; $1 / 4$ lb., 20c.; lb., 60c.

\section{COLE'S EARLY}

Extremely delicate in texture of flesh, which is a dark red, rind green, striped with lighter shade, thin, very brittle; medium size, round; comes early. Sure cropper. Pkt., 5c.; oz., 10c.; 1/4 lb., 20c.; lb., 60c.

\section{KLECKLEY'S SWEET}

Unsurpassed for home use or near markets. Vine vigorous and productive; fruit of medium size, oval; color dark green, often showing fine russeting; flesh very bright, rich red and exceedingly sweet. So crisp and tender it will not stand shipping, the fruit bursting open if subject to even a slight jar, or when the rind is penetrated with a knife. Pkt., 5c.; oz., 10c.; $1 / 4$ lb., 20c.; lb., 60c.

\section{SWEET HEART}

An entirely new and distinct watermelon, which is an extremely large, handsome, heavy, good shipper and long keeper. Bright color and of best quality. Carloads of Sweet Hearts were sold at fancy prices when no others were salable. Vine vigorous and productive, ripening its fruit early. Fruit large, oval, heavy, uniformly mottled light and dark green; rind thin, but firm; flesh bright red, firm, solid, very sweet and tender. A mood keeper. Pkt., 5c.; oz., 10c.; $1 / 4$ lb., 20c.; 1 lb., 55c.

\section{DIXIE}

Beautifully striped. Is surpassed by few, if any, for shipping or for table. Flesh very red, sweet, and juicy; all that can be desirable in quality, flavor, etc. Will hold after it is ripe for several days and still retain its excellent quality. Pkt., 5c.; oz., 10c.; $1 / 4$ lb., 20c.; 1 lb., 50c.

\section{GEORGIA RATTLESNAKE}

Excellent market variety; large, oblong; rind dark mottled and striped; a well-known shipping melon. Pkt., 5c.; oz., 10c.; 1/4 lb., 20c.; lb., 60c.

\section{KOLB'S GEM}

Uniform round, marbled delicately with light shades, and often attains the weight of forty pounds. Flesh bright red, and of excellent flavor. Unsurpassed as a shipper. Pkt., 5c.; oz., 10c.; 1/4 lb.. 20c.; 1 lb., 50c.

\section{ICE CREAM}

Medium size, oval-shaped. Flesh scarlet, solid, very sweet and of fine quality. One of the best. Pkt., 5 c.; oz., 10c.; 1/4 lb., 20c.; 1 lb., 55c.

\section{FLORIDA FAVORITE}

A new early melon. Very large, sweet, and of a fine flavor. Pkt., 5c.; oz., 10c.; $1 / 4 \mathrm{lb}$., 20c.; 1 lb., 60c.

\section{CITRON}

For preserves only. Pkt., 5c.; oz., 10c.; 1/4 lb., 20c.; 1 lb., 50c.

\section{CUBAN QUEEN}

A large, mottled green, round variety. Red fleshed, solid, fine quality. Pkt., 5c.; oz., 10c.; 1/4 lb., 20c.; 1 lb., 50c.

\section{FORDHOOK EARLY}

Has proved to be the largest early variety on the list. From seed planted May 10th ripe melons were produced the last of July. The rind is tough, making it valuable for shipping. Color is a uniform, medium green; flesh red and very sweet. Pkt., 5c.; oz., 10 c.; 1/4 lb., 25c.; 1 lb., 75c.

\section{PHINNEY'S EARLY}

Of medium size, very early and productive. Flesh pink, very solid, and of fine flavor. Can be grown farther north than most sorts. Pkt., 5c.; oz., 10c.; $1 / 4$ lb., 20c.; 1 lb., 50c. 


\section{ONIONS}

A strong. deep, rich soil is best suitable for onions. Rich beds, well drained, give a very large yield. The ground should be heavily dressed with well rotted manure (fifteen cords per acre would be none too much) and plowed a moderate depth, taking a narrow furrow in order to thoroughly mix the manure with the sod. Early in the spring, after the soil has been thoroughly pulverized, sow thinly four or five pounds to the acre, in drills fourteen inches apart. When well started (say four inches high) thin out to stand three inches apart in the drills. Keep the ground well hoed and free from weeds, but do not ridge up to the growing bulbs.

\section{SOUTHPORT YELLOW GLOBE}

\author{
(See Illustration)
}

This is similar in size and form to the Large White Globe, but has a pale straw-yellow skin. The bulbs are large in size, more perfectly globe-shaped than the Globe Danvers, but later in ripening. It is an excellent keeper and of mild flavor. A heavy cropper, and, owing to its handsome appearance and delightful flavor, sells readily in all markets. Pkt., 5c.: oz., 20c.; $1 / 4$ lb., 70c.; 1 lb., $\$ 2.50$; by express, 5 lbs. or over, $\$ 2.40$ per $1 \mathrm{lb}$.

\section{SOUTHPORT LARGE RED GLOBE}

This strain of Red Globe Onion which we offer is far superior to that usually sold at the present time as it produces splendid, globe-shaped bulbs of handsome appearance and the best keeping qualities. There is probably no other red variety which commands a higher price on the market, as the rich purplish crimson color makes it exceedingly attractive. The flesh is solid, fine grained, mild and tender. In addition to being a most beautiful onion, it matures early in the season, which is a decided advantage to market gardeners. Pkt., 5c.; oz., 20c.; $1 / 4$ lb., 60c.; lb., $\$ 2.10$; by express, 5 lbs. or over, $\$ 2.00$ per $1 \mathrm{~b}$.

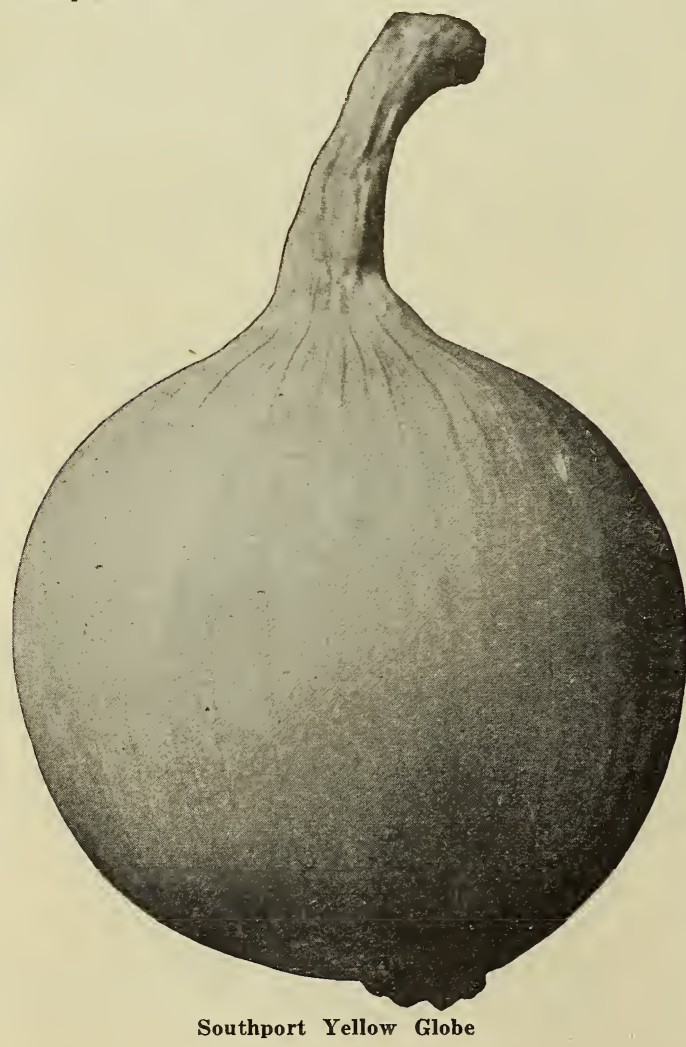

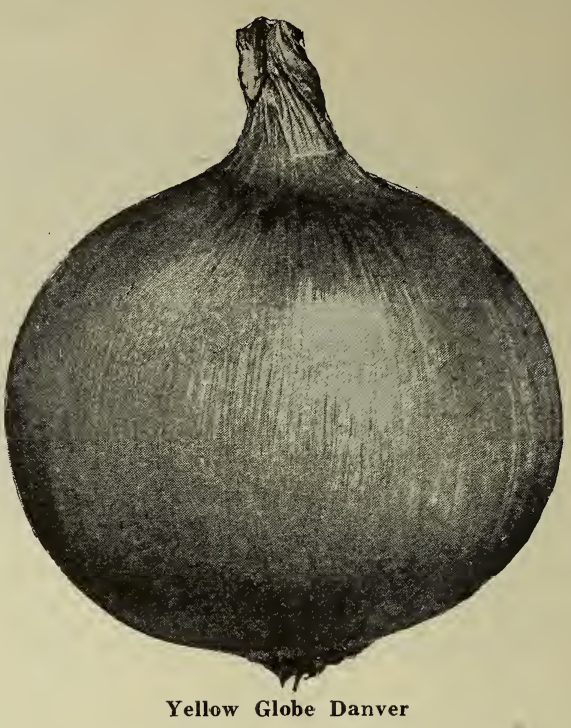

\section{YELLOW GLOBE DANVERS}

One of the most extensively used main crop yellow onions for the home garden and market. The bulbs are of medium to large size, uniformly globe shaped, with small neck, and ripen very evenly. The skin is rich coppery yellow. The flesh is creamy white, crisp and of mild and excellent flavor. The variety keeps very well and is excellent for shipping. We have by careful selection and breeding developed a strain which has the ripening habit and small neck of the original Danvers, and yet is more globular, thus giving larger yields and handsomer bulbs without sacrificing any of the good qualities of the original Danvers. Pkt., 5c; oz., 20c; 1/4 lb., 60c; 1 lb., $\$ 2.25$; by express, 5 lbs. or over, $\$ 2.10$. per $\mathbf{l b}$.

\section{SOUTHPORT WHITE GLOBE}

This strain is thoroughly first-class in every part:cular, and will produce handsome, globe-shaped bulbs that are solid and of splendid quality. A good keeper, Pkt., 5c.; oz., 30c.; 1/4 lb., \$1.00; 1 lb., $\$ 3.75$; by express, 5 lbs. or over, per lb., $\$ 3.50$.

\section{RED WETHERSFIELD}

This is the standard market variety over a large section of the country, though a milder flavored bulb is preferred in some of the eastern cities. The bulbs grow to large size, and while flattened in form are quite thick through. Thin neck and flattened form insure thorough ripening and good keeping qualities. The skin is a deep purplish red, while the white flesh is slightly tinted with pink in rings. Immensely productive. Pkt., 5c.; oz., 20c.; 1/4 lb., 6 cc.; 1 lb., $\$ 2.25$; by express, 5 lbs. or over, $\$ 2.10$ per $l b$.

\section{WHITE PORTUGAL}

Alco called Philadelphia White Silver Skin. The kulls grow to good size, ripening early and quite evenly. The flesh is mild and sweet; the thin skin a clear silvery white; of handsome appearance if the bulbs are gathered soon as ripened, carefully dried under shelter away from the strong sunlight. When seed is sown at the rate of twenty-five pounds per acre, it makes bulbs of suitable size and most desirable for pickling. Pkt., 5c.; 1 oz., 20c.; $1 / 4$ lb., $75 \mathrm{c}$. 


\section{ONIONS-Continued}

\section{PRIZETAKER}

An enormous globular onion. Skin of a rich yellow color. Flesh white, mild and tender. It is very hardy and a good winter keeper. Pkt., 5c.; oz.. 20c.; $1 / 4$ lb., 60c.; lb., $\$ 2.00$; by express, 5 lbs. or over, $\$ 1.80$ per $l b$.

\section{YELLOW DUTCH OR STRATSBURG}

Bulbs quite flat and of good size. Skin rich yellow, turning to brown when exposed. Ripens early. Flesh white and of mild flavor. Keeps well. It is one of the very best to grow for sets-a set being neither more nor less than a small well-ripened onion. Pkt., 5c.; oz., 20c.; 1/4 lb., 60c.; lb., \$2.25; by express, 5 lbs. or over, $\$ 2.10$.

\section{ROUND WHITE SILVERSKIN}

A handsome onion of mild flavoring. Good keeper. Largely grown for pickles. Pkt., 5c.; oz., 15c.; 1/4 lb., 40c.; lb., \$1.50.

\section{MAMMOTH SILVER KING}

A very large flat variety, white, of mild flavor and beautiful form. Pkt., 5c.; oz., 15c.; 1/4 lb., 40c.; lb., \$1.50.

\section{ONION SETS}

Onion sets should be planted out as early as the ground is dry enough to work. Plant them in rows fourteen inches apart, with sets three inches apart. When raised from sets the onions can be used in the green state in June or they will be ripened off by July.

\section{WHITE}

Qt., 25c.; pk., 75c.; bu., $\$ 3.00$; bbl. of 4 bu., $\$ 11.50$.

\section{YELLOW}

Qt., 25c,; pk., 75c.; bu., \$2.75; bbl. of 4 bu., $\$ 10.75$.

\section{PERENNIAL OR WINTER}

Also called Egyptian and Tree Onions. May bet set out in the spring, but are usually set in the fall. Come up year after year without the slightest winter protection and produce the earliest spring onions. Qt., 25c.; pk., 40c.; bu., \$1.25.

Prices subject to market variation, and they are shipped at buyer's expense. If you want a large lot, write for prices. Price by the quart includes prepayment of postage (deduct $15 \mathrm{c}$ per quart if by express).

\section{OKRA, OR GUMBO}

\section{WHITE VELVET}

Of tall growth, with Iong pods, which are perfectly round, smooth, and of a velvety white appearance. Pkt., 5c.; oz., 16c.; 1/4 lb., 20c.; lb., 60c.

\section{MAMMOTH LONG POD}

Very prolific, with slender, long, green pods of best quality and most desirable color for canning. Pkt., 5c.; oz., 10c.; 1/4 lb., 20c.; lb., 60c.

\section{IIUSTARD}

\section{WHITE}

Grown for salads. The leaves are light green, mild and tender when young. Seed light yellow. Pkt., 5c; oz., 6c; 1/4 lb., 12c; lb., 30c.

\section{GIANT CURLED}

The true curled leaf variety so popular in the South. Plant in the fall to furnish an early spring salad. Pkt., 5c; oz., 10c; $1 / 4$ lb., 20c.

\section{PARSLEY}

\section{FERN LEAVED}

A beautiful sort. Very valuable for table decoration. Pkt., 5c; oz., 10c; 1/4 lb., 20c; lb., 70c.

\section{MOSS CURLED \\ (See Illustration)}

This is very ornamental in growth. The leaves are of a peculiar extra dark green color. It is very productive, and from the dense curled character of its leaves a quantity can be gathered in less time than with the more open-leaved varieties. - Pkt., 5c; oz., 10c; $1 / 4$ lb., 20c; lb., 60c.

\section{PARSNIPS}

One ounce to 200 feet of drill, 5 pounds per acre.

\section{HOLLOW CROWN}

The best for general use. Tender and sweet. Pkt., 5c; oz., 10c; 1/4 lb., 15c; $1 / 2$ lb., 28c; lb., 40c; by express, 5 lbs. or over, 25c per $1 \mathrm{~b}$.

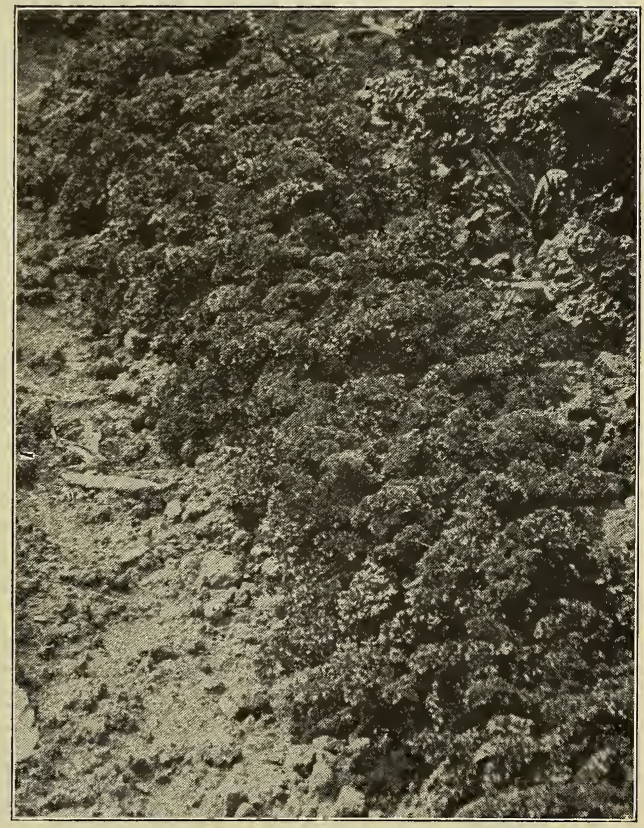

Moss Curled 


\section{PEAS}

One quart to 125 feet of drill, two and one-half bushels per acre. We do not pay the parcel post on pound lots or over of peas. Our four best peas for either the home or market gardener.

\section{SUTTON'S EXCELSIOR}

\section{(See Illustration)}

This handsome, new, early wrinkled pea is the largest podded of any dwarf variety on our list. It is also the most vigorous in growth of vine and is unsurpassed in quality. The pods mature very nearly as early as those of Nott's Excelsior, but are broader and with the foliage distinctly lighter green in color. We believe Sutton's Excelsior will soon be recognized as one of the most valuable dwarf sorts yet introduced. Pkt, 5c; $1 \mathrm{lb} ., 25 \mathrm{c} ; 3 \mathrm{lb} ., 60 \mathrm{c} ; 14 \mathrm{lb} ., \$ 1.75 ; 56 \mathrm{lb} ., \$ 6.50$.

\section{ALDERMAN}

(See Illustration)

This comparatively new pea is in many respects the very best early main crop variety of the valuable Telephone type. The vines grow nearly five feet high, are dark green. The peas are of largest size and unsurpassed in quality. Market gardeners are demanding the large podded, dark colored sorts which retain their fine appearance even after shipping a long distance. The Alderman answers these requirements and furthermore is the most productive of this class. We recommend it. Plst., 5 c; 1 lb., 25c; 3 lb., 60c; 14 lb., $\$ 1.65 ; 56$ lb., $\$ 6.25$.

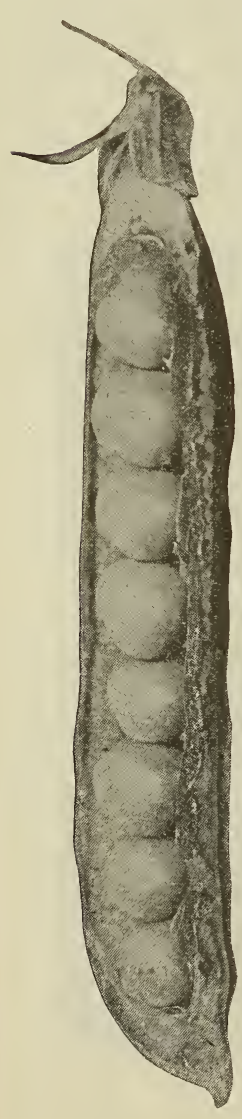

\section{THOMAS LAXTON}

A comparatively new variety of large podded pea. The plant is a very hardy and strong grower, producing extra large size pods in abundance. The quality is delicious and cannot be surpassed by any other variety. The "Thomas Laxton" will mature nearly as early as any of the extra early smooth Peas, and being a wrinkled sort is much sweeter. Pkt., 5c; 1 lb.,

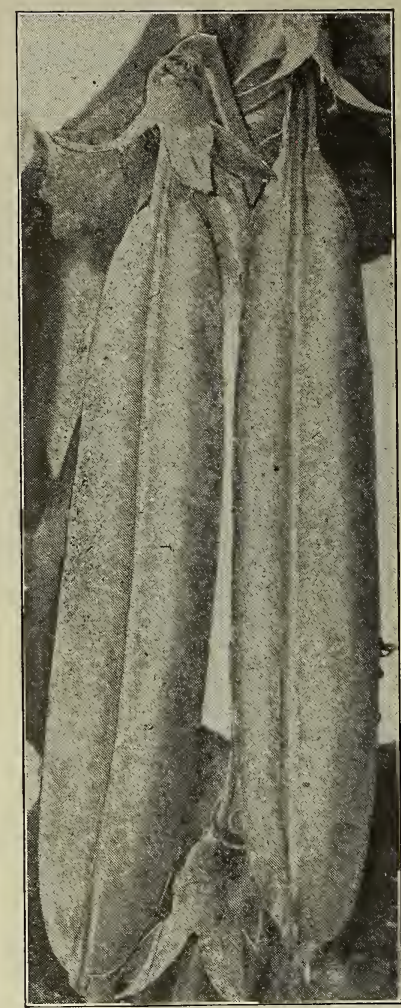

Sutton's Excelsior 25 c; 3 lb., 60c; 14 lb., \$1.75; 56 lb., \$6.75.

\section{GRADUS OR PROSPERITY}

An Extra Early Wrinkled Pea. The vine of this most distinct sort is like that of Davis' First in the Market, except that it grows a little taller and matures its pods a little later. The immense pods are as large as those of the Telephone, uniformly well shaped and handsome and more attractive than those of the other first earlies. They ripen slowly and continue fit for use much longer than most varieties, making this by far the most desirable sort for the home garden. The peas are very large, of splendid quality and beautiful color, which they retain after ecoking. Pkt., 5c; 1 lb., 25c; 3 lb., 60c; 14 lb., \$1.75; 56 lb., $\$ 6.75$.

\section{GREGORY'S SURPRISE OR ECLIPSE}

Is the earliest sweet wrinkled pea in cultivation, maturing in 49 days. This new extra early, wrinkled pea is a cross between Laxton's Earliest of All and American Wonder. It is as early as the ealriest of the hard peas and as heavy a cropper, while at the same time it possesses that peculiar sweetness which belong to the wrinkled varieties. The Surprise grows abouc 20 inches tall on rich garden soil and ripens very early. Like most of the early peas it succeeds when sown quite thickly. Pkt., 5c; 1 lb., 25c; 3 lb., 60c: 14 lb., $\$ 1.75 ; 56$ lb., $\$ 6.50$.

\section{AMERICAN WONDER}

The carliest of the dwarf, wrinkled varieties. The vines are about nine to twelve inches high and produce a good crop of well filled pods of medium size, about two and five-eights to two and three-fourths inches long, containing five to eight large peas which are exceedingly sweet, tender and well flavored. Seed medium sized, generally flattened, wrinkled and pale green. Pkt., 5c; 1 lb., 25c; $3 \mathrm{lb.,60c;15} \mathrm{lb.,} \$ 1.50 ; 60 \mathrm{lb.,} \$ 5.75$.

\section{NOTT'S EXCELSIOR}

The best very early, dwarf pea. It combines the good qualities of American and Premium Gem Peas. The vines are larger and more productive than American Wonder and earlier than Premium Gem and average about twelve inches high. The pods are medium sized, about two and three-fourths inches long. The peas, in sweetness and quality, are unsurpassed. Seed medium sized, wrinkled, green and somewhat flattened. A most desirable sort for the market gardener and unsurpassed for the home garden. Pkt., 5c; 1 lb. $25 \mathrm{c} ; 3 \mathrm{lb} ., 60 \mathrm{c} ; 15 \mathrm{lb} ., \$ 1.60 ; 60 \mathrm{lb} ., \$ 6.00$. 


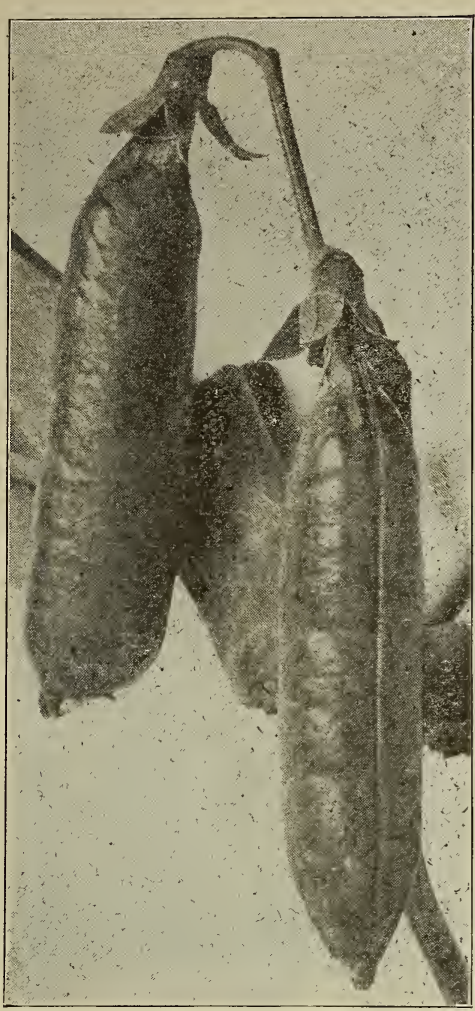

Little Marvel
PEAS-Continued

\section{LITTLE MARVEL}

(See Illustration)

Still another year's experience makes us hold this distinct new dwarf first-early in ever higher esteem. We are sure as soon as the American gardeners, whether for pleasure or profit, become acquainted with Little Marvel they will drop both Little Gem and Nott's Excelsior, popular as these two varieties are today. The vines of dwarf even growth average fifteen inches in height and are heavily set with fine pods, frequently borne in pairs. The pods average two and one-half inches in length, are square at the bottom and well filled with six to seven quite large, deep green peas. The peas are fully as early as the American Wonder or Nott's Excelsior while the vines produce much heavier crop and the pods are larger. All who desire a fine crop of the choicest early peas of the wrinkled sort will be delighted with Little Marvel. Pkt., 5c; 1 lb., 25c; 3 lb., 65c; 14 lb., $\$ 2.00$.

\section{DWARF DEFIANCE}

A new variety of great value, growing fifteen to eighteen inches high. Very large pods, measuring up to six inches in length. Vines and pods are a rich, dark green, and pods contain eight to nine immense peas. The plant is a vigorous grower, the pods being borne in pairs. It is a great producer and the quantity of peas which shell out is surprising. One of the most promising new varieties. Pkt., 5c; 1 lb., 25c; $3 \mathrm{lb.,60c;15} \mathrm{lb.,} \$ 1.50 ; 60$ lb., $\$ 5.75$.

\section{MELTING SUGAR}

Pods). We consider this the the edible-podded sorts, in which the pods are used when half grown and are cooked in the same way as snap beans. The pods Melting Sugar are very large, four to four and one-half inches long, broad, often curved or twisted, and when young, stringless, very tender and finely flavored. The variety we offer, sometimes called Mammoth Melting Sugar, is rather late maturing, very prolific, strong growing, about four to five feet high, with large light colored foliage. Seed medium to large, smooth, round, light yellowish white in color. Pkt., 5c; 1 lb., 25c; 3 lb., 65c; 15 lb., 2.00; 60 lb., $\$ 7.75$.

PREMIUM GEM

(Improved Little Gem.) A desirable early green wrinkled dwarf variety similar but better than McLean's Little Gem. The vines are very productive, fifteen to eighteen inches high. The pods are of medium size, about two and three-fourths long, crowded with six to eight large peas of tine quality. Seed green, large, wrinkled, often flattened. Pkt., 5c; 1 lb., 25c; 3 lb., 60c; 15 lb., $\$ 1.50 ; 60$ lb., $\$ 5.75$.

\section{ALASKA}

An extra early round pea, pods of dark green, height 2 feet. Pkt., 5c; 1 lb., 20c: 3 lb., 40c; 15 lb., $\$ 1.40 ; 60$ lb., $\$ 5.25$.

\section{DAVIS' FIRST IN THE MARKET}

The longest podded, more peas in pod, and larger number of pods to the vine than any other extra early. It blooms two days later than Maud S., and in the development of pods suitable for picking in three or four days later; it will yield 30 to 50 per cent more than any other strain of Extra Earlies. A desirable pea for the market gardeners, as their larger size and the fine quality will make them a general favorite. Pkt., 5c; $1 \mathrm{lb} ., 20 \mathrm{c} ; 3 \mathrm{lb} ., 50 \mathrm{c} ; 15 \mathrm{lb} ., \$ 1.40 ; 60 \mathrm{lb} ., \$ 5.25$.

\section{EVERBEARING}

A prolific and continuous-bearing pea, giving it special value for both summer and autumn use; pods three to four inches long, containing six to eight large, wrinkled peas, of rich flavor, sweet and tender. Three feet. Pkt., 5c; 1 lb., 25c; 3 lb., 60c; 15 lb., $\$ 1.60 ; 60$ lb., $\$ 6.00$.

\section{DWARF TELEPHONE}

This is a dwarf variety, bearing large, handsome pods like Telephone; height, eighteen inches. Pkt., 5c; 1 lb., 25c; 3 lb., 60c; $15 \mathrm{lb}$., $\$ 1.60 ; 60 \mathrm{lb}$., $\$ 6.00$.

\section{IMPROVED STRATAGEM}

Pods of immense size, filled with very large dark green peas of the finest quality; height, eighteen inches. Pkt., 5c; 1 lb., 25c; 3 lb., 60c; 15 lb., $\$ 1.60 ; 60$ lb., $\$ 6.00$.

\section{CHAMPION OF ENGLAND}

One of the best known of the older varieties; a tall-growing, green wrinkled marrow ; quality unsurpassed; pods medium; peas large. Five feet. Pkt., 5c; 1 lb., 25c; 3 lb., $60 \mathrm{c} ; 15 \mathrm{lb} ., \$ 1.50 ; 60 \mathrm{lb} ., \$ 5.75$.

\section{TELEPHONE}

The favorite late variety for the market gardener. Extra large pods. This pea has proved to be a most valuable introduction. Vine large, coarse leaves, height about four feet. The pods are very large and filled with immense peas, which are largest of any. Tender, sweet and of spelndid cuality and flavor. The stock we offer has been selected with every care and will give satisfaction to the most exacting grower. Pkt., 5c; 1 lb., 25c;3 lb., 60c; 15 lb., \$1.50; 60 lb., \$5.75.

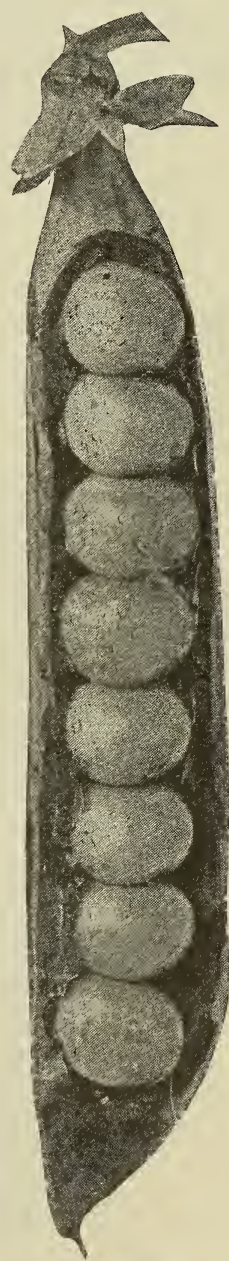

Telephone 


\section{PEPPERS}

Sow seeds in flats under glass in March; set out in other flats when two or three inches high; two inches apart each way; and when the weather has become thoroughly settled in spring and danger from belated freezes is over, transplant in open ground in warm, very rich and well prepared soil, making the rows two to three feet apart, with plants 15 to 18 inches apart in the rows. The large sweet sort; have become very popular and are always in large demand. One ounce will produce 1500 plants.

\section{RUBY KING}

\section{(See Illustration)}

The largest and handsomest of all red peppers. It is very bright colored, of mild flavor and is excellent for stuffed pickles. Pkt., 5c; oz., 15c; 1/4 lb., 40c.

\section{CHINESE GIANT}

Double the size of Ruby King. This is the standard large Sweet Pepper. It is quite early to ripen and very productive for such a large variety. Productiveness may be increased by pinching the first or King blossoms that appear. Pkt., 5c; oz., 35c.

\section{BULL NOSE or LARGE BELL}

The standard sweet-flavored sort. Plants two feet in height; prolific and quite early in ripening. Sweet scarlet fruits, three inches in length and two inches in diameter. Earlier than Ruby King. Pkt., 5c; oz., 25c.

\section{RUBY GIANT}

A variety of Mango Pepper which is of a desirable size for stuffing. A cross of the Ruby King and Chinese Giant. Grows to a large size. Pkt., 5c; oz., 35c.

\section{CELESTIAL}

When growing Peppers are a creamy yellow color turning to a deep scarlet when ripe. Pkt., 5c; oz., $35 c$.

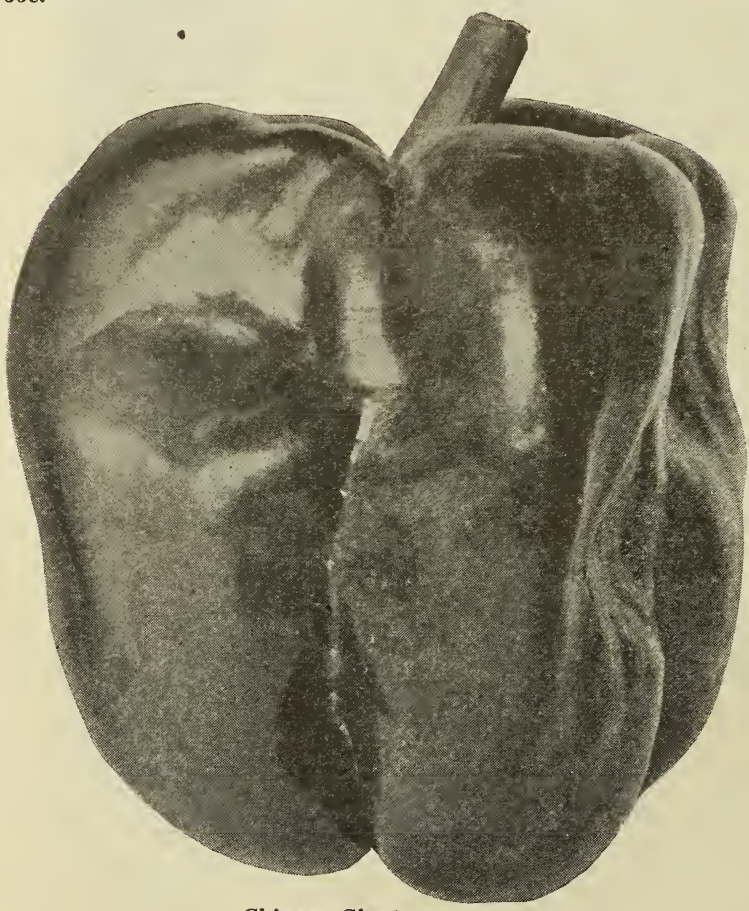

Chinese Giant

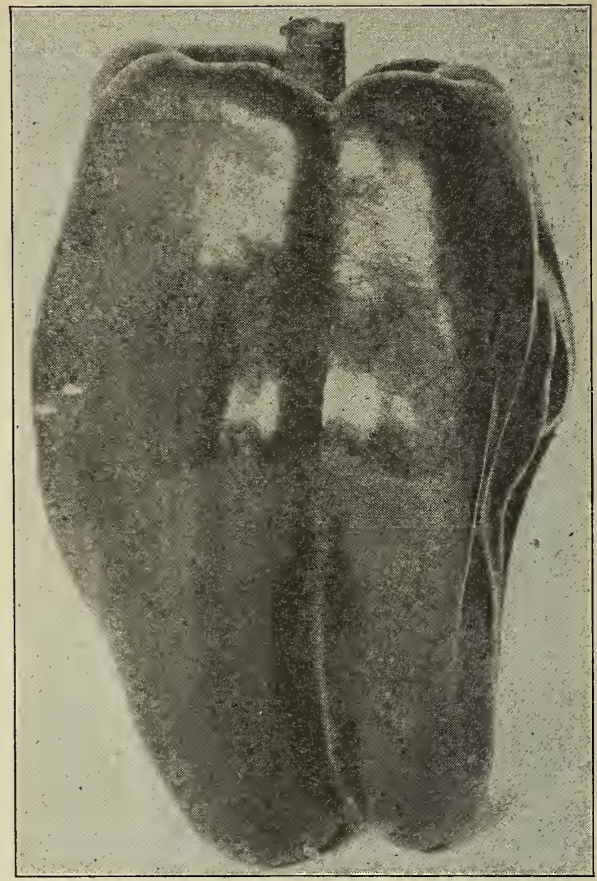

Ruby King

\section{GOLDEN DAWN}

Fruit medium sized, of inverted bell shape, golden yellow color. Flesh thick and mild. Pkt., 5c; oz., 15c; 1/4 lb., 40c.

\section{RED CAYENNE}

A small, long, bright red sort. Very prorictive and extremely strong and pungent. Pkt., 5c; oz., 15c; $1 / 4$ lb., $40 \mathrm{c}$.

\section{RED CHILI}

Pkt., 5c; oz., 15c; 1/4 lb., 40c.

\section{EARLY NEAPOLITAN}

The earliest large pepper. The strong vigorous plants are completely laden with long handsome friuts. The skin and flesh are bright red; they are thick-meated, sweet and mild. For market gardeners and pickling establishments it is of incalculable value. Pkt., 5c; oz., 25c; 1/4 lb., 80c.

\section{PIMENTO}

A new, splendid pepper, already largely used on the Pacific coast, bound soon to become popular everywhere. It is very early and unusually prolific. The fruits are heartshaped, 4 to $41 / 2$ inches long by 3 inches across at the shoulder and are of deep green color when young, turning deep scarlet when matured; they are quite heavy, exceptionally thick green flesh which is very mild and sweet without pungency. The fruits are always handsome, smooth and symmetrical. This variety is much grown by canneries in the West on account of fleshiness, it will prove a good seller in every market and is an excellent pepper for the home garden making a fine dish either green or ripe filled with finely cut meat or other ingredients, and served pickled or baked. Pkt., 5c; oz., $35 \mathrm{c}$; $1 / 4$ lb., $\$ 1.00$. 


\section{CULTURE}

Pumpkins are less sensitive than melons or cucumbers to unfavorable conditions of soil and climate but are cultivated the same, though on a larger scale. They are raised between hills of corn or in fields by themselves, but more properly belong to the farm than the garden as they readily mix with and injure the quality of the finer squash. After danger of frost is over plant th? seed in hills eight to ten feet apart each way, dropping about a dozen seeds in a hill. The soil should be made as rich as possible. If planted with corn twn or three seeds a rod apart each way will be sufficient. When danger from bugs is past, thin to three plants to a hill.

\section{CONNECTICUT FIELD}

A small round variety, popular in extreme northern sections on account of its earliness. Pkt., 5c; oz., 10c; 1/4 Ib., 15c; 1 lb., 50c.

\section{KENTUCKY FIELD}

Grown generally throughout the central section for stock feeding. Fruits very much flattened, creamy yellow color; flesh orange. Very productive. Pkt., 5c; oz., 10c; 1/4 lb., 10c; $1 \mathrm{lb.,} 50 \mathrm{c}$.

\section{LARGE YELLOW FIELD}

Common cornfield pumpkin. Grown largely for stock purposes, suitable also for table use. Oz., $5 \mathrm{c} ; 1 / 4 \mathrm{lb} ., 12 \mathrm{c} ; 1 \mathrm{lb}$., 40c.

\section{GOLDEN OBLONG}

Very hardy and productive; pumpkins fifteen to twenty inches in length and eight to ten inches in diameter. Skin of a rich golden orange, thin but tough making it almost as good a keeper for winter as the hard shell squashes. Flesh is light golden yellow, of very rich fine quality. Pkt., 5c; oz., 10c; 1/4 Ib., 20c; 1 lb., 75c.

\section{LARGE CHEESE}

Best for canning. Has heavy, thick, sweet meat; large, round, flattened variety, with cream-buff skin. An excellent keeper, and very productive. Pkt., 5c; oz., 10c; 1/4 lb., 15c; 1 lb., 50c.

\section{SMALL PIE OR SUGAR}

This is the small, sweet pumpkin that has made the New Englant States famous for their pumpkin pies. It is a very fine grained, most deliciously sweet-flavored sort. Splendid keeper. They average about 10 inches in diameter. Deep orange-yellow color. Pkt., 5c; oz., 10c; $1 / 4$ Ib., 15c; 1 lb., 50c.

\section{IMPROVED CUSHAW}

\section{(See Illustration)}

It is equal to squash, and is used as such. Splendid for baking and making pies. It is large, solid, sweet, verv productive. 'Pkt., 5c; oz., 10c: 1/4 Ib., 20 ; ib., 70c.

\section{WINTER LUXURY}

A splendid pie Pumpkin: shape round, skin finely netted. and beautiful russet-yellow color; flesh thick and of fine flavor. The vines are healthy and produce laree numbers of pumpkins, which keep well Nuring the winter. Pkt., 5c; oz., 10c; 1/4 lb., 20c; Ib., 75 c.

\section{JAPANESE}

Similar in size and form to the well-known Cashaw, but the skin is a dark green, with dark stripes, turning to a rich golden-yellow. Fruits mature early; the large neck is solidly meaty. Flesh deep vellow of fine quality. Pkt., 5c; oz., 10c; 1/4 lb., 20c; Ib., 75 c.

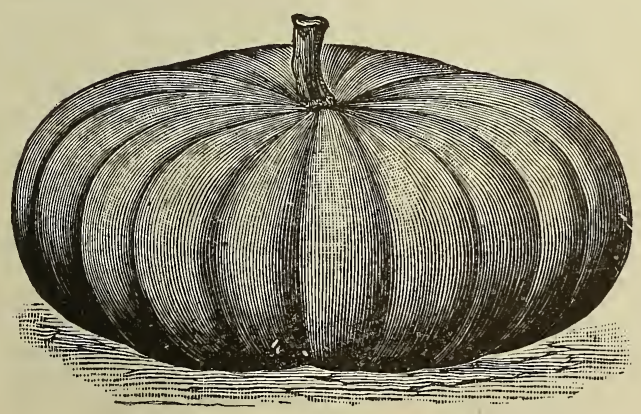

Large Cheese

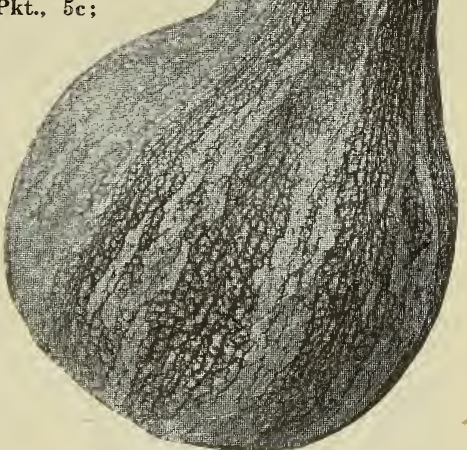

Cushaw Pumpkin

\section{KING OF THE MAMMOTHS}

The largest of all garden pumpkins grown, often weighing 150 to $200 \mathrm{lbs}$. This is an exhibition, of ten kin for fairs. In quality it is the best and it is also a very heavy yielder. The color of the skin is deep cream red, and the meat is deep orange red. Keeps well over winter. Wherever fruits are desired for exhibition plant in hills eight to ten feet apart, giving a liberal quantity of well rotted manure under each hill, when danger from bugs is past leave only the best plant standing and allow only one or two fruits to set on a vine. Pkt., 10c; oz., $15 \mathrm{c} ; 1 / 4 \mathrm{lb} ., 30 \mathrm{c} ; 1 \mathrm{lb}$., $\$ 1.00$.

\section{TENNESSEE SWEET POTATO}

One of the very best for cooking purposes. Nearly pear shaped with neck slightly crooked; skin and flesh creamy white, slightly striped with green. Pkt., 5c; oz., 10c; 1/4 lb., 20c; lb., 60c.

\section{WHITE CUSHAW (Jonathan)}

A popular crook-neck variety with a hard creamywhite shell. Fruits two feet in length, with long solidly meaty neck. Thick flesh of fine quality. Pkt., 5c; oz., 10c; 1/4 lb., 20c; lb., 75c.

S. M. \& P. Rhodes, Ree Heights, S. D., writes : The Sweet Clover we purchaser from you last spring we believe every seed grew twice and did fine. There was some stalks they did not cut the first time that grew to be ten feet high. Now that sounds fishy but it is not for we measured them. We did not measure the roots, but from the way the tops grew the roots must have measured $21 / 2$ feet or more. That is straight goods. The Golden Mammoth Corn did not make good for this was a bad year for corn as it was wet and cold all summer and that being rather late corn for this country did not mature. The garden seeds did fine. The Crimson Clover also did fine; some of it was two feet high and bloomed. I have a nice field of Alfalfa and of Alsike. I think everything that we got grew as well here as it would in the East. We have fine crops
of all small grain, 


\section{RADISH}

\section{Culture}

For forcing sow in hotbed or under glass in rich, sandy soil made perfectly level. Scatter evenly over the surface from fifty to one hundred seeds to the square foot and cover with one-half inch of soil sifted on. Careful watering to keep soil moist, even, moderate temperature and good ventilation are required for rapid and best root development. If the bed is a good one the whole crop can be marketed in twenty-one to forty days after planting.

For open ground culture sow in rich, sandy soil as soon in the spring as it is fit to work, in drills twelve to eighteen inches apart and thin out the plants to prevent crowding. A good dressing of nitrate of soda will greatly stimulate growth and insure tender, brittle roots. Successional sowings from one week to ten days apart will keep up a supply. After the hot weather of summer begins, it is better to sow the summer and winter varieties, as they do not become tough and stringy nor pithy as quickly as the early sorts.

Radishes are subject to root maggots which make them useless for culinary purposes. We know of no certain remedy for this pest. We have found that the best preventive measures are to avoid the use of rank manure and not to sow on ground where radishes, turnips, or cabbages were grown the year previous.

We have been very careful to secure the best seed possible and there is none sold under other names which is better than that of the varieties we offer.

\section{NEW ROSY GEM}

The earliest and most beautiful of the round or turnip-shaped radishes, and a favorite wherever it is grown. Skin bright, scarlet at the top, shading to pure white at the tip, and one of the most tender of all varieties. Pkt., 5c; 1/4 lb., 15c; lb., 55c; postpaid; by express, 5 pounds or over, $40 \mathrm{c}$ per $\mathrm{lb}$.

\section{FRENCH BREAKFAST}

The favorite in Parish markets. A medium-sized radish, olive shaped, small top, of quick growth, very crisp and tender, of a beautiful scarlet color, except near the tip, which is pure white. A splendid variety for the table on account of its excellent quality and its beautiful color. Pkt., 5c; oz., 10c; $1 / 4$ lb., 15c; lb., 50c.

\section{PHILADELPHIA WHITE BOX}

Short top, of rapid growth; perfect turnip shape; extra fine quality, remaining solid and juicy for a long time; is especially suitable for growing under glass in frames. Pkt., 5c; oz., 10c; $1 / 4$ lb., 15c; lb., $50 \mathrm{c}$.

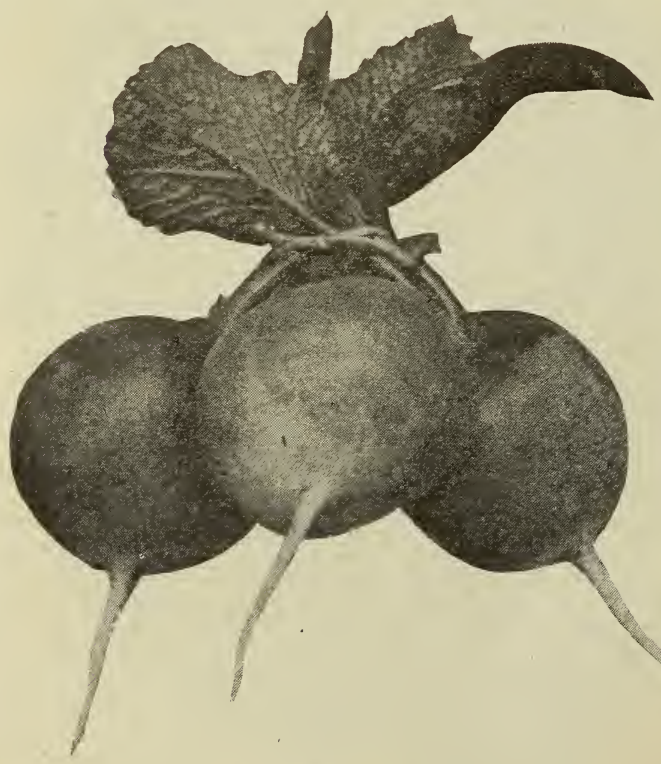

Non Plus Ultra

\section{YELLOW SUMMER TURNIP}

This variety is of quick growth, affording crisp and tender radishes even in a very hot climate and is extensively grown in the south. The roots are uniformly globe-shaped, with skin of golden yellow color. They are but two inches long by two and one-fourth inches in diameter when mature. Pkt. 5c; oz., 10c; $1 / 4$ lb., 15c; 1 lb., 50c.

\section{NON PLUS ULTRA}

This is an excellent extra early forcing radish. The roots are small, nearly round and of bright carlet color. The tops are very small. The flesh is white, erisp and well flavored. One of the handsomest of the forcing varieties. Pkt., 5c; oz., 10c; $1 / 4$ lb., 15c; 1 lb., 60c.

\section{EARLY SCARLET TURNIP}

Very early, small, round radish; entire radish is of a rich scarlet color. This splendid variety has always been a great favorite with market gardeners and for kitchen garden alike. Pkt., 5c; oz., 10c; $1 / 4$ lb., 15c; 1 lb., 50c.

\section{CRIMSON GIANT}

A variety combining earliness and great size. It grows muck. larger than other extra-early varieties, but does not become pithy, even when fully twice as large in diameter and a week older; beautiful crimson-carmine; turnip-shaped; flesh firm, erisp and tender. We recommend it for outdoor garden planting as well as for greenhouse forcing. Pkt., 5c; oz., 10c; 1/4 lb., 15c; 1 lb., 50c.

\section{EARLY SCARLET TURNIP, WHITE TIPPED}

Handsome, bright scarlet, with white tip; most attractive, quality splendid. Similar to Rosy Gem. Desirable for outside growing. Pkt., 5c; oz., 10c; $1 / 4$ lb., 20c; 1 lb., 60c.

\section{EARLY WHITE TURNIP}

This is an early white radish, a little more flat tened than Early Scarlet Turnip, and as offered by us, of smaller size and sometimes a little earlier maturing. While used mostly for early outdoor planting, its very small tops and quick growth make it suitable for forcing. The roots are about one inch in diameter when mature. The flesh is pure white, crisp and tender. Pkt., 5c; oz., 10c; $1 / 4$ lb., 20c; 1 lb., 60c.

\section{EARLY SCARLET GLOBE}

The roots of the variety are slightly olive shaped and are a rich, bright scarlet in color. The flesh is wlite and tender. The roots are fit to pull as early as Non Plus Ultra but are larger when matured. We especially recommend this to gardeners as a large, first early forcing radish. It is also desirable for first early planting outdoors for the home garden and market. Pkt., 5c; oz., 10c; 1/4 lb., 20c; 1 lb., 70c. 


\section{Early Long Radishes}

\section{LONG WHITE VIENNA}

An early, moderately productive, long white radish which is excellent for second early crop, roots are pure white, slender and smooth, average six to seven inches in length and three-fourths inches in diameter at the thickest part. Flesh crisp and tender; tops medium size. Pkt., 5c; oz., 10c; 1/4 lb., $15 \mathrm{c} ; 1 \mathrm{lb} ., 50 \mathrm{c}$.

\section{WHITE SUMMER STRASBURG}

One of the most popular and desirable of all long white radishes for second early or summer crop. Even when comparatively small it is fine quality and remains crisp and tender much longer than other early varieties. Roots when full grown are $1 \frac{1 / 2}{2}$ to 3 inches and five to six inches long, tapering. Tops medium; roots smooth, crystal white color, handsome, showy, crisp and tender, and especially desirable for home or market. Pkt., 5c; oz., 10c; $t / 4$ lb., 15c; 1 lb., 50c

\section{EARLY LONG SCARLET SHORT TOP}

An admirable sort for forcing; also the leading out-door quick-growing variety, both for private and market gardens the country over. Grown in rich, light soil its average length is about 8 inches. Crows half out of the ground, straight, uniform in color, brittle and crisp; small tops. bright scarlet. Pkt., 5c; oz., 8c; 1/4 lb., 15c; lb,. 50c.

\section{WHITE ICICLE}

\section{(See Illustration)}

The finest and longest of the very early pure white varieties. Planted in spring the radishes are ready for use in twenty to twenty-five days their long, slender form and pure paper-white skin are most attractive when bunched for market. This radish is not only tender and crisp when young but retains these qualities until the roots are of large size so that it will remain in good condition for use longer than any early variety. It is excellent for forcing purposes. Pkt., 5.; oz., 10c; 1/4 lb., 20c; lb. 60c.

\section{LONG PEARL FORCING}

Color pearl-white with waxy appearance. Remains two weeks in eat able condition before going to seed. Pkt., 5c; oz., 10c; 1/4 lb., 20c; lb., 60c.

\section{Winter Varieties}

\section{Culture}

Seed for winter radishes should be sown about the first of August in rich, warm, sandy loam, in rows about twenty inches apart. covering half an inch deep. When well up thin to three inches apart in the row and give frequent cultivation. For winter use, the roots should be pulled and packed in damp sand and stored in a cool cellar.

\section{CHINA ROSE WINTER}

This is an extensively grown variety for fall and winter use. It is known also as Chinese Rose. The roots are eylindrical, or largest near the bottom, stump rooted or blunt at both ends. The skin is smooth and of a bright deep rose color. The flesh is white, firm, crisp and pungent. The tops are moderately large with leaves distinctly cut and divided; leaf-stems tinged with rose. The roots are usually four to five inches long by about one and one-half to two inches in diameter when fully mature, sometimes growing considerably thicker. It is a desirable late maturing garden sort. Pkt., 5c; oz., 10c; 1/4 lb., 15c; 1 lb., 50c.

\section{WHITE CHINESE OR CELESTIAL (Winter)}

This is the finest of all extra large white radishes; the roots grow to immense size, averaging from twelve to fifteen inches in length and fully five inches in diameter: the large roots grow mostly above the surface, but are shaded from the sun by the abundant foliage, so that the skin remains a pure paper-white; the flesh is always crisp, mild, and juicy. Pkt., 5c; oz., 10c; $1 / 4$ lb., 15c; $1 \mathrm{lb.,} 50 \mathrm{c}$.

\section{CALIFORNIA MAMMOTH WHITE (Winter)}

Is grown extensively in California; eight to twelve inches long, two to three inches in diameter; white, solid and of good quality. Pkt., 5c; oz., 10c; $1 / 4$ lb., 15c; 1 lb., 50c.

\section{LONG BLACK SPANISH (Winter)}

One of the latest as well as the hardiest; considered excellent for winter use; roots oblong, black, large and firm. It is an excellent keeper. Pkt., $5 \mathrm{c} ; 0 z ., 10 \mathrm{c} ; 1 / 4 \mathrm{lb} ., 20 \mathrm{c} ; 1 \mathrm{lb} ., 60 \mathrm{c}$.

ROUND BLACK SPANISH (Winter)

Roots top shaped, three to four inches in diameter; skin black, flesh white; excellent quality. Similar in characteristics and quality to the long but short but better suited for shallow or heavy soils on account of its shape. Pkt., 5c; oz., 10c; 1/4 lb., 20c; 1 lb.. 60c.

\section{CINCINNATI MARKET}

This superb radish originated in the vicinity of incinnati, Ohio, with the "Glass Gardeners" there, radishes may stand touching each other in the rows. Cincinnati Market Radishes grows perfectly brittle and of delightful flavor. Pkt., 5c; oz., 10c;

\section{IMPROVED CHARTIER}

This radish has rapidly grown in high favor for spring and summer use. It is very handsome, about -third of its length being a rose-color. We find It is very popular among market They retain their good quality for table time. Pkt., 5c; oz., 8c; 1/4 lb., 15c;

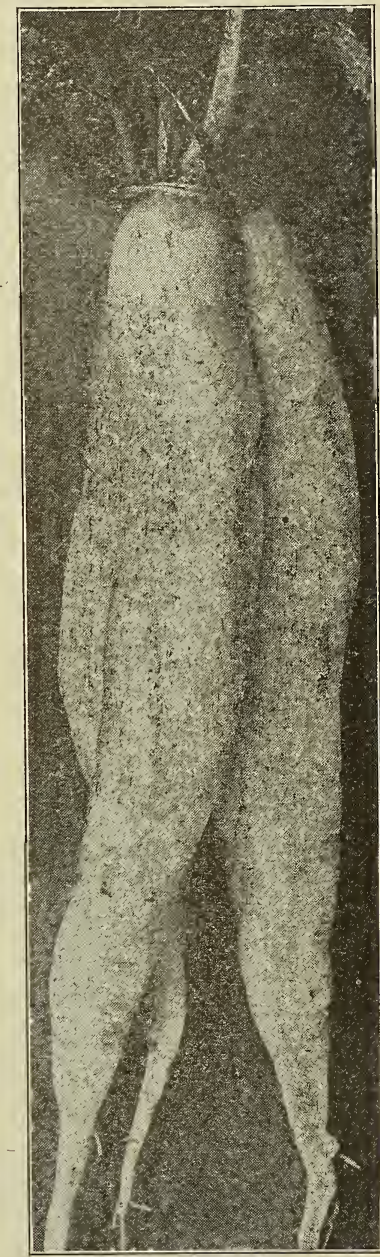

White Icicle 


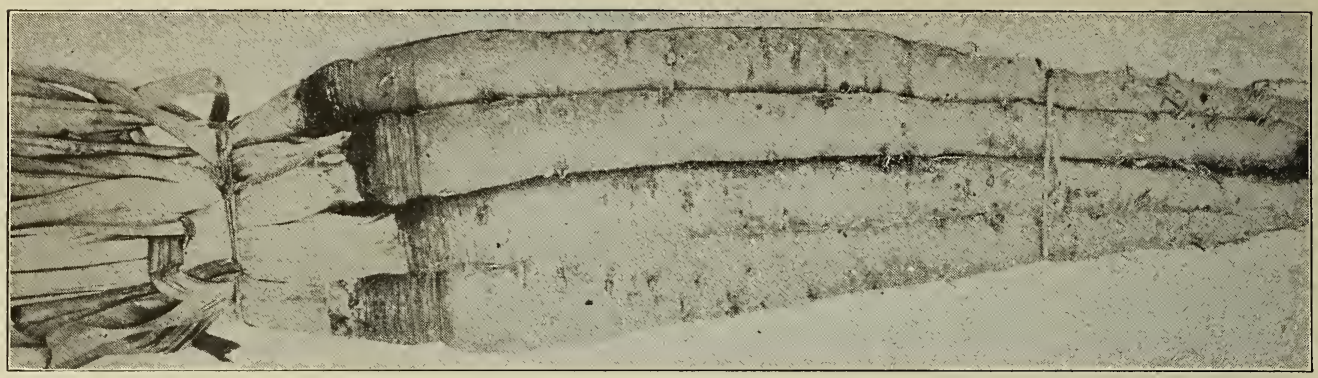

Mammoth Sandwich Island Salsify

\section{SALSIFY \\ Or Vegetable Oyster}

\section{Culture}

This plant is grown largely for winter market, meeting with ready sales, as it is highly esteemed for the fine flavor of the roots when prepared for the table. The roots are served boiled as a vegetable, or may be sliced and fried. Soups made from the roots have a delicious flavor resembling oysters. Seed should be sown early in the spring in shallow drills fifteen inches apart, and when well started should be thinned out to stand four to six inches in the row. Cultivate frequently during growth; keep soil loose and fine. Larger and finer roots can be grown in deep, rich soil. These roots are hardy and can be left in the ground during winter, or the leaves can be cut off in the fall and the roots carefully dug and stored in moist earth for use during the winter months. Use one ounce to one-hundred feet of drill; eight pounds per acre in rows (for field culture) three feet apart.

\section{MAMMOTH SANDWICH ISLAND}

\section{(See Illustration)}

We consider this variety the largest and most profitable salsify in cultivation. Roots three times the size of the ordinary sort, and of more agreeable flavor. It is pure white in color, and has no tendency to split. It is quite free from side roots. Pkt., 5c; oz., 10c; $1 / 4$ lb., 30c; lb., $\$ 1.00$.

\section{SPINACH}

Spinach will succeed finely in any ordinary soil, and its cultivation is a very simple matter. It is grown both as a spring and summer crop. For early use, plant the seed in August or September, in drills 12 to 14 inches apart. At approach of cold weather, cover lightly with straw or any handy litter. Uncover the plants when they begin to make a new growth in the spring. For summer use, sow early in spring. Thin to 3 or 4 inches. One ounce of seed for 50 feet of drill; 12 to 16 pounds for an acre.

\section{NEW ZEALAND}

An especially desirable sort for summer use as it thrives during hot weather in any soil, rich or poor. It has tender shoots of good quality which may be cut throughout the summer. Plant becomes very. large and spreading, leaves small, broad and pointed. Plant three or four seed in hills two feet apart each way. Germination will be hastened by soaking in warm water twenty-four hours before planting. Pkt., 5c; 0z., 10c; 1/4 lb., 20c; 1 lb., 60c.

\section{IMPROVED THICK LEAF}

\section{(See Illustration)}

The market gardener's favorite for fall or spring sowing. A great favorite in all parts of the country, as it furnishes an abundance of heavy, broad, lark leaves of finest quality and appearance. The leaves are attractively curled, and on account of their firmness and substance they remain in prime, salable condition for a long time. Also excellent for home use. Oz., 5c; 1/4 lb., 15c; lb., 40c.

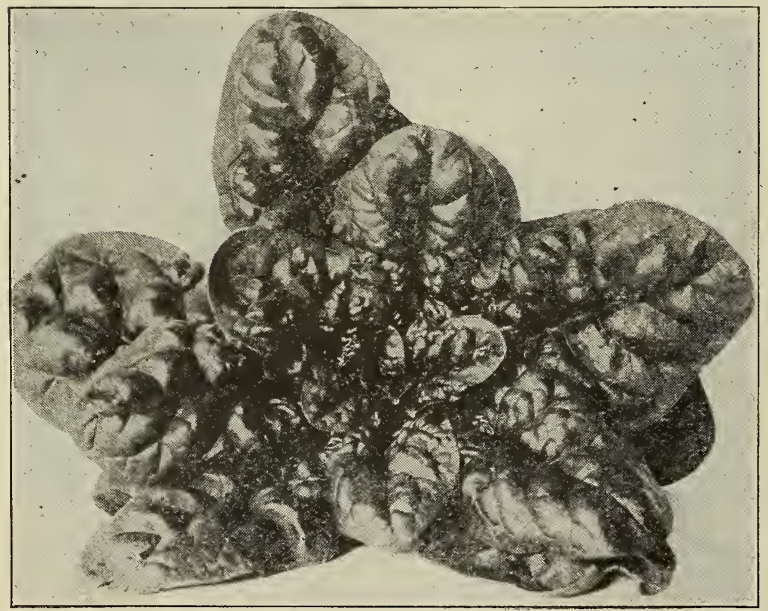

Improved Thick Leaf

\section{CURLED BLOOMSDALE}

Large, curled and wrinkled; leaves tender and of fine flavor. Pkt., 5c; oz., 10c; $1 / 4$ lb. 15c; lb., 40c; by express, 5 lb. or over, per lb., 20c.

\section{LONG STANDING}

The best for spring sowing, leaves large and thick, stands long before going to seed. Pkt., 5c; oz., 10c; 1/4 lb., 15c; lb., 25c; by express, 5 pounds or over, $12 \mathrm{c}$ per lb.

\section{PRICKLY SEEDED}

Vigorous and hardy and recommended for fall sowing. Pkt., 5c; oz., 10c; 1/4 lb., 15c; lb., 25c; by express, 5 pounds or over, 12c per lb.

\section{VICTORIA}

Were we asked to name the "best allaround" variety of spinach, we would unhesitatingly say "Victoria." It is an excellent sort, whether grown for home use or market, and it never fails to please the most critical. Oz., 5c; $1 / 4$ lb., 15c; 1 lb., 40c; by express, 5 lb. or more, $22 c$ per lb. 


\section{SQUASH}

The squash is one of the most nutritious and valuable of our garden vegetables. The summer varieties come to the table early in the season, while the winter sorts can be had in perfection from August until the summer sorts are again in condition. Plants are tender and sensitive to cold, and planting must be delayed until settled warm weather. Summer varieties should be planted four to six feet apart each way, and the winter sorts eight to ten. Three plants are sufficient for a hill.

\section{YELLOW BUSH}

Scalloped. Similar to the White Bush Scalloped, except in color. Pkt., 5c; oz., 10c; 1/4 F., 20c; lb., 70c.

\section{WHITE BUSH SCALLOPED \\ (See Illustration)}

An early summer variety. Pkt., 5c; oz., 10c; 1/4 lb., 26c; lb., 70c.

\section{GIANT SUMMER CROOKNECK}

A new, valuable and distinct variety, the result of years of careful breeding and selection, and it is now one of the most fixed and distinct of our summer squash. We recommend this sort as the most beautiful and one of the very best of the summer varieties. Pkt., 5c; oz., 10c; 1/4 lb., 20c ; lb., $75 \mathrm{c}$.

\section{BOSTON MARROW}

An excellent variety for fall and winter use. Pkt., 5c; oz., $10 ; 1 / 4$ lb., 20c; lb. 75c.

\section{NEW FAXON}

A variety and distinct from other squashes. When ripe some are pale yellow with yellow stripes in hollows, others are mottled with green and striped lighter. It can be used as a summer squash for it matures early. It is also a good winter variety of excellent keeping quality. It is ripe or green. The flesh is of deep orange yellow; before cooking seems to have a shell similar to any other squash, but when cooked there appears to be no shell. Pkt., 5c; oz., 10c; $1 / 4$ lb., 20c; lb., 70c.

\section{FORDHOOK}

Fine grain, meaty and of fine flavor. Can be used at any time of their growth. Pkt., 5c; oz., $10 \mathrm{c}$; $1 / 4$ lb., 25c; lb., $75 \mathrm{c}$.

\section{WARTED HUBBARD}

A Hubbard Squash with warted skin. The vines grow strong and produce a large number of Squashes, which are of good size and keep well. Pkt., 5c; oz., 10c; 1/4 lb., 25c; lb., 80c.

\section{IMPROVED MARBLEHEAD}

Resembles the Hubbard but is earlier; has a gray, hard, shell; popular winter sort. Pkt., 5c; oz., 10c; $1 / 4$ lb., 25c; lb., 80c.

\section{PIKE'S PEAK or SIBLEY}

A very productive variety, maturing at the same time as Hubbard; flesh solid and of a rich goldenorange color. Pkt., 5c; oz., 10c; 1/4 lb., 2uc; lb., $70 \mathrm{c}$.

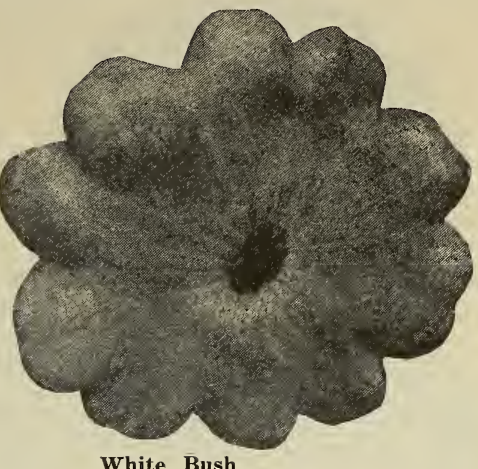

LGSEX HYBRED or HARD-SHELLED TURBAN

Standard winter sort; flesh a trifle darker than Hubbard; excellent keeper. Pkt., 5c; oz., 10c; 1/4 lb., 25c; lb., 80c.

\section{MAMMOTH CHILI}

The largest of all Squash; grows to an enormous size. One of the most profitable sorts for stock feeding. Keeps well throughout the winter. This variety is also extensively grown for fair exhibits and because of its size and weight attracts much attention. Pkt., 5c; 0z., 10c; 1/4 lb., 30c; lb., \$1.00. DELICIOUS

A squash of the richest and finest quality known. It is of medium size, dark green in color and with very thick flesh which cooks dry, and is of superior flavor. Although a good fall variety it is in its best condition in the winter. Pkt., 5c; oz., 10c; 1/4 lb., 35c; 1 lb., $\$ 1.00$.

\section{MAMMOTH WHITE BUSH SCALLOPED}

of all round scallop or patty pan squashes; this is the very best; not quite as early as Early White Bush, but far superior in size and quality. Sometimes known as vegetable marrow. Fruits round, white deeply scalloped, lobes being in pairs; very tender and delicious. Pkt., 5c; oz., 10c; 1/4 lb., 20c; 1 lb., 70c.

MAMMOTH YELLOW BUSH SCALLOPED

Decidedly the best strain of Yellow Scalloped Summer Squash. Double the size of the old sort, retaining all its good points. Pkt., 5c; 0z., 10c; 1/4 lb. 20c: 1 lb, 70c.

\section{BOSTON MARROW}

A moderately early, decidedly prolific variety, ten to fourteen inches diameter, twelve to sixteen inches long, light salmon color, very thick meated, fine grained, sweet, excellent quality every way and a reasonably good keeper. Pkt., 5c; oz., 10c; 1/4 lb., 20c; 1 lb., 75 c.

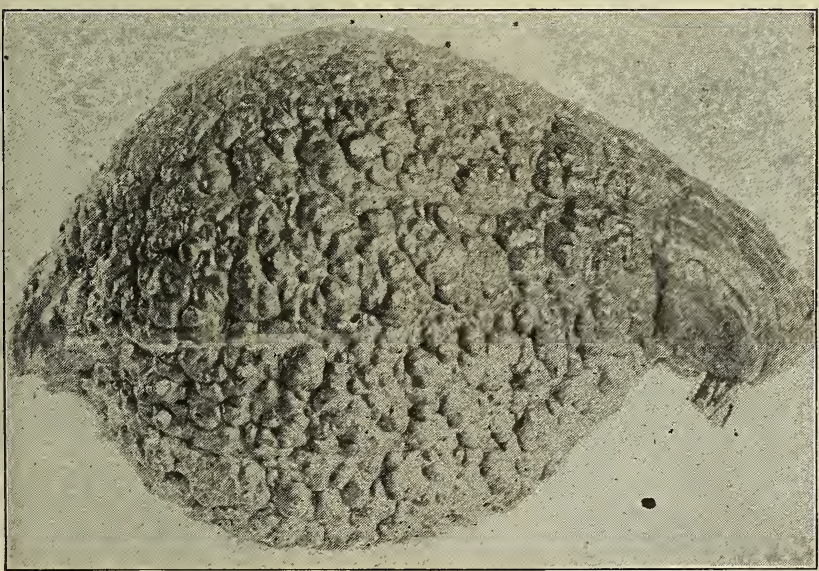

Hubbard Squash

\section{HUBBARD}

This is a superior variety and one of the best of winter squashes. Flesh, bright orange yellow, fine grained, very dry, sweet and rich flavored. Keeps perfectly good throughout the winter. We have taken the utmost pains with this sort, and can recommend our stock as in all probability the best in the country, and think our customers can plant it in perfect confidence that every fruit will be a pure Hubbard. Pkt., 5c; oz., 10c; $1 / 4$ lb., 25c; lb., $75 \mathrm{c}$.

\section{GOLDEN HUBBARD}

This squash is a great improvement on the old Hubbard, which it resembles in shape, but is of larger size. It is much more attractive on account of the color, which is a bright orange. The flesh is golden yellow, fine grained, of the best flavor and cooks dry. Its color and productiveness, in addition to its fine quality and large size place it in the front rank as a market gardeners' sort as well as for the family garden. A good keeper. Pkt., 5c; 0z., 10c; 1/4 lb., 25c; lb., 75c. 


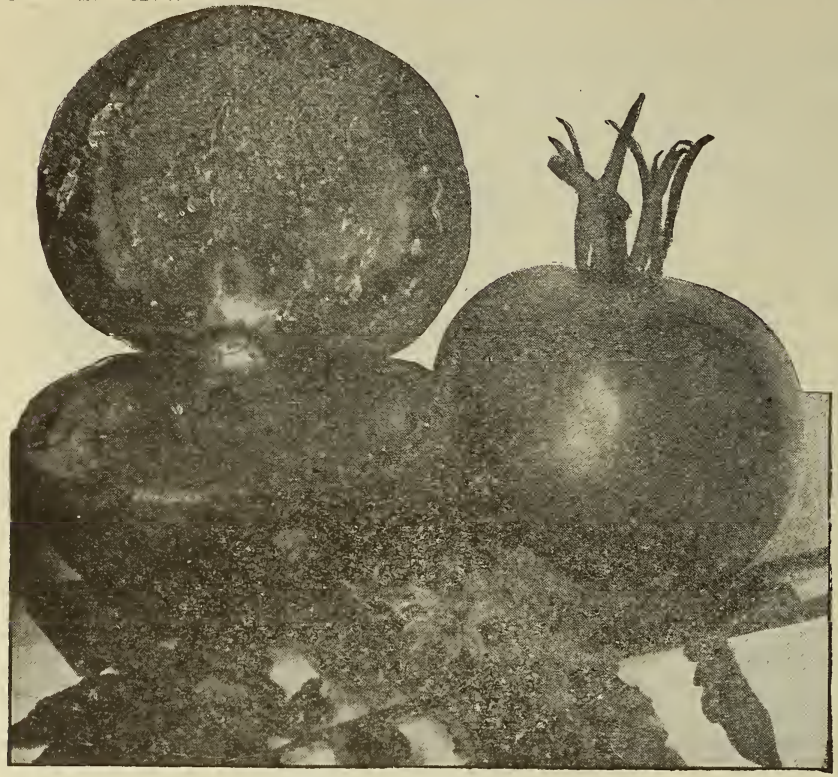

\section{Bright Red Varieties}

\section{SPARKS' EARLIANÁ}

The most important novelty in tomatoes. The largest extra early tomatoe ever introduced. This famous new variety was originated by Mr. George C. Sparks, of Salem Co., New Jersey, where the greatest competition exists among growers to be the first in the market. The plants are quite hardy, with rather slender, open branches and moderate growth, well set with friut, nearly all of which ripen extremely early in the season. The fruits are deep scarlet and grow closely in clusters of five to eight, all of medium size, averaging $2 \frac{1}{2}$ inches in diameter. They are smooth and solid, quite thick through and free from rough ribs or eracks. The flesh is deep red, with solid center and small cells, slightly acid flavor. The seed that we offer of this variety is of our growing, from selected stock of Mr. Sparks' extreme early free fruiting strain. Pkt., 5c; oz., 25c; 1/4 lb., 75c; lb., $\$ 2.50$.

\section{Davis' Quality Tomatoes}

All our tomato seeds are grown from stalks raised strictly for seed purposes, and from seed stalks carefully selected and saved by ourselves. We challenge comparison of our stock with any offered by any other firm.

\section{LIVINGSTON'S HUMMER}

A new distinct early variety having several very important points of advantage of most varieties. It is perfectly round and very smooth having no stem end indentation whatever, eliminating greatly the loss from preparing the fruit for use. Cracked tomatoes are very uncommon and it grows in large clusters of mediumsized fruit of very even size. Being of even size makes it very desirable for canners and home use. The color is a very attractive, bright scarlet. The fiesh is a rich crimson scarlet and of ihe very best flavor. Pkt., 5c; oz., 30c; $1 / 4$ lb., $\$ 1.00$.

\section{LIVINGSTON'S DWARF STONE}

This is the largest dwarf tomato in existence. In habit of vine it resembles the Dwarf Champion, but of stronger srowth and is more erect. The fruit is similar to the Tall Stone in color, shape and size. Specimens weighing one pound each are quite common. The season is fully as early as the Dwarf champion, but the fruits are double the size. Pkt., 5c; oz., 25c; 1/4 lb., 75c.

CHALKS" EARLY JEWEL

The largest and smoothest of the extra early red varieties. A week or ten days later than Sparks' Earliana; the fruits are larger and smoother. The vines grow very compactly, are very productive, and bear continuously. Pkt., 5c; oz., 20c; 1/4 lb., $75 \mathrm{c}$.

\section{LIVINGSTON'S CORELESS}

The most distinct variety yet introduced, being free from the very objectionable depression in the stem. This feature alone should bring this variety to the front rank among canners, market gardeners and those desiring good tomatoes for home use. The color is bright red, a very important feature to canners, although objectionable to market gardeners in some localities. The fruit is very solid, having very small seed cells surrounded by a solid meaty flesh of bright red color and of a very delicious flavor. As a tomato to be shipped or hauled a long distance this variety is hard to excel, as the firm outside and inner walls of flesh make it less liable to be damaged. Pkt., 10c; oz., 30c; 1/4 lb., $\$ 1.00$.

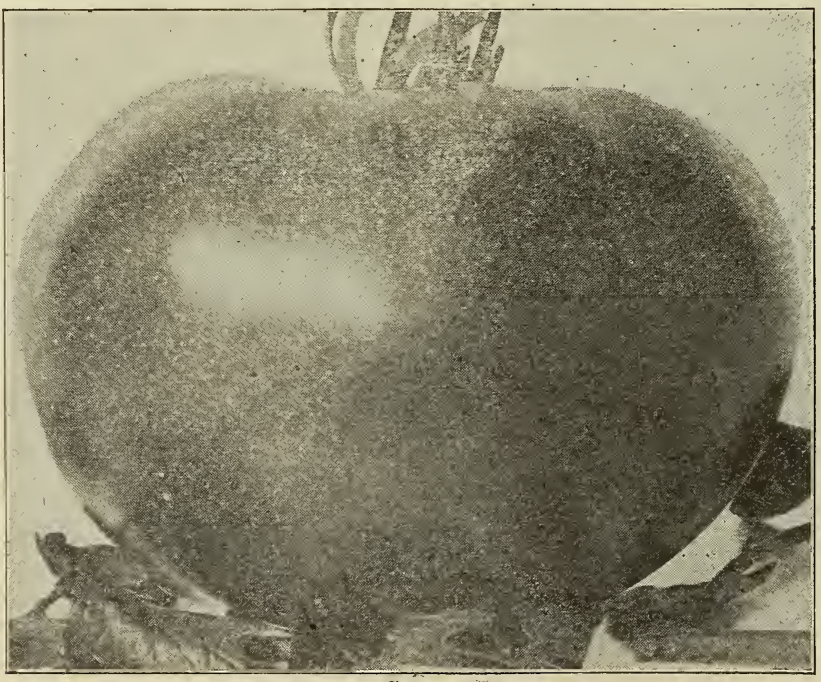

\section{STONE}

One of the largest and most solid main crop or late, bright red varieties. It is unsurpassed for slicing and canning. The vines are large, vigorous, and very productive. The fruits are bright deep scarlet, nearly round or slightly flattened, exceptionally smooth and uniform in size. Our stock is distinctly superior to most of that offered under this name, being larger, smoother, more uniform and better colored. Pkt., 5c; oz., 20c; $1 / 4$ lb., 60c; 1 lb., $\$ 1.75$.

\section{BONNY BEST}

A favorite tomatoe of medium size. They are of bright scarlet color, always smooth and of remarkable uniform size and shape. An elegant sort for market and shipping on account of its even size. Well adapted for forcing under glass. Pkt., 5c; oz., 25c; 1/4 lb., 75c.

\section{FAVORITE}

One of the largest and most perfectly formed early tomatoes grown Fruit deep red, very solid and has few seeds and bears shipping long distances Pkt., 5c; oz., 20c; 1/4 lb., 60c; 1 lb. $\$ 1.75$. 


\section{TOIMATOES-Contínued}

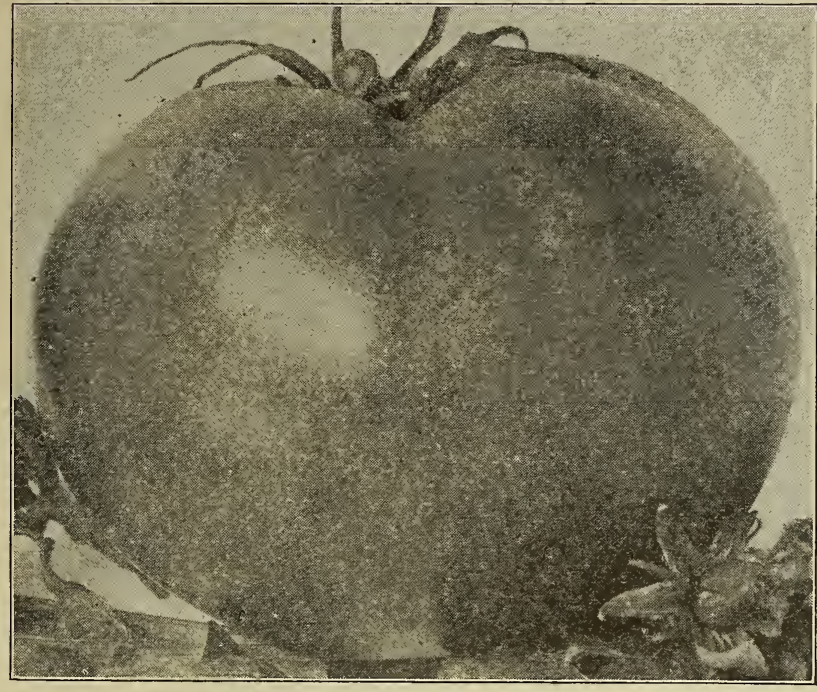

June Pink

\section{MAGNUS}

This grand new variety has been spoken of only in the highest terms by those who have tried it. The fruit is very large, solid and with few seeds. Its color is a very glossy crimson, tinged with purple. In shape it is perfectly smooth and thicker from stem to blossom end than most varieties, making it very handsome and salable. It is a robust grower, with short joints, setting the fruit clusters closer than most sorts, and is therefore a greater yielder. The fruit is borne in clusters of from 6 to 10 and it is not uncommon to find clusters with four or five ripe ones ready for the first picking. It is one of the best varieties for forcing under glass, as it can be set closer and bears large clusters of as large tomatoes as can be grown in the open field. Pkt, $5 c ; 0 z ., 20 c ; 1 / 41 b \cdot, 50 c$.

\section{BUCKEYE STATE}

The largest smooth tomato in the world. This new tomato is one of the largest of the new sorts. It is a very heavy cropper, the tomatoes being borne in clusters of from 4 to 8 . The color is a glossy crimson, with a purple tinge. It is very solid, meaty and of luscious quality. Pkt., 5c; 0z., 20c; $1 / 4$ lb., 60c.

\section{PONDEROSA}

No other tomato approaches this for size, weight and solidity. The vines are strong and vigorous. Fruit large, solid and of good flavor; specimens have been grown to weigh four pounds; bright red; very few seeds. Pkt., 5c; oz•, 25c; 1/4 lb., 75c; lb., \$2.75.

\section{DWARF CHAMPION}

Distinct in foliage and habit of growth, being conspact and upright; fruit smooth, early and purplish red. Pkt., 5c; oz., 25c; $1 / 4$ lb., 75c.

\section{ACME}

Very early and productive; fruit medium sized, and of a dark, rich red, slightly tinged with purple; very solid and smooth. Pkt., 5c; oz., 20c; 1/4 lb. $60 \mathrm{c}$.

\section{DWARF GIANT}

This new tomato we have tried out thoroughly and must say that it is the finest dwarf tomato ever introduced. The fruits are large, smooth and of finest quality. It is uniform in growth, foliage dark and produces an enormous crop of extremely solid, fine flavored fruit. It is well named (Dwarf Ponderosa) for it is even better than Ponderosa for it is

\section{Purple Sorts}

\section{JUNE PINK TOMATO}

(See Illustration)

Many persons prefer the pink tomato, and to these this new variety will appeal. It really is a Pink Sparks' Earliana, being identical in growth and shape, ripens fully as early and is of a good quality. The fruit measures about three inches in diameter and is quite deep. This variety is not only the earliest but continues to ripen its fruit all summer long, until frost strikes the vines. Pkt., 5c; oz., 30c; $1 / 4$ lb., $\$ 1.00$.

NEW GLOBE

(See Illustration)

The fruit of the new variety is globe-shaped, giving them a much handsomer appearance than the flat varieties, also permitting more slices per fruit when preparing for table use. The tomato has a most desirable, fine, glossy rose color, tinged 'with purple. The fruits are large, very smooth, having few seeds and firm flesh. It is an extremely productive variety and a remarkable keeper of recent years. Pkt., 5c; oz., 30c; 1/4 lb., $\$ 1.00$. 


\section{TURNIPS}

\section{Culture}

The value of Turnips and Ruta Bagas for feeding stock in fall and winter is not fully appreciated, as they are much liked by all kinds of stock and serve to keep them in good condition. They should not be fed, however, in large quantities to milch cows, or the flavor of the milk will be disagreeably affected. We earnestly recommend that farmers increase their sowings largely, for we are sure the crop will prove remunerative for stock feeding as well as for table use when the roots are comparatively small.

Both of these wholesome vegetables are very easily affected in their form and flavor by soil, climate, and mode of culture. The turnip plant is distinguished from the ruta baga by its rougher leaves; the root usually matures earlier and is smoother and more symmetrical. There are a great many varieties, but our list comprises

the best for the garden and farm.
For early use sow the small sort as soon as the ground can be worked in the spring, in drills fourteen inches apart, the ruta baga thirty inches. As the seed is very fine, it should be covered but slightly. Select light, if possible, new soil, and manure with ashes or phosphates. Should the young plants be troubled with insects, a sprinkle of plaster will be found beneficial., Of the early varieties, thin the plants to six inches apart, and the ruta bagas to one foot. For fall and winter the early kinds should be sown from middle of July to the middle of June to the first of July, using one and a half pounds to the acre.

For winter keeping, store the turnips in a cool cellar and cover with sand or turf to keep them fresh. Another method is to put them in a pit dug in dry soil where there will be no danger of water standing and to cover with straw overlaid with earth sufficiently deep to keep out frost. When they are thus protected, turnips will keep well till spring

\section{EARLY PURPLE TOP STRAP-LEAVED}

\section{(See Illustration)}

This is highly recommended for garden use. The top is purple, while the bottom is white. Quality fine. Pkt., 5c; oz., 10c; 1/4 lb., 15c; lb., 50c; by express, $5 \mathrm{lb}$. or over, $35 \mathrm{c}$ per $\mathbf{l b}$.

\section{WHITE MILAN}

For early use the white top turnips are better than the purple. In our experimental grounds this white variety matured earlier than the Purple Milan, which make sit the earliest of all turnips. Top and tap root small. Certainly the king of the extra early turnips. The beauty of its clear, white color and the fine symmetry of its shape make this a very attractive variety. It takes well in the market. Pkt., 5c; oz., 10c; 1/4 lb., 15c; lb., 50c; by express 5 lb. or over, $35 \mathrm{c}$ per lb.

\section{PURPLE TOP WHITE GLOBE}

A variety of decided merit. Globular shape, very handsome and of superior quality, either for the table or stock. It is a heavy producer, early, of rapid growth, and an excellent keeper. Pkt.; 5c; oz., 10c; $1 / 4$ lb., 15c; lb., 60c; by express, $5 \mathrm{lb}$. or over, 35c per $\mathrm{lb}$.

\section{PURPLE TOP YELLOW ABERDEEN}

Roots medium sized, round. Flesh pale yellow, tender and sugary. Hardy and productive, and keeps well. It is an old esteemed variety, approaching very nearly the Ruta Baga in hardiness and firmness of texture. Pkt., 5c; oz., 10c; 1/4 lb., 15c; lb., 50c.

\section{WHITE EGG}

A rapid growing, egg-shaped variety, with thin, white skin. It has fine grain. Flesh of mild sweet flavor. Pkt., 5c; oz., 10c; 1/4 lb., 20c; lb., 60c. SCARLET KASHMYRE

The beautiful pinkish-red color of this new turnip makes it very striking. It is unique among turnips, bearing some resemblance to a large radish. It produces large, smooth, white-fleshed roots of excellent keeping qualities. Among the earliest. Pkt., 5c; oz', $10 \mathrm{c} ; 1 / 4$ lb., 25c; lb., 75c.

COW HORN OR LONG WHITE

This variety is pure white, except a little shade of green at the top and is carrot-like in form, growing nearly half out of the ground and slightly crooked. It is delicate and well flavored, of very rapid growth, and has obtained considerable favor as a market sort for fall and early winter use. Pkt., 5c; oz., 10c; $1 / 4.1 b, 15 c ; 1 b ., 50 c$.

\section{RUTA-BAGAS}

(Swedish or Russian Turnips) IMPROVED AMERICAN (Purple-Top)

Very hardy and productive; flesh yellow, sweet and solid; good for stock or table use. Pkt., 5c; oz., 10c; $1 / 4$ lb., $20 \mathrm{c}$.

\section{WHITE RUSSIAN or LARGE WHITE}

Grows very large; excellent for table or stock; flesh is firm, white and solid; the best keeper of any white variety. Pkt., 5c; oz., 10c; $1 / 4 \mathrm{lb}, 20 \mathrm{c}$.

\section{TOBACCO}

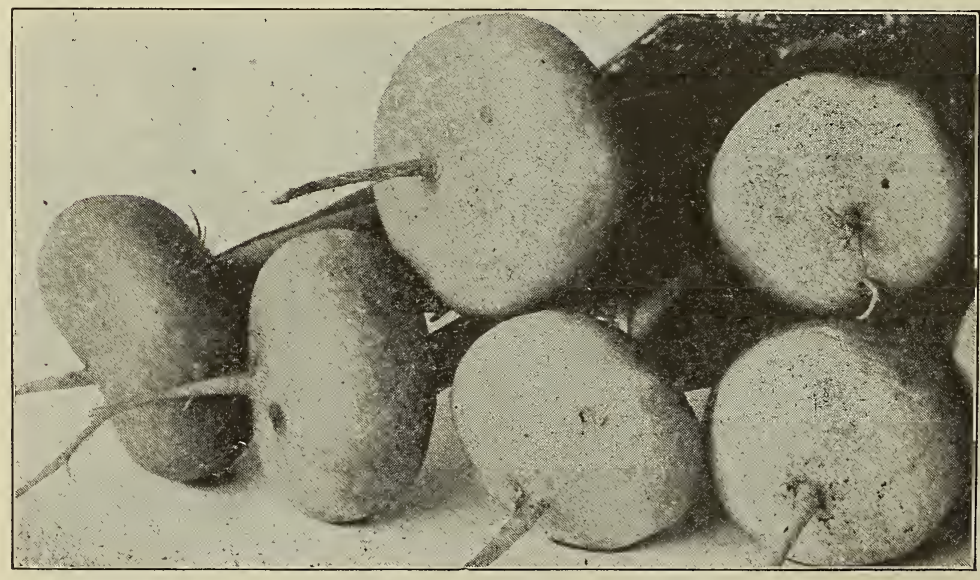

Connecticut Seed Leaf

An old well known variety. Pkt., 5c; oz., 25c; $1 / 4$ lb., $75 \mathrm{c}$.

HAVANA IMPORTED

A heavy cropper of fine texture, delightful flavor and the earliest cigar variety to mature and ripen. Pkt., 5c; oz., 30c.

\section{WHITE BURLEY}

A standard sort which is more largely grown in Blue Prass region of Kentucky, Ohio, Tennessee and Missouri than any other sort. It is a large growing sort having very broad leaves of finest quality and largely used for fine bright leaf, especially for cigarette tobacco, fine bright mixing tobacco and outside wrappers for plug. Commands highest prices on the market and where soil is suitable the most profitable of all sorts. Pkt., 10c; oz., 30c; $1 / 4$ lb., $\$ 1.00$; lb., $\$ 2.50$. 


\section{SEED CORN}

Do you deem it wise to plant doubtful seed Corn when good seed is cheap? It costs less than thirty-five cents per acre to use our carefully selected Seed Corn. We wish we could make you understand how we handle our Seed Corn business and how much pains we take to try and get the best seed that can be produced. We, select the corn in the field and save only what looks like a first class seed ear and when we get the corn to our Dry-Houses, we look over every ear before we put it in the drying racks where it is dried out before cold weather sets in, and keeps in perfect condition until we need it.

The Corn is then taken to the work-room where it is carefully sorted, butted and tipped.

We shell our corn on a common two-hole sheller, run at a low speed, so as not to crack any grains, and after it is shelled it is put through our new seed grader, which has four sorting screens and strong even blast of wind that takes out all but perfect grains.

\section{EAR CORN}

The Corn is the same, whatever way you get it. We are not ashamed of our Corn and will not make any extra charge for ear corn as some firms do. We ship ear corn in seamless bags without extra charge for bags. The tendency for the last few years is to turning out the best grade of seed already prepared for the planter.

\section{OUR GUARANTEE}

Any Seed Corn we ship you if it fails to look like you think it should, ship it back and we will refund every cent you paid. We sell it subject to your own test and approval. We will supply you with Corn that you will be proud to show to your neighbors; either the seed or the crop. We will sell you Corn either on ear or shelled and if you desire every ear tested we will do that for you. We will take six grains out of each ear and will not ship you an ear that does not send up six strong sprouts for $\$ 5.00$ per bushel.

\section{LARGE LOTS}

The prices in this catalogue on seed Corn apply to lots ap to ten bushel. On large lots we can sometimes make special prices and would be pleased to have you write us about it.

\section{GRADING}

The grains of all Corns excepting Ensilage and Fodder Corn are graded and hand-picked. Absolutely no butt or tip or uneven grains in our seed.

\section{GUARANTEE OF SEED CORN}

We can't guarantee you a crop because we can't be there to plant it and tend it; but you can take the seed home and examine it and test it and if you find that you have been beat on the deal you can send it back to us and we will refund you back the money. All we ask is a square deal. We do not and cannot guarantee the stand or the crop; when you begin to plant our guarantee ends.

\section{YOUR CHECK IS GOOD}

We like to get personal checks-if you have the money to back them. A check is as good as a draft and saves you a trip to town. We like to sell to folks who have a Bank Account.

Shelled Corn.-Single ear tested. $\$ 1.50$ per pk.; $\$ 5.00$ per bu.

Ear Corn will be boxed and shelled Corn double sacked.

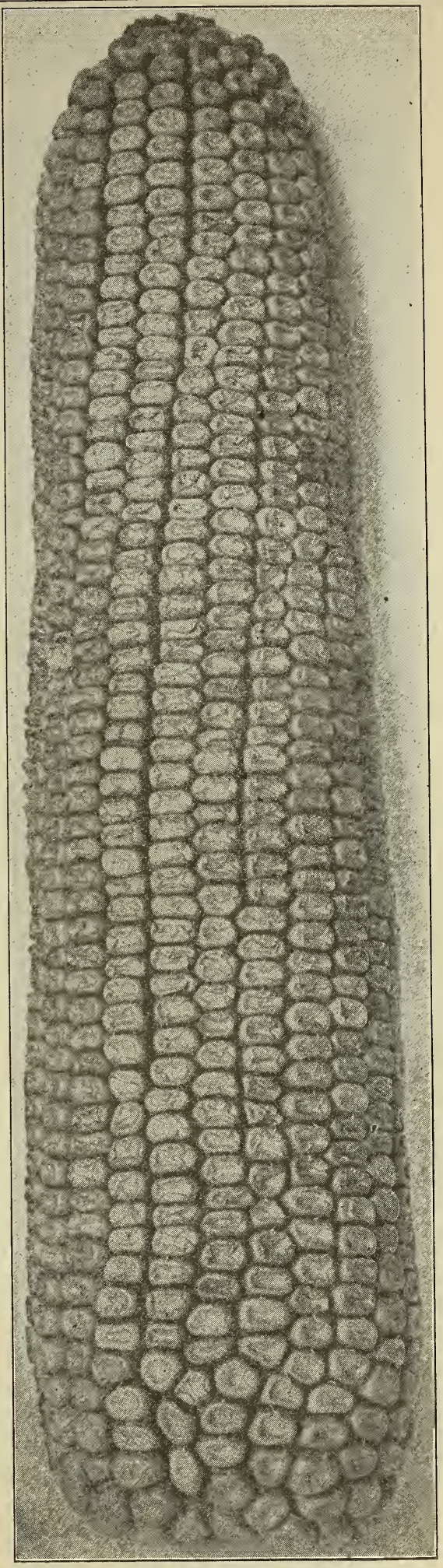

Reid's Yellow Dent 


\section{CORN}

\section{Davis' Improved Yellow Charge}

\section{The Largest, Handsomest and Miost Productive 100 Day Corn Ever Produced}

We have sold this corn for the past fifteen years and all who have grown it are more than pleased with it. Through the country it has made large yields of both corn and fodder. It grows to be a perfect field corn as to size of ear, color, size of cob, length of grain, size and extra quality of fodder. It will produce more corn and fodder than the Leaming or other large varieties requiring, a much longer time to ripen. The grain is a bright yellow. The $\mathrm{cob}^{\circ}$ is very small considering the size of the ear.

We wish to call the attention of our customers to the following few points which we claim for Improved Yellow Clarage.

1st. It is the best feeding corn in existence.

2nd. It is naturally a great yielder.

3rd. It will mature in about 100 daýs.

4 th. It is an excellent, all round variety of corn for all general purposes.

5th. The fodder grows strong, rank and quick, nine to twelve feet high, and stands storms to a remarkable degree.

6th. It will yield as much as any other kind of corn.

7th. It stands drought better than any other kind of corn.

8th. It is the best corn in cultivation to grow on any kind of soil.

9th. It will make friends. where others fail.

10th. The farmer can make more money growing this variety and selling it to his neighbors for seed than any other crop he can grow.

Summing it all up, it is the acme of perfection, unsurpassable. Don't fail to give it a trial. Get neighbors to order with you. Pkt., $80 \mathrm{c}$; 1 bu., $\$ 3.00$; bag of $21 / 2$ bu., $\$ 7.00 ; 10$ bu., or more, $\$ 2.75$ per bu.

\section{Pride of the North.}

This variety has been grown and improved in the northern part of Ohio. The ears are 8 to 10 inches long, with small cob and long kernel. Seventy pounds of ears will make sixty pounds of shelled corn. Color, bright orange and very uniform. Will ripen in ninety days, and will mature in this latitude when planted the middle of June. Pk., $80 \mathrm{c}$; bu., $\$ 3.00$; bag of $21 / 2$ bu., $\$ 6.50 ; 10$ bu. or more, $\$ 2.50$.

\section{Virginia White Cob Ensilage.}

This is one of the best fodder corns, either to feed green right from the field or to put in the silo. It is sweet, tender and juicy, has short joints, abundance of leaves and grows to a great height. It is adapted to every section of the country. Pk., 60c; bu., $\$ 2.50$; bag of $21 / 2$ bu., $\$ 6.25$; $10 \mathrm{bu}$. or more, $\$ 2.40$ per bu.

\section{True Leaming.}

An extensively grown large yellow dent variety. Has pure, glossy yellow ears, growing low on a strong, heavy stock. The grains are square, long and ripen quite early. The seed we offer is True Leaming. Pk., 80c; bu., \$3.00; bag of $21 / 2$ bu., $\$ 6.50 ; 10$ bu. or more, $\$ 2.50$ per bu. 


\section{CORN-Continued}

\section{Davis' 110-Day Yellow}

\author{
An Ideal Feeders Corn of Light Golden Color
}

(See Illustration)

This variety has been bred for the past 15 years by a nıan who raises a large amount of corn for his own feeding and was bred for large yield and good feeding qualities combined and we think it comes as near being an Ideal Corn as any we have ever seen. Planted side by side with Reid's Yellow Dent and Leaming it has out-yielded both varieties and is better adapted to this climate than Reid's. Yellow Dent. The fodder is medium size and sets the ears from 3 to 4 feet from the ground. It roots very deep and stands storms better than most corns. With us it does not yield as much as Davis' Golden Mammoth and the ears are not as large but has deeper grains and smaller cobs. The corn is rougher than Davis' Golden Mammoth; the butt and tip are well filled and the cob is of medium size of a dark red color and is very hard. Most of our customers that grew this corn the past year claim that it dried out the best of any corn in their neighborhood. Pk., $\$ 1.00$; bu., $\$ 3.00$; bag of $21 / 2$ bu., $\$ 6.50$.

\section{DAVIS' GOLDEN MAMMOTH}

This is the largest corn that is sure to mature in from 100 to 120 days. The winners of the contest in Delaware County for the past four years have won their trips to Washington with this corn and it has made large yield throughout the country. The ears are large, of a deep yellow color, the grain is fairly deep and the cob is of medium size considering the size of the ear. It will stand a prolonged drought better than any varieties that we know of. This corn is a strong grower and many of our customers are growing over $100 \mathrm{bu}$. per acre nearly every year on good land. We get a great many testimonials praising this corn on account of its yielding qualities, although it is not the show corn that Reid's Yellow Dent is. Pk., 80c; 1 bu., $\$ 3.00$; bag of $21 / 2$ bu., $\$ 6.50$; 10 bu. or more, $\$ 2.50$.

\section{BOONE COUNTRY WHITE}

This is the best type of White Dent Corn for the Central Corn Belts. At the Springfield Fair this corn is always a winner in the White classes. The Corn has been bred for very large ears and consequently matures rather slowlyabout one hundred and twenty days of good weather. Tips do not fill as good as some varieties. However, our strain has been selected to improve this fault, as can be readily determined by the ears in our crates. The ear tapers slowly, length usually 10 inches, circumference $7 \frac{1}{2}$ inches; 16 to 22 rows, medium space between; the kernels are broad and somewhat rough. The cob is white and of medium size. Pk., 80c; bu., $\$ 3.00$; bag of $21 / 2$ bu., $\$ 6.50$; 10 bu. or more, $\$ 2.50$ per bushel.

\section{IOWA SILVER MINE}

This Corn was originated in Illinois, although first introduced by an Iowa Seed House. It is a pure White Corn with large ears, often measuring 10 to 12 inches in length and weighing as high as one and one-half pounds each. Kernels are quite long, usually rough at the end and the ears are splendidly filled out at the tip. The Corn matures in about 100 days and can be grown any place in Ohio. Pk., 80c; bu., $\$ 3.00$; bag of $21 / 2$ bu., $\$ 6.50 ; 10$ bu. or more, $\$ 2.50$ per bu.

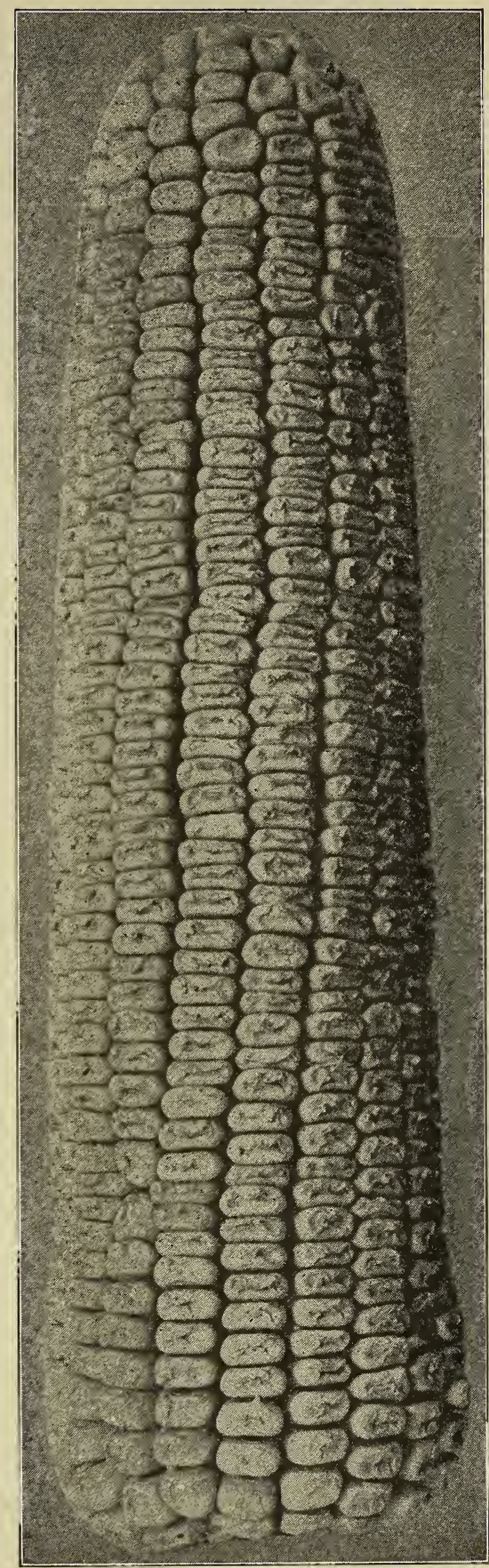

Davis' 110-Day Yellow 


\section{CP2 CORN-Continued WHITE GAP YELLOW DENT \\ A most popular and productive variety. The earliest to mature. \\ This new corn has been more largely advertised than any cther. It is suitable for all soils, grows large ears and matures carly. It grows strong, rank and thick, and it will produce more corn on poor, thin soils than any other kind. It will be appreciated by those living in drought sections, while on strong, rich soil it has no superior. The tip ends of the grains are white, inside yellow, making it a beautiful color. Large growers in the corn belt as well as those out of it will be pleased with this corn. Pk., 80c; bu., $\$ 3.00$; bag of $21 / 2$ bu., $\$ 6.50$; 10 bu., or more, $\$ 2.50$.}

\section{Reid's Yellow Dent.}

This is a very popular variety among the corn growers of Illinois and Iowa. It is almost certain to be seen at all corn shows and fairs, and usually carries off the highest premiums offered. The ear is of excellent shape, nearly cylindrical, tapering gradually to tip, length about 10 inches, kernels firm on cob, eighteen to twenty-four rows with narrow space between rows, color medium yellow with red cob. The ear is quite solid and rather smooth; matures in about 105 days and yields well, although not equal in this respect to some other sorts. Grown quite largely by farmers who take pride in the quality of their corn. We offer a very choice selection of seed. Pk., 80c; bu., $\$ 3.00$; bag of $21 / 2$ bu., $\$ 6.50$; 10 bu. or more, $\$ 2.25$ per bu.

\section{Sweet Corn for Fodder.}

There is nothing better for early fall green feed, or for curing for winter than sweet corn. It has the great merit of being so sweet and palatable that cattle eat every part of the stalk and leaves, and consequently none is wasted. A favorite with dairy farmers. Also excellent for soiling. Can be planted as other corn or sown broadcast. Pk., 75c; bu., $\$ 3.00$; bag of $21 / 2$ bu., $\$ 6.50 ; 10$ bu. or more, $\$ 2.50$ per bu.

\section{Testimoniaís}

Mrs. John Snyder, Jr., Hundred, W. Va., writes: Have just received my Dahlia roots and would say they are fine and so much nicer than I ever expected.

H. E. Douglass, Lore City, Ohio, writes: The seed Corn which I received from you last spring gave me a good yield considering the season and I am very well pleased with my crop of corn. My neighbors say I have the best corn.

Oley M. Long, Tesla, W. Va., writes : Have just receiveú my Grass Seed in first class condition, everything all o. k. Also received your letter with order blanks. Will have another order before very long.

Paul Gartrell, Sherodsville, Ohio, writes: The Potatoes came in good shape and thank you for the extra seeds.

J. W. Hickman, Sisterville, W. Va., writes: The seed arrived in fine condition. You send more than we were expecting free. Many thanks for your kindness. We appreciate it very much.

White Cap Yellow Dent 


\section{OATS}

BIG FOUR

We offer this year carefully grown seed, raised entirely from selected stock. The result of this care in selection is shown in the crom, which is the finest ever grown, and averaging upwards of $80 \mathrm{bu}$. to the acre, so that the seed now offered as the Big Four is the very best and every farmer should renew his stock at once. The grain is white, large and plump, ripens early, has a straw of good strength. It tetters freely and throws up a large number of stems and therefore can be sown thinner than ordinary oats. It is as near rust proof as an ordinary variety can be. Every one who makes Oats should try this variety. An Oats that wil yield 65 to $80 \mathrm{bu}$. to the acre, under average conditions is certainly worthy of general cultivation. Bu., $\$ 1.25 ; 21 / 2$ bu., $\$ 2.40$; 10 bu. or over, per bu., $\$ 1.00$.

\section{REGENERATED SWEDISH SELECT}

(See Illustration)

The Regenerated Swedish Select is the most widely advertised variety, and is sold with great claims at high prices by some firms. It is really a valuable variety, the grain is extra heavy, plump and has a very thin hull which is a pure white. The straw is stiff and strong enough not to lodge. The seed that we have to offer is home grown and we are satisfied it is equal to any offered. We will be pleased to send you samples for inspection and comparison. We know our oats are fully acclimated, are not diseased in any way and believe they will give as good, if not better results than the greatly advertised highpriced seed of this variety. Pk., 40c; bu., $\$ 1.25$; bag of $21 / 2$ bu., $\$ 2.40 ; 10$ bu. or over, $\$ 1.00$ per bu.

\section{AMERICAN BANNER}

A very large, white variety that invariably yields very large crops. It has large, plump, heavy grains and a stiff straw of good strength which is rustproof. Bu., $\$ 1.25$; bag of $21 / 2$ bu., $\$ 2.50 ; 1$ bu. or more, $90 \mathrm{c} ; 100$ bu. or more, $85 \mathrm{c}$ per bushel.

\section{BARLEY}

SUCCESS BEARDLESS

The earliest Barley known. , It grows about the same height as common barley. The straw is stiff and will stand up on any kind of ground. It is a great yielder, yielding invariably from 50 to 75 bushels to the acre. Sow as early as you can, as frost does not hurt it. Pk., 50c; 1/2 bu., $\$ 1.05$; bu. $\$ 2.00$; bag of $21 / 2$ bu., $\$ 3.75 ; 10$ bu. or more, $\$ 1.50$ per bu.

\section{MANSHURY BARLEY}

A six-rowed barley well known and popular. Very productive, hardy, vigorous and profitable. Pk., 50c; bu., $\$ 2.00$; bag of $21 / 2$ bu., $\$ 3.75 ; 10$ bu or more, $\$ 1.50$ per bu.

\section{HIGHLAND CHIEF BARLEY}

This popular two-rowed barley is one of the best of the standard sorts. It is very productive and the berry is large. Pk., 60c.; bu., $\$ 2.00 ; 10$ bu., $\$ 15.00$.

\section{WINTER WHEAT}

\section{PRICES ON APPLICATION IN SEASON ON SEVERAL GOOD KINDS BUCKWHEAT}

Should be sown about the middle of June, broadcast, using from one to three pecks per acre.

\section{NEW JAPANESE}

About a week earlier than Silver Hull, and yields almost as much again. The flour made from it is equal in quality to any other buckwheat, while it is much more productive than any other, and succeeds farther north. As the straw is heavier and it branches more, it does not need to be sown as thickly as other kinds. Prices by express or freight. Pk., 40c.; bu., $\$ 1.50 ; 2$ bu. or more, $\$ 1.25$ per bu.

\section{SILVER HULL}

A very good and popular variety. The grain is of a light gray color, is rounder than the common variety; has a much thinner hull, matures earlier, and yields one-half more to the acre. Price by express or freight. Pk•, 40c.; bu., \$1.50; 2 bu. or more, $\$ 1.25$ per bu.

COULD YOU NOT INDUCE one or two of your neighbors to send with you for seeds? By taking advantage of our discounts it will pay you well for every hour spent, and we will be grateful for your kindness,

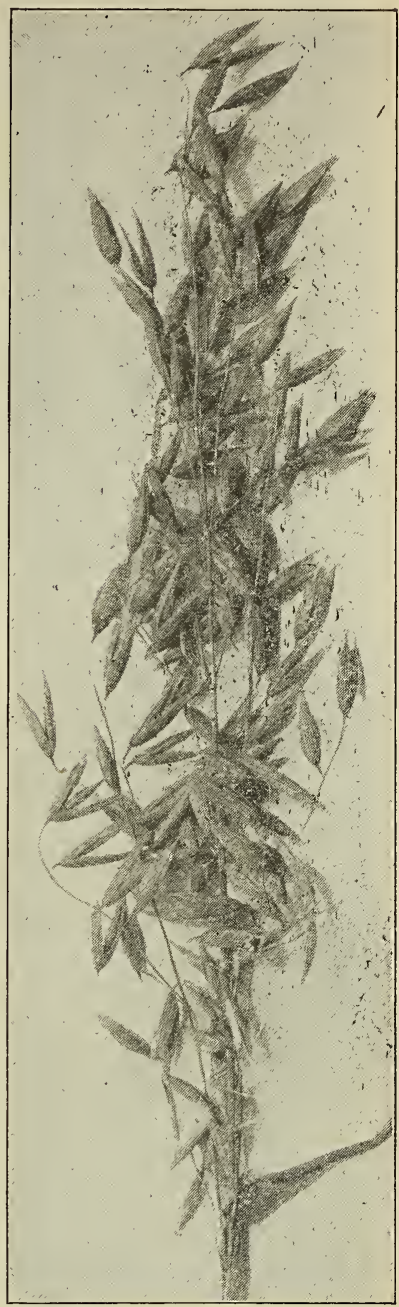

Regenerated Swedish Select

\section{Speltz, or Emmer}

THE VALUABLE NEW GRAIN FROM RUSSIA

It is readily eaten by all kinds of stock, and has shown itself to be especially adapted when fed to milch cows. It is better to $\mathrm{mix}$ it, however, with bran and shorts, as it is a pretty heavy feed when fed alone. As a swine feed we think very well of it, indeed, especially for brood sows. Horses do well on it, but we do not think it is equal to oats in that case. Its most striking value is found in the fact of its drought-resisting qualities. The United States Department of Agriculture has issued a bulletin on Speltz, commending it highly, and the introductory paragraph of that bulletin states: "The extremely variable climate conditions in some of our western states have made it desirable to give particular attention to crops resistant, especially to cold and drought, and it should become one of the prominent crops for stock feeding." Pk., 45c.; bu.,. $\$ 1.50$; bag of $21 / 2$ bu., $\$ 3.25 ; 10$ bu. or more, $\$ 1.25$. 


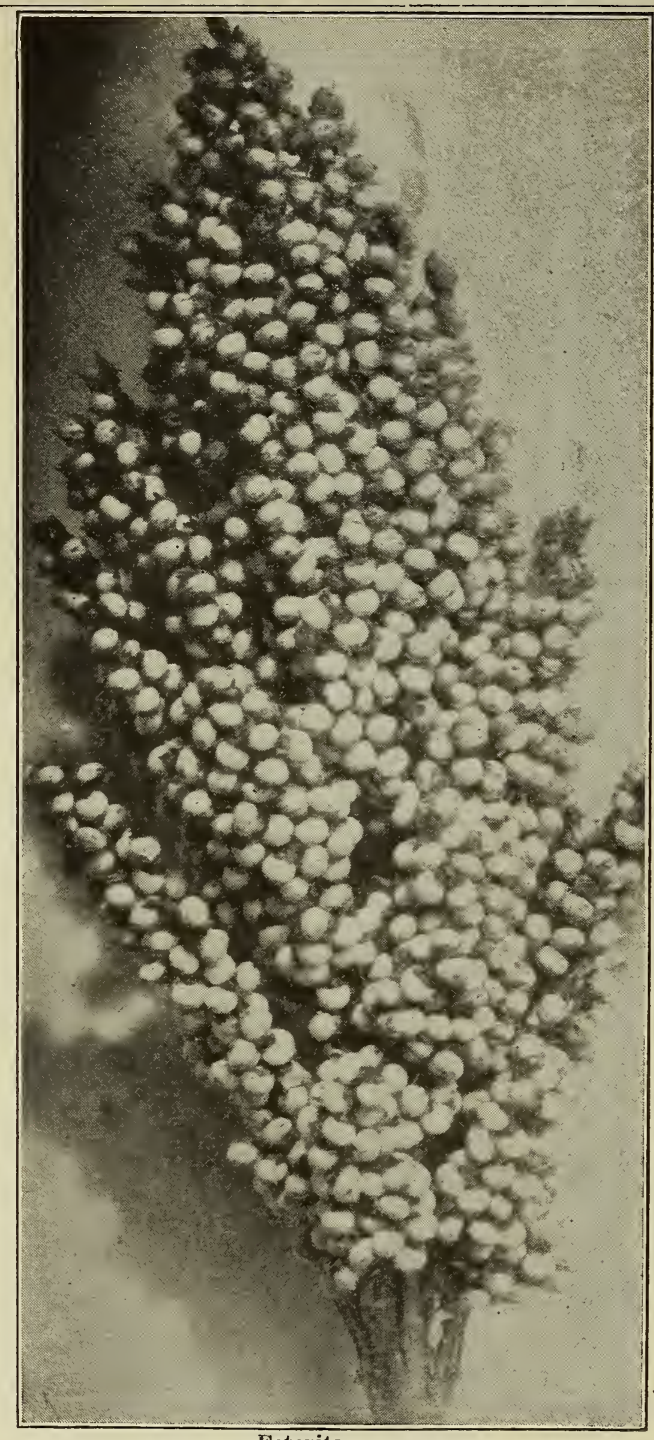

\section{SUDAN GRASS}

\section{(Andropogon Sorghum)}

A Wonderful New Grass, yielding immense quantities of Hay, and especially valuable for Central and Southern States.

Sudan Grass, although not introduced into the United States until 1909, has become very popular in many sections. It produces an immense yield of hay which is nutritious and can be cut twice in a season. In appearance it resembles Johnson Grass, containing larger amounts of protien and fattening qualities. Its principal value is that it is adapted to almost any kind of soil and succeeds in nearly all climates, but produces the largest yields in warm and temperate latitudes, where there is an abundance of rainfall. It does not blight, cures easily, is greatly relished by stock, and can be easily grown if sown either broadcast or in drills. After the first cutting it stools enormously, and as many as a hundred stalks sometimes come from a single root. After frost Sudan Grass is killed, and entirely unlike Johnson Grass, it can be easily gotten rid of, as the winter destroys it entirely.

\section{TYPES OF SORGHUIVIS AND DRY LAND FORAGE PLANTS}

\section{FETERITA}

This is an extra early strain of White Kaffir Corn that we take pleasure in recommending to all poultry men and for all uses that Kaffir Corn can be used for. It is about two weeks earlier than Kaffir Corn, and more productive heads, equally as large; withstands drought as well or better, and branches from the root. One seed usually produces from five to eight stalks, each bearing a full-sized head, all filled with white plump grains a little larger than Kaffir Corn. The stalks are well covered with large blades from the ground up, and after the heads are removed there is about three-fourths as much stover as would be produced by an average corn crop.

Seed planted the first of May will be ready to harvest the last of September. Every poultry keeper should plant a few acres to feed the hens, as it is a sure cropper and one of the best feeds for poultry and pigeons. Owing to its earliness, the best of its class for latitudes south of Chicago. Pkt., 5c. $1 / 4$ lb., 10c.. postpaid. By express or freight, $10 \mathrm{lb}$. 60c.; 50 lb., $\$ 2.50$; 100 lb., $\$ 4.50$.

\section{WHITE KAFFIR CORN}

A favorite grain crop in the West, growing similar to Sorghum. Foliage and stalks, however, do not contain saccharine matter-hence are not so valuable for feeding, but the enormous yield of grain makes it very profitable. The grain is very largely used for poultry and stock feeding, containing a high percentage of starch. Pkt., 5c.; lb., 15c., postpaid. By express, 1 lb., 10c.; $10 \mathrm{lb}$., $40 \mathrm{c}$.; $100 \mathrm{lb}$., \$2.50.

YELLOW MILO MAIZE

Pkt., 5c.; 1 lb., 15c., postpaid. By express, 1 lb. 10c.; 10 lb., 40c.; 100 lb., \$2.50.

\section{SORGHUM, OR SUGAR CANE}

FOR FODDER-Sow 1st to 15th of June, $100 \mathrm{lbs}$. seed per acre, and harrow to cover one to two inches. Harvest after first frost. FOR SYRUP, plant in hills and cultivate same as corn.

\section{EARLY AMBER CANE}

The earliest and makes the finest quality of forage or syrup. 1 lb., 20c., postpail. By express or freight, $1 \mathrm{lb}$., 10c.; $10 \mathrm{lb}$. or over, 6c per lb.; $25 \mathrm{lb}$., $\$ 1.00$; 100 lb., $\$ 3.50$.

\section{EARLY ORANGE CANE}

A strong grower; stalks heavier and a little paler than Amber. 1 lb., 20c., postpaid. By express or freight, $1 \mathrm{lb}$., 10c.; $10 \mathrm{lb}$. or over, $6 \mathrm{c}$ per lb.; 25 lb., $\$ 1.00 ; 100$ lb., $\$ 3.50$.

\section{TEOSINTE}

A wonderfully luxuriant, quick growing forage crop which yields three or four cuttings of fine, nutritious fodder similar to corn fodder. It is extremely popular in southern states, and one of the most profitable crops which can be sown in this section. The foliage is easily cured and resembles corn fodder, but more nutritious. Sow in May in drills three to three and-half feet apart at the rate of three to four pounds per acre. Oz., 10c.; 1/4 lb., 20c. 1 lb., 60c.

\section{CULTURE}

Sudan Grass can either be sown in drills two and one-half to three feet apart at the rate of two to three pounds to the acre, and cultivate like corn, or broadcast fifteen to twenty-five pounds per acre. Seed should be sown about the time of planting corn, and the hay cut when the grass is headed out, with a mower or binder. Early cutting is desirable, as the hay is more nutritious and gives the grass a better chance for large succeeding crops. 1 lb., 50c., by mail postpaid. By express, $5 \mathrm{lb}$. or over, $20 \mathrm{c}$ per $\mathrm{lb}$. 


\section{RAPE \\ DWARF ESSEX}

A forage plant of great merit, easily grown in any part of the United States. It is perfectly hardy and possesses remarkable fattening qualities. One acre will pasture from 30 to 40 head of sheep two months, and lambs will make a gain of 10 to 12 pounds a month. To use the com. mon expression: "They will soon weigh like lead." While it is the ideal food for sheep, still it is of equal value for cattle and hogs, as they are very fond of it. Rape is a rank grower and should have heavy manuring as well as good cultivation. Any soil that will grow corn will grow rape. Sow the. seed about the middle of June. Will resist the drought and the crop can be fed when it is most needed. By sowing different pieces several weeks apart a continuous supply of good feed can be had. When sown in June it should be fed during August, though if the first crop were cut about four inches above the ground it will make a second growth that will be useful aftertime. It does well with oats in the spring. If soil is rich and clean, sow broadcast; but on most land it will pay to sow in drills 30 inches apart. and cultivate once or twice to keep down deeds. When sown broadcast use $5 \mathrm{lbs}$,, and if in drills $2 \frac{1}{4} \mathrm{lbs}$. per acre. 5 lbs. or more, 12c per lb.; $25 \mathrm{lbs}$., $\$ 2.75$; 50 lbs., $\$ 6.00 ; 100$ lbs., $\$ 9.75$.

\section{MILLET}

Largely used as a summer hay crop and particularly adapted for rich bottom soils; also very useful for cleaning rich, foul lands of weeds, as its quick, abundant, luxuriant growth smothers most weeds.

Prices subject to change without notice.

\section{GERMAN MILLET \\ (Tennessee Cultivated)}

Far superior to western grown. Will grow in any climate or soil, and make a large yield of most nutritious feed. Prepare the ground well before sowing; sow not less than 50 lbs. per acre at any time between May 1st and June 15th. Cover with a single stroke of a light harrow, or roll without harrowing, or it may be sown with a wheat drill, barely covering the seed. Cut the crop while in bloom, before the seed hardens. (Bu., 50 lbs.) 1 pk., $75 \mathrm{c} ; 1 \mathrm{bu}$, $\$ 2.00$.

1 pk., 50c; 1 bu., $\$ 1.50$.

\section{HUNGARIAN MILLET}

A valuable forage plant of the Millet family, but not so coarse. Sown and cultivated same as Millet. (Bu., 48 lbs.) 1 pk., 50c; 1 bu., $\$ 1.50$.

\section{PEARL MILLET}

Sown in drills four feet and cultivated like corn. The plants attain a height of eight to ten feet, with

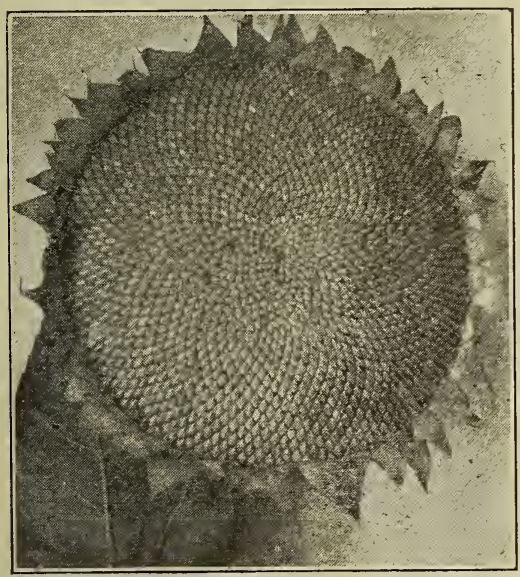

Mammoth Russian Sunflower
The earliest variety grown. The pods are small and remarkably solid, well filled, and of an extra fine quality. Yield per acre very large. $1 \mathrm{lb.}, 30 \mathrm{c}$; by express, $10 \mathrm{lbs}$. or over, $15 \mathrm{c}$ per $\mathbf{l b}$.

\section{SUNFLOWER}

\section{CULTURE}

Plant from the end of April to the 1st of June in rows three and one-half feet apart, dropping two seeds fifteen inches apart. Cultivate as for corn. When ready to harvest, the heads are cut and flailed after being thoroughly dried. Requires about $1 \mathrm{pk}$. per acre.

\section{MAMMOTH RUSSIAN}

A profitable crop, largely grown in this and many other sections for poultry feed. Unfortunately, many of the sunflower producing sections are affected with a fly which stings the seed in blossom, producing weevil which cut holes in the seed and ruin it.

Sunflower is particularly adapted to good, rich soil, and alluvial bottoms (not overflowed) will grow it successfully. The yield is from 800 to 1,200 lbs. per acre, which sells at from three to four cents per pound, according to the demand. Indications are that fair prices will prevail next season on account of the war cutting off the Russian supply. This year prices are higher than usual. $1 \mathrm{lb}, 20 \mathrm{c}$; by express, $10 \mathrm{lbs}$. or over, $10 \mathrm{c}$ per lb. 


\section{SOJA BEANS}

The Soja Beans are fast taking the place of Clover in sections where the soil is not the most fertile, both for hay and for fertilizing purposes. Recommended as the best leguminous plant for soil restoring, as it is adapted to all soils. It is one of the most nutritious of all vegetable products. It will produce a crop of from 15 to 30 bushels of seed per acre and is as easily grown as common beans. For pasturing or feeding as green fodder it is very valuable and is fully equal to clover for fertilizing the ground. The dry beans when ground make an excellent meal for feeding milk cows. When roasted and ground makes an excellent substitute for coffee. For hay or silo purposes, sow one bushel per acre, either broadcast or drilled, and cut when in blossom. For seed sow in drills about 12 inches apart in the row and have the rows about thirty inches apart.

\section{EARLY YELLOW OR SANITO} (See Illustration)

The best variety for planting in the Northern and Eastern States. Ripens early and produces a good crop of vines and pods. Lb., 20c; pk., \$1.00; bu., $\$ 3.75$.

\section{EARLY BLACK}

Largely grown in parts of Michigan and Wisconsin. Lb., 20c; pk., $\$ 1.00$; bu., $\$ 3.75$.

\section{EARLY BROWN}

One of the best varieties for Central and Northern Ohio and Pennsylvania. Lb., 20c; pk., $\$ 1.00$; bu., $\$ 3.75$.

\section{MEDIUM GREEN}

Very productive. Highly recommended by the Ohio Experiment Station. Lb., 20c; pk., $\$ 1.00$; bu., $\$ 3.75$.

\section{MAMMOTH YELLOW}

Valuable in the Southern States as a forage crop and for fertilizing; also for hay, feeding green and silo purposes in the Central States. Lb., 20c; pk., 90c; bu., \$3.25.

\section{COW PEAS}

More Cow Peas are planted every year as the farmer realizes their great value as a soil enricher. The plant is a legume, and through the agency of the nitrogen-producing bacteria on its roots adds this valuable plant food to the soil much cheaper than it is possible to obtain it in any other way. Cow Peas also make excellent hay and should be cut and cured the same as clover. After harvest the stubble, with its after growth, may e turned under as a fertilizer. If Kaffir Corn is sown with the Cow Peas, it will hold them off the ground so that the Cow Pea Vine can make a better growth.

The Cow Pea must have a warm-almost sandysoil when grown in the North. Where never grown before, the best results may be had in drilling the seed and cultivating at first as for Field Beans, the growth at first being quite low. Weeds get a start of the Cow Peas unless kept down.

\section{WHIP-POOR-WILL}

A great favorite in the North and West. Very productive. Pk., 90c; bu., $\$ 3.25$.

\section{EARLY BLACK}

A prolific vine-growing variety of merit; seed often sold for table use. Pk., $\$ 1.00$; bu., $\$ 3.75$.

\section{CLAY}

This variety is of extra strong growth and most productive of dry seeds. Seed of a large blue color. Pk., 75c; bu., $\$ 2.75$.

\section{PEAS}

\section{WHITE CANADA FIELD}

Every year there is more inquiry for Field Peas. They stand in the front rank as a fodder crop, especially for hogs. They can be fed green or dry. As a fertilizer they come next to clover, to be plowed under when they commence to blossom. They will grow on land that will not produce clover. Sow $11 / 2$ to 2 bushels of each. Sow the peas first and plow under 4 to 5 inches; then oats on top and harrow in. Pk., 80c; bu., \$3.00.

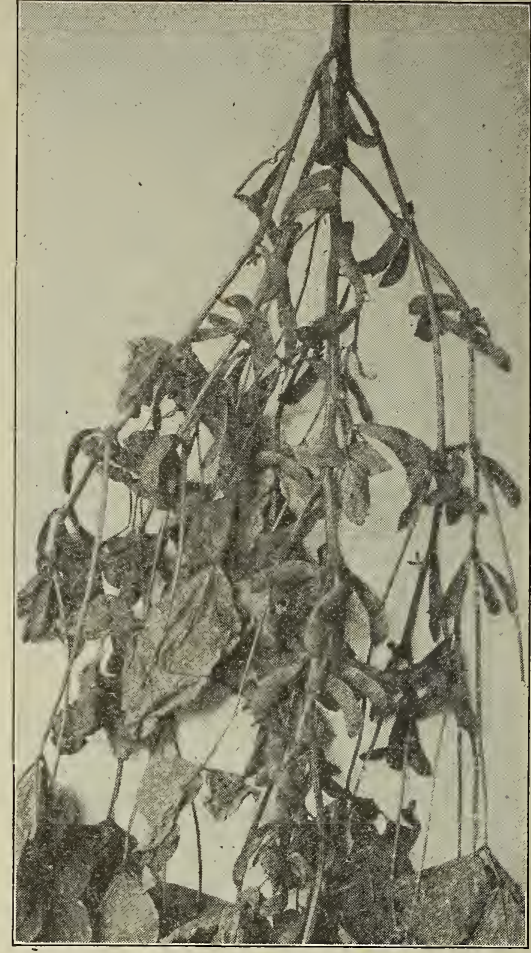

Early Yellow Soy Beans

\section{VETCHES}

SPRING

Sown broadcast at the rate of one to one and a half bushels to the acre, like wheat or barley, and sometimes mixed with oats for soiling. Used in France and Canada as a substitute for peas. It is also ground up into flour, after which it is mixed with wheat flour for making bread. A valuable plant. Market price.

\section{SAND WINTER OR HAIRY (Vica Villosa)}

This variety thrives on poor, arid, sandy soil. It is sown either in fall or in the spring, and generally mixed with rye, which serves as a support to the plants. The seed is black and perfectly round and should be sown at the rate of one and one-half bushels to the acre. (See illustration on page 36 .) Qt., 45c; bu., 8.50 , by express.

\section{Notice}

Prices on Field Peas, Cow Peas, Soja Beans are changing about daily, so that we are unable to quote prices which will be invariable. Do not fail to write for prices before buying. Bags to ship in $20 \mathrm{c}$ each.

\section{Testimonials}

Geo. S. Loucks, Alverton, Pa., writes: The Davis' Golden Mammoth Corn I bought from you did very well from 21 acres. We put up 90 tons ensilage and husked 1,200 bushels corn, which we think was very good considering the dry season. 


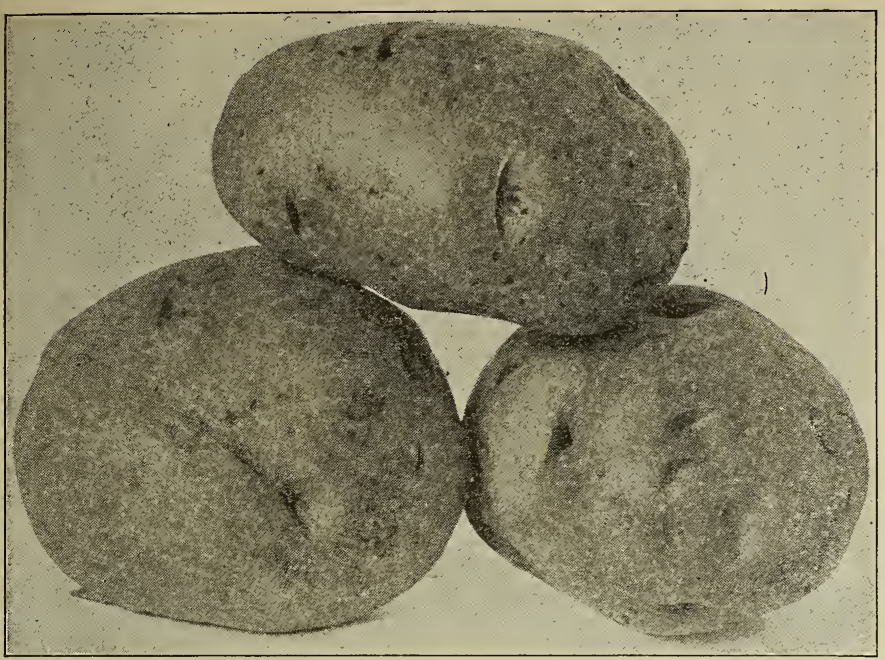

Irish Cobbler

\section{SEED POTATOES}

It will pay progressive farmers to plant the best Seed potatoes, even at the high prices we are obliged to charge for the seed. Not only will these varieties make a larger yield of the finest potatoes that would bring the best price on market, but also there is sure to be a great demand for Seed Potatoes at remunerative prices from many neighbors who see these potatoes. Our seed potatoes this season, as usual, have been grown carefully, and especially for Seed, and are now stored in fine condition in our cellars. All orders accompanied by cash are promptly acknowledged, and the potatoes forwarded as soon as the weather permits. Please state whether we shall ship by freight or express. At the prices below we make no extra charge for barrels, boxes, bags or cartage. In case of changes special prices will be given by letter. The varieties named below are now the most profitable and popular varieties in cultivation.

\section{SENECA BEAUTY}

A potato which is very smooth, uniform size; almost blight proof; productive; splendid quality; fine keeper. A grand new medium late potato, and too much has not been said in its praise. Its beautiful and distinct appearance sells it in any market, and its fine table qualities please all. The tubers are large and smooth, with few eyes close to the surface, and of a beautiful pink color. Uniform in size and shape, scarcely any small ones. Vines rank and healthy, loaded with beautiful blossoms. Good keeper and a heavy cropper. Pk., 50c; bu., $\$ 2.00 ; 10$ bu.. or more, $\$ 1.75$ per bu.

\section{RURAL NEW YORKER}

A valuable variety of large size, very smooth, and a great cropper. In quality it is unexcelled. It is the best late long keeper and is highly recommended. More poattoes of this sort are shipped annually than any other variety, and their large, handsome appearance makes them more profitable than any other variety. Pk., $40 \mathrm{c}$; bu., $\$ 1.60 ; 10$ bu. or more, $\$ 1.50$ per bu.

\section{EARLY OHIO}

A general favorite; too well known to need description. Pk., 50 c; bu., $\$ 1.75 ; 10$ bu., or more, $\$ 1.60$ per bu.

\section{BLISS TRIUMPH}

The earliest variety in existence. The tubers are not large, but are of nice medium size for early use, round as a ball and of beautiful color. This variety has been very popular for several reasons in the Southern States, and hundreds of cars are shipped to the Northern markets and bring fancy prices. There is always such a demand for them that the seed is scarce. We do not recommend them for main crop. Pk., $50 \mathrm{c}$; bu., $\$ 2.00 ; 10$ bu. or more, $\$ 1.80$ per bu.

\section{WHITE OHIO}

This variety has all the good qualities of its parents, the Early Ohio, and the additional one of being white with a slight tint of rose around the eyes. For an early notato (and it is claimed to be the earliest grown) it is a desirable one in every respect. Pk., 50c; bu., $\$ 2.00 ; 10$ bu., or more, $\$ 1.80$ per bu.

\section{IRISH COBBLER}

\section{(See Illustration)}

A very productive variety, being about as early as the Early Ohio. Tubers round, somewhat flattened, stem end square, skin and flesh white, fine grained and dry. Pk., 50c; bu., $\$ 1.75 ; 10$ bu. or more, $\$ 1.60$ per bu.

CARMEN NO. 3

This handsome new main crop potato is of large size; yielding immense. crops of uniform size and shape. It is of perfect form, almost every potato being of the same size and shape, averaging nearly one pound in weight in good season. The skin and flesh aré extremely white, and its cooking qualities are very fine. It is a remarkably handsome potato, enormously prolific, and will please all potato growers. Keeps well. Pkt.. $40 \mathrm{c}$; bu., $\$ 1.60 ; 10$ bu. or more, $\$ 1.50$ per bu.

\section{DAVIS “ELM VALLEY” SEEDS ARE OF DEPENDABLE QUALITY}

We are offering you this season, as in former years-"The 'Best by Test." Kindly remember when looking through this catalogue that you are taking no chances in buying anything we offer, because the value, purity, type and germination have been proven, not guessed at. Our seeds will give you the results aimed at; if they are not entirely satisfactory in spite of all precautions, kindly write us. We make every effort to help our customers over difficulties and are placing before you our list of varieties which we ourselves can rely upon.

This year we are better qualified to give you efficient service which embodies promptness in filling the orders; reliability of those who have charge of them; quality of the seeds supplied and various other factors of almost equal importance. Being located in the center of Ohio enables us to reach all points promptly and it is our aim to ship all orders the day after they are received. Constantly we are working to perfect our system, that we may forward every order whether large or small in the minimum time. 


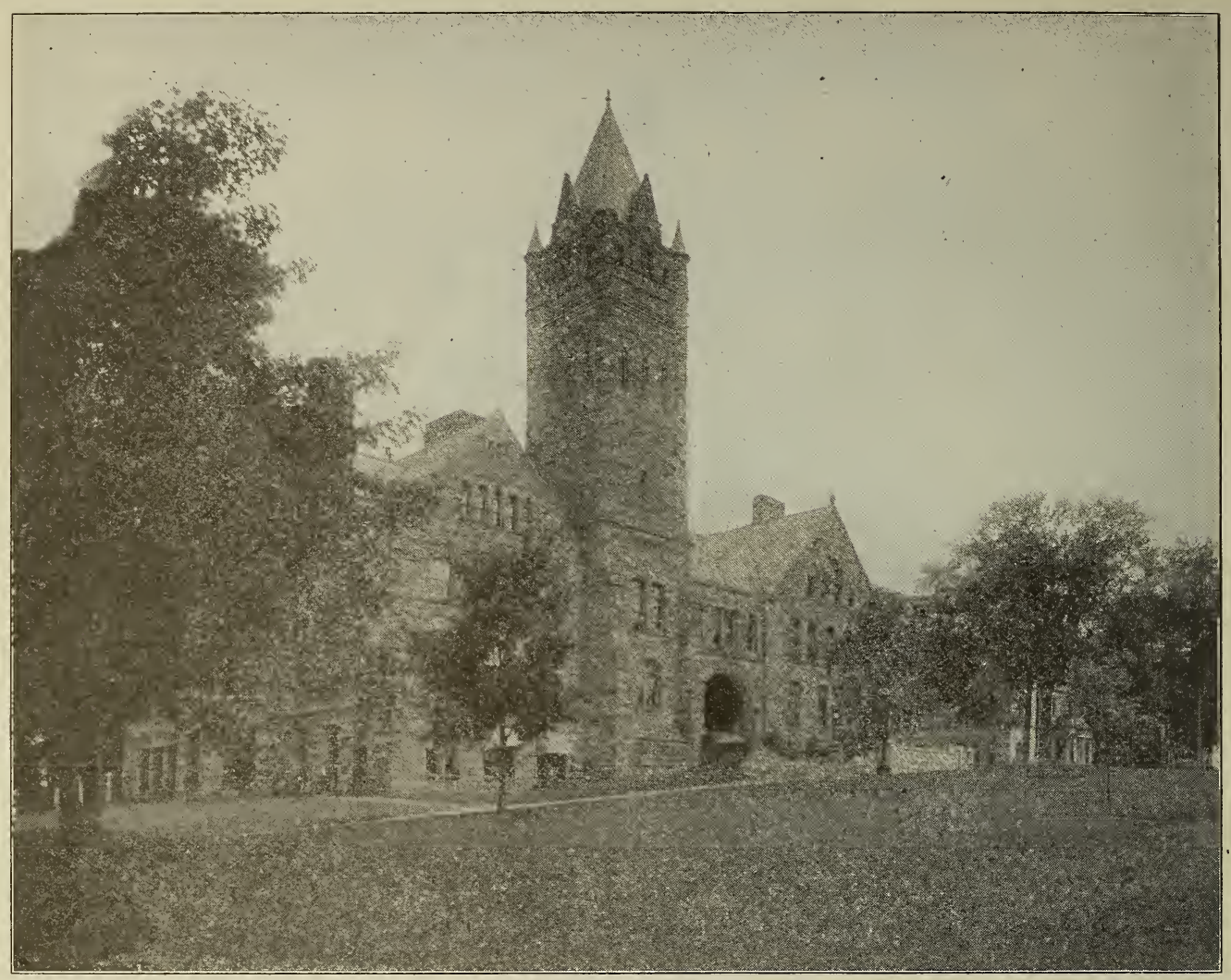

\section{LAWN GRASS SEED}

For a fine lawn you should have a well drained, rich soil, that should be carefully prepared, making it as fine and smooth as possible. After you have the ground prepared, the first improtant part is the wise selection of the seed, which should be a mixture of varieties that would make a fine growth at different seasons of the year. Some varieties make a luxuriant growth in the spring, others in the summer, and others in the autumn. A combination of the proper varieties is required for a perfect carpetlike lawn the entire summer.

The ground should be dug up or plowed about ten to twelve inches deep, and then it should be harrowed and rolled and graded until it is perfectly fine and level, all stones and pieces of sod must be removed to get it in good shape for a lawn. In order to start the grass luxuriantly, the ground should have a good dressing of well-rotted manure or pulverized Sheep Manure; sheep manure preferred, as it does not contain any weed seed and is ground fine; should be applied at the rate of 5 to 10 pounds for 200 sq. ft. One ton per acre is none too much if the ground is not rich.

Seed can be sown either in the spring, from February to May, or in the fall, from August to October. Quantities are given below. It should be put on as evenly as possible, and half had better be sown one way, then crossing, sowing the other half at right angles. Covering can be done with a smoothing harrow (if in large areas) or with a hand rake (if in small plots), and rolling with a heavy roller will be decidedly beneficial.

QUANTITIES TO USE

FOR NEW LAWNS-1 lb for $400 \mathrm{sq}$ ft ; $25 \mathrm{lbs}$. for $11,000 \mathrm{sq}$. ft.; $80 \mathrm{lbs}$. to $100 \mathrm{lbs}$. for 1 acre.

FOR RENEWING OLD LAWNS-1 lb. for 700 sq. ft. ; 50 lbs. for 1 acre.

DAVIS' VELVET SOD LAWN MIXTURE

Nothing adds more to the attraction of a home than a nice, clean, well-kept, velvety lawn. Thousands of dollars are annually spent for sodding that might have been saved and better results obtained by the use of choice mixture of lawn seed. Our Velvet Sod Lawn Grass is composed exclusively of the best varieties of grass, such as experience has shown to be best adapted to procure a thick, heavy, carpet-like lawn. In this mixture we use only the very best recleaned seed, and it is equal to any variety sold under any name. One of the greatest troubles in obtaining a good lawn is to get it free from weeds. These, while not always in the seed, but quite often in the ground or come from the use of stable manure, are nevertheless objectionable. Our customers can rely in buying our lawn seed on its being the very purest seed obtainable and entirely free frum weeds or foreign seed. By mail, postpaid, $1 \mathrm{lb} ., 50 \mathrm{c}$; 3 lbs., $\$ 1.25$; by express, $1 \mathrm{lb}$., $35 \mathrm{c} ; 5$ lbs., $\$ 1.50 ; 20$ lbs. or over, $25 \mathrm{c}$ per lb.

\section{SHADY SPOT MIXTURE}

On nearly all lawns there are shaded, bare and unsightly spots on which the owners have difficulty in getting a stand of grass. This mixture is composed of grasses that naturally grow in the shade and is especially suited for shady places. They are the finest and most costly of all grasses, several of them being imported grasses. If the soil is sour and covered with moss and out of condition, rake off the surface and apply slacked lime at the rate of 100 pounds per $1,000 \mathrm{sq}$. ft. This will sweeten the soil. Then dig and prepare the lawn as directed. By mail, 1 lb., 60c; 3 lbs., $\$ 1.40$; by express, 1 lb., 45c; 5 lbs., \$2.00. GOLF LINKS MIXTURE

We make a mixture of grasses suitable to the purposes of the golf links, so it will stand rough usage. We can also prescribe for links located on poor or rich, dry or wet soils, telling which grass will suit each location best. By mail, 1 lb., 60c; 3 lbs., $\$ 1.40$; by express, 1 lb., 45c; 5 lbs., $\$ 2.00 ; 20$ lbs. or over, $35 \mathrm{c}$ per lb.

TENNIS COURT MIXTURE

A mixture composed of low-growing hardy grasses suitable for ground of this character. Mail, $1 \mathrm{lb}$, 60 ; 3 lbs., \$1.40; express, 1 lb., $45 \mathrm{c} ; 5$ lbs., \$2.00; 20 lbs. or over, 35c. 


\section{GRASSES}

Prices on grasses are changing almost daily, so that we are unable to quote prices which will be invariable. Do not fail to write for prices before buying. If you are in a hurry for the seed, you can order it and we will send seed to full value of money sent. If to be sent by mail, add extra postage. Bags to ship in 20 cents extra.

\section{BROMUS INTERMUS}

This wonderful new grass, of comparatively recent introduction in the country, has been very highly recommended by the U. S. Agricultural Department and by grass specialists in all parts of the country. It will produce a wonderful crop of hay on land which is too poor for clover or timothy. It resists intense cold and also the most hot, dry weather. Every farmer and stock raiser should give it a trial. Seed should be sown early in spring, using 20 to $25 \mathrm{lbs}$. per acre (if sown alone), or if sown with alfalfa, use $12 \mathrm{lbs}$., with 8 lbs. alfalfa. $1 \mathrm{lb.,} \mathrm{20c;}$ 1 bu. (10 lbs.), $\$ 1.75$.

\section{TIMOTHY}

No variety of our natural grasses is more cultivated than Timothy; and for meadows it is valuable. It is best suited to moist, rich, strong and loamy soils, where it grows to perfection. It is very nutritious and makes good hay, but should be cut at time of flowering. Sow $11 \mathrm{lbs}$. per acre. $1 \mathrm{lb}$., 15c; 1 bu. (45 lbs.), $\$ 4.50$.

\section{KENTUCKY BLUE GRASS}

Very valuable and exceedingly popular with some sections of the country. It is unexcelled for lawns. Sow $14 \mathrm{lbs}$. per acre for pasturage; 40 to $60 \mathrm{lbs}$. per acre for lawns. 1 lb., 20c; 1 bu. (14 lbs.), \$1.65.

\section{RED TOP}

Grows well on almost any soil, but best on low land, and produces a very firm sod. Fancy clean seed. (Weight about 42 lbs. per measured bu.) 1 lb., 20c; 100 lbs., \$15.00.

\section{ORCHARD GRASS}

Valuable for pastures in shady places, as in orchards. When sown alone sow three bushels to the acre. 1 lb., 20c; 1 bu. (14 lbs.), \$2.50.

\section{MEADOW FESCUE}

A most valuable grass for pasture and affords good crops of hay where particularly suited. It grows best on low, damp soil, and is especially desirable for all permanent pastures. 1 bu. (24 lbs.), \$3.00.

\section{PERENNIAL, OR ENGLISH RYE GRASS}

A quick growing grass wihch is most suitable for mixtures, both pastures, hay and lawns. Succeeds well on almost any soil not water sogged and affords good, quick, nutritius grazing. If alone, requires $1 \frac{1}{2}$ bu. per acre. In mixture, from 2 to 3 pks. per acre. 1 lb., 20c; 1 bu., $\$ 2.50$.

\section{PACY'S IMPROVED SHORT RYE GRASS}

Similar to above, except that it does not grow quite so tall and is superior for lawns and fine pastures to Perennial Rye Grass. 1 lb., 20c.

\section{ITALIAN RYE GRASS}

Biennial. Height, 18 to 30 inches. As it is not perennial, it is not adapted for permanent pastures, but for one or two years its hay is unsurpassed. Sow, if alone, $55 \mathrm{lbs}$. per acre; $18 \mathrm{lbs}$. per bu. 1 lb., 15c; 100 lbs., $\$ 10.00$.

\section{CANADIAN BLUE GRASS}

Also called flat stem poa, Flat-stalked Meadow Grass. Grows a foot or more high. Recommended for horses, cows or sheep. Thrives well on clay. Sow 30 lbs. per acre. 1 lb., 20c; 1 bu., \$1.40.

\section{BERMUDA GRASS}

A valuable grass for the South and for tropical climates; will not endure frost. Sow 6 to 8 lbs. per acre. 1 lb., 75c.

\section{CREEPING BENT GRASS}

Valuable in mixture with other grasses for lawns, etc. Suitable also for moist localities. (12 lbs. per bu.) Sow 30 lbs. per acre. 1 lb., 30c; 1 bu., $\$ 3.25$.

\section{CRESTED DOGSTAIL}

Perennial. Height, 12 to 18 inches. An excellent grass for hard, dry soils; valuable for pastures and lawns, as it is very hardy, tender, nutritious, and relished by all stock. (21 lbs. per bu.) Sow, if alone, 35 lbs. per acre. 1 lb., 40c; 1 bu., $\$ 7.40$.

\section{HARD FESCUE}

Perennial. Height, 12 to 24 inches. Thrives well in dry situations. The herbage is decidedly tender, but the flower heads, when ripe, become hard. Sow, if alone, $30 \mathrm{lbs}$. per acre. (12 lbs. per bu.) $1 \mathrm{lb}$., 35 c; 1 bu., $\$ 3.50$.

\section{SHEEP'S FESCUE}

Perennial. Height varies from 6 to 20 inches. Grows naturally, on light, dry, sandy soils. Sheep are very fond of it. Sow $30 \mathrm{lbs}$. per acre. (14 lbs. per bu.) 1 lb., 35c; 1 bu., $\$ 4.00$.

\section{FINE-LEAVED FESCUE}

Perennial. Height varies from 8 to 24 inches. Similar to the Sheep's Fescue mentioned above, except that the leaves are much finer. Sow, if alone, 40 lbs. per acre. (14 lbs. per bu. 1 lb., 50c; 1 bu., $\$ 5.50$.

\section{RHODE ISLAND BENT GRASS}

A fine grass, chiefly used for pastures and lawns, for which it is one of the best. Sow $40 \mathrm{lbs}$. per acre. (12 lbs. per bu.) 1 lb., 35c; 1 bu., $\$ 3.50$.

\section{TALL MEADOW OAT GRASS}

Perennial. Has broad, flat leaves, and grows about 3 feet high. Has an abundance of long, fibrous roots penetrating deeply in the soil, enabling it to withstand drought and cold. Sow 25 to $50 \mathrm{lbs}$. per acre. 1 lb., 35c; 100 lbs., $\$ 25.00$.

\section{WOOD MEADOW GRASS}

No grass is better adapted for pleasure grounds, particularly under trees, as it will not only grow in such places, but forms a fine sod where few other grasses can exist. Sow 25 lbs. per acre. 1 lb., 50c; 100 lbs., $\$ 40.00$. 


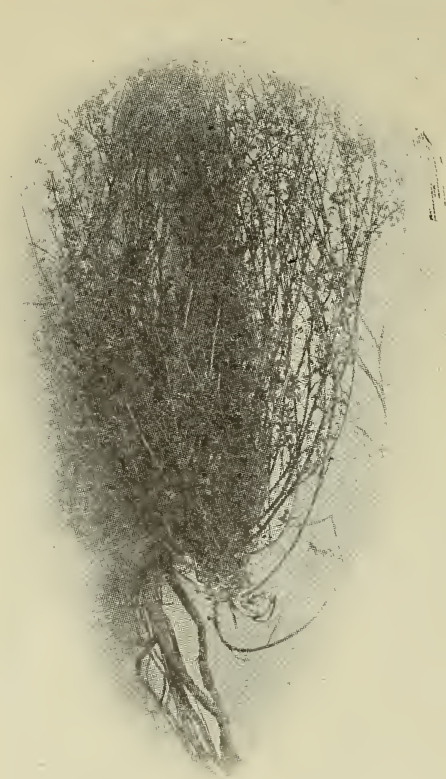

Alfalfa

\section{BOKHARA OR SWEET CLOVER}

This important Clover is suited to any and all classes of soil and especially desirable on loamy, sandy or alluvial soils. Formerly it was used mostly for waste lands, but many prominent stock raiser:3 are using it extensively for both pasturage and hay, in many cases abandoning Alfalfa and substituting Sweet Clover.

Sweet Clover is of vigorous growth and withstands extremes of heat and cold, as the tap roots penetrate the soil very deeply, and it does well on both barren hillside as well as on bottom land. Matures early. Can be cut two or three times in a season; has a delightful and sweet-scented odor, and the blossoms are particularly good for bees.

We offer below three classes:

\section{WHITE SWEET CLOVER}

A biennial growing five to six feet high, having white blossoms borne in large panicles and extremely sweet scented. Reseeds itself if not disturbed or not cut in bloom.

HULLED SEED-Requires 12 to 15 lbs. per acre. $1 \mathrm{lb.}, 30 \mathrm{c}$; 1 bu. (60 lbs.), $\$ 15.00$.

UNHULLED SEED-1 lb., 20c; 1 bu. (30 lbs.), $\$ 5.50$.

\section{YELLOW SWEET CLOVER}

A Perennial, not quite so tall growing as the White, but more desirable for pasture, as the life season is much longer, producing an abundant yield of forage. Unhulled seed. 1 lb., 30c; 1 bu. (30 lbs.', $\$ 5.50$.

\section{ANNUAL YELLOW SWEET CLOVER}

A variety indigenous to western states; grows similar to the Perennial and Biennial varieties. Sown in many sections for innoculation and pastures. Cleaned seed. 1 lb., 15c.; 1 bu. (60 lbs.), \$5.00,

\section{MAMMOTH OR LARGE RED CLOVER}

It grows five to six feet high, but its stalks are so coarse and large that stock will eat only the leaves. By its judicious use, lands which have been exhausted may be reclaimed, as it will grow where the common clover will fail. Sow 15 lbs. per acre. (Bu., 60 lbs.) 1 lb., 30c; 1 bu., $\$ 15.00$.

\section{WHITE DUTCH CLOVER}

A small creeping Perennial, valuable for pasturage and for lawns. It accommodates itself to a variety of soils, but prefers moist ground. Sow in spring at the rate of six pounds per acre, or when used with other grasses, half that amount. 1 lb., $60 \mathrm{c}$.
CLOVERS

wing to the European war the prices on Clover and Grasses have been very erratic. Prices given below represent a fair marvalue when this book is printed, and are subject to change ou are in a hurry for the seed, you can order it and we will send seed to full value of money sent. If to be sent by mail, add extra cents extra.

\section{ALFALFA}

ne of the most valuable forage plants. It will adapt itself to lmost any land that will grow clover, but thrives best on deep, ality, relished by all stock, and of special value to the dairy farmer. Though a wonderful cropper, it does not impoverish the les it to withstand extreme drought, which often makes it a another season, but put in a trial acreage this spring. well prepared seed bed, free from weeds, is essential for best GAKOTA GROWN SEED-1 lb., 30c; bu., \$15.50. IDAHO and DNTANA SEED—1 lb., 30c; bu., \$15.00. AMERICAN GROWN

Extremely hardy. Especially suitable for northern latitude. GRIMM ALFALFA tity to offer. Write for prices.

VARIEGATED OR COSSACK ALFALFA

RIAN variety of Alfalfa that has the same underground rown and branching roots that the Grimm Alfalfa has, and is claimed to be just as hardy and will produce a little more hay than has one advantage over Grimm in that it can easily be distinguished from common alfalfa by its blossom which varies from light yellow to a dark purple. If this variety proves to outyield Grimm, it will supplant that variety as soon as seed becomes plentiful enough. Our supply of this variety is very limited. Write for prices.

\section{ALSIKE}

A very hardy clover; good for pasture and hay. Does especially well on low or moist land. 1 lb., $25 \mathrm{c} ; 1$ bu., $\$ 13.00$.

\section{CRIMSON CLOVER}

A quick growing annual. Desirable for pasture or to plow under. Where the winters are not too severe, should be seeded in the fall, about $15 \mathrm{lbs}$. to the acre. 1 lb., 15c; 1 bu., $\$ 7.00$.

\section{MEDIUM RED CLOVER}

This is by far the most important of all the varieties for practical purposes. Sow in spring or fall, at the rate of 8 to $12 \mathrm{lbs}$. per acre. More is required on old, stiff soils than on new and lighter ones. (Bu., 60 lbs.) 1 lb., 30c; 1 bu., $\$ 15.00$.

\section{JAPAN CLOVER}

This has been widely used throughout the southern states and east of the Mississippi River, and in many places now grows indigenously. It affords splendid pasture, grows very thickly, and is particularly adapted to waste lands and woodland pastures, and it succeeds fairly well on poor soils. When once established it spreads rapidly and usurps other wild growths, in many cases even subduing Broomsedge. It is not regarded as a pest, as it can be readily gotten rid of by plowing it up, and acts as an excellent fertilizer to the soil.

In the South, Japan Clover makes fairly good hay, and is extensively used in some sections for this purpose. It is nutritious, fattening, and readily eaten by cattle.

To obtain a good stand it is only necessary to scatter the seed broadcast in the spring, during March, April or May, at the rate of ten to twelve pounds per acre. If the land can be harrowed over before sowing, it is of course better, but this is not absolutely necessary. 1 lb., $30 \mathrm{c} ; 1$ bu. (25 lbs.), $\$ 5.00$.

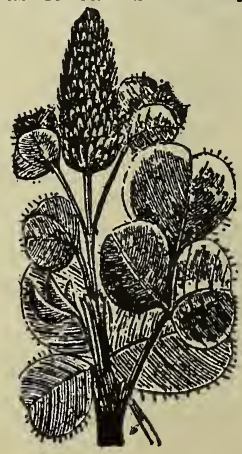




\section{DAVIS’ SELECT FLOWER SEEDS}

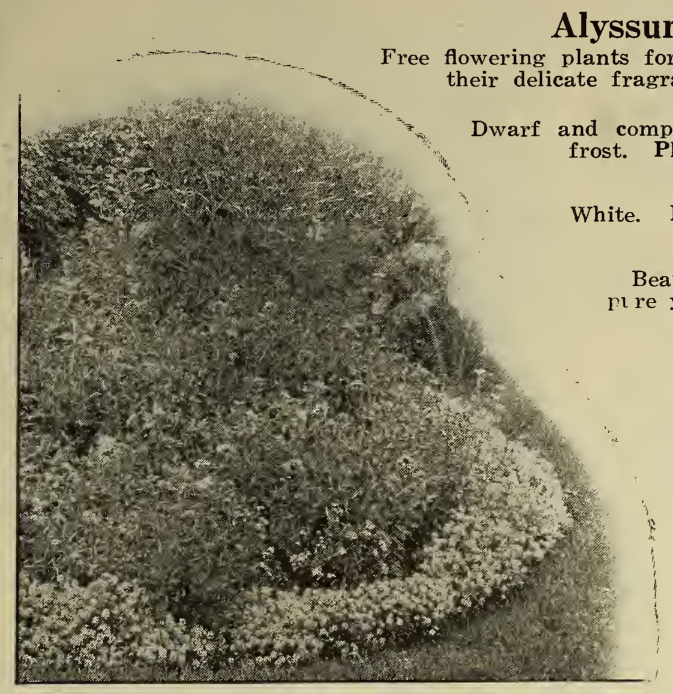

Sweet Alyssum

\section{ALYSSUM SWEET, LITTLE GEM}

ALYSSUM SWEET, LITTLE GEM
act, with plants a mass of white from spring until

\section{ALYSSUM SWEET}

(See Illustration)

ALYSSUM SAXATILE

(Hardy Alyssum)

Beautiful spring-blooming variety, with flowers of a deep re yellow. Pkt., 5c.

\section{Amaranthus}

These plants afford brilliant contrasts of color, being useful for tall borders and groups, also where foliage effects are desired. The leaves and stems are of different shades of red, blended usually with green; two to three feet high. Seed may be sown in open ground early in spring, covering one-fourth inch deep; thin two to three feet apart.

\section{CAUDATUS TRICOLOR}

(Joseph's Coat)

Leaves red, yellow and green. 3 ft. Pkt., 5c.

$$
\text { CAUDATUS }
$$

(Love-Lies-Bleeding)

Dark drooping flowers; spikes, 2 ft. Pkt., 5c.

\section{Acroclinium}

\section{(Everlasting)}

A very pretty, half-hardy annual, producing white and rose-colored, double- daisy-like flowers, about one and one-half inches in diameter. These are "Immortelles," so desirable for wreaths and winter bouquets. Sow the seed in open ground early in spring. preferably in light, well prepared soil, and cover with one-fourth inch of fine soil firmly pressed down. Thin the young plants to four inches apart. Height fifteen inches.

\section{Agrostemma}

A hardy plant introduced from Russia; blossoms similar to pinks. Suitable for border plants; fine for bouquets or cemetery. Mixed colors. Pkt., 5c.

$$
\text { ALBUM }
$$

Pure white. Oz., 20c; pkt., 5c.

$$
\text { ROSEUMM }
$$

Ligth rose. Oz., 20c; pkt., 5c.

Oz., 20c; pkt., 5c. MIXED

\section{Antirrhinum}

\section{(Snap Dragon)}

This old favorite is one of the most beautiful and useful border plants of our gardens. Its very graceful flowers are borne on long spikes and in the greatest diversity of colors. Our strains of Giant Snapdragons have been selected with the greatest care, and we know they are very superior. They bloom profusely the first season from seed, but will be much stronger the second year. Half hardy perennials of easiest culture. The immense spikes of enormous flowers are most brilliant and showy. 2 feet.

\section{GIANT QUEEN VICTORIA (New)}

Extra large, superb; pure white. Pkt., 10c.

Collection Giant Antirrhinums, 5 separate colors, 35c.

\section{GIANT-FLOWERING FINEST MIXED COLORS}

\section{(See Illustration)}

An elegant assortment of innumerable rich colors and shades, including all the named varieties offered by us. Pkt., 10c; 3 pkt3., $25 \mathrm{c} ; 1 / 4$ oz., 30c; oz.. \$1.00.

\section{DWARF MIXTURE}

Contains the very choicest colors, 12 inches. Pkt., 5c; 1/4 oz., 20c. TALL MIXTURE

The best colors. 2 feet. Pkt., 5c; 1/4 oz., 15c.

\section{ARISTOLOCHIA}

\section{(Dutchman's Pipe)}

A beautiful hardy climber. Leaves large and luxuriant; flowers brownish yeî́ow, in shape resembling a pipe. Pkt., 5c.

\section{AQUILEGIA}

\section{(Columbine)}

One of the most popular perennials, easiest of cultivation. Blooms profusely from May to August; very desirable for herbaceous borders and groups among shrubs. Moist soil preferable. Hardy perennial. Finest Mixed. Pkt., 5c.

\section{Ageratum}

A beautiful hardy annual of neat, bushy habit. The attractive feathery flowers borne in dense clusters Theful for bouquets. Very desirable for out

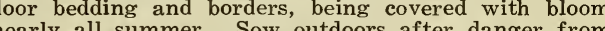
frost is over; or for earlier blooming start under glass and transplant. Cover the seed with one-eighth to one-fourth inch of fine soil firmly pressed down. Choice mixed, pkt.. 5c.

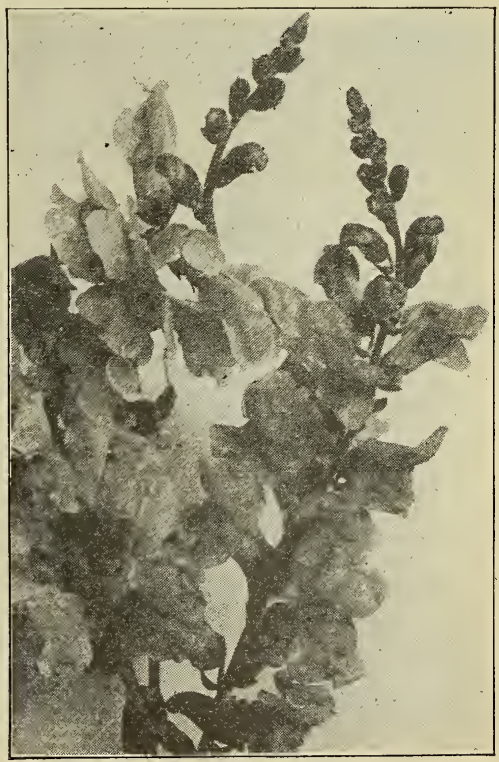

Antirrhinum 


\section{ASTER}

Of flowers grown from seed. few are more satisafctory than asters. They are easily grown in any good soil, in any location, and by anyone. They grow in open ground or in partial shade. They bloom at the time of the year when other flowers are scarce, and from July to frost they furnish a wealth of bloom. The seed can be planted either in the open ground or in a hot-bed or cold-frame, or the plants may be started in a box in the house. There is a big list of sorts, and the ones we have selected we think will please you.

\section{NEW AMERICAN BLANCHING}

The flowers are like beautiful chrysanthemums; large, very graceful, produced on long stems, well above the foliage; grand for cutting. Plants extra large and of strong growth; one plant will cover a space of $2 \frac{1}{2} \mathrm{ft}$. square. By far the most satisfactory grown. Mixed. Pkt., 10c.

\section{GIANT COMET}

Mixed. Fully equals in feathery form and fine coloring the regular strain of Comet Asters, but the plants are of stronger growth and produce larger flowers. With good cultivation the flowers will reach four inches across. and in form large size; the long stems approach in beauty fine chrysanthemums. Per pkt., 10c.

\section{GIANT BRANCHING COMET}

(See Illustration)

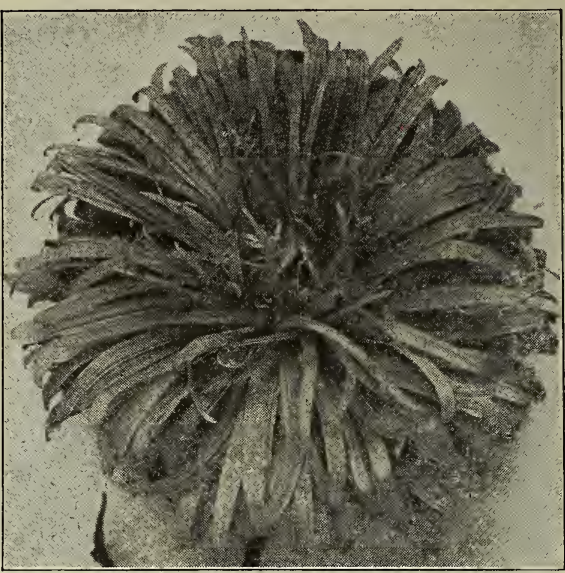

Giant Branching Comet

Among the most beautiful of all; 10 to 20 inches high: flowers often four to six inches across, with petals magnificently curled like a Chrysanthemum; sometimes bears 20 to 30 to a plant. Fine for cutting.

Mixed-Pkt., 10c. White-Pkt., 10c.

\section{TRIUMPH}

Choicest of the dwarf Asters; grows 7 to 8 inches high; each plant forming a bouquet in itself-thirty to forty flowers $2 \frac{1}{2}$ to 3 inches across. Many beautiful colors mixed. Pkt., 10c.

\section{VICTORIA}

Many attractive and snowy colors; flowers wide open four inches across; plants 15 to 18 inches high. Pkt., 10c.

\section{HOHENZOLLERN}

Flowers larger than Giant Comet; long twisted petals ; free bloomer, extra fine for cutting. Pkt., 10c.

\section{DAYBREAK}

Flowers large, very round and full; on long stems, delicate shell pink-suitable for cutting; begins blooming early and continues all summer. Pkt.. 10c. TRUFFAUT'S PERFECTION PEONY FLOWERED

One of the most perfect-and deservedly one of the most popular-of Asters. The plant forms large compact bushes about 18 inches high-which in the full flowering season are literally covered with large extremely double-perfect shaped flowers-with incurved petals-differing in this respect from the Victoria, which have outcurved petals, and are rivals of that sort for variety and purity of color. Pkt., 10c.

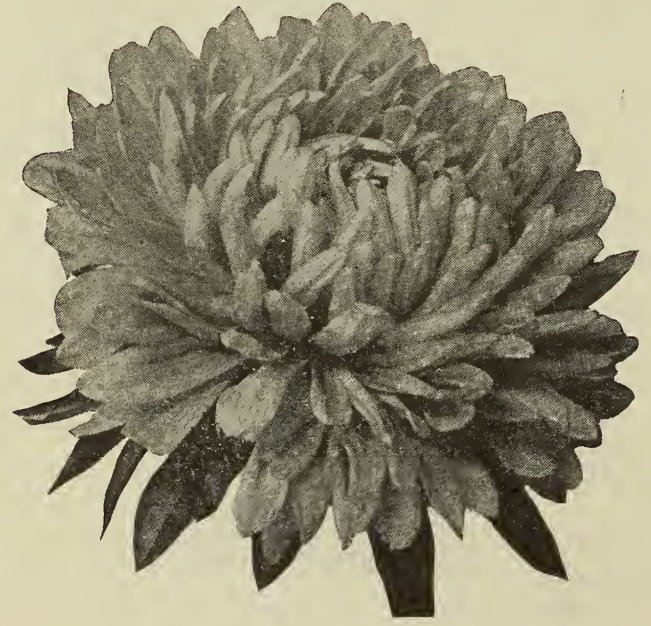

The earliest of all the Asters. Grows about nine inches high and very branching; the flowers are on long stems, making it valuable for cutting.

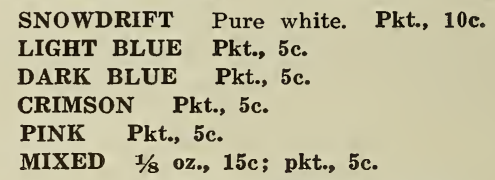

\section{GIANT HOHENZOLLERN}

This variety, while earlier than the late American Branching, is on a par with it in vigor and size of plant. Many consider it the grandest Aster ever introduced. The tall growing. branching plants have very long stalks, which bear flowers of mammoth size. The flowers, which may be cut with a stalk from twenty to twenty-four inches in length, measure from five to seven inches across, being densely double, fine curled, and bearing the greatest resemblance to a very large flowered Japanese Chrysanthemum. Unequalled as a cut flower and highly effective for tall beds and groups. Choice mixed, all colors. Pkt., 10c.

\section{EARLY-FLOWERING HOHENZOLLERN}

This beautiful Aster has the size of the later variety, but comes into bloom fully as early as Queen of the Market. It is a great advantage to have those Comet or Ostrich Plumed types so early. The flowers are very large, on long. wiry stems, and are fine for cutting. Choice mixed colors. Pkt., 10c.

\section{CREGO'S GIANT WHITE}

We consider this the finest and largest of all Comet Asters, bearing immense fluffy flowers five inches and over in diameter, as fine as any Chrysanthemum, and when cut keep in good condition longer than any other of this type. Pkt., 10c.

\section{CREGO'S GIANT PINK}

Identical in every way to the white offered and described above, except in color, which is a beautiful shell-pink. Pkt., 10c.

\section{VIOLET KING}

Similar in habit and time of flowering to the late flowering American Branching sorts, and of the same strong, free-branching growth, with very double, slightly quilled flowers of pleasing soft shade of violet. Pkt., 10c. 


\title{
Balloon Vine
}

\author{
(See Illustration)
}

Ornamental climbing plant, remarkable for an inflated memberaneous capsule, from which it derives its name. Pkt., 5c.

\section{Brachycome}

\section{SWAN RIVER DAISY}

Produce an abundance of daisy-like flowers, about 1 foot high. Fine for edgings, beds or rustic baskets. Pkt., 5c.

\section{Balsams (Lady Slipper)}

Beautiful half-hardy annuals, from $1 \frac{1}{2}$ to 2 feet in height. Sow the seed early in frames and transplant to a well enriched border. IMPROVED CAMELIA-FLOWERED

Finest mixed. Flowers very large and extra double. Pkt., 5IMPROVED CAMELIA-FLOWERED WHITE PERFECTION

Pure white, with large, very finely formed double flowers. The plant, with its stems thickly crowded with snow-white blossoms, procices a magnificent effect. Pkt., 5c.

Finest mixed. Pkt., 5c. DWARF SPOTTED

Very fine. Mixed. Pkt., 5c.

\section{Celosia (or Coxcomb)}

Free blooming, graceful plants, growing best in rather light soil, not too rich; grown in pots they are fine for the greenhouse or con servatory. Half-hardy annuals.

\section{DWARF FEATHERED MIXED}

Brilliant shades of crimson, scarlet, fiery red, and golden yellow. Pkt., 5c.

\section{TRIUMPH OF THE EXPOSITION} (See Illustration)

About two feet high. of branching habit; each stem is crowned with a magnificent feathery plume of brilliant red. Pkt., 5c.

\section{Canna}

\section{(Indian Shot)}

With foliage of tropical luxuriance; this plant is particularly suitable for forming groups on lawns or placed as backgrounds for dwarfer growing plants. Half-hardy perennial. Finest mixed. Pkt., 5c.

\section{Centaurea}

\section{BACHELOR'S BUTTON or CENTAUREA CYANIS}

A showy, hardy annual, succeeding well in any soil and bearing a profusion of flowers in shades of pink, blue and purple. Pkt., 5c.

\section{CENTAUREA MARGARET}

Large, fragrant flowers; produced on long, stiff stems. They are fine for cutting and decoration. Pkt., 5c.

\section{Calliopsis or Coreopsis}

One of the most showy of all annuals, the colors being very striking. Pkt., 5c.

\section{COREOPSIS}

(Mixed Varieties)

Yellow and brown and velvety brown. Pkt., 5c. COREOPSIS LANCEOLATA

Very free blooming and lasting. Unequaled for cutting. Pkt., 5c.

\section{Chrysanthemums}

Handsome, hardy annuals, producing quantities of large flowers of striking colors.

SINGLE OR "PAINTED DAISY" VARIETIES

Pkt., 5c.

$$
\text { (Mixed) }
$$

\section{DOUBLE YELLOW}

Flowers very double, globe-shaped, extremely double. Pkt.. 5c.

\section{DOUBLE FRINGED}

$$
\text { (Mixed) }
$$

Flowers very double, with exquisitely fringed petals, in great diversity of colors, from white and yellow to blood-red purple. Pkt., 5c.

\section{Cacalia}

\section{(A Tassel Flower)}

A popular annual and hardy. Flowers tassel shaped; yellow and scarlet. Grows $1 \frac{1}{2}$ feet. Mixed colors Pkt., 5c.

\section{Candytuft}

\section{(See Illustration)}

A most popular hardy annual; almost equally so as Sweet Alyssum; of easy culture; very good for bouquet making. Cultivate as Asters. Choice mixed. Pkt., 5c.

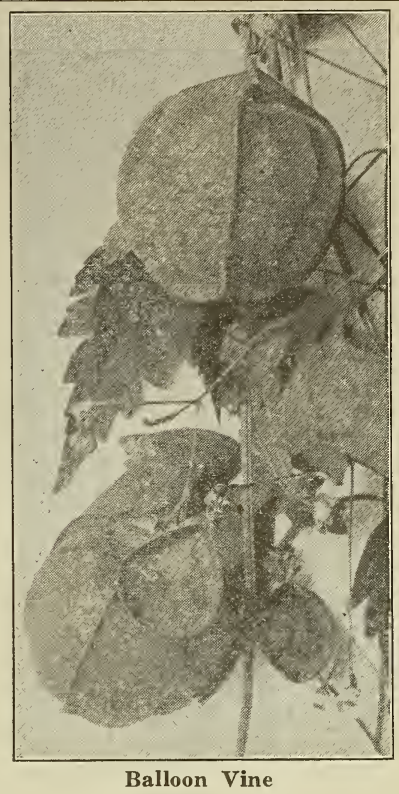

\section{Carnation}

DOUBLE PERPETUAL FLOWERED

Fine for winter blooming. From the choicest double flowers. Pkt., 25c.

EXTRA CHOICE DOUBLE MIXED

A large portion of this seed will produce double flowers. Pkt., 20c.

\section{DOUBLE MIXED}

All shades and colors. Pkt., 10c.

MARGUERITE

With ordinary care will be in full bloom in four months after sowing the seed, flowering in profusion until checked by frost. The flowers range through many shades. Mixed. Pkt., 5c.

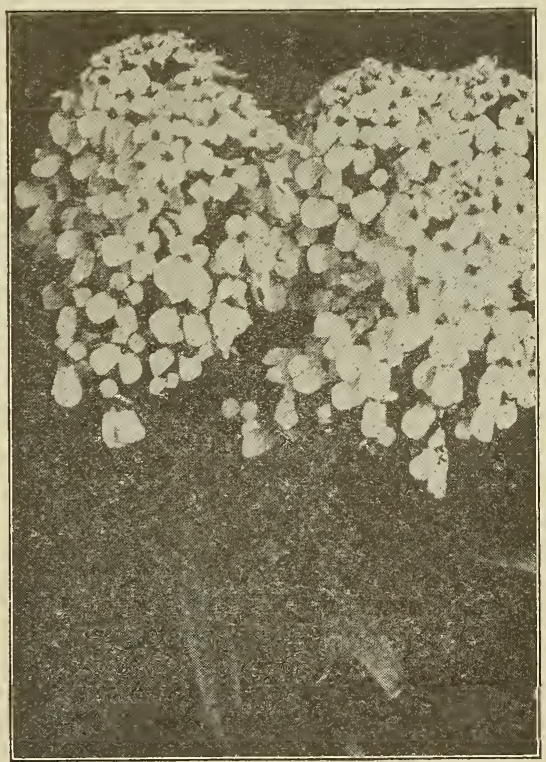




\section{Canterbury}

\section{CAMPANULA}

Imposing hardy plants about 3 feet in height; profusely covered with large bell-shaped flowers-extremely showy and valuable for cutting. Half-hardy annuals. Double mixed-Pkt., 5c. Single mixed-Pkt., 5c.

\section{Canary-Bird Flower}

There is no more desirable climbing plant in cultivation than this. It is of rapid growth, and produces an abundance of yellow fringed flowers. Half-hardy annual, $10 \mathrm{ft}$. Pkt., 5c.

\section{Cosmos}

\section{EARLY FLOWERING}

Blooms steadily from June until frost. Flowers borne in masses all over the plant which is about four feet high. Pkt., 5c.

Late variety. Mixed. Pkt., 5c.

\section{Cypress Vine}

IPOMOEA QUAMOCLIT

This is a beautiful, rapid-growing annual climber, with delicate dark green finely cut fern-like foliage and masses of most brilliant and graceful star-shaped flowers. The two shades, white and scarlet, are very striking. Planted by the side of a veranda, tree or stake, and trained properly, nothing is prettier.

Pure White-Pkt., 5c.

Bright Scarlet-Pkt., 5.

Finest Mixed-A mixture of Pure White and Bright Scarlet. Pkt., 5c; $1 / 2$ oz., 15c.

\section{Datura (Trumpet Flower)}

Very attractive, bushy plants of easy growth, that during the whole season are covered with elegant, fragrant, trumpetshaped flowers. Hardy annual. 3 feet.

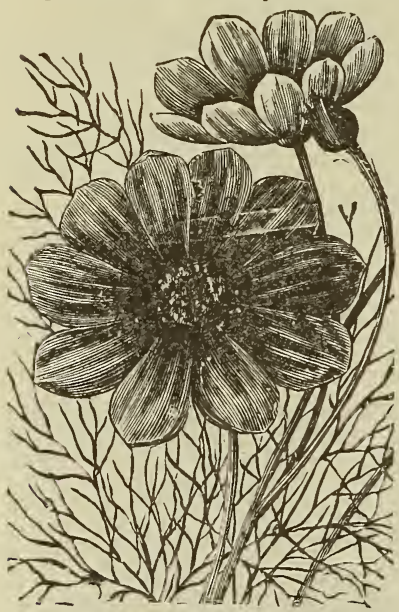

Cosmos

\section{feet.}

CORNUCOPIA (Horn of Plenty)

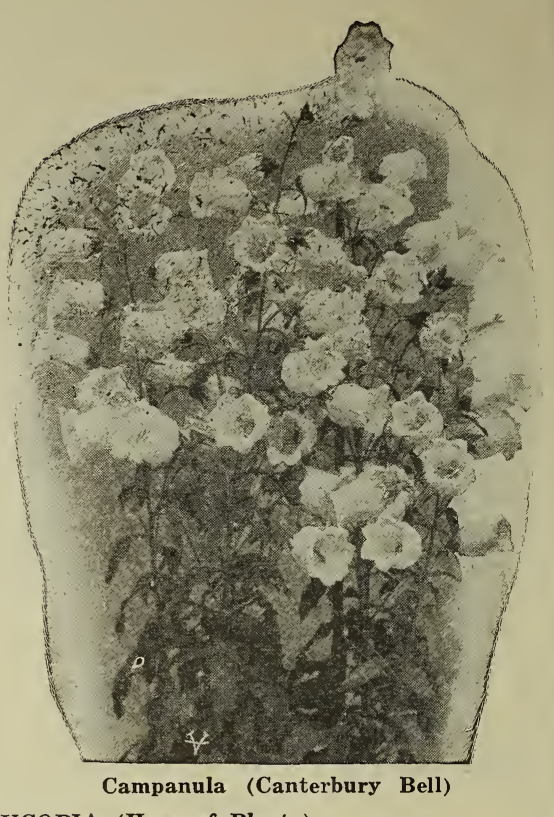

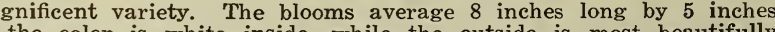
marbled with royal purple. Pkt.. 5c; $1 / 4$ oz., 20 c.

\section{FINEST DOUBLE MIXED}

A very choice assortment of all the best colors and varieties of this effective annual. Pkt., 5c.

\section{Dahlia}

Sow the seeds early in pots or under glass, and transplant to strong, deep, rich soil, and plants will bloom the first season.

DAHLIA. Single Varieties.

Splendid mixture. Handsome bedding plants, and extensively used for cutting. Pkt., 5c.

DAHLIA. Double Mixed.

Seeds saved from the fine named sorts. Pkt., 10c.

\section{Double Daisy (Bellis Perennis)}

Charming plants for edging and dwarf beds, blooming the first year from seed. Thrive well in shady place.

\section{DAISY, SNOWBALL}

Large flowered, pure white, and extremely double, with very long stems, making them valuable for cutting. Pkt., 5c.

DAISY, "LONGFELLOW"

Flowers of unusual size, a dark rose color. Pkt., 5c.

Mixed. Pkt., 5c.

\section{DAISY, DOUBLE}

\section{Delphinium (Perennial Larkspur)}

Flowers remarkable for their great beauty, diversicy of shades, and striking appearance. Desirable for mixed borders. If sown early will blossom first year from seed.

\section{DELPHINIUM FORMOSUM}

(See Illustration)

Our flowers were two inches in diameter by actual measurement, brilliant azure blue in color. Spikes 8 to 10 inches in length. Pkt., 5c.

\section{DELPHINIUM ELATUM}

(Bee Larkspur)

Blue. 2 foot. Pkt., 5c.

DELPHINIUM HYBRIDUM

Fine mixed, splendid. Pkt., 5c.

\section{Dianthus}

(Chinese Double Pinks)

The Dianthus are quite similar to Carnations and among the most beautiful and popular flowers in cultivation; will flower both first and second seasons; unsurpassed in brilliancy of color and profusion of bloom. Sow seed in house in April; out of doors in May. Hardy annual. Mixed, Pkt., 5c.

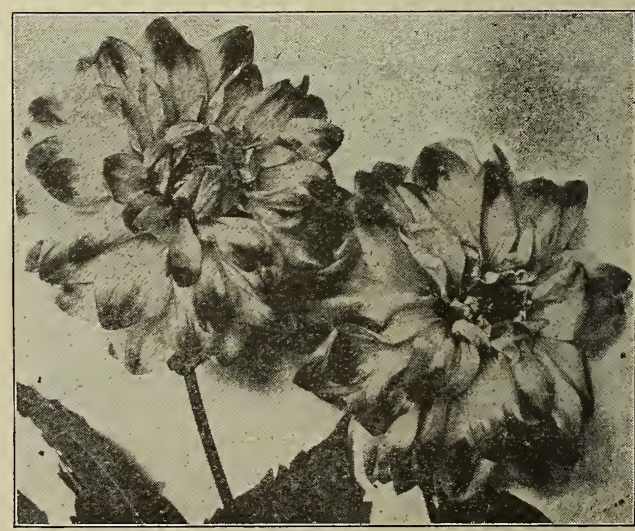

Showy Dahlias 


\section{Four O'Glock (Marvel of Peru)}

A handsome, free-flowering half-hardy perennial; blooming the first season from seed; the flowers, which are produced in clusters, open in the afternoon and wither the next morning. They can be kept like Dahlias. Our mixture contains a fine variety of colors. Oz., 10c: 1/4 lb., 20c; pkt., 5c.

\section{Foxglove (Digitalis)}

One of the most widely known and popular hardy plants. Its ease of cultivation, the mammoth spikes of splendidly colored flowers make them very desirable for use in borders or as backgrounds for lower growing plants. Spikes grow to a height of three to five feet. Hardy biennials.

Pkt., 5c.

\section{FINEST MIXED GLOXINOIDES}

\section{Eschscholzia \\ (CALIFORNIA POPPY)}

Many brilliant colors; flowers large saucer-shaped; blooming all summer. Mixed, Pkt,, 5c.

\section{Forget-me-not}

(MYSOTIS)

These charming little favorites succeed best in damp, shady situations, but will thrive in almost any soil. The Alpestris varieties also bloom well as pot-piants during winter if kept in a cool room. Pkt., 5c.

\section{Gomphrena}

\section{(GLOVE AMARANTH)}

Handsome; everlasting, with showy flowers. The flowers should be cut in the summer and preserved for winter bouquets. Half-hardy annuals. Mixed, Pkt., 5c.

\section{GOURDS}

Very ornamental, fine and curious. Very valuable for covering old trees, fences, etc. Ornamental mixed. Pkt., 5c.

\section{Heliotrope}

Grows twelve to eighteen inches high, bearing graceful heads of purple, lilac and white flowrs. Equally good for potting in winter or bedding in summer. Flowers deliciously fragrant. Mixed, Pkt., 5c.

\section{Hibiscus}

(CRIMSON EYE) (See Illustration)

Vigorous grower; dark red stems; three feet high; pure white flowers six to seven inches in diameter, each with a deep velvety crimson spot in the center. Plants perfectly hardy, blooming first year; when established will produce several hundred flowers in season. Pkt., 5c.

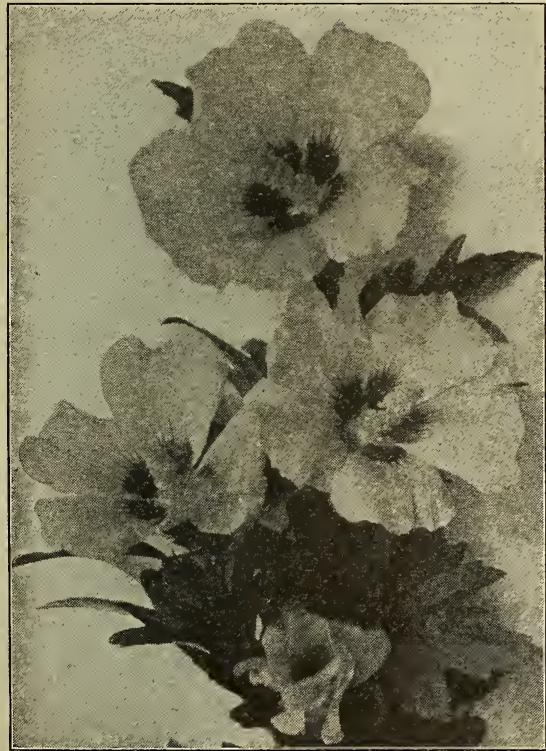

Crimson Eye

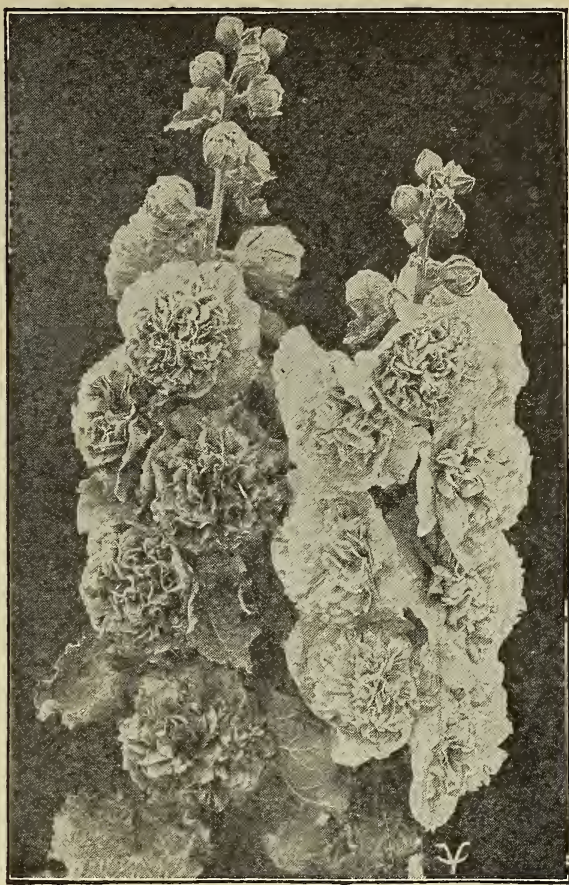

Hollyhocks-Double Mixed

\section{Hyacinth Bean}

A rapid growing annual climber, about 10 feet high. They bloom freely in clusters, which are followed by ornamental seed pods. Sow seed in April or May. White and purple, mixed, $1 / 2$ oz., 15c; pkt.. 5c.

\section{Hollyhock}

A most splendid plant of stately appearance; flowers large and double as roses of every shade and color. Sow seeds out of doors where they are to bloom. Hardy perennials. Finest Double Mixed. Pkt., 5c.

\section{Ipomea}

Tender annuals of rapid growth, with beautiful and varied flowers; for covering old walls, trellises, arbors or stumps of trees, 15 to 20 feet.

\section{GRANDIFLORA (Moonflower)}

One of the most showy of the annual climbers. A rapid growing vine, easily reaching a height of 25 to 30 feet. At night and during dull days the plants are covered with large, pure white, fragrant flowers, five to six inches in diameter. Pkt., 10c.

\section{Ipomea Setosa}

\section{(BRAZILIAN MORNING GLORY)}

A summer climber, making a dense shade. The vine is highly ornamental. Flower rose colored; three to four inches in diameter. Pkt., 5c.

\section{Larkspurs (Annual Delphinium)}

These popular garden flowers have been greatly improved of late in color and size of blooms and habit of plants. Below we offer the best of the newer varieties. Hardy annual.

\section{DOUBLE DWARF ROCKET}

A most choice mixture of varieties, that grow about 1 foot in height. Pkt.. 5c; 1/2 oz., 15c.

\section{DOUBLE TALL ROCKET}

This well-known mixture embraces the very choicest colors in the taller growing sorts. Pkt., 5c; 1/2 oz., 15c. 


\section{Kochia Tricophylla SUMMER CYPRESS \\ (See Illustration)}

This splendid annual plant grows very quickly from seed sown in the open ground as soon as the weather permits in spring. The plants always make attractive globe-shaped bushes, as large sometimes as 3 feet high and 2 feet across in one season. (See illustration from photo taken in our trial grounds.) Leaves slender and of a light pea-green color until September, when they turn to carmine and blood-red; at the same times the ends of the shoots are thickly set with small bright scarlet flowers and produce a very striking effect. Pkt., $10 \mathrm{c} ; 1 / 4 \mathrm{oz} ., 25 \mathrm{c}$.

\section{Marigold}

Old favorite of easy culture, with various colored beautiful double flowers and fine foliage; very effective for groups and masses. Hardy annuals.

\section{AFRICAN PRIDE OF THE GARDEN}

A fine early variety, of regular, compact habit. Color rich, golden yellow, 2 feet. Pkt., 5c.

\section{DOUBLE AFRICAN \\ (See Illustration)}

Tall, mixed orange and yellow shades, 2 ft. Pkt., 5c. DOUBLE AND SINGLE FRENCH

Finely cut foliage. Dwarf mixed colors. Pkt., 5c.

\section{Morning Glories \\ JAPANESE GIANT}

A class of climbers making a growth of 20 to 30 feet quite early in the season. Their large flowers are striped, spotted and margined in all shades from white to the deepest red, blue and purple. Many are fluted and fringed. Sow the seeds early in a warm sunny place. Choice mixed. Oz., 20c; pkt., 5c.

\section{LARGE FLOWERING ROCHESTER}

Vines istrong, growing 12 to 20 feet high, with magnificent foliage. Flowers 4 to 5 inches across, deep violet blue in the throat, blending out to an 2zure blue, bordered with a white band around the edge. Oz., 60c; pkt., 10c.

\section{MORNING GLORY}

(Convolvulus Major)

The well known old fashioned Morning Glories. Splendid climbing plants. Of rapid growth and profuse bloom. Oz., 10c; pkt., 5c.

\section{Mignonette (Reseda)}

Without Migmonette in our gardens, something indeed would be missing. Its large, deliciously fragrant spikes of bloom are everyone's admiration. Make successive sowings in the garden, from April to July, for continuous bloom until frost; and if the plants are thinned out to six inches apart, and the tops pinched off when about two inches high, stronger plants, with large spikes of elegant bloom, will be the result. Height, 1 to 2 feet, according to the variety.

Pkt., 5c.

$$
\text { MIGNONETTES (Mixed) }
$$

\section{Job's Tears}

Curious ornamental grass with broad, corn-like leaves and lustrus slate colored seeds used for beads. Valuable for -winter bouquets with everlasting flowers. Plant outdoors early in the spring in hills three feet apart, four or five seeds in a hill, and cover half an inch deep. Hardy annual; three feet high. Pkt., 5c; oz., 10c; 1/4 lb., 25c; 1 lb., $8 \mathrm{cc}$.

\section{Lantana}

The plants form small shrubs, producing in late summer and autumn an abundance of heliotrope-like clusters of single, fragrant flowers that change color. Succeeded by green berries that turn to a deep blue. Start under glass and transplant when danger of frost is over. May also be grown in pots. Tender perennial; about two feet high. Pkt., 5c.

\section{Momordica Balsamina}

(BALSAM APPLE)

An annual climber, with yellow blossoms and beautiful foliage. The fruit when ripe bursts suddenly open, scattering its seed, and showing a brilliant carmine interior. Fine for trellises, fences, stumps, etc.; half-hardy annual; 10 feet. .Pkt., 5c.

\section{Nicotiana}

A handsome genus of garden plants of the tobacco family, which are noted for the freedom and fragrance of their bloom. Half-hardy annuals, 3 feet Flowers white, salver shaped, having long, tubular corollas, and are of exquisite fragrance. Deserves a place in every garden. Pkt., 5c.

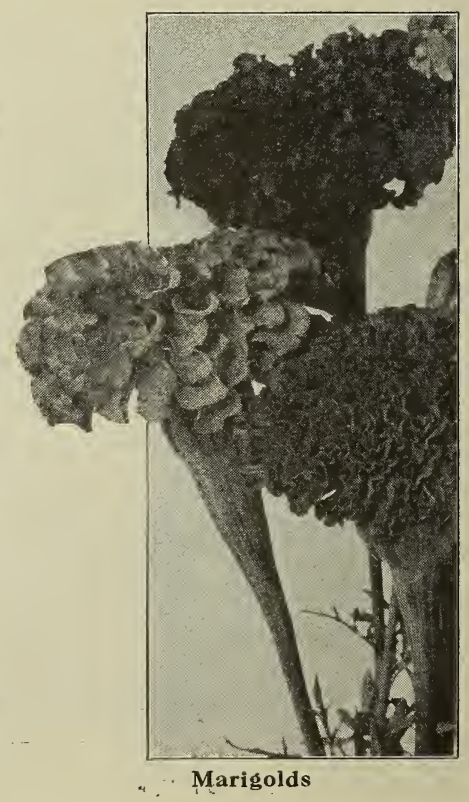




\section{NASTURTIUIIS}

Nasturtiums are hardy annuals of easy cultivation and flower best where the soil is not too rich. The new hybrids include various shades of rose, salmon, red, pale yellow, etc., either self-colored or spotted mottled stripes and margined. For covering fences, trellises, arbors, piazzas, trailing from vases, over rockwork, for bedding, etc., nothing can equal the gorgeous effect produced by their marvelous wealth of bloom; borne in uninterrupted splendor from early summer until cut down by frost. The seeds picked green and pickled in vinegar have a piquant appetizing flavor that is a valuable addition to relishes or pickles. Dwarf Mixed, Pt., 5c*..Tall Mixed, Pkt., 5c.

\section{LOBB'S CLIMBING NASTURTIUMS}

(Tropeolum Lobbinum)

They are as easily grown as the common Tall Nasturtium, which they far surpass.

Intense scarlet-red, dark foliage.

BRILLIANT

CRYSTAL PALACE

Very bright, orange, salmon flowers. Pkt., 5c. SPITFIRE

Bright, fiery scarlet. LOBBS CLIMBING MIXED

Lobbianum varieties. A wide range of colors and shades. Pkt. 5c; oz., 10 c.

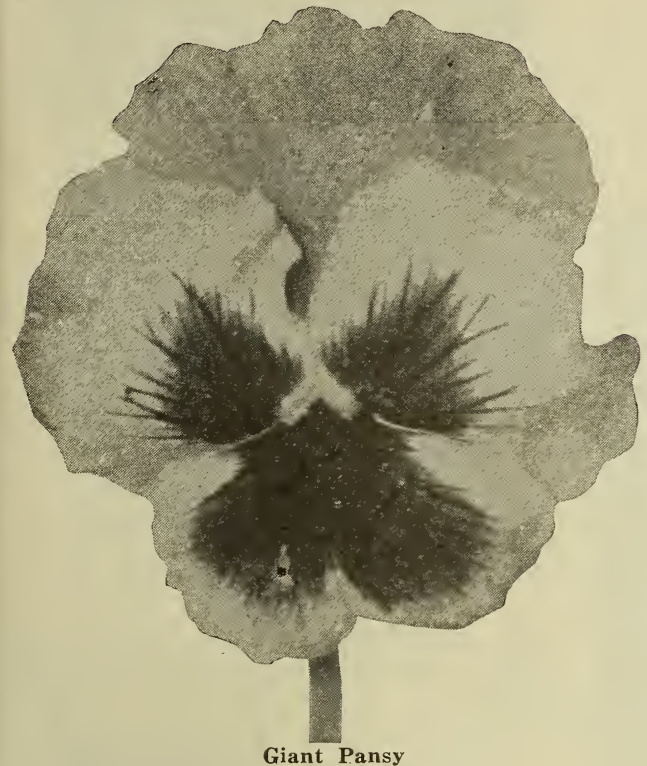

Jet black. Pkt., 10c.

\section{BLACK}

\section{BRIDESMAID}

Flowers very large and of fine form. Its ground color is a rosy white, and most strikingly sets off the dark blotches of the center. Pkt., 10c.

\section{RUBY}

Superb red. Pkt., 10c.

One packet each, 7 distinct Giants, $50 \mathrm{c}$.

\section{SUPERB GIANT MIXED}

(See Illustration)

An extra fine mixture of Giant Pansies, including all of the above together with Odier, Cassiers, Bugnot and Trimardeau sections. 3 pkts., 25c; $1 / 8$ oz., 75c; pkt., 10c.

\section{ORCHIDEAEFLORA MIXED}

New, very interesting type; flowers resemble an orchid in their wonderful and quaint shape as well as in the charming shadings. Mixed colors. Pkt, 20c.

\section{CHOICE MIXED}

This mixture is specially prepared for the most critical pansy lovers and the florists, who require the greatest variety of colors, as well as flowers of the very largest type. Pkt., 5c.

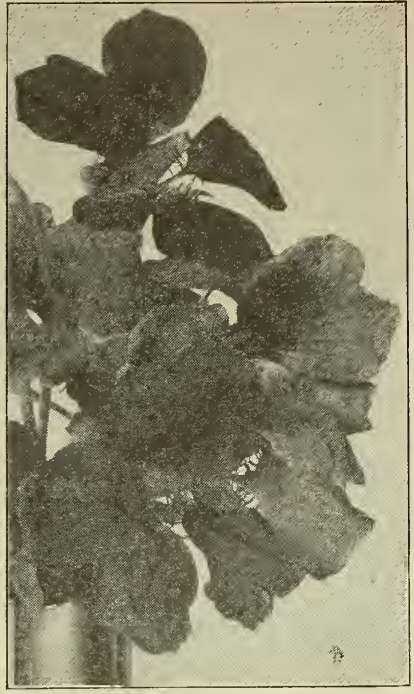

Nasturtiums

PANSIES

The flowers are much larger during the cool weather than through the summer. The seed may be sown in the hot bed, in boxes in the house or in the open ground. if sown in the spring, get them in early so they will come into bloom before the hot weather comes on. Sown later and slightly protected during the winter with leaves, they will make strong blooming plants for spring.

\section{Superb Giant Pansies}

These have been selected and with a view to largest sized flowers of thick velvety texture and most distinct colors, and have been brought as near perfection as possible.

Light blue with white center. Pkt., 10c.

\section{BEACONSFIELD}

Deep purple violet, shading to lavender and white. Pkt., 10c.

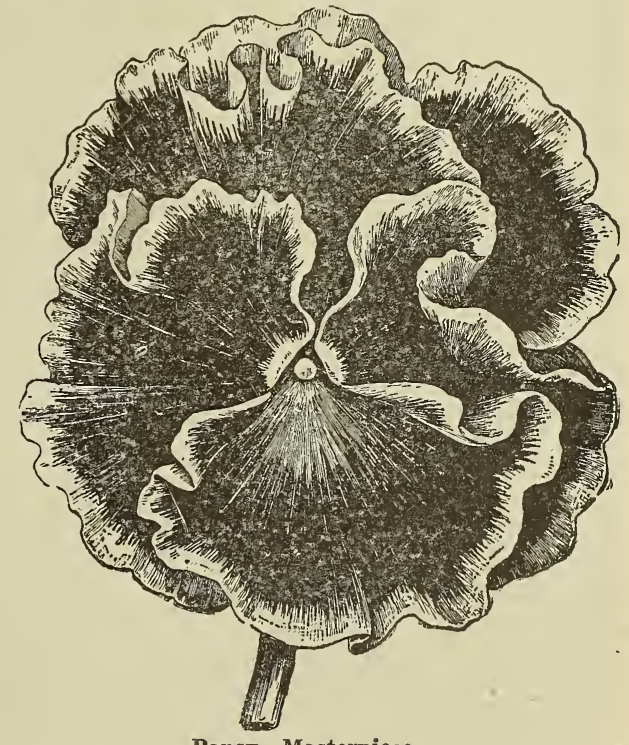

Pansy-Masterpiece 


\section{PETUNIA}

Favorite plant, succeeding well in any rich soil. For the brilliancy and variety of their colors, abundance of flowers and the long duration of their blooming period, they are indispensable in any garden and are also highly prized for growing in pots for the greenhouse or sitting-room. Hardy annuals. The seed may be sown in the ground after the danger of frost is past.

GIANT RUFFLED

An improved strain of California Petunias, flowers often measuring three to four inches across. Its color comprises all shades from purest white through rose, pink, carmine and purple. Most of the flowers are brilliantly marked, veined and fringed. Altogether one of the most effective strain of this popular flower. Pkt., 25c.

\section{CALIFORNIA GIANT}

Flowers very large, in great variety of colors and markings, with deep yellow throats. Pkt., 15c.

\section{PURE WHITE}

Desirable for cemetery beds or where large masses of white are wanted; grows twelve to fifteen inches high. Pkt., 5c. STRIPED AND BLOTCHED

A good strain of the small-flowering type; beautifully striped and blotched; fine for massing. Pkt., 5c.

$$
\text { FINE MIXÉD }
$$

An excellent variety of markings including white stripes and shades of rose, red and purple. Pkt., 5c.

\section{POPPIES}

POPPY (Papaver)

These well known hardy annuals and perennials flower in great profusion throughout the summer. Both the single and double varieties are very desirable for bedding and borders. The flowers are remarkable for their large size, delicacy of tissue and wide range of bright dazzling colors. As early in spring as ground can be worked sow seed where flowers are to bloom as the annual varieties do not bear transplanting.

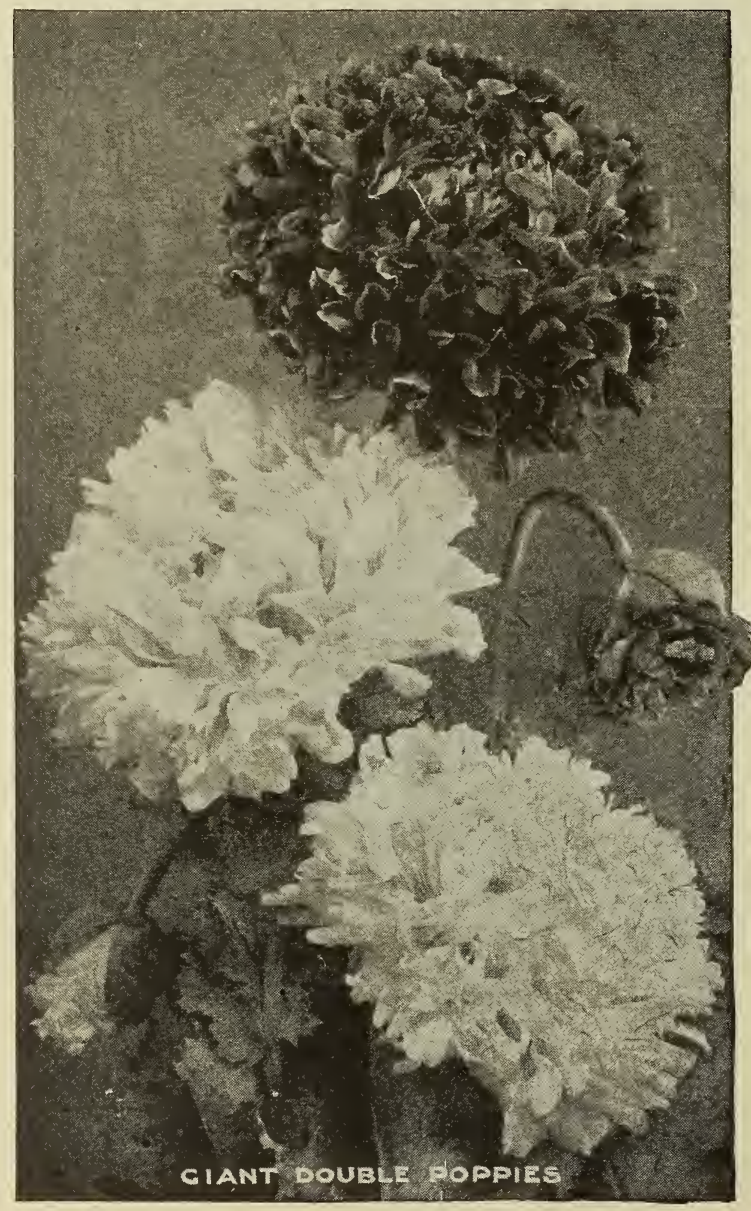

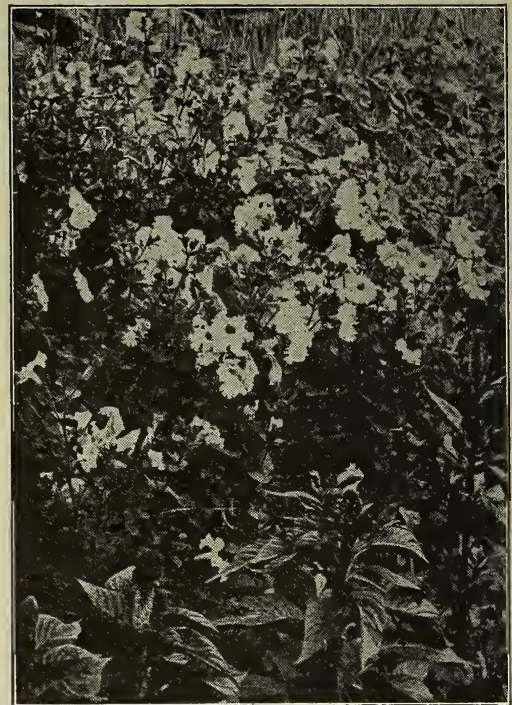

\section{Annual Varieties}

\section{SHIRLEY}

A magnificent variety, producing through a long season large single flowers of charmingly delicate colors, ranging from pure white through shades of pink and rose to the brightest scarlet and carmine-red. If cut before the blooms are fully expanded, they will keep fresh in water for several days. Hardy annual, about twenty inches high. Oz., 35c; pkt., 5c.

\section{CARNATION, DOUBLE MIXED}

Large showy-double fringed flowers of fringed flowers of various colors; hardy annual; about two feet high. Oz., 15c; pkt., 5c.

\section{GIANT DOUBLE CHOICE MIXED}

Very large, double poppies in a variety of colors. Some petals quite broad, others finely fringed. About two feet high. Oz., 20c; pkt., 5c.

\section{Perennial Varieties}

Perennial poppies do best in rows one and one-half feet apart and one foot apart in the row. Seed may be sown outdoors either in spring or fall.

\section{ORIENTALE}

Very large single gorgeous scarlet blossoms; base of petals bluish black. One of the most showy garden perennials; about two feet high. Pkt., 5c.

\section{Portulaca}

\section{PORTULACA or ROSE MOSS}

Brilliant dwarf annuals only six inches high luxuriating in warm situations and blooming profusely from early summer until autumn. For low beds and masses of color from spring until frost they are indispensable; colors range through innumerable shades of red, yellow, pink, striped, white, etc.

\section{SINGLE MIXED}

Pkt., 5c; $1 / 4$ oz., 25c. DOUBLE MIXED

Pkt., 10c; 1-16 oz., 25c. 


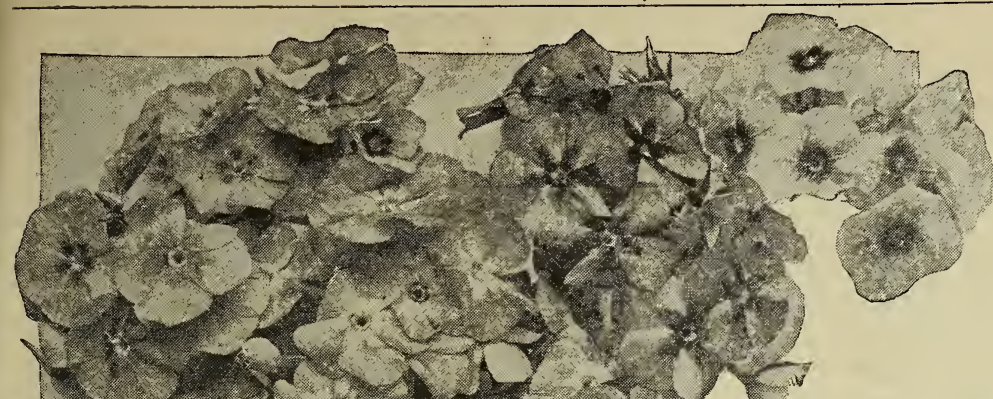

\section{PHLOX}

This annual Phlox is a native of Texas, where it is called "Texan Pride." It occupies a first place as a garden annual, being one of the most brilliant and at the same time one of the easiest and most satisfactory plants, which can readily be grown from seed. It will grow and thrive in any kind of soil if given a sunny position, but prefers a light, rich

loam. Seed may be sown in the open ground any time after danger from frost is past, and in a few weeks they are a sheet of bloom, remaining so until frost. They may be used in a variety of ways but is shown to best advantage when grown in masses. in beds or borders.

\section{PHLOX DRUMMONDI}

Mixed colors. Pkt., 5c.

\section{CHOICE LARGE-FLOWERING MIXED}

This is a magnificent class of these splendid annuals. Flowers are large and brilliant in color. Pkt., 5c.

\section{STAR PHLOX}

Long, pointed petals, which give the flowers a star-like appearance; plants grow compast and dwarf. Pkt., 5c.

\section{Hardy Perennial Phlox}

Hardy herbaceous perennial and quite distinct from the varieties of Phlox Drummondi offered above, which are annuals. For the best results should be sown as soon as frost is out of the ground in spring or as soon as gathered in the autumn. Mixed colors. Pkt., 5c.

\section{Phlox Drummondi}

Grandiflora

\section{RICINUS}

(CASTOR OIL PLANT)

A highly ornamental, half-hardy annual, growing from 4 to 6 feet high, presenting quite a tropical appearance. Select warm, dry soil and plant six feet apart.

\section{RICINUS ZANZIBARIENSIS \\ (Zanzibar Castor Bean)}

Very showy, with gigantic leaves which range from brilliant coppery-bronze to light and dark green; the ribs also are of bright colors, making a beautiful contrast with the leaves. Pkt., 5c.

\section{SALVIA}

Among the most desirable and showy bedding plants grown. Brilliant flowers are grown in profusion from early spring until frost. Excellent for cutting. Seeds sown early in the house will produce better plants than from cuttings. Height about three feet. Half-hardy annuals.

\section{ZURICH}

A dwarf variety, with long spikes of brilliant scarlet flowers. It is free blooming, and a desirable addition. Pkt., 10c.

\section{SPLENDENS}

One of the most gorgeous of annuals, blooming throughout the summer and fall. The plants grow from one and one-half to three feet in height and are completely covered with showy sprays of bright scarlet flowers. Pkt., 10c.

\section{DROOPING SPIKES}

This large flowering variety has three times the flowering capacity on each spike of the ordinary Salvia Splendens. The flowers are produced in great numbers causing the spikes to droop by their own weight. Pkt., 10c.

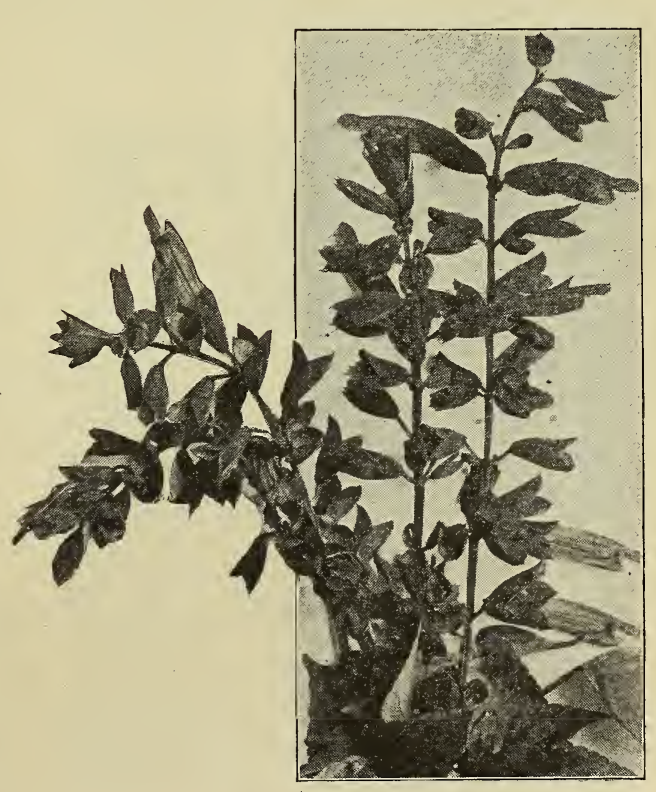

Salvia 


\title{
SALPIGLOSSIS GRANDIFLORA
}

Flowers 2 to 3 inches in diameter, vividly marked, spotted and striped on ground colors of deep blue, rose, violet, yellow, reddish bronze, purple, etc. In rich coloring they vie with Orchids in mixed colors. Pkt.. 5c.

\section{SIIILAX}

No climbing plant surpasses this in beautiy and grace of foliage. Extensively used for bouquet and floral decorations. Pkt., 5c.

\section{STOCKS}

\section{(STOCKS GILLY FLOWERS)}

Stocks leave little to be desired in general usefulness of a flower of its type. They are very easy to grow and have splendid foliage and beautiful fragrant blossoms, in a wide range of colors, that are produced in lavish profusion, throughout a long season. A very useful bedding and pot plant. Sow in hot beds or boxes during March and April, transplanting to boxes or pots, when weather is suitable transplant to open ground, about one foot apart, for early flowers. Sow in open ground in May. Plants may be lifted in fall and potted up for winter blooming indoors.

\section{LARGE FLOWERING TEN WEEKS}

This favorite half-hardy summer blooming annual has deliciously fragrant flowers and is very desirable for cutting. Pkt., 10c.

\section{DOUBLE GERMAN TEN WEEKS}

Shades of white, red, purple, lavender and maroon. Pkt., 5c.

\section{SCABIOSA (Morning Bride)}

Firm favorites with many of our customers. Seed can be sown any time in the spring after danger of frost is past. They grow about $2 \frac{1}{2}$ feet high, and come into bloom early in July, and continue without interruption until hard frost. The beautiful flowers in exquisite shades are borne on long stems, and when cut keep in perfect condition for the best part of a week. They make effective borders or beds, and no garden is complete without Scabiosas, especially where flowers are wanted for cutting. Choice mixed colors. Pkt., 5c.

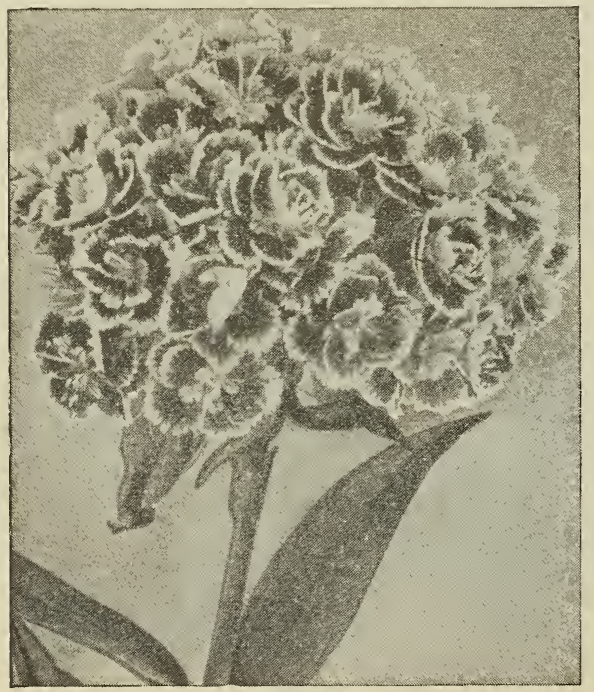

\section{SCHIZANTHUS}

\author{
(Butterfly Flower or Poor Man's Orchid)
}

An attractive hardy Annual growing about 20 inches high which is of neat, compact growth with finely cut foliage. The plant bears very attractive flowers ranging in colors from white to purple and are shaded from their edges to throats with darker colors. Flowers resemble somewhat the butterfly and are borne in clusters or spikes.

Seed can be sown outdoors after danger of frost, or started earlier indoors and transplanted. They also make very attractive pot plants. Finest Mixed Colors, Pkt.. 5c.

\section{SWEET WILLIAII}

\section{(Dianthus Barbatus)}

For a display in the garden, the Sweet William is unsurpassed. The seed can be planted very early in the spring, in open ground, and will blossom the following summer; or it may be sown in August, and will make fine blooming plants for spring. Hardy perennial. One and one-half feet in height.

\section{DOUBLE MIXED}

From a splendid selection of double flowers. Pkt., 10c. SINGLE MIXED 


\section{SUNFLOWER}

DOUBLE CHRYSANTHEMUM FLOWERED

A tall plant, growing seven feet high and blooming profusely all summer. Flowers are double, large, round, golden yellow, and resemble chrysanthemums. Pkt., 5c.

\section{GLOBOSUS FISTULOSUS}

Produces very large, exceedingly double flowers of bright yellcw color. Plants about five feet high. Pkt., 5c.

\section{LARGE RUSSIAN}

A strong growing, single variety, about six feet high. The stalks are sometimes used for fuel. Pkt., 5c; oz., 10c; 1/4 1b., OUR EXTRA CHOICE MIXTURE

Contains many kinds and colors of splendid, easily grown flowers, and has become very popular wherever known. Large ckt, 5c; oz., 15 c.

\section{MAMMOTH VERBENAS}

If it were possible, it would seem to us that Verbenas are becoming more popular every year. The plants thrive in any good garden soil, and if grown from seed are much more vigorous than if started frcm cuttings. Verbenas will flower perfectly from seeds started early in the house in boxes or pots; or you may plant the seeds directly in the garden beds when the warm weather of May arrives. Height 1 to $1 \frac{1 / 2}{2}$ feet.

$$
\text { FINE MIXED }
$$

wide range of colors, shades and stripes, usually running from pure white to deep purnlo $\mathrm{Cz}$., 75c; pkt. 5c.

\section{EXTRA CHIICE MIXED}

Includes all the best types and a wide range of splendid colors. Oz., \$1.25; pkt., $10 \mathrm{c}$.

\section{MAMMOTH MIXED}

Embraces a wide range of the most beautiful colors, the clusters being of largest size. Oz, $\$ 1.75$; pkt., 15c.

\section{VIOLETS}

\section{(Viola Odorata)}

Sweet-scented Violets are easily grown from seeds; and if you can plant them in a cool and moist situation, so much the better. All varieties are of great beauty. Pkt., 5c.

\section{Wild Cucumber}

(ECHINOCYSTIS)

A rapid-growing annual climber. Has beautiful leaf and pretty. fragrant white flowers. Pkt., 5c: $1 / 2$ oz., 10c; oz., 15c.

\section{Wallflower}

Well-known and deliciously fragrant half-hardy biennials ; the large spikes of bloom are of most beautiful colors. Height $11 /$ feet.

Large-Flowering Single Mixed.-Pkt., 5c.

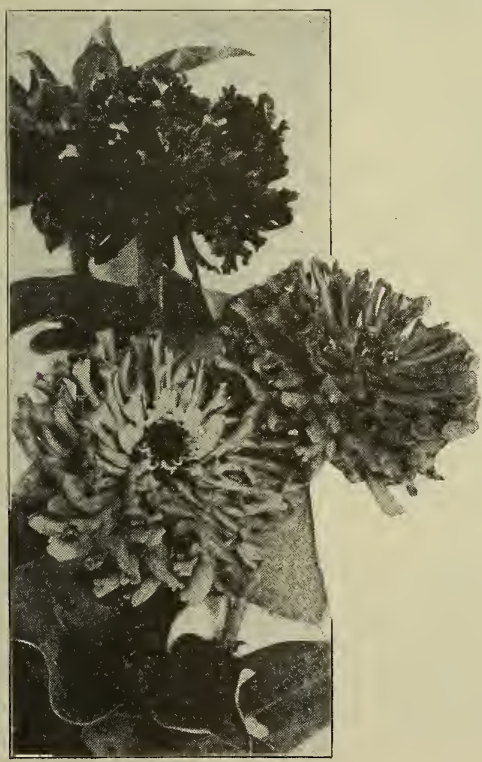

Very desirable. Easy to grow. Leaves covered with silvery down. Hardy annual. 2 feet. A very fine mixture of colors. Mixed-Pkt., $5 \mathrm{c}$.

\section{ZINNIA}

Few flowers are so easily grown from seed sown in the open ground, or bloom so abundantly and continuously as this hardy annual. Marvelous improvements have been wrought in the newer strains. Sow seed in the open ground early in spring. Height $11 / 2$ to 2 feet.

\section{DOUBLE POMPON}

Flowers small and of good shape; dout'e and of beautiful form; fine for bouquets. Fine mixed colors. Fkt., 5c.

\section{CURLED AND CRESTED}

(See Illustration)

The flowers of this fine class of Zinnias are large, full and double, the petals being twisted, rendering them free from stiffness. A variety of splendid colors. Pkt., 5c.

\section{ZEBRA}

Flowers of all colors, many of which are striped and spotted with different shades, hardly any two alike. Mixed colors. Pkt., 5c.

\section{GIANT FLOWERED MIXED}

A splendid mixture of all of the above and others. Pkt., 5c. 


\section{SWEET PEAS}

\section{GRANDIFLORA VARIETIES}

The Sweet Pea has become one of the most popular flowers in cultivation and is admired by all. For cutting for bouquets and for buttonhole wear, no flower except the rose can be compared with it. To succeed best they should be planted in moderately rich soil. Work the ground thoroughly as early in the spring as it can be done without making it sticky and hard; then make a trench about six inches deep and eight inches wide, at the bottom and sow the seed in double rows six inches apart, dropping from eight to fifteen seeds to the foot in each row. Cover with one or two inches of soil, and see that the ends of the trenches are open so that no water can stand in them. After the plants are about six inches high. fill up the trench. This method secures deep rooting (without danger of losing the seed from deep planting), which is essentiai to long continuous blooming. The plants should be given brush or strings to support them. They commence to bloom early, and if the flwers are picked off as soon as they fade, will cntinue to bloom all season. If pods are allowed to form, the plants soon stop flowering.

\section{HER MAJESTY}

(See Illustration)

The fiowers are very large, and both the standard and wings are beautifully curved, a delicate rose-pink color. 1/4 lb., 30c; lb., 60s.

\section{COUNTESS OF RADNOR}

One of the handsomest standard, rich lavender; wings lighte:. $1 / 4$ lb., 25c.

\section{AMERICA}

White, nearly covered with splashes, strins and dots of exceedingly bright camrine. The most brilliant of the red striped sorts. $1 / 4$ lb., $25 \mathrm{c}$.

\section{DAVIS' CHOICE MIXED}

This mixture contains all of the most choice new varieties and some of the old favorites. Pkt., 5c; oz., 10c; 1/4 lb., 30c: 1 lb., $\$ 1.00$.

\section{BRILLIANT}

Flowers of good size and substance, round and inclined to curve forward. Colors very brilliant. $1 / 4$ lb., 35c; lb., $\$ 1.20$.

\section{EMILY HENDERSON}

Extra large pure white. An early and wonderfully free and persistent bloomer. $1 / 4 \mathrm{lb} ., 35 \mathrm{c}$; lb., $\$ 1.20$.

\section{MRS. ECKFORD}

Pale primrose yellow, large and beautiful. $1 / 4 \mathrm{lb}$. 35c; lb., $\$ 1.20$.

\section{KATHERINE TRACY}

A delicate shade of pink, of very large size. $1 / 4$ lb., 35c.

\section{BLANCH FERRY}

Standard medium size, but of fine form and bright. Pink color, wings large, nearly white. $1 / 4 \mathrm{lb}$., $35 \mathrm{c}$

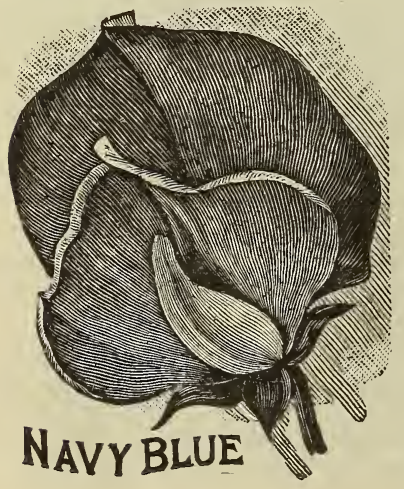

The wings and standard are a beautiful blending of rose-pink and lavenderblue shades, which vary as the flowers mature. 1/4 lb., 35c; lb., \$1.20.

\section{DOROTHY ECKFORD}

The grand pure white flowers are beautifully shell-shaped, of extra large size, splendid substance, and borne three on a stem. Per pkt., 5c; oz., 15c; $1 / 4$ lb., 40c; per lb., $\$ 1.50$.

\section{PHENOMENAL}

The flowers are silvery white. faintly suffused with soft pink, and beautifully edged with rich purple, afier the style of Lottie Eckford and Maid of Honor, but much larger. $1 / 4$ lb., 30c.; 1 lb., $\$ 1.00$.

\section{NAVY BLUE}

The large flowers are of a rich, glowing violet-purple, having the effect of dark navy blue, although on close examination the standards have a faint tinge of claret or wine red. The flowers are practically self-colored, and the deep rich coloring is grandly effective either alone or when in combination with other colors. Vines are of very strong, vigorous growth, continuous in bloom and wonderfully free flowering. $1 / 4 \mathrm{lb} ., 25 \mathrm{c} ; \mathrm{lb} ., 90 \mathrm{c}$. 


\section{SWEET PEAS}

\section{SPENCER VARIETIES}

This group includes the largest and most beautifully formed sweet peas. The typical Spencers have very large waved flowers, which are produced abundantly on long strong stems, making the blossoms most desirable for cutting.

\section{KING WHITE SPENCER}

Without exception the best and largest of ail Spencer sweet peas. It is of a purer white, of better substance, and more finely placed on thick, long stems, than White Spencer. The Standard is of the finest form, decidedly frilled and waved, while the wings are large. waved, and gracefully cover the keel, which also is of pure white and large form. The large flowers are generally borne four on a stem: the stems from 12 to 14 inches long. Undoubtedly, King White Spencer is superior in form, size and substance to all others. Pkt., 10c.

\section{ILLUMINATOR}

A rich and charming new color difficult to describe, produced by a ground color of salmony-orange, overlaid with bright cerise-pink, the effect being a glowing orange-scarlet, which is especially brilliant under artificial light; flowers uniformly large, perfectly formed, and borne on long stout stems. Pkt., 10c.

\section{WEDGWOOD}

Appropriately named, being a beautiful wedgwood or bright silvery-blue throughout, a color that has been wanted in the Orchid-Flowered class. The flowers are of modern Spencer size, finely formed and borne uniformly four to the spray. Pkt., 10c.

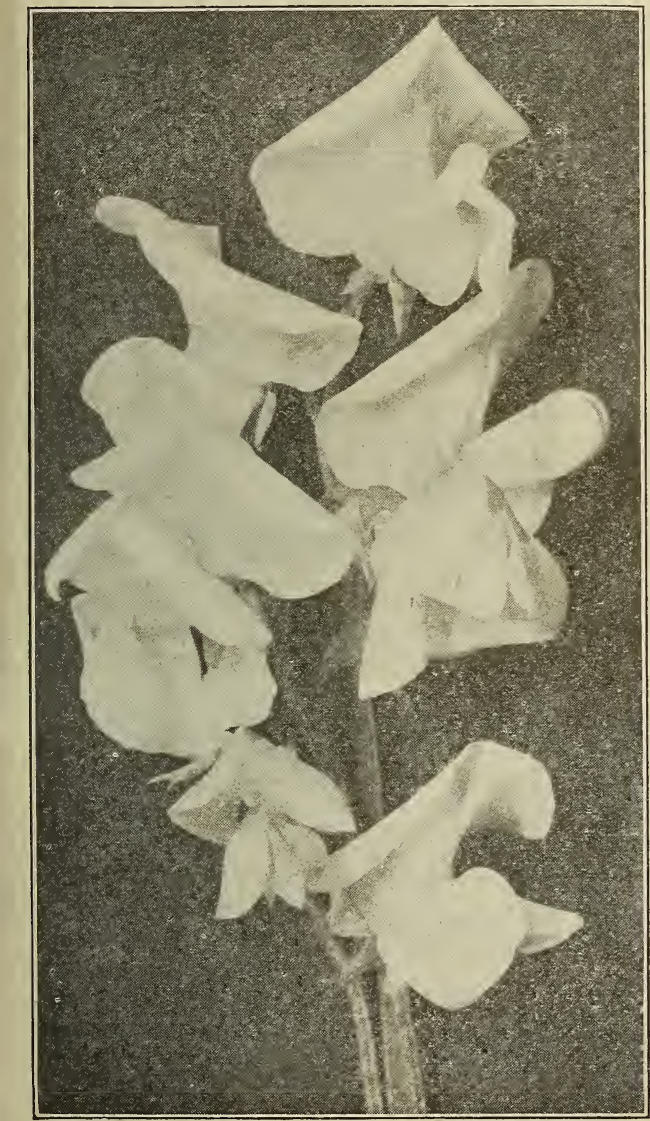

King White Spencer

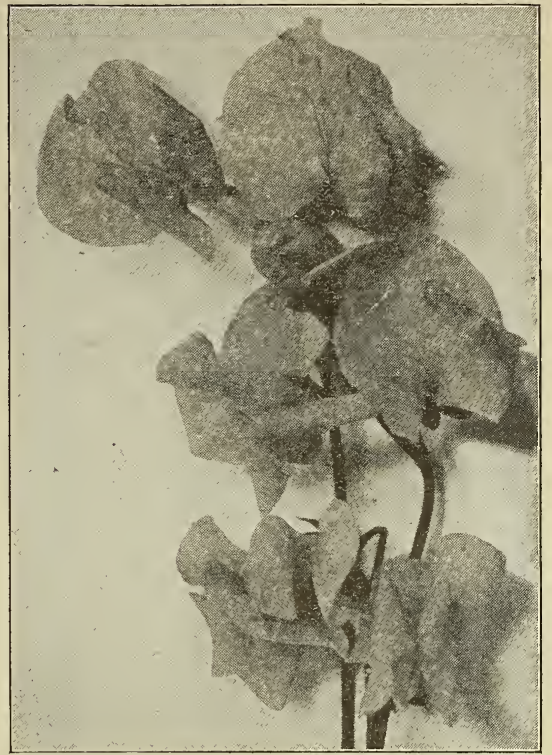

DUPLEX SPENCER

This beautiful cream-pink variety gives a large percentage of twin or triple standard flowers, which makes it very valuable in bunching for decorative purposes. All the flowers, borne frequently in fours, are finely waved and frilled. The vines are extremely vigorous and free flowering, the truly gigantic flowers being borne on very long stems, both standard and wings being rich creamy-pink with lemon colored keel. A most attractive and desirable variety, universally admired by all visitors. Pkt., 10c; 0z., 35c; $1 / 4$ lb., $\$ 1.00$.

\section{APPLE BLOSSOM SPENCER}

Bright rose standard with wings of very light primrose flushed or tinted rose carmine. Very large; best Spencer form. A free blooming sort and a very reliable high colored sweet pea of robust growth. Pkt., 10c; oz., 35c; $1 / 4$ lb., $\$ 1.00$.

\section{HELEN LEWIS}

A rich crimson orange, with wings of orange rose. Large, fine Spencer form. We consider this the finest reliable orange sweet pea. Pkt., 10c; oz., 35c; $1 / 4$ lb., $\$ 1.00$.

\section{KING EDWARD SPENCER}

Brilliant crimson scarlet; very large size and of open form. The best of the pure red or crimson Spencers. Pkt., 10c; oz.. 35c; $1 / 4$ lb., $\$ 1.00$.

\section{AMERICAN SPENCER}

Red flakes on white ground; extra fine. Pkt., 10c; oz., $40 \mathrm{c} ; 1 / 4 \mathrm{lb}$., $\$ 1.25$.

\section{QUEEN VICTORIA SPENCER}

Deep primrose, flushed with rose. Pkt., 10c; oz., $35 \mathrm{c} ; 1 / 4 \mathrm{lb}$., $\$ 1.00$.

\section{BLANCHE FERRY SPENCER}

Rose standard, pinkish-white wings. Pkt., 10c; oz., 35c; $1 / 4$ lb., $\$ 1.00$.

\section{SENATOR SPENCER}

Claret stripes on heliotrope ground. Pkt., 10c; oz., 35c; 1/4 lb., $\$ 1.00$.

\section{OTHELLO SPENCER}

Rich deep maroon. Pkt., 10c; oz., 35c; 1/4 lb., $\$ 1.00$.

The popular white. Pkt., 10c; oz., 40c; 1/4 lb., $\$ 1.25$. 


\section{Summer Flowering Bulbs and Roots}

All bulbs and roots will be sent by mail or express, charges prepaid, on receipt of price, except where noted. Not less than six at dozen rates, and not less than 25 at 100 rates. Orders should be sent us as early as possible, and they will be filled in rotation. Bulbs subject to injury by frost will not be sent until danger of frost is over.

\section{Caladium}

\section{ESCULENTUM (Elephant's Ear)}

One of the finest tropical plants which can be grown in the open air in the North. The leaves often exceed three feet in length and nearly as wide, and grow on stalks four to six feet high. Will grow in any good garden soil, but should have plenty of water. You cannot make the soil too rich or too wet for Caladiums. First size bulbs, 15c each, 4 for $50 \mathrm{c}$; second size bulbs, 10 c each, 50c per dozen.

\section{Cannas}

These very handsome tropical-looking plants are unrivaled for fine effect upon the lawn.

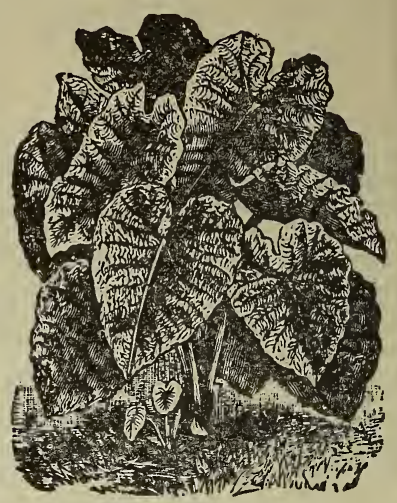

Esculentum Caladiums

AUSTRIA

Pure canary-yellow; fine, large open flowers, with few reddish dots in the centre of the two inside petals.

WYOMING

Purple foliage, giant Orchid-flowered, orange colored, large, round silken petals. Height. $7 \mathrm{ft}$.

\section{ITALIA}

Bright orange-scarlet, with broad golden-yellow border; the flowers are produced on massive stems, set well above the foliage which is large and heavy.

BURBANK

Green foliage. The flowers are gigantic in size. Toward the inner part the petals show fine crimson spots; all the rest of the flower is of a rich canary-yellow. $5 \mathrm{ft}$.

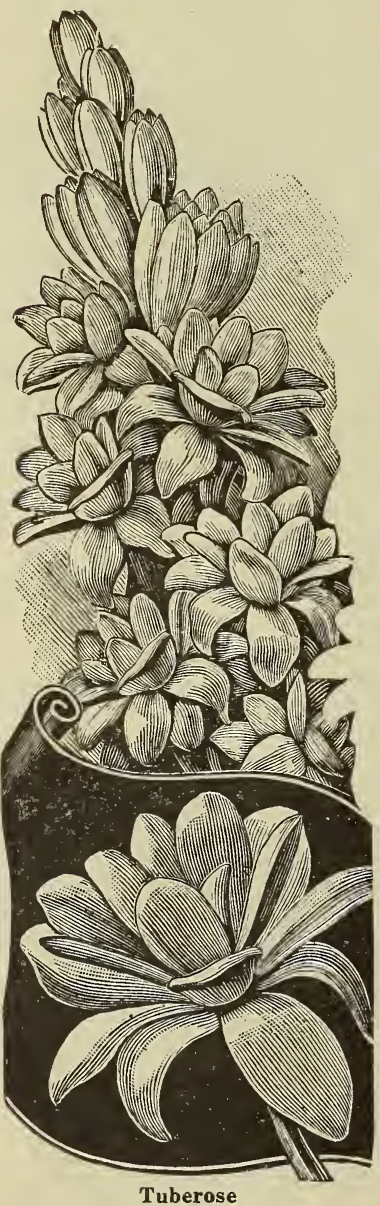

\section{ALLEMANIA}

Enormous flowers; outer petals scarlet, with broad yellow border; inside of bloom scarlet; fliage dark. 4 to $6 \mathrm{ft}$.

\section{KING HUMBERT}

An enormous orarge scarlet variety with bright red markings. Flowers measure 6 inches in diameter; very free blooming; foliage rich, coppery bronze, broad leaves. Height $5 \mathrm{ft}$. One of the finest show sorts.

\section{MADAM CROZY}

Vermillion with golden borders. Green foliage. Height $3 \frac{1}{2} \mathrm{ft}$.

\section{FLORENCE VAUGHAN}

Yellow with bright red spots. Foliage green. Height $31 / 2 \mathrm{ft}$.

\section{CHAS. HENDERSON}

Crimson scarlet with yellow throat. Enormous trusses. Foliage green. Height $3 \frac{1}{2} \mathrm{ft}$.

Any of the above Cannas $10 \mathrm{c}$ each; $\$ 1.00$ per dozen.

\section{LILIES}

Lilies are favorites everywhere. Their culture is simple, and with a little care failure is impossible. Plant bulbs from 3 to 5 inches deep.

\section{AURATUM}

The glorious gold-banded lily of Japan, and one of the grandest plants in cultivation. Its ivory-white flowers are thickly studded with yellow and crimson spots. While in the center of each petal is a golden band, fading at its edge into the white. 15c each; $\$ 1.50$ per dozen.

\section{SPECIOSUM ALBUM}

Pure white flowers with a greenish band through the center of each. They are of great substance and very fragrant. 15c each; $\$ 1.50$ per dozen.

\section{TIGRINUM}

Double Tiger Lily. This magnificent lily is of stately habit, bearing clusters of very large double flowers on tall, strong stems; color bright orange red, spotted with black. 15c each; $\$ 1.50$ per dozen.

\section{TUBEROSES}

One of the most delightfully fragrant and beautiful Summer-flowering bulbs. Its waxy-white flowers are the sweetest scented that grow. The growing plant is fond of light and heat and should not be planted outside before April 1.

Our Tuberoses are grown and cured with the greatest possible care, and all are flowering size. For large, perfect flowers we recommend the larger sizes.

\section{DOUBLE DWARF PEARL}

Each 5c; 40c per dozen; by express, \$1.50 per 100. 


\section{GLADIOLUS}

This class of summer-flowering bulbs is doubly valuablehandsome field show of bloom and for its generous supply of cut flowers. If the spikes are cut when the lowest flower first opens, the others will open in succession and remain fresh for a week or ten days. The Gladiolus has gained favor in public more rapidly than any other flowering bulb, because in addition to its great merit as a flower it is hardy and will thrive and bloom in any good garden soil. They require full sunlight, and are liable to injury only from rank manure. Plant the bulbs six to nine inches apart, the large ones four inches and the small ones two inches deep. Make an early planting of the smallest bulbs first as soon as the ground is sufficiently dry and warm. Continue to plant at intervals of two weeks during the spring and early summer; in this way a succession of bloom may be had from midsummer until frost. A free use of water during the season of active growth, and particularly as the buds begin to show color, will be beneficial in producing fine blossoms. In the autumn, before freezingi they should be dug up and the tops allowed to dry down, after which the dry tops, earth and old bulbs can be removed. Store in a cool, dry place, secure from frost, until spring.

\section{AMERICA}

The finest of the light-colored sorts. Very light pink, exquisitely tinted with lavender. Unsurpassed in freedom of bloom and size of flower spike. A magnificent variety. Each, 5c; dozen, 50c, postpaid.

\section{BARON HULOT}

Rich, deep indigo blue. Besides being the only blue Gladiolus known, it is a really very fine sort. Each, 8c; dozen, 75c, postpaid.

\section{AUGUSTA}

A lovely and useful variety, pure white with blue anthers. Each, 5c; dozen, 50c, postpaid.

\section{BLANCHE}

This is the finest white of the Giant type, immense flowers of pure white, lightly marked with pale rose; a gem. Each, 12c; dozen, $\$ 1.25$, postpaid.

\section{CHICAGO WHITE}

Pure white with faint lavender markings on the lower petals. Tall, straight stems. Early; fine bedding variety. Each, $8 c$; dozen, $75 c$, postpaid.

\section{HALLEY}

Delicate salmon-pink, slightly roseate, the lower petals showing a creamy blotch bisected by a red stripe. One of the earliest to bloom. Each, 5c; dozen, 50c, postpaid.

\section{ISAAC BUCHANAN}

A fine yellow. All flowers open at one time. Each, 8c; dozen, 75c, postpaid.

\section{KUNDERD'S RUFFLED GLORY}

A new departure in Gladiolus form, a reecntly developed strain having distinctly and beautifully fluted or ruffed petals. This "Glory" variety is of good size in flower and spike, with long stalks. Color, delicate cream pink, with a crimson stripe on each lower petal. Each, 8c; dozen, 75c, postpaid.

\section{MRS. FRANK PENDLETON, JR.}

A magnificent variety, which has won various awards on account of its practicability for cutting, as well as for its beauty. Every bud opens up in water fully and perfectly. Flowers are very large and well expanded, of a lovely flushed salmon-pink, with blood-red blotches in the throat. Each 15c; dozen, $\$ 1.50$, postpaid.

\section{MRS. FRANCIS KING}

One of the newer varieties of merit; very large and beautiful flowers ; color a light scarlet with crimson blotches. Each, 5c; dozen, 50c, postpaid.

\section{NIAGARA}

This superb flower is a seedling of America, and is, if anything, a little larger. It is a beautiful cream shade, a strong grower, and is fast making

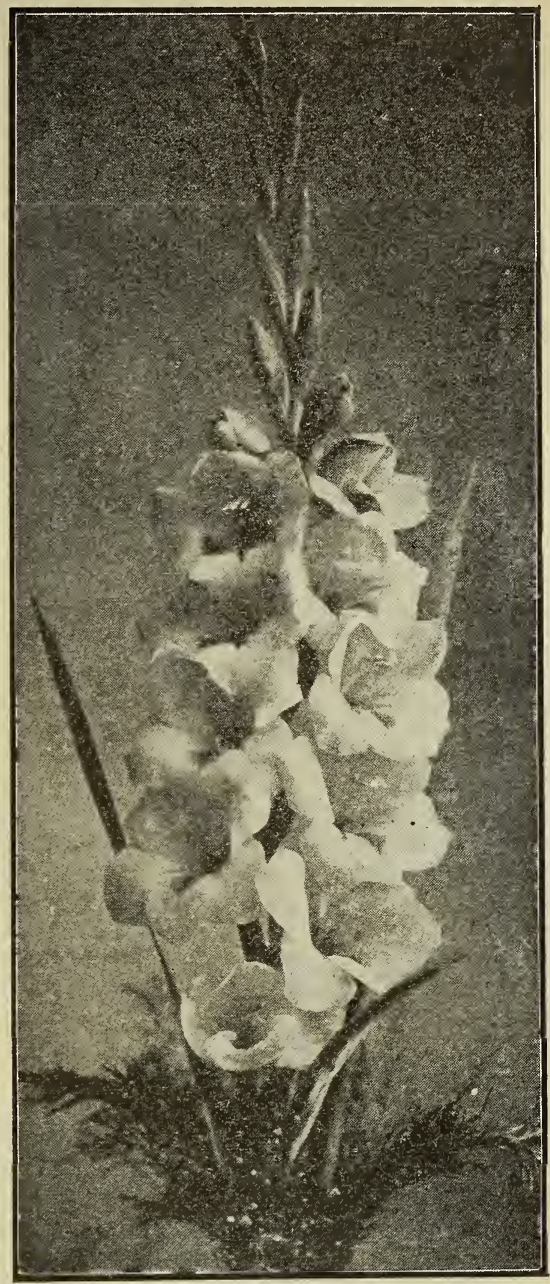

America

a place for itself in its color, just as America is far in the lead as a pink Gladiolus. Each, $8 \mathrm{c}$; dozen, 75c, postpaid.

PANAMA

A new seedling of America, but is a much deeper pink. A long spike with large, well arranged flowers. A grand variety which evokes words of praise wherever exhibited. Each, 15c; dozen, $\$ 1.50$, postpaid.

\section{SPECIAL}

One each of the above twelve varieties for $75 \mathrm{c}$; one-half dozen of each of the above, seventy-two bulbs in all, $\$ 4.00$.

\section{Gladiolus in Mixture}

\section{CHILDSIL HYBRIDS}

A mammoth-flowered strain with spikes of bloom sometimes two feet in length. Mixed. Each, 5c; dozen, 50c, postpaid. By express, $\$ 3.00$ per 100 .

\section{SUPERIOR MIXTURE}

Including many choice, showy, large-flowering varieties; all colors. Each, 5c; dozen, $50 \mathrm{c}$, postpaid. By express, $\$ 3.00$ per 100 .

\section{FINE MIXED}

Fine mixed seedlings. Well worth the money Each, 3c; dozen, 25c, postpaid. By express, $\$ 1.75$ per 100. 


\section{DAHLIAS}

The Dahlia is one of the most satisfactory of the Summer and Autumn flowering roots, producing an finf abundance of bright colored flowers from July until frost. The different varieties comprise all colors, from the purest white to the deepest maroon. Especially fine for cut flowers. Many of them are two or more colors with edged petals, some double with quilled petals, others with broad flat petals, some twisted and curled, and comprise many fancy shapes. There are several classes, and our list comprises the best varieties of each class.

\section{CULTURE}

A light, sandy soil is preferable for the best results; also a sunny exposure. Stir soil eight or ten inches deep; a foot will be better. Apply stable manure the Fall previous to the Spring you plant and work thoroughly into the soil to get best results.

Separate bulbs to one or two bulbs; plant deep, laying flat, and be sure to cover six inches deep, Don't stand on end with crown out. Give it a chance to root and get a firm hold before any chance of disturbance in cultivation. Keep the ground thoroughly stirred until they begin to bloom. Then stop and mulch with straw and manure or straw.

Apply water freely. If work in field is done with horse, plant three to four feet apart in rows and fifteen inches to two feet in the row. If for cut flowers, two feet and over give more flowers and larger ones.

To avoid stalking or breaking down after two sets of leaves show, pinch off the main stalk and they will branch and need no support; but this retards the bloom, which will be ten days or two weeks later.

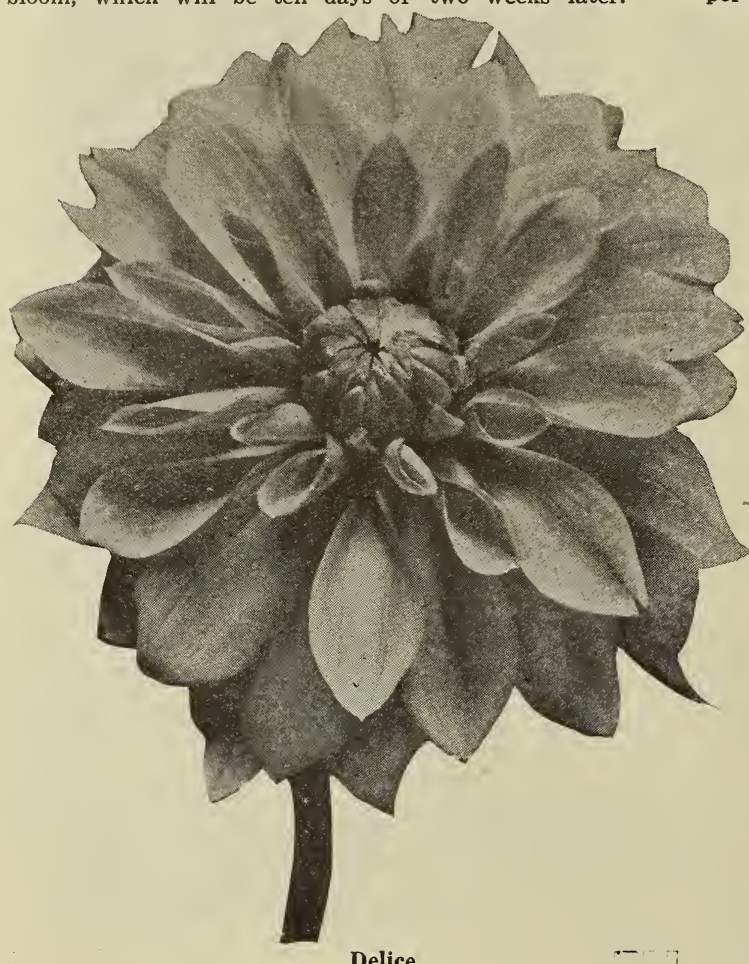

\section{CUBAN GIANT}

Flowers six to seven inches in diameter, dark, glowing, crimson-shaded maroon. A tall, strong grower, with projecting flower stems. 25c.

\section{CLIFFORD W. BRUTON}

A standard yellow variety; large and perfect. $15 \mathrm{c} ; \$ 1.50$ per doz.

\section{DELICE}

The most popular pink variety. Its beautiful, soft, yet lively color, a glowing rose pink, together with its perfect shape, stout, stiff stems, and the fact when cut it retains its freshness for a long time, makes this one of the most valuable for cutting or decorative sorts in the garden. 25c each; $\$ 2.50$ per doz.

\section{FLORA}

The best pure white Decorative, very large, early, profuse and continuous bloomer, on long stems. 20c each; $\$ 2.00$ per doz.

\section{GOLDEN WEDDING}

A giant in flower and plant. This is probably the largest of all the Dahlias, while the color is that deep golden yellow found in the Golden Wedding Chrysanthemum. Not only entirely distinct, but excellent in color, length of stem and size. A gorgeous variety for the garden or exhibition. 25c each; $\$ 2.50$ per doz.

\section{JACK ROSE}

The best crimson for garden of cutting; that brilliant crimson red that makes the "Jack" Rose popular and suggested the name. 15c each; $\$ 1.50$ per doz.

\section{MRS. J. GARDENER CASSATT}

A new pink variety which has attracted much attention for its beauty of form and color and great freedom of bloom. The flowers are immense and borne on long stems. It is a beautiful rose color. 25c each; $\$ 2.50$ per doz.

\section{MINNIE McCULLOUGH}

Very striking. Soft, golden yellow, tipped bronzy red; effective under the artificial light; perfect form, on long, stiff stems. 15c each; $\$ 1.50$ per doz.

\section{SOUVENIR de GUSTAVE DOAZON}

Of mammoth proportions, which, under ordinary cultivation, will produce flowers six inches across, and can be grown to measure full nine inches. It is of free growth, remarkably profuse-flowering, and pure red in color. 20c each; $\$ 2.00$ per doz.

\section{SYLVIA}

Soft, pleasing mauve-pink, gradually changng to pink in center. A fine cut flower. $15 \mathrm{c}$ each; $\$ 1.50$ per doz.

\section{WM. AGNEW}

Very large, dazzling crimson scarlet. Early and profuse bloomer. 15c; $\$ 1.50$ per doz.

\section{ZULU}

The black Dahlia. A great favorite. Velvety maroon, shaded black. $15 \mathrm{c}$ each; $\$ 1.50$ per doz.

\section{COLLECTION}

One each of the above Decorative Dahlias, labeled true to name, for $\$ 2.00$. 


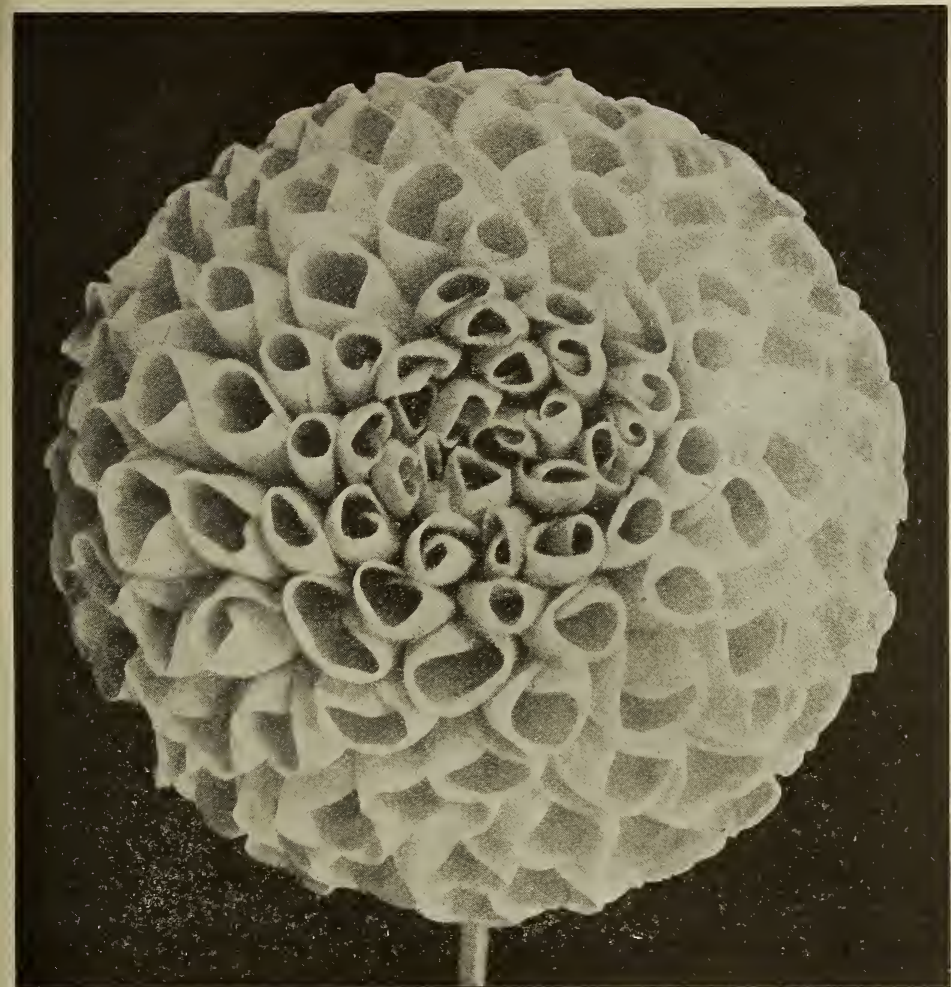

Show Dahlia, A. D. Livoni

\section{QUEEN OF THE YELLOWS}

Very large, globular flowers, with petals of good substance and full to the center. Color a fine, clear yellow; long, stiff stems, and fine for cutting. A very profuse bloomer. Best of its class. 15c each; $\$ 1.50$ per doz.

\section{COLLECTION}

One each of the above 8 varieties for $\$ 1.25$.

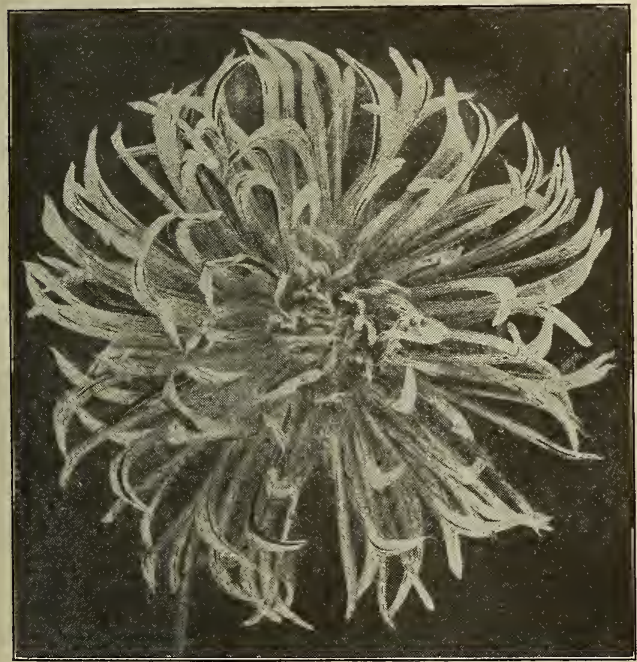

Jupiter

\section{Show or Fancy Dahlias}

They are especially desirable for large size, regular form, and beautiful colorings. This type of flower is most popular with the florists for early autumn cuttings; the flowers are all borne on long stems, and bunch easily.

\section{A. D. LIVONI}

A splendid clear pink, beautifully quilled, of perfect form and very free flowering. 15c each; $\$ 1.50$ per doz.

\section{ARABELLA}

Light sulphur-yellow, shaded peach-blossom on edges; a fine flower. 15c; $\$ 1.50$ per doz.

\section{BONTON}

Large, absolutely full, and of round, regular form, the petals reflexing to the stem. Color, deep rich crimson. A free bloomer on long stems. 15c each; $\$ 1.50$ per doz.

\section{DORTHY PEACOCK}

Very large, perfect shaped flowers of a brilliant sea-shell pink color; very early, free and continuous blooming. $30 \mathrm{c}$ each ; $\$ 3.00$ per doz.

\section{ETHEL MAULE}

A magnificent pure white, of largest size and fine form. $25 \mathrm{c}$ each; $\$ 2.50$ per doz.

\section{RED HUSSAR}

Richest dazzling cardinal red. Strong, vigorous grower and free bloomer, on long stems. Best red show dahlia for cutting. 15c each; $\$ 1.50$ per doz.

\section{WHITE SWAN}

Largest pure white; reliable. 15c each; $\$ 1.50$ per doz.

\section{Pompon Dahlias}

These are a miniature form of the show and fancy Dahlias, having the same round, ball-like form, but being much smaller. The plants are also much smaller, but no type produces as many flowers. The plants are literally covered, and as the blooms can be cut in straps, they are valuable as cut flowers.

Clear canary yellow. 15c.

\section{CATHERINE}

\section{LITTLE BEAUTY}

Soft silvery pink, closely quilled petals. LITTLE HERMAN

Cardinal red, tipped white.

STAR OF THE EAST

Pure white, long stems.

\section{SUNSHINE}

Richest vermillion scarlet, splendid little flowers on lcng stems.

\section{TOM}

Soft creamy yellow.

PRICE-Any of the above, 15c each; $\$ 1.50$ per doz.; $\$ 10.00$ per 100 .

\section{COLLECTION}

One each of the above 6 varieties of Pompon Dahlias for $75 \mathrm{c}$.

One each of the 41 varieties for $\$ 6.25$, by express. 


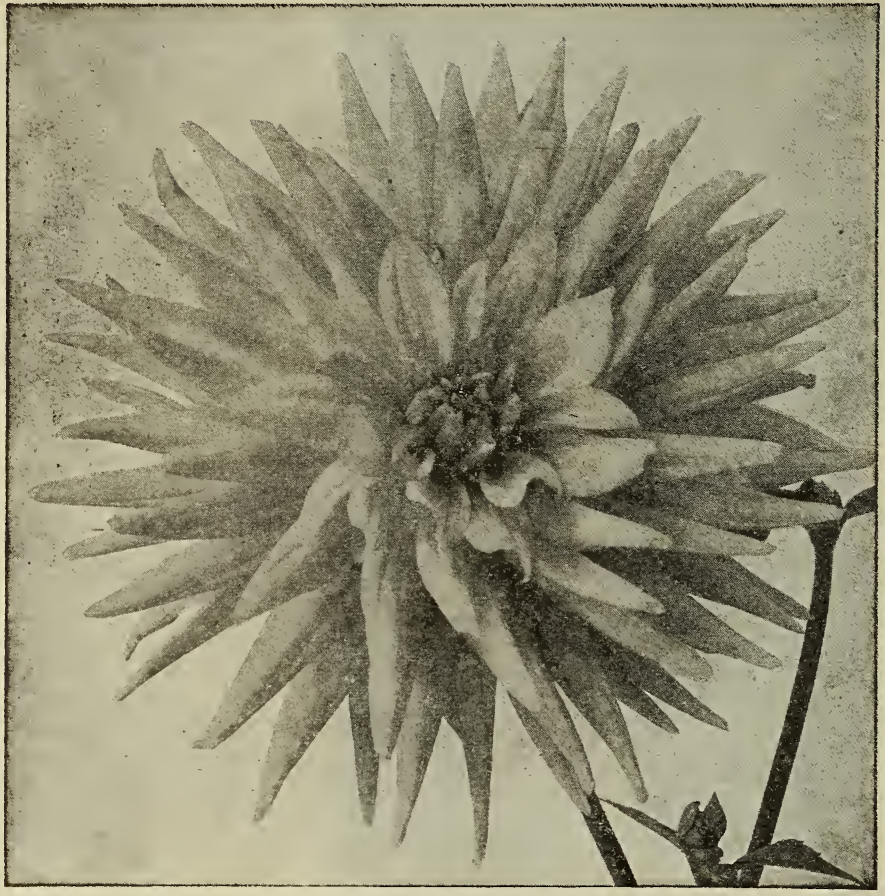

Golden Gate

GOLDEN GATE

This giant new variety should be called a decorative Cactus-it is so large, the stems so long and erect, that it has become one of the most valuable for decorations. The color is of a rich golden yellow, suffused 'and shaded rich red, making it one of the best of the popular Autumn shades. The flowers are of largest size, specimen blooms as large as eight to ten inches in diameter on two to three stems. The plant is remarkably strong, sturdy and vigorous, growing six feet high and producing giant flowers on those long, stiff stems freely until cut down by frost. 50c each; $\$ 5.00$ per doz.

\section{MARJORIE CASTLETON}

Rosy-pink, tinted lighter toward center and tips. $25 \mathrm{c}$ each; $\$ 2.50$ per doz.

\section{MONT BLANC}

A beautiful pure white cactus of splendid form, long, stiff stems, and absolutely full to the center. $15 \mathrm{c}$ each; $\$ 1.50$ per $\mathrm{doz}$.

\section{TRICOLOR}

Everybody likes Tricolor on account of its distinct and beautiful medley of colors. The ground is butter-cup yellow, with a blotch of scarlet on each petal, and as the flower matures the end of each petal becomes suffused with rosy-white, forming a pretty tricolor combination. $30 \mathrm{c}$ each; $\$ 3.00$ per doz.

\section{T. G. BAKER}

Very large, finely formed flowers on long, stiff stems. The best clear bright yellow cactus. 20c each; $\$ 2.00$ per doz.

REV. A. HALL

Ruby crimson, of largest size, with long, narrow incurved petals. 25c each; $\$ 2.50$ per doz.

UNCLE TOM

Dark maroon, shaded black. 15c each; $\$ 1.50$ per doz.

\section{COLLECTION}

One each of the above 10 varieties for $\$ 1.75$.

\section{Paeony-Flowered Dahlias}

This beautiful type is now very popular. The artistic flowers are very large, and are best compared to the semi-double Peonies in general form.

They all flower very freely, and are borne on long,

\section{Cactus Dahlias}

This type has become wonderfully popular of late years, until now there are hundreds of varieties offered, making it very confusing for the amateur to make a selection. We have endeavored to list some of the meritorious of the new varieties and the best of the standard varieties.

\section{CHARLES CLAYTON}

The strongest words of praise are not extravagant when applied to this wonderful Cactus. Stems are long, holding the flowers well above the foliage. The color is a most intense red, so vivid as to dazzle the eye. Flowers are large in size and are produced freely. 20c each; $\$ 2.00$ per doz.

\section{COUNTESS OF LONS-}

\section{DALE}

Longest season and freest bloom of any Cactus type; flowers very large, complete and perfect color, and exquisite blending of amber and salmon-pink. 15c each; $\$ 1.50$ per doz.

\section{JUPITER}

Ground color at base of petals yellow, passing to salmon-rose at the tips, the whole splashed and striped with crimson. 35c each ; $\$ 3.50$ per doz. strong stems, making excellent material for cutting, as well as for garden decoration.

\section{GERMANIA}

Brilliant strawberry-red; a very fluffy, artistic flower. 25c each; $\$ 2.50$ per doz.

\section{JOHN WANAMAKER}

(See cut on back page of cover)

This we consider the best Peony-flowered dahlia that we have seen. It is not only one of the largest and handsomest, but has a distinctly new habit of branching, or stooling, right at the ground.

The color is an exquisite and fashionable shade of rose lake, or, as popularly called, Orchid-Pink. As the flower develops, the color softens, and must be seen to be fully appreciated. The illustration on back cover is from a photograph, and show the exquisite formation, no two. petals alike, and no two flowers exactly alike; yet so alike in their irregularity. It is that careless abandon of all set rules of regularity that first attracts and then holds the attention of the flower lover. $\$ 1.00$ each; $\$ 10.00$ per doz.

\section{GEISHA}

The showiest and most attractive of this type yet introduced; of strong growth, with the rich-colored flowers, which are frequently over eight inches in diameter, standing well above the foliage. These are original in form, consisting of peculiarly twisted and curled petals, of an effective and rich combination of scarlet and gold, the center being yellow, which becomes suffused with and deepens to scarlet at the center of the petals, shading off lighter at the edges. 35c each; $\$ 3.50$ per doz.

MRS. CHAS. L. SEYBOLD

Ground color crimson-carmine, each petal tipped and more or less marked with white; produced very freely. 25c each; $\$ 2.50$ per doz.

\section{QUEEN WILHELMINA}

Immense fluffy flower of pure white with yellow center. 25c each; $\$ 2.50$ per doz.

\section{COLLECTION}

One each of the above 5 varieties for $\$ 1.75$. 


\section{HARDY STANDARD ROSES}

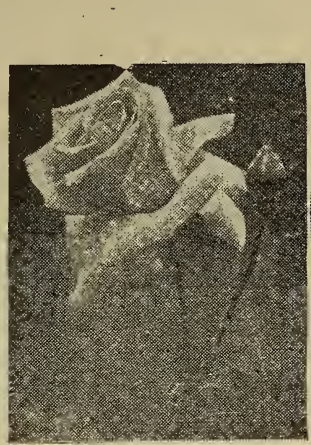

La France

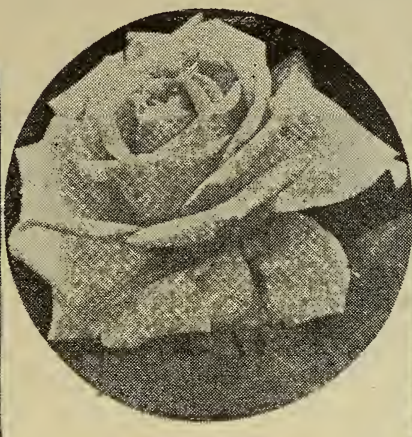

Paul Neyron

\section{A Legend of the Rose}

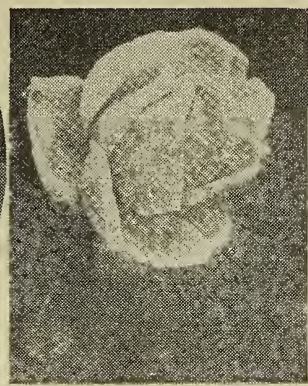

Margaret Dickson

The Queen of Flowers was originally white and thornless. One bright, sunny June morning, Cupid bent lovingly over his favorite and lightly touched his pretty lips to her trembling petals. The siss of love was rudely rebuked by the sting of a bee that had sought nectar from the heart of the rose. A single drop of Cupid's blood fell upon the pure white bosom of the Flower Queen. In an instant, it spread over her whole being. Cupid, wild with rage and pain, ran screaming to Venus, his mother, who appeased the boy by stringing his bow with bees and placing their poisonous stings on the slender stems of the Rose.

Strong, 2 yr. old plants. HARDY

GRUSS AU TEPTLITZ

Beautiful crimson red, wonderful free flowering. 40c each.

\section{CAROLINE TESTOUT}

Large deep pink, especially good for cut-flowers. $40 \mathrm{c}$ each.

Continual bloomer of a soft delicate pink with satin tinge. $40 \mathrm{c}$ each.

\section{MARGARET DICKSON}

Large white rose with a pale flesh center, petals very large. 40c each.

\section{PAUL NEYRON}

Deep red rose, upright grower with very large flowers. $40 \mathrm{c}$ each.

MADAM PLANTIER
Pure white, an old reliable variety. Blooms abundantly. 40c each.

\section{LA FRANCE}

A delicate silvery pink rose. Continual bloomer, fragrant. $40 \mathrm{c}$ each.

GENERAL JACQUIMENOT

Brilliant crimson, large and extremely effective, beautiful. 40c each.

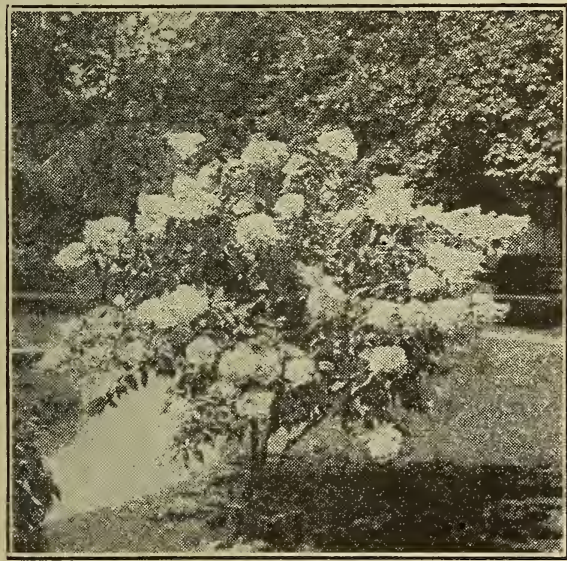

Hydrangea Grandiflora

\section{Climbing Roses}

\section{CRIMSON RAMBLER}

Most popular of all climbers. Hardy, thrifty, abundant bloomer. 35c each.

\section{DOROTHY PERKINS}

Pink, free flowerer. A good companion for Crimson Rambler. 35c each.

\section{TAUSENDSCHON}

A hardy pink bloomer of exquisite beauty. 35c each.

\section{HARDY ORNAMENTAL SHRUBS}

\section{ALTHEA OR ROSE OF SHARON}

A valuable shrub for its abundant, variously colored flowers. Can be used separately or in groups. 2 to 3 feet. 35c each.

\section{BARBERRY PURPLE-LEAVED}

A very attractive shrub with purple leaves which makes it valuable for massing with other plants. 2 to 3 feet. $35 \mathrm{c}$ each.

\section{BARBERRY THUNGBERGEII}

A valuable plant for its low, drooping habit and attractive for its profusion of scarlet fruit. $11 / 2-2$ feet. 25c each.

\section{CALYCANTHUS OR SHRUB}

A unique shrub with chocolate red flowers of special fragrance. 2-3 ft. 50c each.

\section{DEUTZIA}

A very ornamental shrub with snowy white flowers and slender arching branches. $2-3 \mathrm{ft}$. 35c each.

\section{BUSH HONEYSUCKLE}

Valuable for its white or pink flowers and berries which follow. Very attractive and ornamental. 2-3 ft. $35 \mathrm{c}$ each.

SYRINGA OR MOCH ORANGE

A fine old shrub with white or pink flowers, blooming in June. This shrub grows tall, very useful for background and screens. 2-3 ft. 25c each. HYDRANGEA GRANDIFLORA

The most popular widely planted shrub in cultivation. Very beautiful and hardy with large flowery panicles. 2-3 ft. 25c each. 


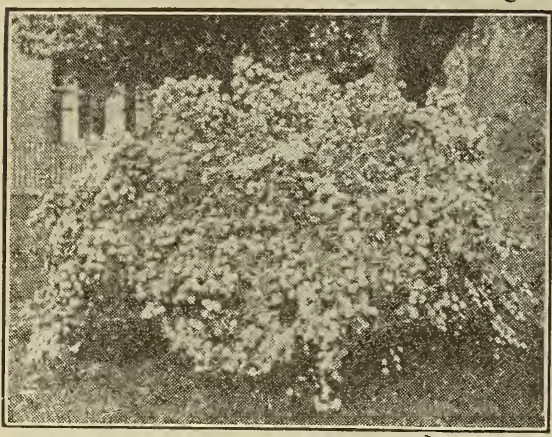

Spirea Van Houtti or Bridal Wreath

\section{Climbing Vines \\ BOSTON IVY}

An old reliable climber with dense, green leaves overlapping each other. Grows rapidly and clings firmly, changing to scarlet in the fall. $25 \mathrm{c}$ each. CLEMATIS

Flowers are pure white, fragrant and dense with clean glossy foliage. Should be cut back to the ground each spring. Very rapid grower. 30c each. WISTARIA

Very strong grower. It climbs high and twines tightly. Blooms very profusely in summer. Flowers blue in clusters. $30 \mathrm{c}$ each.

\section{Hedge Plants \\ IBOTA PRIVET}

A very hardy shrub, growing vigorously in northern sections similar to the California Privett. 18-24 inches. $\$ 12.00$ per 100 .

\section{BABERRY THUNGBERGEII}

Very useful for ornamental and hedges, of dwarf habit with small foliage changing to a beautiful coppier red color in the late fall. 12-18 inches. $\$ 20.00$ per 100 .

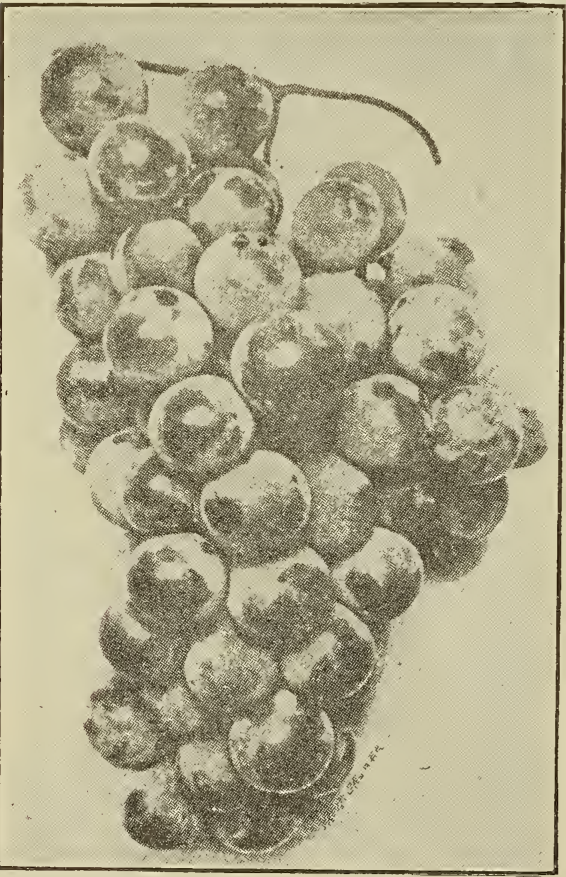

Grapes

\section{Hardy Ornamental Shrubs}

\section{LILACS}

An old reliable shrub blossoming in May with dense panicles of flowers of the most delicious fragrance. 2-3 ft. $35 \mathrm{c}$ each.

\section{SPIREA VAN HOUTTI OR \\ BRIDAL WREATHE}

The best variety of Spirea with long and graceful, arching branches. universally used. Very hardy. 3-4 ft. 35c each.

\section{SPIREA ANTHONY WATERER}

A very attractive shrub with clusters of dark cirmson flowers. Dwarf habit rarely grows over three feet in height. $15-18$ in. $35 \mathrm{c}$ each.

\section{JAPANESE SNOWBALL}

A vigorous spreading shrub dark green leaves with bronze margin. Blossoms in spring. Compacted white clusters. 2-3 ft. 35c each.

\section{WEIGELIA}

A tall spreading shrub with large and showy flowers of dark carmine. Blooms profusely. 2-3 ft. 35c each.

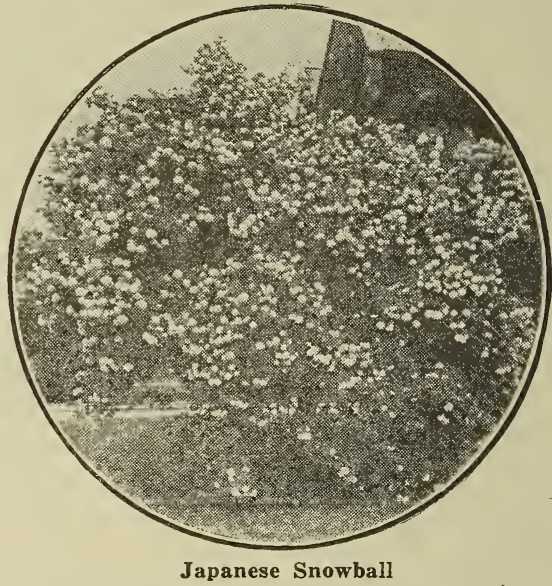

\section{CALIFORNIA PRIVET}

Useful both for hedge and ornamental purposes, grows most anywhere, with vigorous green foliage which may be trimmed to any shape. Instructions for transplanting furnished free upon application. $18-24$ inches. $\$ 5.00$ per 100 .

\section{Decidious Trees}

\section{CATALPA BUNGEI}

A remarkable dense, round-headed bush, grafted upon a straight and upright stems. Very effective for lawns and formal gardens. $\$ 1.00$ each.

\section{NORWAY MAPLE}

A round-headed handsome tree, with large green leaves which hold their color until very late in autumn. 8-10 ft. $\$ 1.25$ each.

\section{SCHWEDLERI'S PURPLE-NORWAY MAPLE}

Very similar to the Norway in habit, but with bright crimson foliage in early spring which afterwards fades to a purply green. 6-8 ft. $\$ 1.00$ each.

\section{WEEPING MULBERRY}

Forms a perfect umbrella head with long slender branches and droops to the ground parallel with the stem. $\$ 1.00$ each.

\section{GRAPES}

\section{CONCORD}

A large purplish-black grape, very hardy and productive. 20c each.

\section{BRIGHTON}

Very fine quality, with red, sweet, tender berries. 25c each. 


\section{Grapes \\ DELAWARE}

A very hardy, productive grower of red, small compacted berries. Very sweet and juicy. 25c each. NIAGARA

The best table grape on the market. White, large and compacted berries, very vigorous and productive. 25c each. DIAMOND

9A large greenish-white claimed by some to be the leading white grape even superior to Niagara, very hardy. 50c each.

\section{WORDEN}

Similar to Concord, but ripen earlier with a larger berry and a better quality and productiveness. $35 \mathrm{c}$ each.

\section{Raspberries}

\section{ST. REGIS}

The only EVERBEARING raspberry on the market. It is one of the earliest bearers and bears continually until late fall. It is wonderfully prolific, with large bright crimson berries of remarkable keeping quality. Extremely hardy. 5ic per dozen.

\section{CUMBERLAND}

The best of the black raspberries. Berries are large, attractive and of splendid quality. The greatest commercial variety. 25c per dozen.

\section{Gooseberries}

\section{DOWNING}

Light green, large, fine flavor, very hardy and seldom mildews. Most profitable for market. \$1.50 per dozen. HOUGHTON

A medium sized red berry, noted for its heavy yearly crops of the best quality. $\$ 1.25$ per dozen.

\section{Blackberries}

\section{BLOWERS}

The finest blackberry of the best quality, having no perceptible core. $\$ 1.00$ per dozen.

\section{RATHBUN}

Very large, .sweet and luscious. Very productive and a remarkable good shipper. $\$ 1.00$ per dozen.

\section{Currants}

\section{FAY'S PROLIFIC}

The leading market currant, large red berries of uniform size, easy to pick and wonderfully prolific. The leading currant variety. $\$ 1.00$ per dozen.

\section{WHITE GRAPE}

Best of the white currants. Universally light for its flne pleasant flavor and large berries. \$1.25 per dozen.

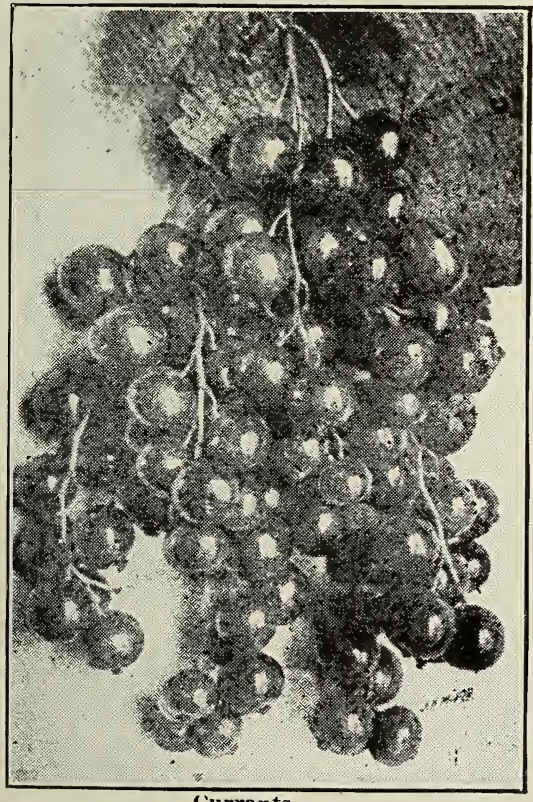

Currants

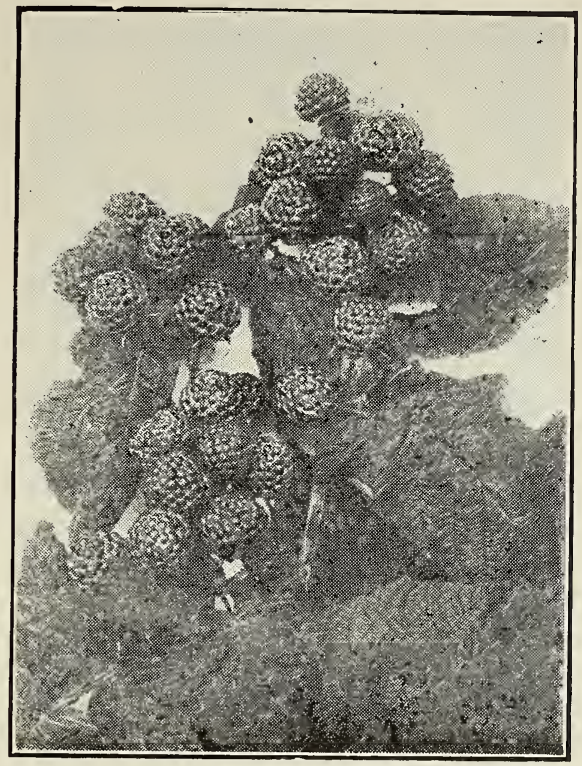

\section{Strawberries}

\section{AROMA}

Absolutely the best shipper and market variety. Very dark red, large of very good quality and productiveness. $75 \mathrm{c}$ per 100 .

SENATOR

An old reliable variety, highly recommended for all purposes.

Good keeper and very productive. 60c per 100.

\section{SUPERB}

Absolutely the best EVERBEARING variety. Bears continually from early summer until late frost. Undoubedtly the wonder of the Berry World. $\$ 2.50$ per 100 .

\section{PEACHES}

BANNER

Large round yellow with a crimson cheek. Originated in Canada. 4 to 6 feet. 25c each.

\section{BOKARA}

A large yellow peach of excellent quality. Especially adapted to market on account of its freedom of injury. Tree one of the hardiest and best bearers. 4 to 6 feet. 25c each.

CHAMPION

Large round, creamy, yellow. Flavor, delicious, sweet and juicy. 4 to 6 feet. $25 \mathrm{c}$ each.

\section{ELBERTA}

Very large. The best and widest known of all yellow peaches. A standard of the peach world. Good grower and abundant bearer. 4 to 6 feet. 25c each.

\section{HEATH'S CLING}

Very large; creamy white. The best of all the cling variety. Splendid for markct and canning. 4 to 6 feet. 25c each.

BELLE OF GEORGIA, 4 to 6 feet, 25c Each.

CARMAN, 4 to 6 feet, 25c Each.

CHILI, 4 to 6 feet, 25c Each.

CROSBY, 4 to 6 feet, 25c Each.

CRAWFORD'S EA., 4 to 6 feet, 25c Each.

GRAWFORD'S LA., 4 to 6 feet, 25c Each.

KALAMAZOO, 4 to 6 feet, 25c Each.

MOUNTAIN ROSE, 4 to 6 feet, 25c Each.

SMOCK, 4 to 6 feet, 25c Each.

TRIUMPH, 4 to 6 feet, 25c Each. 


\section{APPLES}

\section{Summer Varieties \\ EARLY HARVEST}

Medium, pale yellow. Tree erect grower and good bearer. An excellent home apple. 5 to $7 \mathrm{ft}$. 30c each.

\section{YELLOW TRANSPARENT}

Good size, clear white turning to yellow, sub-acid, good for cooking and eating. Also a good market variety. Very hardy. 5 to 7 ft. 30c each.

RED ASTRACHEN

30c each.

SUMMER QUEEN

5 to 7 feet. 30c each.

GOLDEN SWEET

5 to 7 feet. 30c each.

\section{Fall Varieties}

\section{MAIDEN BLUSH}

The best fall variety of medium size. A good market sort and very attractive in appearance. 5 to $7 \mathrm{ft}$. $30 \mathrm{c}$ each.

\section{DUCHESS}

A large sized apple streaked with red. Tree vigorous grower and very hardy. A little earlier than the Maiden Blush. 5 to $7 \mathrm{ft}$. 30 ceach.

FALL PIPPIN

5 to 7 feet. $30 \mathrm{c}$ each.

FAMEUSE

5 to 7 feet. $30 \mathrm{c}$ each.

GRAVENSTEIN

5 to 7 feet. 30c each.

PEWAUKEE

5 to 7 feet. 30c each.

RAMBO

5 to 7 feet. 30c each.

TWENTY OUNCE PIPPIN

5 to 7 feet. $30 \mathrm{c}$ each.

\section{Winter Varieties}

BALDWIN

Medium sized bright red. Tree vigorous. Abundant crops. 5 to 7 feet. 30c each.

\section{GRIMES GOLDEN}

Medium sized golden yellow, firm crisp apple of the very best quality. 5 to 7 feet. 30c each.

\section{JONATHAN}

Medium sized yellow nearly covered with red. Delicious and strictly dessert apple, always demands the highest market prices. 5 to 7 feet. 30c each. NORTHERN SPY

Undoubedtly the best of all Winter Varieties. A large roundish apple of fine quality and productiveness. 5 to 7 feet. 30c each.

\section{N. W. GREENING}

A large round green turning to a yellowish green when ripe. The very best of the green colored apples. Very hardy and productive. 5 to 7 feet. $30 \mathrm{c}$ each.

\section{DELICIOUS}

The neweat winter variety. Very fine flavor and productive. Extremely popular. 5 to 7 feet. $50 \mathrm{c}$ each.

\section{WEALTHY}

Medium sized, roundish and nearly covered with dark red. Tree good grower and productive. 5 to 7 feet. $30 \mathrm{c}$ each. WINESAP

Medium sized, deep red, flesh yellow, firm and juicy. Very productive. 5 to 7 feet. 30 c $\mathbf{e a c h}$.

5 to 7 feet. $30 \mathrm{c}$ each. ARKANSAS

5 to 7 feet. $30 \mathrm{c}$ each. ROME BEAUTY

5 to 7 feet. $30 \mathrm{c}$ each.

WOMPKINS KING

5 to 7 feet. 30c cach.

5 to 7 feet. $30 \mathrm{c}$ each. YELLOW BELLEFLOWER

5 to 7 feet. 30c each.

5 to 7 feet. $30 \mathrm{c}$ each.

\section{Cherries}

\section{DYEHOUSE}

Medium sized, red, juicy with a tart flavor. Tree hardy and upright. 5 to 7 feet. $40 \mathrm{c}$ each.

\section{MONTMORENCY}

Large, round, handsome red. Undoubtedly the best of all sour varieties. Tree good grower, hardy and productive. 5 to 7 feet. $40 \mathrm{c}$ each.

\section{EARLY RICHMOND}

Medium sized red, acid flavor. One of the best of the acid flavors and not surpassed in cooking. 5 to 7 feet. $40 \mathrm{c}$ each.

\section{SPANISH}

Large pale yellow with red cheek. One of the best of the early sweet cherries. 5 to 7 feet. $50 \mathrm{c}$ each.

\section{Pears}

BARTLETT 5 to 7 feet. $40 \mathrm{c}$ each. CLAPP'S FAVORITE 5 to 7 feet. $40 \mathrm{c}$ each. FLEMISH BEAUTY 5 to 7 feet. 40c each. LAWRENCE 5 to 7 feet. 40c each. KOONCE 5 to 7 feet. $40 \mathrm{c}$ each. SECKEL 5 to 7 feet. $40 \mathrm{c}$ each. KIEFFER 5 to 7 feet. $40 \mathrm{c}$ each. VERMONT BEAUTY 5 to 7 feet. $40 \mathrm{c}$ each. WORDEN 5 to 7 feet. $40 \mathrm{c}$ each. DROUARD 5 to 7 feet. $40 \mathrm{c}$ each.

\section{BLACK TARTARIAN}

Very large purplish black, heart shaped. The very best late, sweet cherry. Abundant bearer. 5 to 7 feet. 50c each.

5 to 7 feet. 50c each.

\section{NAPOLEON}

5 to 7 feet. 50c each. WOOD

5 to 7 feet. $40 \mathrm{c}$ each.

$$
\text { BALDWIN }
$$

\section{ENGLISH MORELLO}

5 to 7 feet. 40 c each. MAY DUKE

5 to 7 feet. $40 \mathrm{c}$ each. LATE DUKE

5 to 7 feet. $40 \mathrm{c}$ each.

\section{Plums}

BRADSHAW 5 to 7 feet. $40 \mathrm{c}$ each. LOMBARD 5 to 7 feet. 40ceach. ABUNDANCE 5 to 7 feet. $40 \mathrm{c}$ each. BURBANK 5 to 7 feet. $40 \mathrm{c}$ each. DAMSON 5 to 7 feet. $40 \mathrm{c}$ each. IMPERIAL GAGE 5 to 7 feet. $40 \mathrm{c}$ each. PRIDE 5 to 7 feet. $40 \mathrm{c}$ each. REINE CLAUDE 5 to 7 feet. $40 \mathrm{c}$ each. RED JUNE 5 to 7 feet. $40 \mathrm{c}$ each. WICKSON 5 to 7 feet. $40 \mathrm{c}$ each. 


\section{INSECTICIDES AND FUNGICIDES}

\section{LIME-SULPHUR SOLUTION}

This has been adopted as the Standard remedy by nearly all of the experimental stations and the U. S. Department of Agriculture for destroying San Jose, Oyster Shell Scale and similar insects as a winter spray while the trees are dormant. It is applied in diluted form of 1 gallon Lime Sulphur to 9 gallon: of water. As a Summer spray it is to be diluted 1 to 40 . It acis both as an insecticide and a fungicide, killing the spores of fungi, and a constant poison for sucking insects and mites.

Our Lime-Sulphur Solution is a clear cherry color, free from sediment, and cannot clog the nozzles. It is very strong, testing $32 \%$ to $33 \%$ Baume. The value of Lime-Sulphur Solution as an Insecticide consists principally in the amount of Sulphurated $\mathrm{Hy}$ drogen gas that it gives off, and our solution is manufactured in the most highly concentrated form for effective results. Lime-Sulphur is being largely used as a Summer spray now, and is especially desirable as a mixture with Arsenate of Lead, the proportion usually being 1 gallon of Lime Sulphur and 2 lbs. of Arsenate of Lead to 40 gallons of water. Prices: Per qt., 25c; $1 / 2$ gal., 40c; gal., 60c; 5 gal., $\$ 1.50$; $1 / 2$ barrel (25 gal.), $\$ 4.50$; barrel (about 50 gal.), $\$ 7.00$. Special prices in large lots.

\section{PARIS GREEN}

A strong and effective poison for potato bugs an 3 other leaf-eating insects. Can be applied either dry or in a solution of water; if dry, use Leggett's Dry Powder Gun or Beetle Duster (see implements) ; if diluted, use one pound of Green to 100 to 200 gallons of water, or $1 \mathrm{lb}$. to $100 \mathrm{lbs}$. of Land Plaster. Paris Green acts a little quicker than Arsenate of Lead, but washes off more easily. It is better to use on garden crops or tobacco, and Arsenate of Lead is best for trees. Paris Green and Bordeaux Mixture give excellent results on potatoes, the Green killing the bugs and the Bordeaux preventing blight. Price fluctuates. Present price: $1 / 2 \mathrm{lb} ., 15 c ; 1 b ., 25 c ; 5$ lbs. at 20c; 100 lbs., about $18 \mathrm{c}$ per lb.

\section{ARSENATE OF LEAD}

One of the best and most effective of poisonous insecticides for leaf-eating insects, and more especially adapted to trees and shrubs, as it adheres to the foliage better. It is not so liable to be washed off by rains, nd does not burn. We can supply Arsenate of Lead either in paste form to be diluted with water 3 lbs. to 50 gallons, or in dry form for dusting or dissolving. The dry form is about twice as strong as the paste and sells at higher price. For tender plants use a weaker solution, say 2 to 50 .

Paste Form Arsenate of Lead-1 lb., 20c; 5 lbs., 15c per lb.; 25 lbs., 13c per lb.; $100 \mathrm{lbs}$. and over, 10 per $l b$.

Dry Arsenate of Lead-1 lb., 30c; 5 lbs., 25c per lb.; 25 lbs., 22c per lb.; 100 lbs., 20c per lb.

\section{BORDEAUX MIXTURE}

For blight, mildew and all fungous diseases. Can be used alone or in connection with Paris Green or Arsenate of Lead. For hardy foliage such as apple, pear, potato, tomato, egg plant, use 3 to $4 \mathrm{qts}$. in 50 gallons of water. For tender foliage such as peach, cherry and cucumber, 2 to 3 qts. in 50 gallons of water.
Bordeaux Mixture Paste-Pt., 15c; qt., 25c; gal., 85c.; 5 gals., 34.25 ; $1 / 2$ bbl. (25 gals.), $\$ 11.25$; bbl. (50 gals.), $\$ 20.00$.

Bordeaux Mixture Dry-Per lb., 25c; 5 lbs., 85c; 50 lbs., $\$ 6.50 ; 100$ lbs., $\$ 12.00$.

\section{WHITE HELLEBORE}

For destroying Cabbage worms, Lettuce worms, Currant worms and other insects on vegetables, flow: ers and shrubs. It is not so poisonous as the Arsenicals, consequently better to use where these ar to be eaten. It can be dusted on or made into a solution and sprayed. 1/2 Ib., 15c; lb., 25c.

\section{HAMMOND'S SLUG SHOT}

One of the best insecticides for Vegetables in use. Specially recommended for destroying the Cabbage worm, Potato bug,, Tobacco worm and other insects that prey on vegetables. Gardeners need have no fear about applying this, as it is not dangerous to handle like Paris Green, etc. Non-poisonous to human life. Price: 1 lb. canister, 15c; 5-lb. pkgs., 35c; 10-lb. pkgs., 65c; 100-lb. lots at 51/2c per lb. Panphlet containing full information mailed free.

GRASSELLI'S SULPHATE OF NICOTINE

An economical and powerful nicotine extract. One part to 600 of water is sufficiently strong to kill all insects, except scale, for which use 1 to 400 . The most effective remedy against aphis and fly insects. $1 / 4$-lb. can, 60c; 1 lb., $\$ 1.50 ; 2$ lbs., $\$ 2.75 ; 10$ lbs., $\$ 10.50$.

\section{GRASSELLI'S FREE NICOTINE}

One of the best compounds on the market; contains 40 per cent nicotine. 1/4-lb. can, 60c; 1/2-lo. can, $\$ 1.20 ; 1$-lb. can, $\$ 2.25 ; 8$-lb. can. $\$ 10.50$

\section{RAT CORN}

Sure death to rats and mice; not poisonous to other animals. 25c, 50c and $\$ 1.00$ size cans.

\section{CONKEY'S FLY KNOCKER}

One of the best sprays for protection of cattle, horses and stock against flies, gnats and other insects. It is not injurious to the hair. Very effective and remains on the animal as a preventative a long time. 1 qt., 35c; 1/2 gal., 60c; gal., $\$ 1.00$.

\section{NOXICIDE}

A soluble disinfectant, deodorant and germ destroyer : to be mixed with water and sprayed; for preventing mites, lice, cholera, poultry and stock diseases. It is to be used in poultry houses, horse stalls, and can also be used on the animal. Full directions on every can. 1 pt. size, 35c; qt., 60c.

\section{TREE TANGLEFOOT}

For protecting trees against climbing insect pests in a simple, economical and effective way; put a band of tree tanglefoot, from 3 to 5 inches wide, completely around the tree. A perfect safeguard against Gypsy, Brown-Tail and Tussock Moth, Canker Worms and Ants, and other creeping insects. 1 lb., 30c ; 3 lbs., 85c; 10 lbs., $\$ 2.65 ; 20$ lbs., $\$ 4.80 ; 25$ lbs., $\$ 6.00$.

\section{WEED KILLER (Traget Brand)}

A highly concentrated solution which dilutes one part to 50 parts of water. It is effective within 12 hours after application, and one application will keep paths and roadways free from weeds for an entire season. 1 qt., 40c; 1 gal., $\$ 1.00 ; 5$ gal., $\$ 4.00 ; 10$ gal., \$7.50.

WAX (Grafting)

$1 / 4$ lb., 10c; 1/2 lb., 15c; 1 lb., 25c. (By mail add 10c per lb.

\section{FERTILIZERS, PLANT-FOOD, ETC.}

BONE MEAL

Our Bone Meal is evenly ground and especially adapted for drilling. For lawn use, $10 \mathrm{lbs}$. for 250 square feet. Price-10 lbs., 40c; 25. lbs., 75c; 50 lbs., $\$ 1.25 ; 125$ lbs., $\$ 2.60$.

\section{SHEEP MANURE (Pulverized)}

A pure, natural manure, and very nutritious for plants. For potting soil, mix one part manure to six parts soil. For vegetable garden, place directly in hills or drills. Promotes a rapid, steady growth until maturity Splendid top dressing for lawns. 5 lbs. 25 c; 10 lbs., 40c; 50 lbs., $\$ 1.25 ; 100$ lbs., \$2.00.

\section{BLATCHFORD'S PLANT GROWER}

Odorless, highly concentrated, soluble food for house plants. Directions for using with each box. 11/2-lb. box, $25 \mathrm{c}$.

\section{LAWN FERTILIZER}

Old and new lawns. New require stimulating after the Winter, or in the Fall after the season of cutting and heat of Summer. For this purpose we recommend Wood Ashes, Sheep Manure or Bone Meal as being best adapted to the wants of the lawn. 


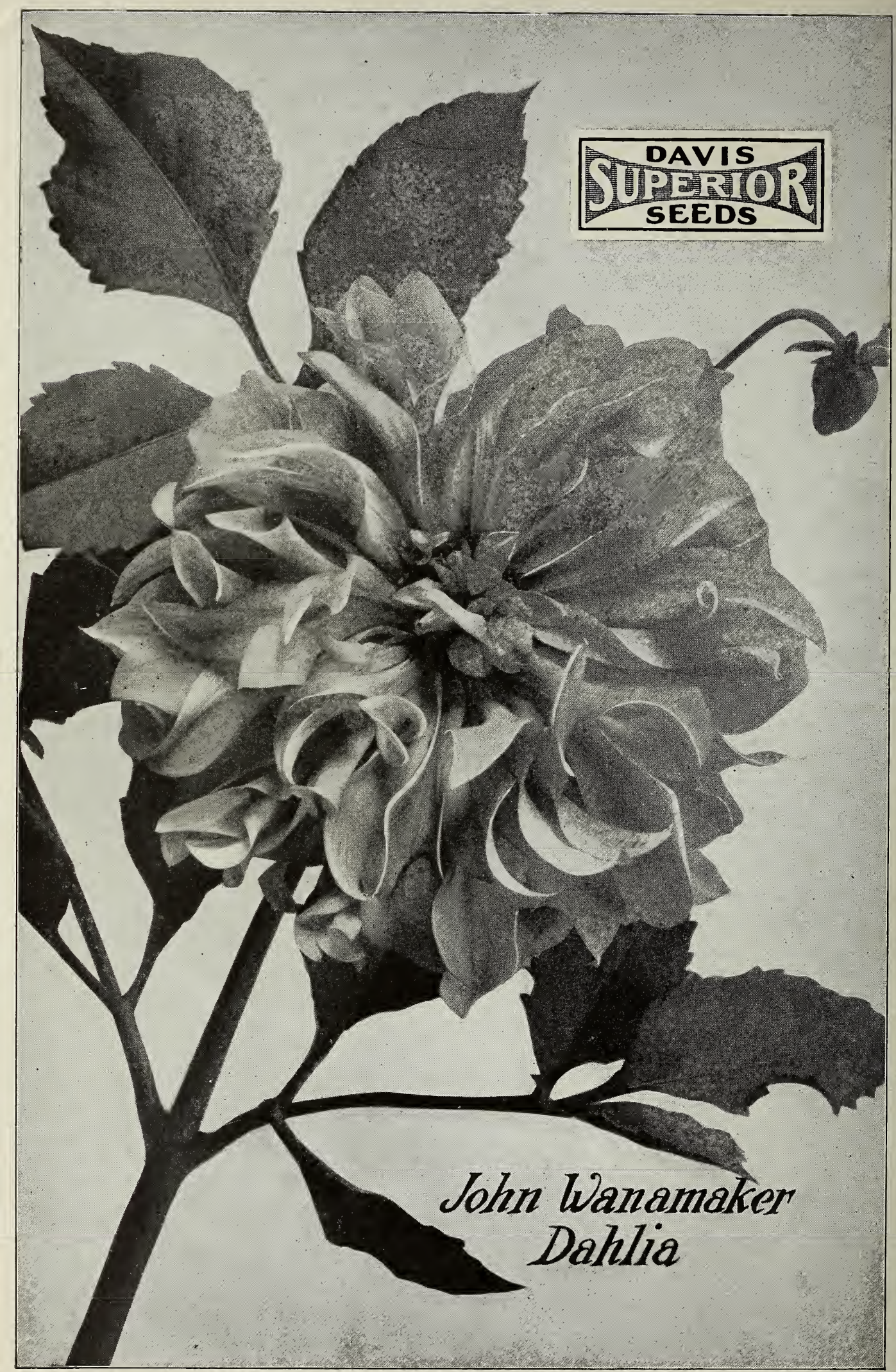

